\title{
Em torno de Hilda Hilst
}

\author{
Nilze Maria de Azeredo Reguera \\ Susanna Busato
}

(Orgs.)

REGUERA, NMA., and BUSATO, S., orgs. Em torno de Hilda Hilst [online]. São Paulo: Editora UNESP, 2015, 250 p. ISBN 978-85-68334-69-0. Available from SciELO Books $<\underline{\text { http://books.scielo.org }>\text {. }}$

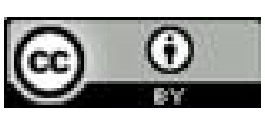

All the contents of this work, except where otherwise noted, is licensed under a Creative Commons Attribution 4.0 International license.

Todo o conteúdo deste trabalho, exceto quando houver ressalva, é publicado sob a licença Creative Commons Atribição 4.0.

Todo el contenido de esta obra, excepto donde se indique lo contrario, está bajo licencia de la licencia Creative Commons $\underline{\text { Reconocimento 4.0. }}$ 


\section{EM TORNO DE Hilda Hilst}




\title{
FUNDAÇÃO EDITORA DA UNESP
}

\author{
Presidente do Conselho Curador \\ Mário Sérgio Vasconcelos \\ Diretor-Presidente \\ Jézio Hernani Bomfim Gutierre \\ Editor-Executivo \\ Tulio Y. Kawata
}

Superintendente Administrativo e Financeiro

William de Souza Agostinho

Conselho Editorial Acadêmico

Áureo Busetto

Carlos Magno Castelo Branco Fortaleza

Elisabete Maniglia

Henrique Nunes de Oliveira

João Francisco Galera Monico

José Leonardo do Nascimento

Lourenço Chacon Jurado Filho

Maria de Lourdes Ortiz Gandini Baldan

Paula da Cruz Landim

Rogério Rosenfeld

Editores-Assistentes

Anderson Nobara

Jorge Pereira Filho

Leandro Rodrigues 


\section{NILZE MARIA DE AZEREDO REGUERA SUSANNA BUSATO (Orgs.)}

\section{EM TORNO DE Hilda Hilst}


Direitos de publicação reservados à:

Fundação Editora da Unesp (FEU)

\author{
Praça da Sé, 108 \\ 01001-900 - São Paulo - SP \\ Tel.: (0xx11) 3242-7171 \\ Fax: (0xx11) 3242-7172 \\ www.editoraunesp.com.br \\ www.livrariaunesp.com.br \\ feu@editora.unesp.br
}

CIP - Brasil. Catalogação na publicação

Sindicato Nacional dos Editores de Livros, RJ

\title{
E44
}

Em torno de Hilda Hilst [recurso eletrônico] / organização Nilze Maria de Azeredo Reguera, Susanna Busato. - 1.ed. - São Paulo: Editora Unesp Digital, 2015.

Recurso digital

Formato: ePub

Requisitos do sistema: Adobe Digital Editions

Modo de acesso: World Wide Web

ISBN 978-85-68334-69-0 (recurso eletrônico)

1. Hilst, Hilda, 1930-2004 - Crítica e interpretação. 2. Livros eletrônicos. I. Reguera, Nilze Maria de Azeredo. II. Busato, Susanna.

Este livro é publicado pelo projeto Edição de Textos de Docentes e Pós-Graduados da UNESP - Pró-Reitoria de Pós-Graduação da UNESP (PROPG) / Fundação Editora da Unesp (FEU)

Editora afiliada:

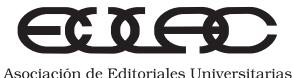
Asociación de Editoriales Universitarias de América Latina y el Caribe

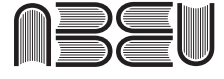

Associação Brasileira de Editoras Universitárias 
À Maria Laura.

A todas as mulheres que ousam encarar o mundo com a lucidez do corpo. $E$ a todas que ainda não conhecem os prazeres da palavra ousadia. Este livro é um roteiro. 


\section{SUMÁRIO}

Apresentação-Quem tem medo de Hilda Hilst? 9 Susanna Busato

Hilda menor: teatro e crônica 13 Alcir Pécora

A eminência da morte na dramaturgia de Hilda Hilst:

A possessa e O Verdugo 29 Éder Rodrigues e Sara Rojo

De Oswald de Andrade a Hilda Hilst: o lúdico na literatura brasileira do último século 49 Nilze Maria de Azeredo Reguera

Refulgência, dor e maravilha. Os conceitos de tempo, deterioração, finitude e morte na obra de hilda hilst 75 Alva Martínez Teixeiro

Hilda Hilst: "Respirei teu mundo movediço" 99 Ana Chiara

Aquelas coisas e um pouco mais: a erótica senil 115 Eliane Robert Moraes

Sexualidade e riso: a trilogia obscena de Hilda Hilst 121

Mechthild Blumberg 
8 NILZE MARIA DE AZEREDO REGUERA • SUSANNA BUSATO (ORGS.)

Falando com Deus... 139

Michel Riaudel

Os autorretratos na lírica de Hilda Hilst 155

Elaine Cristina Cintra

Os ofícios do sacro em Poemas malditos, gozosos

e devotos de Hilda Hilst 177

Higor Sampaio

Traduzir as faces de Deus 205

Hsiao-Shih Lee

"I'm coming out in English": em torno da tradução

de Contos d'escárnio. Textos grotescos 229

Julia Powers e Livia Drummond

Sobre os autores 245 


\section{ApresentaÇÃo \\ Quem tem Medo de HiLda HiLst?}

O dado de provocação desta pergunta ainda se faz presente, passados dez anos de sua morte (1930-2004). A escritora, poeta e teatróloga, nascida em Jaú, São Paulo, ganha nestes últimos tempos uma nova leitura e um interesse crescente por sua obra. Teria escrito para quem? Queixava-se desde os anos 1970 da falta de leitores de seus textos. Teria Hilda Hilst escrito para os leitores de nossa época? Leitores curiosos e abertos aos temas de sua estranha forma? Leitores que não mais se enrubescem ante os despudores de seus personagens? O fato é que há leitores que não têm medo de percorrer o impasse que a literatura oferece no seu insistente renascer de formas e temas. Os que enfrentam o jogo fornecido pela escritora absorvem e revolvem esse universo do sacro e metafísico, do erótico e pornográfico, do combativo discurso político e social, do amoroso e sublime desejo da morte.

Em torno de Hilda Hilst é um livro que se situa no panorama da leitura atenta, sensível e curiosa da obra da autora. Reunimos aqui pesquisadores da obra de Hilda Hilst, do Brasil e do exterior, amantes dessa chama inquieta que é o texto literário que a escritora paulista tão bem soube manter quente e acesa ao longo dos quarenta e sete anos de trabalho exclusivo com a literatura. Vários olhares e vários enfoques acendem a chama da palavra em lança, em jogo 
perpétuo com a linguagem, com o objetivo único de descobrir como se encena a performance do discurso da obra de Hilda, que, no seu trajeto tenso e violento, sublime e erótico, desafia tanto os trabalhos de tradução, como os trabalhos críticos que se submetem aos interstícios de sua linguagem.

Lembremo-nos aqui do primeiro poema de Prelúdios - intensos para os desmemoriados do amor. Hilda Hilst, nesse poema, oferece-nos um corpo. Um corpo de desejos e procuras. De dentro dele, do poema-corpo, emerge uma voz que convida: "Toma-me". E o poema se entrega como num jogo de sensações e trocas: "toma-me / Crava a tua mão, respira meu sopro, deglute / Em cadência minha escura agonia”. Mas “enquanto caminhas / Em lúcida altivez, eu já sou o passado. [...] / Passeia / Sobre mim, amor, e colhe o que me resta: / Noturno girassol. Rama secreta”.

Passeamos. Tateamos esse corpo. De dentro e no entorno. E eis que o livro nasce a tantas mãos e tantos olhares e vozes. Nasce com um desejo, o de descobrir a persona ou as várias personas que habitam a lírica de Hilda Hilst. E, ainda, nasce com o desejo de explorar na linguagem de sua narrativa esse lado do obsceno e do inviolável, da ironia e do escracho, do erudito e do popular que tão bem soube articular como um repertório cultural rico para sua obra.

Os capítulos a que o leitor se lançará a partir daqui procuram situar-se na obra de Hilda Hilst a partir de um ponto de vista estratégico. O objetivo de cada um é de levar o leitor a, conjuntamente com os autores, perscrutar o olhar crítico que desenha as formas do texto hilstiano, no seu ondular dramático e erótico do discurso, presente na sua produção tanto teatral quanto narrativa; na natureza vitimológica de sua poesia lírica e suas entranhas discursivas que se desdobram e se exploram intertextualmente. Até suas crônicas são objeto de leitura, evidenciando nelas o lado humorístico que tão bem Hilda Hilst soube cultivar. Nada nela era para ser levado a sério. Ou antes, tudo era feito dentro da seriedade com que a literatura se busca num incessante renascer de si mesma, pelo esgotamento que logo percebe em suas rotas. 
As vozes que o leitor ouvirá serão múltiplas, cada uma explorando o diapasão acústico das demais vozes que emergem dos Contos d'escárnio, por exemplo, no desafio que impõem à sua tradução para o inglês. Como compreender os caracteres chineses que acompanham os poemas de Sobre a tua grande face, como traduzi-los na sua presença visual concisa contrastada com o verbal solene dos versos?

Outro percurso na obra de Hilda Hilst é de suas intestinações, seus espaços de gruta e intimidade lodosa, onde o grotesco e o patético emergem numa linguagem sem pudores. Um modo de ser do sujeito do discurso que revela o humano sob a pele do bicho que habita o homem. Um modo de ser que se revela na linguagem e na cena aberta. O gesto sacrificial e maldito é objeto dos capítulos que se lançam nas sendas desse elemento noturno e místico, mas tão verdadeiramente sincero na sua projeção lírica que qualquer leitor de Hilda Hilst se vê à mercê de sua palavra. Assim são as análises que se inserem no corpo de Fluxo-floema, nos interstícios de Poemas malditos, gozosos e devotos, nos mistérios que envolvem a morte e a dimensão orgiástica da vida, o erotismo e a libidinagem, em textos como $O$ caderno rosa de Lori Lamby, A obscena senhora $D$ e Da morte. Odes mínimas, por exemplo.

O erotismo na obra de Hilda Hilst não se oferece somente nas referências ao corpo ou nas intenções do enunciador do discurso, ou no jogo enunciativo com a figura de um deus para quem se lança como desejo, como escravo, como dominador. O erotismo na obra de Hilda Hilst habita a linguagem, no seu jogo linguístico, quase carnal com a palavra que vai se despindo e se experimentando, sendo autorreferencializada pelo discurso. Difícil separar essa carga erótica do próprio percurso poético da palavra em sua obra. Provavelmente é ela que, sub-repticiamente, habita o tom elevado e sublime com que sua lírica invade os versos de Da morte. Odes mínimas ou dos versos de Poemas malditos, gozosos e devotos. Há em Hilda Hilst uma premência por atingir um alvo sublime, que se deposita num horizonte mítico. Sua palavra, no conjunto de sua obra, carrega esse work in progress, ou seja, um roteiro poético que 
vai desreferencializando os signos que aponta, nomeando-os de formas diferentes, exponenciando-os como figuras.

Que o leitor se entenda nessas sendas. Que o leitor mesmo se enlace e se desenlace e que se lance à leitura dos roteiros que por ora se oferecem à descoberta dos espaços percorridos pela linguagem pela autora brasileira. A literatura é um mal. Opera aos poucos uma metamorfose. Na mente. Na linguagem. No cotidiano das palavras. Acentua os limites. Enfatiza os horizontes. Organiza o caos. Demoniza. E pergunta com a ingenuidade dos que não sabem e têm fome pela voz de uma de suas personagens - América - na peça $A$ possessa: "Eu digo as coisas que penso. Só isso. Se elas são más não sei. Muitas vezes eu nem sei quem sou. Mas penso que não há mal nenhum em perguntar o que não se entende. [...] Assim é que começam as coisas. Com as perguntas".

Em torno de Hilda Hilst também pergunta. E ousa responder. Mas está no gesto da ousadia toda a fortuna da vida. Mais uma lição que a escritora, poeta e dramaturga soube ensinar em sua vida dedicada à literatura. Este livro é a tarefa e o aprendizado. Que o leitor desfrute sem limite.

Susanna Busato 


\section{HILDA MENOR: TEATRO E CRÔNICA ${ }^{1}$}

Alcir Pécora

Se há uma disputa que mexe com os nervos entre os leitores de Hilda Hilst é saber se ela é mais poeta ou mais prosadora, ou, de outra maneira, se foi mais longe literariamente na poesia ou na prosa de ficção. Por outro lado, pouca atenção tem sido dada até agora, mesmo pelos seus mais fiéis leitores, aos textos que produziu em dois outros gêneros, aparentemente mais frutos de ocasião em sua escrita do que de engajamento sistemático e consequente. Falo naturalmente do teatro e da crônica.

Em relação à crônica, o desinteresse parece até mais compreensível: Hilda se limitou a escrever para um único jornal, de circulação apenas regional, durante um período bem determinado (19921995). A publicação em livro desse material apenas aconteceu, e ainda parcialmente, em 1998, por iniciativa da editora Nankin, de São Paulo. O conjunto delas só foi editado em 2007, pela editora Globo. A rigor, portanto, sua circulação ampla é muito recente.

No que toca ao teatro, parte da história é semelhante: suas oito peças também foram escritas num período bem determinado, mais

1 Uma primeira versão deste texto foi publicada como "O limbo de Hilda Hilst: teatro e crônica”, Revista da Biblioteca Mário de Andrade, v.69, p.130-47, jan. 2015. 
precisamente de 1967 a 1969. À exceção da única peça mais conhecida, $O$ verdugo, todo o material ficou inédito em livro até 2000, quando foram lançadas quatro das peças pela editora Nankin. A edição do conjunto integral das peças novamente ocorreu apenas na edição da Globo, em 2008.

Há diferenças, contudo: o teatro de Hilda foi escrito num período em que era ele o gênero que mais contundentemente catalisava a produção e a recepção cultural de época. Ele poderia ter ficado conhecido e ter sido muito mais montado e debatido do que realmente foi. Nada mais diverso do que se dá com a crônica, cujo lugar cultural, tanto no jornal como no cenário literário brasileiro sempre foi secundário. Mesmo Rubem Braga, o mais celebrado dos cronistas brasileiros do século XX, ressentia-se dessa situação de relativo desdém pelo gênero, mesmo que em geral o negasse.

Além disso, há um dado bem curioso e importante a ser anotado aqui. Conquanto o teatro propriamente dito de Hilda Hilst esteja praticamente esquecido, a dramaturgia sobre a sua obra em prosa não teatral cresce sistematicamente! E, a julgar pela volúpia com que jovens dramaturgos têm se lançado sobre sua prosa, esse crescimento promete ser muito maior. É como se o teatro de Hilda apenas alcançasse o seu ponto de realização na prosa e como se o que produziu diretamente como teatro não chegasse lá.

Para entender esse fenômeno do apelo teatral de seus textos em prosa, é preciso mergulhar na leitura deles e perceber o quanto seu processo de composição mais nuclear, a saber, o fluxo de consciência, recebe um tratamento marcadamente dramático que tem menos a ver com uma personagem ensimesmada, cujos pensamentos vão se construindo ou improvisando mentalmente, que com uma geração contínua de personagens que se desdobram em confronto contínuo.

Além disso, tais confrontos de personagens proliferantes se dão no âmbito de cenários econômicos e sistemáticos, quase abstratos, o que os afasta bastante da representação realista. Já comentei esse aspecto dramático da literatura de Hilda em outros textos, mas, melhor do que eu o fiz, procurou evidenciá-lo a tese de doutoramento 
de Sonia Purceno, ainda inédita em livro, mas passível de ser acessada on line na Biblioteca da Unicamp. A tese convincentemente demonstra a existência em Fluxo-floema, O caderno rosa de Lori Lamby e em outros textos de ficção, do forte movimento dialógico do fluxo, sustentado por personagens antagônicos e cenários compostos de recintos confinados, mas invariavelmente com escapes estreitos para cima e para baixo.

Ou seja, a dramaturgia de Hilda tem se alimentado de sua ficção, mas sua dramaturgia propriamente dita, como disse antes, permanece num limbo tão obscuro como o de suas crônicas. Proponho-me aqui a fazer um breve passeio por esses dois gêneros e esboçar o que neles funciona mais - ou menos.

\section{Teatro}

Hilda compôs oito peças, entre 1967 a 1969. Como disse, trata-se de um período no qual o teatro - e, em especial, o teatro universitário - adquire grande importância, tanto por sua significação nacional de resistência contra a ditadura militar como pela vigorosa consonância com as manifestações políticas e artísticas que ganham corpo em todo o mundo ocidental.

Ao escrever todas as suas peças nesses pouco mais de dois anos exuberantes, Hilda Hilst dava mostras de entender o apelo único que o teatro representava naquele momento. Pode-se dizer que foi uma produção de ocasião, mas não uma produção oportunista, pois estavam e estão lá os problemas que se tornariam centrais em sua obra em prosa, que então mal começava a existir.

Ou seja, de certo ponto de vista, o efeito mais importante de seu teatro foi o de ensaiar a sua prosa. Poder-se-ia pensar que, em relação à poesia, o teatro não teve efeito significativo, pois esta, como se sabe, Hilda produzia havia mais de uma década, já tendo obtido várias resenhas favoráveis de críticos importantes. No entanto, não é assim. A própria poesia de Hilda nunca foi a mesma depois da experiência de dramaturga e de sua iniciação na prosa. 
O salto de qualidade é evidente, como vários críticos já apontaram e eu mesmo já tentei demonstrar em notas à edição de Júbilo, memória, noviciado da paixão, livro de 1974 que inaugura uma fase muito mais complexa em sua poesia. A dicção poética alta, de inspiração parnasiana, que até então parecia predominar em sua poesia, ganhou contrapontos surpreendentes de humor, de registro vulgar e de vivacidade dialógica que lhe deram muito mais alcance estilístico e intensidade de fatura.

Desse modo, se o teatro de Hilda Hilst parece servir mais à prosa e à poesia do que a si mesmo, por ser episódico, pode-se pensar que, em termos de dramaturgia, ele se resumiria a uma coleta de lugares comuns do teatro militante de época. Até certo ponto, não é uma impressão falsa: trata-se de um teatro alegorizante, de feitio genericamente didático ou doutrinário, cujo assunto básico gira em torno de uma situação de opressão institucional. O Exército, a Igreja, o Tribunal, a Empresa, a Escola ou outra instituição exerciam seu programa repressor, aplicando-o contra a população e contra os heróis, perfeitamente distintivos, insubmissos e dispostos a se sacrificar por uma ordem mais justa.

Acontece que Hilda, sem deixar de constituir suas peças próximo a esses lugares comuns de época, também introduz variantes notáveis no desenvolvimento deles, nem sempre simpáticos às correntes dominantes nos pensamentos da esquerda. A começar pelo fato de que a instituição autoritária tematizada por Hilda é especialmente vigilante contra os mais talentosos e estranhos, isto é, personagens que se caracterizam como representantes de uma comunidade, mas também como seres de exceção, muito diversos de todos.

São estes os que mais recebem a admiração da jovem teatróloga, e não o homem comum ou a coletividade em geral. Isso não torna melhor ou mais aguda a simbologia de que lança mão nas peças, mas diversifica o uso que ela faz de uma simbologia que ela mesmo já reconhece como inexoravelmente "gasta", sem, contudo, abdicar dela.

Dou um exemplo bem recorrente em todas as peças. Insiste-se numa imagem dos protagonistas como seres "com asas". Elas sig- 
nificam o óbvio: apontam o sujeito inconformado, criativo, único, que acaba pagando o preço de sê-lo em meio à autoridade repressora, de um lado, e à gente comum, que reproduz embaixo o anódino institucional de cima.

Entretanto, de modo geral é possível dizer que Hilda submeteu os lugares comuns da época à sua própria maneira de encará-los, fazendo a aporia e a contradição ocuparem o lugar central de todas as suas peças. Evidentemente, esses pontos de desequilíbrio dos estereótipos são o que me interessa ressaltar aqui - para, quem sabe, entusiasmar outros leitores, mais apetrechados para retirar as peças do vazio interpretativo em que se encontram.

No caso de A empresa (ou A possessa), de 1967, a nota hilstiana mais interessante não é, como se poderia esperar, a denúncia da repressão institucional sobre os jovens, mas o alerta sobre a possibilidade terrível de que justamente os jovens mais criativos possam ser cooptados ou ter sua imaginação posta a serviço do processo repressivo. Quando a personagem "América" inventa "Eta" e "Dzeta", supondo demonstrar a fecundidade de sua imaginação e, portanto, sua diferença em relação aos padrões anódinos da instituição, o que ela acaba involuntariamente fazendo é prover a instituição repressora de recursos muito mais eficazes que aqueles de que ela dispunha até então.

Revela-se aqui um tema que sempre esteve no coração da obra de Hilda: a existência de uma condição destrutiva no cerne da mais genuína criação, a qual tanto se abate sobre seu criador quanto se mostra impotente diante de sua manipulação autoritária. Essa contradição entre invenção e liberdade é o que há de melhor na peça, e, nisso, Hilda se aproxima curiosamente de um autor como George Orwell, cujo 1984, por exemplo, sugeria que nenhuma ação repressora de desintegração da vontade pessoal atingia seu grau máximo antes da colaboração de um intelectual criativo.

Em $O$ rato no muro, do mesmo ano, a melhor nota hilstiana, ou seja, aquela que desafina o estereótipo adotado, está na imagem baixa do "rato" para caracterizar o único ser que, tendo agilidade para subir no muro, capacitava-se para ver além dos processos edi- 
ficantes da reeducação social e cívica. Outra vez, o que se põe fora da estreiteza institucional é marcado por algum estigma, aqui acentuado por um clima neogótico, penetrado por lembranças vagas, interditos, mal-entendidos, conversas exasperadamente cifradas. O efeito geral é de desarranjo assombrado que vai se instalando em meio a uma situação de histeria coletiva.

O Visitante, de 1968, é a peça mais distinta do conjunto dramático produzido por Hilda Hilst. Para um leitor familiarizado com sua obra, é fácil reconhecer que ela contém o núcleo narrativo da segunda parte da novela Tu não te moves de Ti, que apenas será publicada doze anos depois. Na peça, Hilda compõe um núcleo familiar que nada tem de prosaico; ao contrário, evoca a lembrança de alguma fantasia literária imemorial, com vagos elementos de paganismo popular. Parece celebrar a alegria e a força generativa da vida, mas acaba também por pressagiar o engano, a traição e a dor que parecem residir, inalienáveis, no fundo de toda relação amorosa.

Além da vinculação mais direta com a prosa posterior de Hilda, a peça se distingue do conjunto teatral pelo seu viés erótico e intimista, distante, portanto, da situação de repressão institucional constante no restante de seu teatro. No entanto, a peça está igualmente distante de uma situação pacificada. A cena idílica inicial logo se revela como fonte de suspeitas, acusações e situações torturadas. Seu andamento, centrado num triângulo composto de mãe-filha-genro, efetua uma via tortuosa que arruína a ideia de confiança entre os que se amam.

O Auto da barca de Camiri, também de 1968, tem como pano de fundo a morte de Ernesto "Che" Guevara. O próprio título já o evidencia, já que Camiri é o nome da região da Bolívia onde "Che" teria sido morto em outubro do ano anterior. No entanto, na peça, o nome do guerrilheiro jamais é revelado, sendo referido apenas como "homem", o que certamente tem a ver com a censura de época, mas também com os próprios propósitos alegóricos que a autora pretendeu extrair do episódio.

A cena é de um julgamento das ações do tal "homem". As testemunhas da defesa são figuras igualmente alegóricas, que não 
recebem nomes próprios, mas são designadas pelo ofício: o "Passarinheiro" e o "Trapezista". Tais ofícios, percebe-se facilmente, estão no domínio do "ar" ou das "asas", o que traz novamente para a cena a simbologia operacional "gasta" a que me referi antes, que Hilda acolhe, mas também obscurece. Também está óbvio que o "Che" by Hilda tem muito de Cristo: é ele o cordeiro sacrificial imolado com sentido expiatório para salvação do conjunto dos homens.

No entanto, a salvação é uma possibilidade adiada e o Cristo revolucionário é um sujeito ausente. $\mathrm{O}$ "homem" é julgado in absentia e os atos que lhe atribuem, se o caracterizam como um Cristo solitário, incompreendido, também o esboçam como um ente exclusivamente aludido, não como quem pode tomar para a si a palavra. Nisto, curiosamente, lembra mais um herói maldito de romance epistolar gótico, cuja presença nunca se dá diretamente ao leitor, mas é apenas referida por outros. Antes de ser corpo vivo que pode ou não ser condenado à morte, já surge na forma de um morto que continua a assombrar os vivos.

O efeito abertamente cômico dos diálogos e interrogatórios feitos pelos juízes remete a Kafka, ainda mais quando a conversa mergulha em paroxismos de incompreensão e de interferências deslocadas do assunto principal. A deriva aleatória do julgamento parece demonstrar o nonsense do Direito sustentado pelos juízes, e, ainda, sua impossibilidade de lidar com a realidade que ocorre fora do palco - desta, apenas se ouvem as rajadas sucessivas de metralhadora e os gritos dos executados. No fundo, os juízes que o condenam, bem como o "homem" que é acusado, fazem parte de espaços que não se cruzam e que, até certo ponto, permanecem intocáveis entre si.

Notemos também que o termo "auto" é explorado na peça em sentido equívoco, significando tanto o material processual como a encenação de assunto sacro, pois o processo que condena o "homem" também acaba atestando sua natureza sagrada. A personagem do "prelado" reforça esse aspecto. Tomada de modo favorável, é a única que pode entender e confirmar que a realidade vivida 
pelo "homem" é um anúncio de vida futura, enquanto o julgamento está encerrado em seu próprio impulso de repressão e morte.

As aves da noite, ainda de 1968, segue de perto a peça anterior, dramatizando um episódio real da morte de um herói entendido como mártir da liberdade. Desta vez, a ação é inspirada nos eventos protagonizados pelo Padre Maximilian Kolbe, morto em 1941 em Auschwitz, ao se apresentar voluntariamente para ocupar o lugar de outro prisioneiro sorteado para morrer de fome como punição por uma suposta fuga ocorrida no campo. Em 1971, a Igreja Católica beatificou o Padre Kolbe; em 1982, ele foi canonizado por João Paulo II e, desde então, costuma ser designado como santo protetor de presos políticos, jornalistas e outras profissões ligadas à liberdade de expressão.

Hilda está particularmente interessada em considerar o herói posto em situações extremas, nas quais dá testemunho de uma convicção moral e religiosa inabalável e explicável, quando nada no mundo oferece qualquer fiança para a verdade da crença e, ao contrário, parece dar testemunho de seu completo vazio.

Outro ponto relevante a considerar na peça é a apologia que faz da aceitação do sofrimento próprio e do reconhecimento da humanidade mesmo do mais cruel inimigo, ao qual não se nega a aplicação da metáfora "gasta": são "aves", embora noturnas. Contra essa ideia de compaixão sem limites não está a razão ou a justiça, mas o rancor autodestrutivo dos que se debatem inutilmente contra a fragilidade da vida e o horror habitual do destino. Ou seja, na encenação de confrontos de atitudes entre os prisioneiros diante da morte, a admiração de Hilda vai para os que voluntariamente escolhem o fim que lhes é dado, de tal modo que nessa escolha da morte e da não violência reside paradoxalmente toda a esperança humana de sobreviver à barbárie.

Pode-se dizer que a posição de Hilda é próxima à de Ghandi, popularizada nos movimentos contraculturais dos anos 1960, mas há nela também um acento cristológico de afirmação sacrificial no tempo presente. A entrega voluntária à crueldade do outro é o único gesto eficaz contra a ação violenta, seja a do carrasco, movida 
pela pulsão de morte, seja a do próprio prisioneiro, conduzida pela vingança da injustiça sofrida. A ideia que parece defender é a de que nada, no futuro, poderá resgatar teleologicamente o crime que se comete no presente. Nenhum mundo novo, nobre e justo aguarda ao fim do pesadelo. O mundo é este e a nobreza, quando houver, há de ser manifesta já.

O novo sistema, última das peças de 1968, novamente traz à cena as alegorias do autoritarismo presentes nas demais peças, com uma variante: é a ciência que, agora, fornece o paradigma da ação institucional repressiva. A peça é uma ficção futurista à maneira de 1984 ou de Admirável mundo novo, com a particularidade de que, nela, a Física se torna a fonte subsidiária do Direito e, portanto, de legitimação científica do poder tirânico. $\mathrm{O}$ double think orwelliano se torna, na peça, uma espécie de mote didatizante. Cada gesto autoritário introduz o mantra da ciência positiva: "estude física".

Aqui emergem dois elementos importantes de dissonância dos clichês típicos dessa compreensão da ciência como novo totalitarismo. O primeiro diz respeito ao fato de que os maiores talentos não estão necessariamente a serviço do bem - antes, são lugares em que o bem e o mal se encontram como potência. Segundo, na esfera coletiva predomina uma subalternidade estúpida, da qual nada se pode esperar a não ser a servidão voluntária a qualquer senhor.

Em termos políticos, a vontade coletiva é sempre menos decisiva do que a escolha individual, não partilhada, mas significativa porque torna existente no presente a potência de humanidade que reside no indivíduo. O corolário dessa posição é a clara descrença num futuro forjado por uma doutrina revolucionária, que apenas poderia resultar numa nova forma de tirania, ainda pior ou mais cruel, pois mais convicta de suas bases sociais e científicas.

O verdugo, de 1969, é a peça mais representada de Hilda e também a única que chegou a ser premiada e publicada em seu tempo. Repete-se o esquema de julgamento já presente no Auto da barca de Camiri e não é difícil sustentar que novamente o "homem" em julgamento é o "Che", cujas características cristológicas são acentuadas pelo caráter de parábola de seu discurso. Por falar por pará- 
bolas, a questão da interpretação passa a ocupar o primeiro plano do drama, o que, no caso, implica a tentativa de compreender o paradoxo da luta armada - e, portanto, da violência -, num projeto cuja destinação final é a relação amorosa entre os homens.

A resposta aventada pela peça contempla dois movimentos distintos: primeiro, deixa clara a venalidade das gentes, que não hesitam em sacrificar o "homem" que fala por elas, ou em nome de um futuro para elas, em troca de dinheiro e vantagens imediatas. Nisso, a cena do julgamento de rua retoma diretamente a do julgamento do Cristo por Pilatos. Segundo, ensaia-se uma justificativa para as grandes "patas de lobo" desenvolvidas pelos "homens-coiotes", como são chamados os que resistem à execução da pena injusta aplicada pelos juízes. É como se, diante da arbitrariedade tirânica, apenas a violência dessas "patas" agisse em favor da instauração da justiça, ou, ao menos, de uma etapa de sua efetuação progressiva.

Entretanto, mesmo nesse ponto de relativa justificação da violência, mais uma vez a peça evidencia a impotência da revolta, pois os "homens-coiotes" apenas assistem, sem conseguir reagir, à execução de seu líder. Assim, se O verdugo acentua a feição cristológica do líder revolucionário, que padece a morte pelo bem dos que o vendem, também reforça uma tradição de leitura revolucionária do Cristo, como fazia Pasolini, em 1964, com seu O Evangelho segundo São Mateus, o que tende a justificar ou entender a necessidade da violência na luta pelo direito.

A última peça de Hilda, A morte do patriarca, ainda de 1969, retoma a encenação em ambientes confinados e quase sem ação, a não ser de ordem subjetiva e intelectual. No palco, as imagens de Cristo, de líderes revolucionários, além de um surpreendente Ulisses, são exibidas como forma de atrair e manipular a simpatia de um grupo de jovens revolucionários prestes a tomar o palácio papal. Cristo, ainda mais que Ulisses, é objeto da simpatia da autora (ao contrário de Marx, Lênin ou Mao), mas nenhum deles consegue blindar a Igreja quando eclode a revolta popular contra sua autoridade.

Assim resumida a ação, a peça pode parecer um passo adiante de $O$ verdugo na aceitação da violência revolucionária. Não é o caso: 
os jovens que invadem o palácio e matam o papa o fazem sob os incentivos do mesmíssimo conselheiro do papa que cai: o demônio. A iconoclastia dos jovens traz em si a origem do mal que produziu, no passado, a ascensão da própria Igreja. Deus e os anjos apenas observam, sem intervir, possivelmente antevendo o desgraçado fim da história. O mais notável no andamento da peça, entretanto, é menos o seu desfecho cético que o humor anárquico que se desenvolve em meio às cenas mais dramáticas, produzindo diálogos agudos e ágeis, o que será marcante na prosa posterior de Hilda.

Isso é o que me ocorre dizer como apresentação sucinta do teatro de Hilda Hilst. São peças que praticamente não tiveram encenação profissional, a não ser $O$ verdugo. Portanto, até agora não funcionaram como teatro propriamente dito, isto é, com personagens atuando em cena, diante do público. A falta de ação, o enredo abstrato, o acento colocado sobre a palavra poética, uma discussão política que mais parece condenar a política, um teatro popular que parece implacável com o povo, certo catolicismo padecente e vitimista que contamina o pacifismo, o repúdio às posições polarizadas da época, sem deixar de acentuar os polos; um olhar mais agudo para as contradições e as incongruências, mais que para a clareza ideológica qualquer coisa, ou tudo isso, resultou no fracasso de seu teatro.

Sempre que volto ao texto das peças, me pergunto se elas - que foram longamente desenvolvidas, de maneira mais complexa e radical na prosa de ficção de Hilda - teriam ainda chance de funcionar como teatro. E não tenho resposta para essa indagação. Os textos têm bons momentos, situações potencialmente fortes, uma vez que irrealizadas. Mas como saber o que vale um teatro que não é encenado? Se o fosse, imagino que demandaria fortes adaptações, já que as tópicas revolucionárias e as metáforas gastas com as quais dialoga, em larga medida, são já ruínas.

\section{Crônica}

Quando já tinha completado 60 anos, Hilda Hilst aceitou o convite para escrever uma coluna de crônicas para o recém-criado 
“Caderno C" do jornal diário Correio Popular, de Campinas, e o fez regularmente entre 30 de novembro de 1992 e 16 de julho de 1995. Sua coluna, que tinha como título apenas o nome da autora, começou a ser publicada às segundas-feiras, assim permanecendo até 20 de setembro de 1993. De 17 de outubro de 1993 até o final de sua colaboração, passou a circular aos domingos, sempre tendo como editor do caderno o jornalista Jary Mércio.

Às segundas ou aos domingos, a crônica de Hilda não passava desapercebida. Para alguns poucos, suponho que se tratava de razão suficiente para comprar o jornal; para outros, era motivo para os mais veementes protestos contra sua linguagem desbocada, à qual não faltava o calão; para muitos, era a chance de rir dos destrambelhamentos de uma velha louca.

Certo é que não havia meio de frear a liberdade da imaginação de Hilda Hilst pelo chamado à responsabilidade do senso comum. Lembro-me exemplarmente de uma crônica sua, a qual, edificante em seus próprios termos, animava velhinhas a se empenhar na prática do sexo oral, já que a falta de dentes, garantia a cronista, ajudava o trabalho de sopro. O tom metódico e didático do texto era hilariante. Deixava evidente que Hilda Hilst era uma humorista completa, no sentido pirandelliano do termo, isto é, alguém que não apenas sabe fazer entender o contrário do que diz, mas que suspende as certezas do que diz e do que insinua, voltando-se contra si mesmo e produzindo aporia e paradoxo. Esse mesmo exemplo da velha gulosa serve para mostrar que, para Hilda, nada era estranho ao humor, mesmo o tema difícil, senão doloroso, das misérias da velhice, que era talvez o mais constante do conjunto das crônicas.

Esse é apenas um exemplo, entre tantos outros, hilariantes e igualmente duros, que Hilda mandou ao jornal. Alguém ainda terá de falar com muita seriedade da Hilda Hilst humorista, e, quando fizer isso, será nas crônicas que encontrará alguns de seus melhores argumentos, mesmo que não exclusivamente nelas. No Brasil, que sempre se louva de muito engraçado, há poucos autores que praticam uma escrita de alto nível no qual o humor seja um componente tão decisivo. 
Estar sob o influxo do humor das crônicas de Hilda é, de alguma forma, estar implacavelmente exposto a um processo educativo, entendido como aprendizado de rir de si mesmo e de desistir de toda afetação vulgar, seja a de autoridade, seja a de intelectual sério, intérprete de grandes aspirações nacionais. O melhor jeito de se livrar do pior da sua ironia era aprender que não há sentido elevado possível que imediatamente não traga o contraponto de uma baixeza: a humanidade não está em nenhum deles sem que venha junto o outro.

Ler aquelas crônicas da primeira metade dos anos 1990, especialmente no que diz respeito à sua indignação contra a roubalheira generalizada do governo e a insensibilidade venal dos políticos, é ainda tão amargamente divertido como no tempo em que as escreveu. Quase digo que o que ela disse antes apenas agora se revela em toda a sua densidade e mau cheiro. Mas não era profecia, não, longe disso: o que hoje se passa é apenas continuidade cabal do mesmo merdel de "quinto mundo".

O Brasil sem-vergonha de Collor e PC Farias, dos anões do orçamento, das famigeradas "sobras" de campanha, da chacina da Candelária, da impunidade generalizada, da arrogância boçal dos ricos, que são sempre novos-ricos, da parvoíce do plebiscito da monarquia, das negociatas do FMI, do roubo da Previdência, da secular indústria da seca, da prostituição infantil, da privatização cavilosa... De tudo isso Hilda falava e ria, brava, e ainda estaria a esbravejar, rindo, pois novos e impensáveis descalabros públicos lhe cairiam nas linhas afiadas, como ainda se apresentam a nós, todos os dias. Já estou ouvindo Hilda gritar da sala, enquanto vai vendo e ouvindo as notícias no rádio e na televisão: "me tragam meu pinico de estanho que eu vou vomitar"; e depois: "agora é tarde, negão, já vomitei”.

É passar os olhos pelas crônicas de Hilda Hilst e conhecer, de um golpe, que o Brasil é um desastre persistente, fruto do que ela chamaria de pornocracia, ou reino da pornografia inata. A justa indignação, entretanto, nunca implicou a perda de humor; ao contrário, deu-lhe um mar de metáforas escabrosas. Talvez por isso, as 
crônicas ensaiem diversas possibilidades de criação no gênero que lhe é próprio, no âmbito do jornal.

Refiro algumas delas.

Em certas crônicas, Hilda justamente tematiza a expectativa usual de que o texto se efetue como comentário otimista das notícias recentes, com destaque para os casos que pudessem atrair "simpatia humana”. O roteiro lhe parece cínico e desonesto demais num tempo quase sem esperança à vista, além de ser patente sua falta de sintonia pessoal com o ar conformista dos anos 1990. Isso a obrigava a inventar saídas novas para a sua crônica, fora dos parâmetros de uma escrita "coerente e agradável".

Entre as saídas que ensaiou está a mistura de comentários de notícias recentes com poemas e textos de sua própria autoria, escritos e publicados em outros tempos, mas seguramente desconhecidos do leitor médio do jornal. Digamos que, nesses casos, ela usava as crônicas como divulgação de sua obra poética. Pessoalmente, não me parece que essa seja das soluções mais bem resolvidas. Os poemas, em geral, surgem descolados do restante da crônica, sobretudo por exigirem um tipo de concentração ou estratégia de leitura muito diversa daquela que orienta o início referencial da crônica.

Outra estratégia hilstiana para a crônica é a criação de fábulas com moralidade invertida, à maneira dos poemas hilariantes reunidos em Bufólicas, que misturavam a última lambança pública com historietas nonsense. Há textos, ainda, que simulam uma espécie de entrega ao fluxo de lembranças momentâneas e aos desvios mais inesperados do andamento argumentativo, o que produz uma impressão de imediatismo e improviso total, como uma conversa que irrompe, de repente, sem fim e sem começo, ali mesmo, no meio das páginas do jornal.

Enfim, diria que as estratégias inventadas por Hilda nas crônicas privilegiam um procedimento básico: colocam no centro da roda uma imagem caricata do leitor habitual do jornal, no extremo oposto do "leitor utópico" de que fala Boris Groys, o qual leria a obra exatamente como se gostaria que ela fosse lida. Hilda propõe como leitores de sua crônica velhos casais desanimados, satura- 
dos da própria companhia esvaziada; senhoras falsamente pudicas que simulam inocência escandalizada e a acusam de "nojenta" ao editor do jornal; representantes da "sociedade campineira" que, ao contrário do que supunham, não se distinguem em ignorância do "povão, caterva, populacho"; gente basicamente desesperada que, sem saber o que fazer do deserto da própria vida, aposta no alheamento de si como moralidade e no cultivo da boçalidade como trunfo da convivência.

Esse leitor evidentemente não compra livros, a não ser para fingir para o vizinho igualmente atoleimado uma inteligência que não tem. Essa caricatura de leitor avança e se amplifica até abarcar a humanidade inteira. E então, do seu leitor ela não pleiteia fraternidade ou sequer a amizade, mas, ao contrário, declara-lhe divórcio radical, cujo performativo é dado pela fórmula: "sou gente não". Esta é sua variante do I would prefer not to, frase com que Bartleby, a célebre personagem de Melville, faz recuar o seu ofício mecânico e contingente de escriba a um estado de negatividade primordial.

De modo geral, entretanto, as crônicas significam a abertura para uma grandeza artística que não se efetua nelas. São geralmente resumos, sínteses cômicas, desfechos caricaturais de algo que já se passou mais completamente em outro lugar. São um modo despachado de dizer de novo o que já disse, mais e melhor, na prosa ou na poesia, mas que ali, no campo do jornal, gera a alegria perversa de maltratar quem não a leu. 


\section{A EMINÊNCIA DA MORTE NA DRAMATURGIA DE HILDA HILST: A possessa e $O$ Verdugo}

Éder Rodrigues

Sara Rojo

Os três últimos anos da década de 1960 (1967 a 1969) indicaram uma dedicação exclusiva do trabalho literário de Hilda Hilst à escrita dramática. Período em que a produção artística brasileira refletia, de forma direta ou indireta, o violento processo ditatorial. Nesse momento, o teatro e outras expressões artísticas sofriam com a censura e a repressão iniciada com o golpe militar de 1964. Na ratificação extrema do exercício opressivo com a proclamação do AI-5, a atividade teatral tornou-se um dos alvos de intervenção militar. A cena brasileira foi então tomada por grupos como o Teatro Opinião, o Teatro Oficina e o Teatro Arena, que exerciam sua práxis numa corrente de afronta, resistência e posicionamento diante do contexto. Nessa época se efetiva uma dramaturgia de impacto ante a situação vivida pelo país (Augusto Boal, Gianfrancesco Guarnieri, Oduvaldo Vianna Filho, Dias Gomes, Plínio Marcos, dentre outros). Segundo o estudo de Elza Cunha de Vincenzo na obra Um teatro da mulher (1992), também foi nesse período que surgiram os pilares do que se pode denominar como dramaturgia feminina nacional:

Nesse momento temos uma postura feminina bem modificada em relação à que a mulher costumava, em geral, manifestar em outras formas de expressão literária. Ela, agora, revela nitidamente uma 
consciência e uma sensibilidade atentas ao momento social, à deterioração das estruturas básicas da sociedade. (Vincenzo, 1992, p.14)

O teatro hilstiano está inserido nesta tomada de posição e remonta aos anos opressivos da ditadura no Brasil. Ele também está conectado com as atividades do teatro universitário da época e com o pensamento de cunho social como protagonista da cena, conforme a própria dramaturga afirma em entrevista concedida: "O meu teatro é como a CASA dentro de cada um de nós. CASA que não existe para morar, mas para ser pensada" (Viana, 1973).

Desse modo, a escrita dramatúrgica de Hilst tem como foco o poder subversivo que a palavra congratula em contato com o ato que a força cênica lhe agrega. É uma palavra de força política, com suspensão existencial diante das questões humanas e sociais que inquietam tanto o sentido individual quanto a coletividade. Porém, não se trata de um teatro facilmente determinado por correntes únicas de influências ou inserção. É um teatro que mistura os elementos, que equaciona, que esfacela a realidade e arquiteta outras esferas de tratamentos possíveis ao teatral. Hilst utiliza suas experiências como poeta e projeta novos formatos, outras maneiras de confabular códigos de comunicação, de desconstruir signos e estruturas. Nas palavras da própria autora, em entrevista concedida ao Diário de São Paulo de 29 de abril de 1973:

As gentes, as pessoas em geral têm medo da ideia, da extensão metafísica de um texto, mas tanto minha prosa como a minha dramaturgia existem somente porque acredito que o próximo século será metafísico. Não me interesso pelas pequenas odisseias domésticas, interesso-me pela situação limite do homem. Não me peçam para pôr os pés na terra se o que pretendo é o fogo do espírito. O espírito é voraz e sofre tensão dolorosa e contínua. Eu sofro de intensidade e de paixão. E gostaria de ter as plantas dos pés sobre a esplêndida superfície da cabeça. (Viana, 1973)

Não é de se espantar que o teatro hilstiano tenha chamado atenção de estudiosos no exterior, diante do fato de não ter encontra- 
do ressonâncias, reconhecimento e abrangências dentro do Brasil. O primeiro estudo completo configurado em um livro solo sobre todas as peças da autora não foi realizado no Brasil. Alva Martínez Teixeiro publica em 2009 pelas Publicacións da Biblioteca-Arquivo Teatral Francisco Pillado Mayor, da Universidade da Corunha, na Espanha, a obra O herói incómodo - Utopia e pessimismo no teatro de Hilda Hilst. Trata-se do primeiro livro crítico que se debruça sobre a dramaturgia hilstiana e que analisa inúmeras questões e complexidades sobressalentes nas peças, sublinhando, sobretudo, as correlações entre os prospectos utópicos e a linhagem pessimista das obras. Anteriormente, os textos que referenciaram o teatro de Hilst foram o de Anatol Rosenfeld, em 1969, o estudo mais abrangente de Elza Cunha de Vincenzo (no capítulo do livro Um teatro da mulher, de 1992) e o de Renata Pallottini, no capítulo sobre o teatro que integra a edição dos Cadernos de Literatura no volume dedicado à autora, em 1999. O teatro de Hilda Hilst só é publicado de forma completa em 2008, pela editora Globo, mais de 40 anos depois de escrita a primeira peça.

Nessa publicação, Alcir Pécora faz colocações pontuando o tom de embates e debates que a edição completa da dramaturgia hilstiana provoca. Com relação às obras, o crítico questiona: "Relidas como texto somente, funcionaria como teatro, hoje?” (Pécora, 2008, p.19). Esta pergunta inquieta os autores do presente texto, pois percebemos que a resposta, sendo afirmativa, remete a questões do texto dramático, principalmente no fato de que a potência dramatúrgica não está apenas no que é dito (que no caso das obras de Hilst continua sendo pertinente), mas também na forma como o texto dramático amplia sua projeção espetacular, além da maneira lacunar com que se opera a instância política e a elevação da morte como um recurso trágico de transcendência do pensamento articulado em cena.

\section{Uma nova América em A Empresa (A possessa)}

Este texto inaugura em 1967 a escrita teatral de Hilda Hilst. Em Belo Horizonte, no ano de 2003, houve uma montagem de A 
empresa (A possessa) sob direção de Juarez Dias, também produtor e organizador do Círculo de Atividades Integradas Hilda Hilst que, em 2002, promoveu eventos sobre a obra da autora na capital mineira. O subtítulo da peça "estória de austeridade e exceção" já indica os caminhos que a obra percorre. A exceção à qual se dirige tem amplos reflexos na personagem protagonista - América -, duramente atacada por ter ideias próprias e, consequentemente, por colocar em risco as estruturas vigentes representadas no internato onde está inserida.

A peça, escrita para funcionar como um "teorema”, espécie de "redefinição" dos sujeitos ou, inclusive, como peça didática, nunca realista, apresenta-se como uma crítica que se pluraliza diante das instituições de controle, reprodutoras e moderadoras do pensamento e das ideias. Esse embate é a força propulsora que move o texto em suas ressonâncias a partir da esfera cênica que Hilst encarcera em um espaço físico fechado.

O texto recorre a perguntas, indagações e prerrogativas que ameaçam desestruturar a ordem. América se constrói como personagem nessa esfera de exceção, até porque em tal espaço ela é a única que cultiva um ideário não catequizado, conservando-se jovialmente livre do que lhe é imposto pensar.

América: Eu digo as coisas que penso. Só isso. Se elas são más não sei. Muitas vezes eu nem sei quem sou. Mas penso que não há mal nenhum em perguntar o que não se entende. [...] Assim é que começam as coisas. Com as perguntas. (Hilst, 2008, p.40)

O plano interrogativo que América constrói no decorrer das cenas é sedutor para as "postulantes" - as pessoas que estão no escalão mais baixo do internato -, inclusive por demonstrar aptidão para duvidar de tudo que já está institucionalizado. A simplicidade de qualquer teor interrogativo que é inerente ao seu caráter ganha dimensões absurdas diante das figuras que a vigiam e que consideram perigoso o seu comportamento. $\mathrm{O}$ conflito inicial do texto, produzido por seu desejo de saber, faz efervescer a sinceridade da 
personagem, que desafia a camada blindada onde a instituição sustenta suas verdades imutáveis e inquebrantáveis:

América: Eu perguntei como é possível existir a frase "nossa senhora foi virgem antes do parto, no parto e depois do parto".

Monsenhor: Não nos cabe o julgamento dessas revelações. É preciso ter fé.

América: Mas eu penso.

Monsenhor: Mas a fé não pretende que você deixe de pensar. A fé não pretende que você abdique de sua inteligência.

América: Mas isso não é lógico. Como posso acreditar numa coisa que é absurda? Todo mundo sabe que é impossível ser virgem e dar a luz.

Monsenhor: Há verdades imutáveis. (Hilst, 2008, p.40-1)

As dúvidas se ampliam diante das múltiplas verdades que atingem o convívio no sistema fechado no qual ela se encontra e é isso o que preocupa o Monsenhor. Ele vê na atitude de América os alicerces abalados daquilo que ele representa e defende, ainda que a capacidade e a potencialidade de América exerçam uma atração, instigando-o a imaginar formas de cooptá-la.

As "verdades imutáveis" defendidas pelo Monsenhor trazem como resposta ressonâncias performáticas que ultrapassam o espaço de encenação, colocando em dúvida não só o que o prelado ressalta, mas também tudo o que América questiona - questionamentos que parecem imutáveis. A possessa imprime ao pretexto construído pela confabulação da cena aberturas múltiplas, interrogações e sondagens que não são permitidas ou "aconselháveis" dentro do sistema fechado do internato apresentado na peça. A extensão do recurso interrogativo da personagem central se alia à margem dos excluídos (talvez por isso a protagonista escolha reiteradamente "estar" junto das postulantes), o que também é uma maneira de fazer frente aos sistemas sociais arbitrários que se organizam sob a égide de uma verdade oficializada pelo poder e que exclui o diferente como não pertencente aos parâmetros do que essa sociedade de controle tem como aceitável. 
Os ecos da força do ideário da personagem na peça, mesmo que sejam letais, oferecem uma saída pelos deslocamentos que o interrogativo acarreta junto às fronteiras do pensar e do agir. A voz possessa, que não esconde mais seus ímpetos de grito e dúvida, arrisca-se contra a atmosfera que invisivelmente mantém as estruturas de poder, ordem e alienação. São discursos oriundos dos processos de silenciamento e que na obra funcionam como ratificadores dos desejos de transpor as verdades estabelecidas e resistir ao meio, ao grupo, à instituição e à sociedade. $\mathrm{O}$ discurso proposto por América questiona e propulsiona a ação ante a passividade e a inércia em que se encontram os meios. Esse discurso funciona como uma voz que articula e desestrutura o sistema imposto e as regras sociais devidamente seguidas à mercê de um silêncio quase interminável que rege o espaço no qual a personagem habita. As perguntas que emergem do texto agridem de forma direta o aspecto inquestionável da instituição religiosa, e, por amplitude, qualquer outro sustentáculo de poder e conformidade que se alicerça em verdades absolutas. O texto alerta sobre os sistemas castradores dos ímpetos de liberdade: "Será que uma ideia pode ser tanto como se fosse outro dentro da gente?” (Hilst, 2008, p.35).

América é interrogada pelo Monsenhor e, para se fazer entendível, relata a história de Eta e Dzeta. Como se fosse uma espécie de Sherazade, mas com apenas uma história, cria um suspense que envolve o prelado. Essa história será inserida performaticamente no contexto por América, que a transforma em plano de ação (mesmo que depois seja manipulada). Para destacar essa intervenção, recorremos à rubrica que a autora utilizou para sua inserção:

América, ainda com certa precaução, vai inventar uma estória porque sabe que a única maneira de dizer o que pensa é inventar uma estória nos moldes tradicionais, inventando pais mais ou menos normais e um irmão mais velho para que o Monsenhor dê maior importância ao relato. Eta e Dzeta são para América apenas símbolos de sua história, mas o Monsenhor vai encarar tais símbolos de maneira diversa, dando-lhes uma nova realidade, realidade essa insuspeitada para América. (Hilst, 2008, p.43) 
A história relatada é a de duas máquinas que se alimentam de luz e andam dentro de uma caixa de "matéria brilhante", percorrendo sempre o mesmo caminho ciclicamente, sem nunca desviar o percurso. Assim vivem e, desse modo, são observadas constantemente por um vigia. Nada modifica o comportamento dessas criaturas, que por seu modo de funcionamento metaforizam a forma esperada de reação da personagem, até o dia em que param o movimento perpétuo por seis segundos, assim como no desfecho parará América - só que para sempre. Num primeiro momento, essa história criada aponta para uma simbologia de transformar a ficção em realidade fazendo transitar vozes impedidas num plano "real" (o da cena) para explicitá-las no plano ficcional. Esse método de "dizer não dizendo" evidencia referências a essas duas criaturas no campo "científico", teatralizando o percurso contínuo ao qual a protagonista estava submetida e não poderia desobedecer. No entanto, logo veremos que a forma como os outros personagens absorvem e se apoderam dessa analogia acaba por desconstruir esse sentido sígnico, ampliando os indícios de funcionamento do domínio totalitário do poder. Tal situação nos faz pensar nas inúmeras vezes em que os jovens têm se revoltado ao longo da história e logo, também, têm sido utilizados para os fins conservadores de manutenção do sistema.

Essa história e suas implicações foram o recurso utilizado pela autora para interferir na ação dramática e aludir ao objetivo primordial, que era delegar ao texto consonâncias que remetessem aos teoremas. "O colégio é sugerido em linhas esquemáticas, geométricas, de que nasce um ambiente ascético, nu, como o mundo das ficções científicas" (Vincenzo, 1992, p.37). Essa intervenção, científico-ficcional, permite à autora dizer o que pensa diante do interrogatório. Aliás, não seria esse o mecanismo de deformar e contornar realidades, inventando outros planos situacionais que, no percurso escritural do teatro de Hilda Hilst, lhe possibilita dar vazão aos discursos e interrogações que inquietam o pensamento?

Após essa intervenção metanarrativa, os planos se movimentam e dão a impressão de estar suspensos, enquanto os personagens se 
transformam uns em outros de acordo com a circunstância que os envolve. As duas máquinas não são vistas pelo público porque estão dentro de uma caixa, mas percebem-se suas oscilações e ruídos (elementos sonoros do texto). Hilst espetaculariza a cena e, dessa maneira, acontece o jogo de realidades, no momento em que América interfere na história dessas figuras de porosa simbologia, ou seja, no plano e projeção de cena que a própria personagem inventou. No entanto, a história contatada passa a ser manipulada pelo Monsenhor e as Cooperadoras. Sobre essa inversão, Vincenzo sublinha:

É preciso, portanto, impedir que pense, castigá-la, ou, num lance político mais inteligente, integrá-la. Justamente por suas qualidades excepcionais, América pode ser de grande utilidade. Deve ser aproveitada. Como conseguir isto? É a própria América quem, sem o saber, lhes fornece ideias. (Vincenzo, 1992, p.38)

O plano de manipulação passa a protagonizar a história e todos os personagens começam a agir em função dele, manipulando o que América desvendou. O crítico Alcir Pécora, no prefácio do Teatro completo da autora, pontua:

A nota Hilstiana mais interessante não é, como se poderia esperar, a denúncia da repressão institucional sobre os jovens, mas sobretudo a atenção concentrada sobre a possibilidade terrível de que justamente os jovens mais criativos possam ser cooptados ou ter a sua imaginação posta a serviço de processo repressivo. Quando a personagem "América" inventa "Eta" e "Dzeta" supondo demonstrar sua imaginação, sua diferença em relação aos padrões anódinos da instituição, ela involuntariamente fornece as condições para uma repressão muito mais eficaz que a existente até então. (Pécora, 2008, p.10)

A estratégia lançada é a de, em vez de castigá-la, assimilar a inteligência de América a favor da instituição. À personagem é oferecido o cargo de vigilante da classe, visando a uma mudança às avessas, 
sem mexer nas aparências. A partir de então, há uma mudança brusca de comportamento na protagonista, inclusive quando esta é submetida a um julgamento pelo Inquisidor (que anteriormente era o Monsenhor). América passa a contradizer todo o seu ideário e a servir então de cobaia nesse laboratório instituído pelo poder, sendo investigada e obrigada a demonstrar abstrações por intermédio de equações que lembram as da pós-lógica.

Os delírios de América, misturados com as vozes da consciência, são repetidos e impelidos por uma imposição científica que toma conta da cena. América profere palavras sem nexo, mas fluidamente projetadas no imagético pensamento produzido em circunstâncias de repressão:

América (ainda falando consigo mesma, como se o Inquisidor não estivesse presente, comovida, sombria): Os olhos velhos e a vontade de amar sem saber como. Crescemos tanto as duas, tão inutilmente. Crescemos tanto que nem mais nos abraçávamos, nem sorríamos, como acontece àqueles que se amam. Eu dizia: Dá-me um pouco de ti, eu tenho sede. Tenho os olhos pisados de sonhar. (Hilst, 2008, p.95)

Nessas circunstâncias, a Superintendente e as cooperadoras resolvem eliminar metaforicamente América, cobrindo-a com um camisolão por onde a cabeça não passa: "E pode pensar à vontade agora... Mas naturalmente, sem a cabeça” (Hilst, 2008, p.68). Posteriormente, nos desmembramentos que a trajetória vai tomando, em momento de aparente cansaço, América transmuta-se na figura da própria autora, que verbaliza poemas próprios rejeitando o caminho de racionalismo operante imposto:

De luto esta manhã

Por vós, por vossos filhos

E não pelo meu canto nem por mim

Que apesar de vós ainda canto.

Terra, deito a minha boca sobre ti. 
Não tenho mais irmãos

A fúria do meu tempo separou-nos

E há entre nós uma extensão de pedra.

(Hilst, 2008, p.69)

Torna-se nítida a mistura dos gêneros literários e da fusão constante entre traços biográficos e instâncias do ficcional (os poemas de Hilst são inseridos como fala da personagem). Essa característica outorga à escrita da peça indícios de autoria de um autor-performer. Por outro lado, agrega-se a voz da América "personagem" à da América "continente", tantas vezes colocada à prova por sistemas de opressão e impedida de dar voz à liberdade, o que confere à peça um caráter de performance política.

No desfecho, América é levada a um interrogatório, onde a alertam para o fato de que Eta e Dzeta também registram nível de consciência, enquadrando condutas. No auge dos mecanismos opressivos, as cooperadoras não "atentam" para a morte de América. Das instâncias que a peça instaura e evoca, fica o caráter revolucionário da protagonista e os seis segundos em que as duas máquinas do plano fantasioso param, desobedecendo à ordem contínua imposta como inerente a seu funcionamento. Amplia-se com a morte da personagem a captura de outros desses seis segundos em que cessa a conformidade à qual somos impelidos na utopia de um novo caminho ou na construção de outra América.

\section{Manobras do invisível: $O$ verdugo}

A peça $O$ verdugo teve duas versões. A primeira, que remonta ao texto original, foi laureada em 1969 com o Prêmio Anchieta de Teatro, razão pela qual foi editada no ano subsequente. A outra versão é uma adaptação realizada com o diretor da montagem realizada em 1973, Rofran Fernandes, resultando da incorporação de novos elementos ao texto espetacular. Nessa peça, é vertida uma dinâmica de representação sobre determinadas problemáticas do contexto so- 
ciopolítico. A partir de fatos, conjunturas e metáforas situacionais, organiza-se um tratamento estético que procura ultrapassar sistemas autoritários por meio do conteúdo e da forma escolhida - os quais, nessa peça, sem dúvida são indissociáveis.

Nessa vertente de transposição, a peça assume uma demonstração direta do contexto a partir de uma estrutura dramatúrgica linear, enquanto, por outro lado, organiza características que rompem com o realismo, remanejando assuntos para espaços longínquos - no caso, um vilarejo que remete ao mesmo tempo a qualquer lugar e a lugar nenhum. A partir de um olhar distanciado daquilo que vemos, a peça apresenta uma imagem deslocada que se potencializa em sua aparente inatingibilidade. As duas formas (a história linear e a imagem deslocada) constroem uma estratégia textual.

De modo indireto observa-se o visível e o invisível das relações, os fatos alternados de uma conspiração e a hierarquia que suspende instituições à custa de uma massa subalterna. Nessas configurações, a cena se constitui de uma série de elementos que denunciam o modelo social autoritário "que decide a vida ou a morte dos seres humanos” (Agambem, 2010). No entanto, o material invisível permeia a formação dos poderes e da engrenagem que sustenta a ordem vigente. É a instância do invisível que abre perspectivas no desfecho, exatamente o contrário do que aconteceu em $A$ possessa, onde as forças advindas da história inventada se convertem em mantenedoras do sistema.

A espacialidade em $O$ verdugo parece se distanciar para então aproximar todo e qualquer resquício. "Em algum lugar triste do mundo” (Hilst, 2008, p.367) se dá o impasse de uma profissão não muito comum: um verdugo, cujo ofício é liquidar condenados pela justiça oficial dos homens. Na peça, o verdugo se nega a desempenhar sua função porque o acusado mexeu com seu pensamento numa dimensão que lhe escapa dos princípios. Sente que o condenado é diferente dos outros: "O homem tem um olhar... um olhar... honesto. [...] Limpo, limpo por dentro” (Hilst, 2008, p.370).

Nessa peça, Hilst propõe sentidos que ultrapassam o acompanhamento da história. O que de fato fez este homem, ao qual se 
condena, ou que crime cometeu? É o deslocamento estrutural que a autora maneja para que adentremos no situacional invisível da peça que coage o enredo. Na conversa familiar inicial, onde os fatos são servidos na mesa como prato principal a ser devorados por alguns (e para o amargo jejum de outros), as táticas do invisível são alçadas como uma torrente de interrogações que permeiam a peça toda. Ninguém sabe direito qual foi a falta grave impelida pelo tal homem e que o levou à condenação. Esse traço performático não só leva o leitor/espectador a especular sobre os atos do personagem como também reconstrói o percurso óbvio de colocar em pauta os mecanismos de formulação, determinação e execução das leis. O homem está na mesma condição do personagem de Diante da lei (1916), de Kafka.

Sobre o que o homem cometeu, a autora deixa faiscar ainda no início da peça: "Ele pôs fogo em todo mundo. Fogo, só isso" (Hilst, 2008, p.368). Evidentemente, a palavra fogo incendeia muito mais que as chamas poderiam fazer. Principalmente por seus ímpetos de atiçar ideários presentes em nosso imaginário massacrado por guerras e autoritarismos. O que o homem fez foi falar, só falar. A performance do texto recobra aqui seu teor mais acentuado por meio do poder da palavra. Como protagonistas do plano, aparecem o funcionário que se nega à função de matar e seu filho, que o apoia em sua decisão, além do acusado que, performaticamente, recobra visibilidade pela palavra que proferiu.

No contexto da peça, a simbologia do poder é imposta como ação a ser cumprida, sem extensão aos porquês de suas demandas e sem limites para fazer que ela se cumpra segundo o desejo de autoridades superiores e que nunca se mostram. Diante do conflito imposto pela negação do verdugo, os juízes não ensaiam muito e logo propõem o suborno:

Juiz velho: Procure entender... escute. O senhor terá regalias.

Verdugo: Mas nunca foi preciso qualquer coisa além daquilo que eu ganho para fazer o meu serviço.

Juiz jovem: Mas... como é um caso difícil, nós entendemos que será justo ajudar o senhor. (Hilst, 2008, p.368) 
A tentativa de suborno desmascara não só um sistema, mas todo o histórico de uma sociedade que se ergue à custa deste tipo de prática. O suborno não é oferecido só à família e ao povo da Vila, mas também, num desdobramento performático, é estendido até nós. Estamos todos diante de tantos "acordos invisíveis" que sabemos dessa natureza. Na peça, a personagem da Mulher (submissa e subalterna à própria condição) é a primeira que se vende:

Mulher: Quanto é o auxílio, Excelências?

Juiz jovem: É... de alguns milhões.

Mulher: Alguns milhões?

Juiz velho: Doze... treze.

Filha: Meu Deus! Meu Deus! (Hilst, 2008, p.384)

A Mulher, diante do valor que permitiria seus sonhos de consumo, apresenta-se então para substituir o marido e, segundo ela própria, para "cumprir a lei”. Julga-se apta por ter a mesma estatura do marido e assinala que não terá problemas porque no cerimonial de execução o verdugo sempre usa um capuz. A família subornada resplandece ante a "grande luz" dos que têm mais sobre a miserabilidade de quem só é esvaziado pela fome. Não é um retrato de nossa miséria, mas um plano fílmico, vivo e contínuo de uma América Latina constantemente subornada. Mas a questão é que o preço da dignidade é muito mais complexo do que simplesmente classificar vendidos e não vendidos. A história é muito mais abissal e é por essas funduras que o verdugo se expõe e, inclusive, se oferece para ser a vítima no lugar do homem. A iminência da morte é a única que parece capaz de garantir a liberdade do outro. Diante da proposta financeira, além da Mulher, a Filha e o Noivo também se mostram remoídos pela expectativa de melhora nas condições em que vivem, surgindo assim inúmeras justificativas para o aceite do dinheiro ilícito:

Filha: Pai, o homem já morreu. Não somos nós que vamos matá-lo. Ele já está morto. Só falta a terra cair em cima do cara. 
Verdugo: Está vivo. Igual a mim.

Filha: [...] O senhor é... bom demais... e os outros pisam em nós quando não se tem dinheiro. (Hilst, 2008, p.397-8)

A fala da personagem remete a um estudo da situação das personagens estruturantes do plano geral da arquitetura textual. As personagens não são nomeadas, mas postuladas segundo a função que exercem ou a categoria a que pertencem no interior do sistema familiar/social e, principalmente, numa esfera de poder sócio/capital. Assim, de um lado temos os que compõem a família do verdugo: o filho, a filha, a mulher e o futuro genro. Do outro, a representação clássica do poder: os dois juízes, o velho e o mais jovem. Papéis definidos que, antes de articular quaisquer possibilidades de nomes, determinam os níveis de superioridade e subalternidade: "Verdugo: Eu acho que o homem não merece, os senhores entendem? [...] Juiz jovem: Mas não é a vila que julga o homem. Pra isso nós existimos. Já dissemos, foi tudo dentro da lei” (Hilst, 2008, p.383).

O imagético da constituição do que seria a figuração dos coiotes aparece gradativamente, fortalecendo o aspecto performático do texto que integra o lado instintivo do animal, a força e a garra resistentes às imposições e ortodoxias. $\mathrm{O}$ coiote, que também ganha recorrência digna de um personagem ou figuração dentro da peça, suscita a força corregedora de atos em uma estrutura que traz estranhamentos à trama, criando outra espetacularidade para justamente agir num terreno de pouco conforto. Essa gradação vai desde a denominação de "coiotes" até a explicação do filho sobre a razão de tal denominação:

Filha: Pois eu não entendia o que ele falava.

Filho: Não mente. Você sabe muito bem o que ele falava.

Juiz Velho: Ele não respeitou vocês. Ele insultava vocês.

Verdugo: Insultava? Não sei disso.

Juiz jovem: Ele chamava vocês de coiotes. (Hilst, 2008, p.394)

$[\ldots]$ 
Filho: Ele dizia que os coiotes não costumam viver eternamente amoitados. Que é preciso sair da moita. [...] Para que vejam as nossas caras de coiotes e respeitem a gente. E se nos respeitarem, nós poderemos um dia... achar o nosso corpo de pássaro e levantar voo. (Hilst, 2008, p.394-5)

Nada fica claramente exposto, mas tudo é notório. Esse é o triunfo performático no qual se insere o texto $O$ verdugo. As figuras da representação ficam abaladas, enquanto cresce uma força diante do invisível, que por sua vez se circunscreve no plano do não tratado, da evocação de forças de aliança e cisão. A prioridade das manobras que Hilst executa na invisível presença do homem condenado, na sua também inaudível fala e na movediça força impelida sobre as garras do coiote faz surgir uma força subjacente que vive sob o conflito representacional. Performam-se as incertezas da história e as novas ideias que oferecem paradigmas propulsores de ideologias de resistência.

O primeiro ato se encerra com a mulher aparecendo já vestida de verdugo, contrapondo qualquer julgamento superficial ao duelar com os subtextos de pessoas, famílias e estados que se vendem pelo sonho da "dignidade" contornada pela estrutura selvagem que rege o sistema capitalista. Hilda Hilst também utiliza sua força poética na construção da personagem do verdugo, recheando-o de investidas que vão da sua inserção social enquanto ser político ao lírico de suas impressões, sentimentos e utopias.

$\mathrm{O}$ verdugo se sensibiliza com tudo o que está vivo. A subversão poética a partir da condição constituinte do ofício do personagem e a predileção pelos ideais libertários ameaçados são colocadas pela autora como geradores do conflito. O verdugo se desnuda na condição de ser comovido. Assim, o potencial de sensibilidade que a obra confere ao personagem é o que Hilst procura produzir como indício de uma vida mais humana e menos taxativa:

Verdugo: O homem está vivo. Essa lei dos homens não conta.

Filho: Essa é a única lei que conta. O senhor não viu? 
Verdugo: Ele apertou a minha mão. Ele apertou a minha mão de um jeito.

$[\ldots]$

Filho: Falou?

Verdugo: Sim.

Filho: O quê, pai?

Verdugo: Nós somos um só. Eu e você somos um só. (Hilst, 2008, p.400-1)

No segundo ato, as estruturas que movem a peça são amplamente abaladas, seja pela descoberta do suborno, pelo desmascaramento da mulher ou pela substituição do condenado pelo próprio verdugo. É também no segundo ato que o suborno se estende, quando então o povo é comprado, aprovando a execução.

Nessas revelações em praça pública, Hilst vale-se de uma sobreposição que circunda valores de ética e moral, vida e morte, resistência e calúnia. O discurso libertário em performance fica nas confusas garras capazes de subverter o subalterno. Os ideários proféticos do homem que se antecipa em nome de uma ideia parece ser o pilar que conspira para uma revolução das estruturas e confronta dois mundos: o dos coiotes, aliado às ideias libertárias, versus o mundo do vilarejo, exposto numa microrrepresentação do espaço macro do autoritarismo e da supremacia do poder de consumo que tudo compra.

O mundo dos coiotes é o natural, capaz de desestruturar o pensamento e os moldes do que se tem como imutável. Por isso, qualquer plano que o fomente pode parecer tragicamente perigoso. Esse mundo não é só uma metáfora textualmente explorada pela autora, mas uma força que existe no interior de quem resiste. Pouco se sabe desse universo e talvez seja por isso que o texto se torne difícil de ser montado. Não é tarefa fácil evidenciar essas manobras do invisível no palco, localizadas em outro lugar que o sujeito não costuma ver nas formas teatrais conhecidas. Por isso, as críticas que Hilst recebeu em virtude da montagem de 1973 são questionáveis: 
Com um drama tão pouco convincente e quase sem pés na terra, o espetáculo procura sobreviver pela valorização dos interlúdios poéticos. [...] Uma peça escrita aparentemente sem compromisso com nenhuma tendência teatral, mas também absolutamente sem compromisso com as experiências do dia a dia. (Lima, 1973)

A crítica de Mariângela Alves Lima parece incoerente quando são consideradas as inúmeras problemáticas que a peça desenvolve e, principalmente, quando escutamos as palavras de Didi-Huberman: "devemos fechar os olhos para ver quando o ato de ver nos remete, nos abre a um vazio que nos olha, nos concerne, e em certo sentido, nos constitui" (Didi-Huberman, 1998, p.31). Entendemos que as correspondências que a resenha crítica observa como contrárias a um pleno entendimento são, na verdade, o triunfo maior da peça. Nessa obra, a contextualização acontece por outros intermédios que não a correlação. Por isso, talvez a opção da autora por colocar, na palavra do condenado, frases confusas de desfecho: "Homem: Eu não soube dizer. Eu não soube dizer como devia. Eu não me fiz entender. [para o verdugo]. Faz o teu serviço” (Hilst, 2008, p.424).

As duas mortes que ocorrem em $O$ verdugo, a do executor e a do executado, são produto das barbáries que a violência proclama diante de sistemas autoritários que atuam longe dos interesses das comunidades sociais, onde tudo aquilo que se mostra exceção e contrário ao que já está sofre as penalizações que a vigência decreta. Mas não é na figura violenta das mortes que Hilst apoia o efeito performático da peça, mas na presença do que provoca o ato de violência:

Nesse instante entram na praça os dois homens-coiotes. [...] Ficam de frente para o público, examinam o público fixamente e depois voltam as cabeças em direção ao patíbulo. Tem-se a impressão de que não foram vistos por nenhum dos cidadãos, nem pelos juízes etc. Apenas o filho do verdugo dá a impressão não só de que os conhece, mas de que os esperava. (Hilst, 2008, p.427) 
É nesse referencial que se circunscreve o desfecho suspenso da peça. O filho do verdugo olha para os homens-coiotes. Em seguida, olha pela última vez o corpo do pai e anda em direção aos homens. Esse ato é a negação daquele mundo determinado por uma hierarquia que estabelece o controle por meio do suborno, onde a ideia é esmagada pelo autoritarismo, ainda que isso implique a morte de outros. O caminho que o filho percorre junto aos homens-coiotes é uma estrada performática de desvio e resistência. Essa estrada confere à obra conotações abertas de interpretação, completude e coletivização de forças para as interpretações possíveis do leitor/espectador.

Partindo das contribuições de Derrida na obra A escritura e a diferença (1971) e das teorizações que apontam para a retomada do signo não como uma estrutura fixa incorporada a um sistema estável, mas acrescido a contextos anteriores (passados) e posteriores (futuros) que operam em uma desintegração de sua própria unidade, permanência e estabilidade para falar de outra coisa, é que pensamos que $O$ verdugo permite um diálogo com o conceito de obra aberta de Umberto Eco (1991). Os textos sistematicamente escritos sob essa égide continuam sendo reinventados pelas múltiplas interpretações que deles são feitas. Tais interpretações são possíveis no terreno ambíguo da pluralidade de significados que convivem num só significante, mas estão de maneira lacunar sugeridas no texto pela autora, possibilitando uma gama de completude por parte do leitor/espectador.

O texto está, pois, entremeado de espaços brancos, de interstícios a serem preenchidos, e quem o emitiu previa que esses espaços e interstícios seriam preenchidos e os deixou brancos por duas razões. Antes de tudo, porque um texto é um mecanismo preguiçoso (ou econômico) que vive da valorização de sentido que o destinatário ali introduziu. (...) Em segundo lugar, porque à medida que passa da função didática para a estética, o texto quer deixar ao leitor a iniciativa interpretativa, embora costume ser interpretado com uma margem de univocidade. Todo texto quer que alguém o ajude a funcionar. (Eco, 1991, p.37) 
A figura do coiote é um dos indícios performáticos mais recorrentes do segundo ato e que vem a deixar em lacunas toda a suposição de condenação e de desfecho pessimista que emergiu no contexto anterior da trama. Fica nítido que o homem condenado era uma figura de resistência que procurava alertar os outros sobre sistemas e opressões. A matéria invisível que a autora faz surgir como maneira de refletir sobre o que já está é o que sustenta a peça. O elemento performático do texto reincide sobre as significâncias do revelar em risco, do abrir interpretações e lançar ultimatos de ruptura, contrapor. O filho segue os homens-coiotes numa projeção de outra expectativa de pensamento, onde a reflexão e o resistir apresentam suas garras. No contexto, amplia-se o convite até nós num novo giro performático.

\section{Tecendo algumas palavras finais}

Nas duas peças, o letal possui um papel fundamental por marcar o limite da existência, remetendo a um estado de controle que viola essa fronteira intransponível. Em A possessa, a personagem, que abria as comportas da revolta, morre interrogada, vigiada. América não deixa nenhuma pessoa que a substitua, só fica a lembrança da força derrotada e o alerta às manipulações que o poder pode exercer sobre nós. Em $O$ verdugo, o pai e o homem morrem sob a custódia do povo manipulado pelos representantes de um poder que é presentemesmo sem o estar. Mas fica o filho, que continuará a construção de uma maneira de viver sugerida pelos dois executados. Isso permite visualizar a possibilidade de outro mundo, negada em $A$ possessa.

A morte se eleva como um pretexto abissal para ser retomada no palco, abrindo assim significações para os riscos que a perda da liberdade implica. Nas duas peças, o caminho trágico previamente montado nos permite lê-las como alternativa aos arbítrios do pensamento. Tanto em $O$ verdugo quanto em $A$ possessa a morte faz o trajeto do eu ao outro, do particular ao coletivo, gerando alternativas de reconstrução dos modelos impostos. 


\section{Referências bibliográficas}

AGAMBEN, G. Homo sacer. O poder soberano e a vida nua. Trad. Henrique Burigo. 2.ed. Belo Horizonte: Ed. UFMG, 2010.

DERRIDA, J. A escritura e a diferença. São Paulo: Editora Perspectiva, 1971.

DIDI HUBERMAN, G. O que vemos, o que nos olha. Trad. Paulo Neves. São Paulo: Editora 34, 1998.

ECO, U. Obra aberta. Forma e indeterminação nas poéticas contemporâneas. Trad. Giovanni Cutolo. São Paulo: Perspectiva, 1988.

HILST, H. Teatro completo. São Paulo: Globo, 2008. Teatro reunido. São Paulo: Nankin Editorial, 2000.

LIMA, M. A. de. Sem pés na terra. Revista Veja, São Paulo, 25 abr. 1973. PÉCORA, A. Nota do organizador. In: HILST, H. Teatro completo. São Paulo: Globo, 2008, p.7-19.

TEXEIRO, A. M. O herói incómodo: utopia e pessimismo no teatro de Hilda Hilst. Corunha: Publicacións da Biblioteca-Arquivo Teatral Francisco Pillado Mayor/Universidade da Corunha, 2009.

VIANA, H. Hilda Hilst, um poema no teatro. Diário de São Paulo, São Paulo, 29 abr. 1973. Jornal de Domingo.

VINCENZO, E. C. de. Um teatro da mulher: dramaturgia feminina no palco brasileiro contemporâneo. São Paulo: Edusp, 1992. 


\section{De Oswald de Andrade a Hilda HILST: O LÚDICO NA LITERATURA BRASILEIRA DO ÚLTIMO SÉCULO ${ }^{1}$}

Nilze Maria de Azeredo Reguera

Ao direcionarmos um olhar crítico em relação à modernidade, ao seu projeto e às suas utopias, sobretudo tal como foram delineados desde o século XIX e, em especial, pelas vanguardas no início do último século, é notável a relação do sujeito com a temporalidade e com a materialidade, seja esta a da própria linguagem ou a do suporte, como a tela ou a folha em branco. No caso desta, poderíamos indagar em que medida já seriam "clássicos" o lúdico articulado no/pelo lance poético de S. Mallarmé, o percurso do flâneur em C. Baudelaire, a problematização daquele que não se enquadra à estrutura de dominação em F. Kafka, exemplificada principalmente pela maquinaria e pelo progresso, o fluxo de consciência e as suas dinamizações em J. Joyce, T. Mann ou S. Beckett. Da mesma maneira, no contexto da literatura brasileira, uma visão acerca da "identidade" ou do sujeito em Mário de Andrade, e o singular "ato digestório" ou as experimentações com a linguagem e com a formatação dos gêneros e os registros em Oswald de Andrade.

Nesse período, o contato com a materialidade foi fomentado por estratégias como a autorreferencialidade e a autocrítica, que

1 Parte deste texto foi pulicada como "Oswald de Andrade e o legado lúdico". In: Fronteiraz, v.12, p.75-88, 2014. 
promoveram a interação entre artista, texto, contexto e recepção. Presente em diferentes ênfases nas obras de autores modernos, esse trato do sujeito com a matéria verbal foi ganhando significativo destaque na literatura brasileira ao longo do último século. Oswald de Andrade parece ser, desse prisma, um dos autores que inicialmente e com maior amplitude se valeu dessas estratégias: Memórias sentimentais de João Miramar, de 1924, Pau-Brasil, de 1925, e, principalmente, Serafim Ponte Grande, escrito na década anterior e lançado em 1933, apresentaram "um vasto potencial de usos da língua, em diferentes níveis e registros" (Fonseca, 2008, p.106), que em muito contribuíram para um processo de reversão, "subverte[ndo] a ordem e provoca[ndo] uma situação de rebaixamento, desqualificando hierarquias" (Fonseca, 2008, p.109). ${ }^{2}$ Note-se, por exemplo, Serafim Ponte Grande: se não bastassem referências à vida e à obra, trazendo à tona um sujeito (textual) que delineará ao leitor certos fatos por ele "transpost[os]" (Andrade,

2 A fortuna crítica e o próprio escritor modernista salientaram a influência de Gregório de Matos, como exemplificada no poema "Relicário", de Pau-Brasil. Em certo sentido, a noção de "jogo” e o trato lúdico com a linguagem/ arte fariam do poeta seiscentista uma espécie de precursor, instituindo certos procedimentos que a modernidade intensificaria e/ou redimensionaria. É desse viés que: "Ludicidade e jogralidade representariam, portanto, elementos fundamentais e inseparáveis na estrutura do verso de Gregório, em cuja tessitura localizamos não só os expedientes comuns a toda a técnica da poesia barroquista - as paranomásias, as aliterações, as assonâncias, os quiasmas, as elipses etc. -, porém uma vontade maior de jogo, diríamos até um indomável ímpeto jogralesco, traduzido na vivacidade rítmica da frase, na exploração dos contrastes e dos efeitos de dissonância e correspondência sonora as palavras" (Ávila, 1971, p.96). Assim, "para uma época que sanciona como elementos da estrutura da obra de arte [...] o insólito, o aleatório, o informal, o lúdico, é certo que paradigmas a recolher-se do passado criativo do homem já não poderiam ser senão aqueles mais consentâneos com [...] o modo de ver, o modo de expressar de nosso tempo. Daí o significado que, sob tal aspecto, assume o barroco, arte que antecipou [...] muito da formatividade da arte moderna, ao introduzir na criação plástica a perspectiva em diagonal e a ilusão do movimento, estendendo à criação literária [...] uma idêntica diagonalidade de linguagem e uma equivalente sugestão cinética no dinamismo das imagens” (Ávila, 1971, p.99). 
2007, p.48), bem como a ambivalência do prefácio, dada por um viés irônico em relação à recepção, o qual ao longo da obra vai rompendo com qualquer "seriedade" ou "aconselhamento" ainda pressupostos, o trato lúdico, autorreferencial, mostra-se um dos veios pelos quais se dá o processo de reversão andradiano, visto desde a abertura do livro: ${ }^{3}$

\section{OBJETO E FIM DA PRESENTE OBRA (SERAFIM PONTE GRANDE)}

Quem conta com a posteridade é como quem conta com a polícia.

Aliás, minha finalidade é crítica. A obra de ficção em minha vida corresponde a horas livres, em que estabelecido o caos criador, minhas teorias se exercitam com pleno controle.

O que é a obra de arte? Fenômeno social ou antissocial. Ciclos. Caráter coletivista, caráter individualista. Classicismo e pesquisa. Romantismo e decadência.

[...] O novo mundo produziu o homem serafiano cuja riqueza é mal adquirida.

[...] No mundo atual, Serafim traz duas razões: o bom câmbio e a ignorância audaz. Bisneto de conquistador, avesso do bandeirante, é filho pródigo que intervém na casa paterna porque viu mundo, travou más relações e sabe coisas esquisitas. Choque. Confusão. Regresso inadatável.

O que faz a obra de arte diferente de uma ópera de Carlos Gomes? Não há regras. É sempre diferente.

Os retardatários - você com certeza, leitor - pensam que têm gosto porque aprenderam umas coisinhas. São mantenedores do

3 Se Gregório de Matos poderia ser considerado um precursor do trato lúdico, Machado de Assis e Manuel Antônio de Almeida também o seriam na medida em que o uso do prefácio e um diálogo supostamente "avisador" no primeiro, e a aparente e recorrente inadequação de um herói às avessas, malandro e sedutor, no segundo, tornar-se-iam matéria a ser explorada e redinamizada em Oswald de Andrade. 
gosto. O que sai das coisinhas é de mau gosto. Mas nós endossamos o mau gosto e recuperamos para a época o que os retardatários não tinham compreendido e difamavam.

Transponho a vida. Não copio igualzinho. Nisso residiu o meu equívoco naturalista. A verdade de uma casa transposta na tela é outra que a verdade da natureza. Pode ser até oposta. Tudo em arte é descoberta e transposição.

O material da literatura é a língua. A afasia da escrita atual não é perturbação nenhuma. É fonografia. Já se disse tanto. A gente escreve o que ouve-e nunca o que houve. (Andrade, 2007, p.47-8)

Se há uma advertência ou um ordenamento em relação ao que será apresentado por parte desse emissor, há, ainda, um olhar que coloca em foco a própria matéria verbal (linguagem e tema), e não somente a sua moldura ou o seu suporte, caracterizando um ludismo, ou seja, um jogo entre o cômico e a seriedade, o "bom" e o "mau" gosto, a tradição ou a retardação e a inovação, que não deixaria de lançar um olhar em face daquela contemporaneidade. Eis, então, a "transposição" oswaldiana: um jogo autocrítico e autorreferencial que se vale de rupturas e de quebras de expectativas, empreendido desde os momentos iniciais da (sua) obra. É, pois, por meio desse processo que o percurso do protagonista Serafim ganha corpo - na sua infância e mocidade, no seu casamento e nas suas aventuras, até o seu singular fim:

\section{PRIMEIRO CONTATO DE SERAFIM E A MALÍCIA}

$$
\begin{aligned}
& \mathrm{A}-\mathrm{e}-\mathrm{i}-\mathrm{o}-\mathrm{u} \\
& \mathrm{Ba}-\mathrm{Be}-\mathrm{Bi}-\mathrm{Bo}-\mathrm{Bu} \\
& \mathrm{Ca}-\mathrm{Ce}-\mathrm{Ci}-\mathrm{Co}-\mathrm{Cu} \text { (Andrade, 2007, p.63) }
\end{aligned}
$$

O "primeiro contato", que em muito se aproxima de outras produções oswaldianas, como Pau-Brasil e Primeiro caderno do 
aluno de poesia Oswald de Andrade, de 1927, claramente se baseia no jogo com a língua e suas potencialidades. Ao inserir por meio da inversão o jocoso ou o obsceno em seus textos, Oswald opera com o trânsito de estilos, registros, gêneros, indo do esperado ao inesperado, do sério ou do trágico ao cômico ou ao risível, da tradição à sua reinvenção. É nesse sentido que:

O filão da comicidade passa pelo procedimento artístico, pelas ações das personagens, pela crítica aos falsos padrões sociais. O discurso sério-cômico em Serafim em muitos aspectos está permeado pela deformação e pela bufonaria circense. $O$ exagero verbal e a desmedida comicidade gestual contribuem para essa subversão do mundo da personagem. (Fonseca, 2008, p.130, grifo nosso)

Não são somente o autor Oswald, sua reverberação num eu textual ou a personagem Serafim que se colocam em cena; é própria linguagem, que é evidenciada em sua corporeidade, nos usos que dela são feitos. Exemplar disso é "Folhinha conjugal, ou seja, Serafim no front”, um singular diário em que o protagonista, tentando ascender socialmente, registra suas relações com a esposa Lalá, os amigos e as amantes, como também suas indagações, sua visão de escritor e suas predileções ou prováveis influências no meio literário:

\section{Quinta-feira}

Partida de bilhar com o Manso da Repartição. Joguei mal. Pequena emoção guerreira.

Lalá quer passar o inverno em Santos. Já fiz os cálculos e vi que o ordenado não dá, mesmo com os biscates.

No entanto, deve ser muito bom mudar de casa e de ares, de objetos de uso familiar e de paisagem quotidiana. Seria excelente para mim, homem de sensibilidade que sou. E quem sabe se tam- 
bém mudar de paisagem matrimonial. Sed non pos-su-mus! como se canta no introito da missa.

\section{Terça-feira}

Ando com vontade de escrever um romance naturalista que está muito em moda. Começaria assim: "Por todo o largo meio disco da praia de Jurujuba, havia uma vida sensual com ares gregos e pagãos. O mar parecia um sátiro contente após o coito."

Nota: Não sei se escreverei a palavra "coito" com todas as letras. O arcebispo e as famílias podem ficar revoltados. Talvez ponha só a sílaba "coi" seguida de três pontinhos discretos. Como Camões fazia com "bunda".

(Andrade, 2007, p.71)

\section{[...] Terça-feira}

Vou tomar chá, hoje, às oito horas, em casa do Comendador Sales. É o Manso quem me reboca. Um dia, hei de comprar um Ford a prestações.

\section{Domingo}

Miserável despertar de sensualismo. Releio as apimentadas memórias de Jacques Casanova (Andrade, 2007, p.74-5)

\section{[...] Segunda-feira}

Afinal a criada foi uma desilusão. Compursquei o meu próprio leito conjugal, aproveitando a ausência de Lalá e das crias. No fim, ela gritou!

- Fiz um peido!

Travessuras de Cu... pido! (Andrade, 2007, p.77)

Serafim Ponte Grande, ao explicitar com veemência procedimentos que "desarticula[m] [tanto] a forma romanesca tradicional" (Campos, 2007, p.14) quanto a temática referente à burguesia paulistana, a um almejado comportamento ou à moralidade, o contraste entre o velho e o novo, e o por vezes aclamado progresso, contribuiu 
para instituir na literatura brasileira o espaço e a tradição do lúdico, isto é, de um jogo com a materialidade e os vários níveis de sentidos - o das palavras, o dos gêneros literários, o do livro-objeto artístico e o do livro-suporte. Apesar de essa experimentação do e com o lúdico mormente enfatizar aspectos verbais ou metalinguísticos, ela não deixa de explicitar a experimentação de Serafim em sua identidade, em suas relações sociais, em seu cotidiano, enquanto "filho pródigo" (Andrade, 2007, p.48), herói às avessas, personagem e cidadão:

As onze badaladas da torre de São Bento furam a cinza assombrada do dia, onde as chaminés entortadas pelo bombardeio não apitam.

É a hora em que eu, Serafim Ponte Grande, empregado de uma repartição federal saqueada e pai de diversas crianças desaparecidas, me resolvo a entregar à voracidade branca de uma folha de papel, minhas comovidas locubrações de última vontade.

Hoje posso cantar alto a Viúva Alegre em minha casa, tirar meleca do nariz, peidar alto! Posso livremente fazer tudo o que quero contra a moralidade e a decência. Não tenho mais satisfações a dar nem ao Carlindoga nem a Lalá, diretores dos rendez-vous de consciências, onde puxei a carroça dos meus deveres matrimoniais e políticos, durante vinte e dois anos solares!

Recquiescat oh ex-vaca leiteira que Deus e a Sociedade fizeram a mãe de meus filhos! Recquiescant castrados da Repartição que diariamente me chamavam de "Chocolate com ovos"!

Nem um cão policial nas ruas encarvoadas. Apenas um gozo voluptuoso de pólvora penetra das ruas que escutam como narinas fechadas por essas janelas afora! (Andrade, 2007, p.95)

Se, por um lado, a noção de "jogo" pressupõe conhecimento das regras e adesão às mesmas por parte dos participantes, por outro, o deslocamento, o inesperado, a informalidade ou a coloquialidade, e o rebaixamento, elementos da "afasia" (Andrade, 2007, p.48) oswaldiana, vão recorrentemente se constituindo na diretriz dessa obra, abalando, num primeiro momento, o pacto estabelecido entre 
os jogadores (emissores e receptores; autor, eu textual e leitor). Contudo, à medida que o "desregramento", numa espécie de efeito colateral, vai se tornando esperado ou previsível, ${ }^{4}$ ter-se-ia outra noção relacionada ao "jogo" - a de "fracasso" ou "perda" -, que, no projeto literário do autor, intensificaria a transposição: a inadequação de Serafim naquilo que é social e moralmente esperado relaciona-se direta e fortemente a uma inadequação que é também da língua, cujas palavras podem não se restringir aos sentidos esperados, cuja diversidade e cuja potencialidade são acentuadas em sua proficuidade ou em sua burla. Isso não se daria somente no nível microestrutural, como apontado por H. de Campos (2007), nas combinações dos vocábulos, nos deslocamentos semânticos, nas divisões ou nas rupturas das molduras ou dos gêneros textuais, na incitação do cômico ou do risível; homologicamente, na macroestrutura, Serafim Ponte Grande triunfaria em seu fracasso, constituindo-se num "grande não livro", ou seja, "[n] um livro compósito, híbrido, feito de pedaços ou "amostras" de vários livros possíveis, todos eles propondo e contestando uma certa modalidade do gênero narrativo ou da assim dita arte da prosa" (Campos, 2007, p.18).

Se, no contexto da literatura brasileira, o lúdico de/em Oswald de Andrade, moldado, sobretudo, na plenitude das vanguardas modernas, poderia caracterizar um primeiro trato com a materialidade, seria a partir de meados da década de 1940, com João Guimarães Rosa e com Clarice Lispector, que ele ganharia outro

4 A previsibilidade que pode advir do uso recorrente, por vezes incessante, de certos procedimentos ou de temáticas permite que se delineie um possível diálogo entre a obra de Andrade e a tradição. Tanto Serafim Ponte Grande quanto Leonardo-pai e, em particular, Leonardo-filho, de Memórias de um sargento de milícias, vagueiam pela inadequação àquilo que lhes foi imposto. Se, contudo, como aponta A. Candido (1993), Leonardo Pataca acaba se inserindo no sistema e em seus deleites, adequando-se sem maiores questionamentos, a volta ao lar de Serafim acentua, mais uma vez, o fracasso, o seu "anarquismo enrugado” (Andrade, 2007, p.194), a sua incansável capacidade de não se adequar, mesmo aparentando o oposto - uma das formas da reversão andradiana. 
dimensionamento, por potencializarem, sob vieses distintos, a corporeidade das personagens, dos espaços, da língua, em meio a oposições ou a homologias entre a exterioridade e a interioridade. Ao trazerem, respectivamente, o ritmado e justaposto encadeamento de vocábulos, sintagmas e gêneros literários/textuais, e a concepção de "dramatização" ou de "encenação" (Nunes, 1989) que contrasta a experiência e sua apreensão, Rosa e Lispector:

[...] retomaram o esforço de invenção da linguagem, coisa rara e perigosa, que quando dá certo eleva o perfil das literaturas [...] Para eles, o problema parecia consistir em obter um equilíbrio novo entre tema e palavra, de modo que a importância de ambos fosse igual. [...] Como para os dois romancistas do Modernismo dos anos Vinte, a palavra literária readquiria na prosa o seu status soberano. (Candido, 1996, p. XVIII)

Se em Oswald os primeiros movimentos de uma dramatização se davam, até com uma projeção do autor por vezes se fazendo ver de maneira veemente, seria com Clarice e Guimarães que o corpo textual passaria reiteradamente a se mostrar o grande palco onde se encena a saga de um sujeito e a da própria língua, numa tentativa de apreensão do real, da experiência, do verbo e de seus significados. É o caso de "Cara de bronze", integrante do volume Corpo de baile, publicado por Rosa em 1956, em que a revisitação do passado e a busca pela essência empreendidas pelo protagonista homônimo, um senhor à beira da morte, recluso em seu quarto e que almeja "o quem das coisas" (Rosa, 1976, p.101, grifo do autor), são concomitantes a uma singular e intensificada experimentação com os gêneros, as sequências e os registros:

No Urubuquaquá, não. Ali havia riqueza, dada e feita. A casa avarandada, assobradada, clara de cal, com barras de madeira dura nos janelões - se marcava. Era seu assento num pendor de bacia. Tudo o que de lá se avistava, assim nos morros assim a vaz, seria gozo forte, o verdejante. Somente em longe ponto o crancavão dum 
barranco se rasgava, de rechã, vermelho de grés. Mas, por cima, azulal, ao norte, fechava o horizonte o albardão de uma serra. No Urubuquaquá. A Casa, batentes de pereiro e sucupira, portas de vinhático. O fazendeiro seu dono se chamava o "Cara de Bronze". (Rosa, 1976, p.73)

Se em outros textos rosianos, como nos de Sagarana, de 1946, a focalização do narrador matizava um percurso que oscilava do exterior - as tão comentadas paisagens, os deslocamentos espaciais - ao interior - os conflitos, as vivências e as transformações por que passavam as personagens -, com o uso do discurso direto e, principalmente, do discurso indireto livre, em "Cara de Bronze" ela passa a ser deslocada de seu patamar tradicional e/ou demiúrgico, sendo entrecortada por uma série de sequências dialogais que colocam em conjunto todas as dimensões da corporeidade - a do texto e a do que é externo ao mesmo/ a do processo de criação; a da folha em branco ou do corpo do livro; a das Gerais; as das personagens, em especial os vaqueiros, que tanto fantasiam ou especulam a respeito dos fatos que levaram o velho senhor à referida condição:

\section{(A chuva.)}

Iô Jesuino Filósio: Ninguém sabe aonde esse Grivo foi? Não se tem ideia?

O vaqueiro Adino: É de ver... De certo, danado de longe.

O vaqueiro Tadeu: Nas Províncias...

O vaqueiro Cicica: Saiu daqui escoteiro, faz dois anos. Em tempo das águas.

Moimeichego: Tão lonjão foi?

O vaqueiro Manarte: Meava-se um janeiro... O Velho mandou. Chuvaral, desdizia d'ele ir. Mas o Velho quem quis. Nem esperou izinvernar, té que os caminhos enxugassem.

O vaqueiro Adino: Cara de Bronze, uê. Foi os mil macacos!

O vaqueiro Sãos: De mim, bobagens... Acho que foi só no Paracatu que ele foi... 
Cantando, o CANTADOR:

Buriti, minha palmeira, toda água vai olhar.

Cruzo assim tantas veredas, alegre de te encontrar...

O vaqueiro Sãos (a Moimeichego): O senhor já esteve no Paracatu?

O vaqueiro Tadeu: Paracatu - cidade dos refúgios...

O vaqueiro Cicica: Bestagens. Seguiu em cima com rumo para um dos nortes: que levou bogó de carregar água e trajava terno todo de couro, modo de passar a caatinga alta... (Rosa, 1976, p.81 2, grifos do autor)

Nessa toada enredada no espaço exterior de texto e de contexto apresentados em seus pormenores, e no espaço interior, que é a toada do processo de criação e a que suscita tanto a experiência da personagem Grivo em suas andanças, designado a buscar pela essência, quanto o mudo conflito de Cara de Bronze, que, sempre à espera de seu subordinado, pouco aparece, configura-se um paradoxo que vai acentuando a tensão intransponível entre o "máximo" e o "mínimo", isto é, entre a rica transformação interior e a impossibilidade de transmiti-la aos demais, entre a profícua ou prolixa experimentação verbal e o silêncio. Dessa perspectiva, as notas de rodapé, que poderiam desempenhar mera função acessória ou secundária, saltam aos olhos por apresentarem uma marcação horizontal no território gráfico e discursivo, sugerindo uma sobreposição de corpos, discursos, vozes, espaços, temas - de uma complementação ou elucidação do enredo a um desdobramento de histórias e de vozes; de um trato referencial do narrador com os substantivos que traduzem a paisagem percorrida a uma almejada e onipotente apreensão da experiência e do gesto nomeador:

- E que as árvores, afora muitas, o Grivo pôde ver? Com que pessoas ele topou? 
A ana-sorte. $\mathrm{O}$ joão-curto. $\mathrm{O}$ joão-correia. As três-marias. $\mathrm{O}$ sebastião-de-arruda. O são-fidelis. $\mathrm{O}$ angelim-macho. $\mathrm{O}$ angelim-amargo. O joão-leite. O guzabu-preto. O capitão-do-campo. A bela-corista. O barabu. A gorazema. A árvore-da-vaca. A ciriba. A nhaíva. O oiti-bêbado. O carvão-branco. O pau-de-pente. $O$ sete-casacas. A carrancuda. O triste-flor. O cabelo-de-negro. O catinga-de-porco. A carne-de-anta. O bate-caixa. A bolsa-de-pastor. A chupa-ferro. O gonçalo-alves. A casca-do-brasil. O calcanhar-de-cutia. O jacarandá-mimosim. A canela-atoa. A carne-de-vaca. A rama-de-bezerro. A capa-rosa-de-judeu. A maria-pobre. A colher-de-vaqueiro. O jacarandá-muxiba. $\mathrm{O}$ grosso-aí. A combuca-de-macaco. O pente-de-macaco. O macaqueiro. A árvore-de-folha-parida. $\mathrm{O}$ castiçal. $\mathrm{O}$ malmal. $\mathrm{O}$ frei-jorge. A cachaporra de gentio. $\mathrm{O}$ açoita-cavalos. $\mathrm{O}$ amansa-bestas. O rosa-do-norte [...] (Rosa, 1976, p.108, grifo do autor)

- Dito completo?

- Falta muito. Falta quase tudo.

(Do que certo viu. Os gravatás tantos. O angelim - a altíssima! $\mathrm{O}$ angico-vero, sempreflóreo. O mamoeiro-bravo, obtruso. A barriguda em vernação: a barriguda, sementes leves. O belo jenipapeiro versiforme. A lobeira, cimátil, que se inventou um verde. E a caraíba - gnomônica.)

- Dos verdes viventes, cada um, por chuva e sol, pelejando no seu lugarim?

Tanto também não falou de outras árvores: desde o cedro que está no Líbano até ao hissopo, que nasce nos paredões... (Rosa, 1976, p.111, grifos do autor)

Esse trecho citado, que traz as primeiras e as últimas linhas de uma nota de rodapé que se estende ao longo de quatro páginas, imprime no corpo do texto/do livro um rico repertório de vozes justa e sobrepostas, marcando não apenas um abalo da estrutura narrativa, mas também a concomitância de temas, espaços, tempos. Esse recurso aponta: 
A diversidade de temas e faturas ancorada no desenredo [que] revela-se constante em Corpo de baile, variando, apenas, seus meandros de composição. "Cara de Bronze", por exemplo, constitui um trabalho em que as formas literárias se mesclam quase vertiginosamente: em meio a aspectos narrativos, líricos e dramáticos - representados por coplas, cantigas, recitações, ladainhas e amplos diálogos - aflora um roteiro que funciona como "quadros de montagem" ou de "filmagem" (p.92), ao lado de instruções técnicas - espécie de didascália fornecida a atores - e notas de rodapé que rompem a linearidade da leitura, obrigando-nos a acompanhar, simultaneamente, a ficção e o seu fazer artístico. (Galvão, 2001, p.27, grifos do autor)

Esses procedimentos, que não deixam de revisitar o próprio estilo do autor, acentuando ou reformulando tendências de outras obras suas, ${ }^{5}$ também potencializam aquele paradoxo, numa espécie de radicalização em abismo do "lance" mallarmiano. As notas de rodapé comportariam, assim, um desejo até obsessivo do autor ou do eu textual pela apreensão do real, ou um didatismo que poderia alegorizar a extensão dos caminhos percorridos por Grivo e a sedimentação de suas experiências; e, naquilo que poderia ser um excesso, elas explicitariam justamente a condição falaciosa desse desejo ou gesto nomeador, pois, afinal, "falta quase tudo" (Rosa, 1976, p.111).

5 E. Nascimento (1997) mapeia o processo de criação rosiano, destacando os procedimentos de registro empregados pelo autor e aqueles relativos aos mecanismos de produção de sentidos e de funcionamento da língua portuguesa e, em certos casos, de outras línguas. Entre eles estão: "termos da flora, [...] da fauna, $[\ldots]$ do folclore, $[\ldots]$ populares, brasileirismos, termos eruditos, $[\ldots]$ arcaicos, [...] técnicos, xenismos, regionalismos, expressões, provérbios, textos" (Nascimento, 1997, p.73-4). Observa, ainda, "os processos ou as matrizes morfológicas utilizados por ele para burlar a norma vigente atualizar novos vocábulos $[\ldots]$ : derivação sufixal, $[\ldots]$ de palavras compostas, $[. .$.$] regressiva -$ nominal, prefixal, composição [por] justaposição, aglutinação, parassintetismo, onomatopeia, reduplicação, abreviação, anagrama, associação paradigmática" (Nascimento, 1997, p.76). 
Ter-se-ia, novamente, o fracasso, que nesse texto de Rosa seria atrelado tanto a uma reiterada referencialidade quanto a uma experimentação poética que não deixariam de rearticular o "exagero verbal” (Fonseca, 2008, p.130) oswaldiano. A pulsação verbal, sonora e plástica, que foi eleita pela fortuna crítica como um dos principais matizes da produção rosiana, por meio do lúdico performa o desnível entre a máxima significação ou apreensão e sua impossibilidade ou seu fracasso - paradoxo também desenrolado na produção lispectoriana. Se, em Guimarães Rosa, a relação por vezes homológica entre exterioridade e interioridade fomenta a saga de toda uma gama de personagens pelo espaço das Gerais e pelo da palavra em seu intuito nomeador, é com Clarice Lispector que o silêncio e a frustração vão paulatinamente adquirindo não apenas uma indagação existencial, mas também um acentuado tom irônico e autocorrosivo que marcaria, principalmente, sua produção das décadas de 1960 e 1970. Note-se, por exemplo, em que medida aos recursos empregados em textos como "Amor", de Laços de família, de 1960, foram somados outros que amplificaram o lúdico paradoxo entre o máximo e o mínimo:

Não havia como fugir. Os dias que ela forjara haviam-se rompido na crosta e a água escapava. Estava diante da ostra. E não havia como não olhá-la. De que tinha vergonha? É que já não era mais piedade: seu coração se enchera com a pior vontade de viver. (Lispector, 1993, p.38)

O percurso do narrador onisciente entre o fora e o dentro, ora se aproximando, ora se distanciando da protagonista Ana, que leva o receptor a um cinematográfico deslocamento pelos bairros do Rio de Janeiro e pela interioridade da personagem, sobretudo pela gradação de discurso direto, indireto e indireto livre, junta-se a outras estratégias que intensificam esse jogo opositivo e que caracterizam o culminar de uma gradativa experimentação com os gêneros, as molduras textuais e os registros linguísticos. Não é sem razão que foram lançadas num mesmo período $A$ paixão segundo $G$. $H$., que na suspensão de seu início e de seu fim, dada pelo uso dos 
travessões, ciclicamente corporifica a (tentativa de) apreensão ou perquirição da existência e do verbo, e A legião estrangeira, que em sua hibridez original traz o rico "Fundo de gaveta", cuja abertura em muito aprofunda e performa a reversão da moldura prefacial sugestionada em Serafim Ponte Grande:

Esta segunda parte se chamará, como uma vez me sugeriu o nunca assaz citado Otto Lara Resende, de "Fundo de gaveta". Mas por que livrar-se do que se amontoa, como em todas as casas, no fundo das gavetas? Vide Manuel Bandeira: para que ela me encontre com a "casa limpa, a mesa posta, com cada coisa em seu lugar". Por que tirar do fundo da gaveta, por exemplo, "a pecadora queimada", escrita apenas por diversão, enquanto eu esperava o nascimento de meu primeiro filho? Por que publicar o que não presta? Porque o que presta também não presta. Além do mais, o que obviamente não presta sempre me interessou muito. Gosto de um modo carinhoso do inacabado, do malfeito, daquilo que desajeitadamente tenta um pequeno voo e cai sem graça no chão. (Lispector, 1964, p.127)

Se, no escritor modernista, a jogralidade trazia à tona a transposição, iluminando o polo oposto, em Lispector a tensão se dá por meio do quiasma, em cuja estruturação um elemento se reverte no seu contrário simultânea e ininterruptamente, sem reduções ou aprisionamentos - é assim que "o que presta também não presta". ${ }^{6}$

6 N. Gotlib (1988) e O. de Sá (1993) analisaram esse processo na produção clariciana. Em Uma aprendizagem ou o livro dos prazeres, no qual a relação amorosa entre Ulisses e Lóri é também uma relação de e por meio da linguagem, a primeira estudiosa reconheceu esse procedimento, afirmando que: "Trata-se da série dupla, de contrários invertidos, [...] como o desenho de um $\mathrm{X}$, o 'X' da questão, que tem no vértice o seu 'ponto crítico'. Uma imagem é a predominante; e é o simulacro da outra, o seu reflexo invertido. Uma subverte a outra. E tende a dominá-la, assumindo o plano da predominância. Jogo de imagens. Jogo de poder de imagens. Jogo de sedução. Dos homens em relação às mulheres e vice-versa: devoração. Destes, em relação às linguagens com ou sem sentido: decifração" (Gotlib, 1988, p.19). 
É por meio desse processo paradoxal que a figura ou a voz do autor, ou daquele que narra, é reiteradamente projetada no texto, redimensionando o deslocamento em relação à realidade ou ao referente visto em Oswald, corroborando uma profunda ficcionalização que faz emergir a atuação ou a encenação de quem detém a palavra, bem como seus possíveis mascaramentos - uma escritora em crescente aclamação, uma mãe, uma chefe de família, uma mulher de classe média, uma mulher que não quer, não é ou não pode ser compreendida.

Tal como numa das voltas de uma espiral, o jogo entre o sério e o cômico, entre aparência e essência, visto na literatura brasileira do começo do século, chega com Clarice a um ponto fundamental, em que a autocorrosão metalinguística problematiza, inclusive, a voz de quem narra, inserindo-a no fluxo quiasmático de realidade e imaginação, crença e descrença, aproximação e distanciamento, texto e contexto. Paradigmáticos disso são "A língua do "p" e "Antes da ponte Rio-Niterói”, de A via crucis do corpo, de 1974, em que uma aparente objetividade ao apresentar trágicas e cotidianas histórias de desejo, amor e traição revela(-se) algo mais profundo, isto é, uma lúdica, "confusa" e profícua reflexão a respeito do contar e de seus possíveis desdobramentos, como o do esperado papel ou lugar do artista ou da arte. Observem-se os primeiros parágrafos desse segundo texto:

\section{Pois é.}

Cujo pai era amante, com seu alfinete de gravata, amante da mulher do médico que tratava da filha, quer dizer, da filha do amante e todos sabiam, e a mulher do médico pendurava uma toalha branca na janela significando que o amante podia entrar. Ou era toalha de cor e ele não entrava.

Mas estou me confundindo toda ou é o caso que é tão enrolado que se eu puder vou desenrolar. As realidades deles são inventadas. Peço desculpa porque além de contar os fatos também adivinho e o que adivinho aqui escrevo, escrivã que sou por fatalidade. Eu adivinho a realidade. Mas esta história não é de minha seara. É 
de safra de quem pode mais que eu, humilde que sou. Pois a filha teve gangrena na perna e tiveram que amputá-la. Essa Jandira, de dezessete anos, fogosa que nem potro novo e de cabelos belos, estava noiva. Mal o noivo viu a figura de muletas, toda alegre, alegria que ele não percebeu que era patética, pois bem, o noivo teve coragem de simplesmente desmanchar sem remorso o noivado, que aleijada ele não queria. (Lispector, 1998, p.57-8)

Desde seu início, "Antes da ponte Rio-Niterói” é marcado por dois movimentos em torno da relação entre realidade e imaginação: um, no primeiro parágrafo, que indicia o olhar da narradora em direção à sua recepção, e que numa espécie de "constatação" ou de proximidade fática simula uma maior proximidade com o leitor. Outro, a partir daí, que ressalta o ato da "escrivã por fatalidade" em coser relato e invento, "complicando" o "descomplicado", abalando essa aparente proximidade com os sujeitos e a matéria verbal.

A ruptura com a ordem tradicional do sintagma, dada, por exemplo, pelo pronome relativo "cujo" em seu início, alegoriza o processo de construção do texto clariciano em sua tecedura quiasmática: aquilo que seria simples ou descomplicado é também o seu oposto. Se o jogo com a língua se valia de uma quebra de expectativas de ordem semântica, como em Oswald de Andrade, ou de uma potencialização, que em certos casos poderia até parecer redundante ou ser paradoxal, como em Guimarães Rosa, em Clarice Lispector a ruptura é tanto de ordem sintagmática, na concatenação de fatos em relatos, quanto paradigmática, numa visada autorreferencial na corporeidade de personagens e na da palavra. É dessa maneira que suas produções do final da década de 1960 e, sobretudo, dos primeiros anos da década de 1970 trazem uma série de protagonistas em contato com as vertigens ou os limites do verbo e de seus corpos, caracterizando uma experimentação lúdica que ilumina não somente a transformação ou a profusão, mas também a ironia, o deslocamento, o fracasso, recolocando em cena o "Fundo de gaveta".

Nesse cotejo entre diferentes modulações textuais, desenrola-se, mais uma vez, um contraste entre a profusão e o cerceamento 
que ilumina um procedimento semeado desde os primórdios do último século, que foi adensado na obra desses autores e que viria à tona, num acirramento incisivo, no singular e profícuo caso de Hilda Hilst: a tensão entre a minimização da ação e a maximização do discurso, e, ainda, entre o inverso dessas. Adensando a espiral, Hilst insere quiasmas em quiasmas, promovendo o desdobramento de fatos e de significados que levam tanto à sobejidão ou à verborragia quanto à contenção, ao silêncio ou ao nada. Talvez a obra que melhor corporifique esse processo seja Ficções, de 1977, volume que reúne seus primeiros livros em prosa, Fluxo-floema, de 1970, e Qadós/Kadosh, de 1973, a textos até então inéditos, enlaçados pela denominação "Pequenos discursos. E um grande.", 7 e que dariam a medida poética da autora. Em sua composição, uma configuração se destaca de início: a que pontua cada texto em sua unidade ou em seu corpo, permitindo visualizar a tensão entre a inação e a ação, o vazio e o excesso, assim como suas reverberações, dadas especialmente pelo contato, por vezes irônico, por vezes veemente, do sujeito com a palavra, seja a do outro ou a sua própria, e com a sexualidade e o inumano. Tanto Fluxo-floema quanto Qadós/Kadosh são exemplares desse tateio, articulando em seus corpos-projetos certas marcações autorreferenciais: o uso de maiúsculas, de negrito ou de itálico, de diferentes tamanhos e tipos de letras, de línguas estrangeiras; a ausência de paragrafação; a concomitância de diferentes registros textuais, como discurso direto, indireto, indireto livre, rubricas e versos; a enumeração; as lacunas; as justaposições; os neologismos; os desenhos; as ilustrações; os diferentes espaçamentos. Algumas destas poderiam ser notadas, na forma de um jorro ou de um fluxo verbal, na relação que Ruiska, protagonista de "Fluxo", recluso entre o poço e a claraboia, estabelece com seu corpo e seus peristaltismos, as demandas internas e externas, como o ato de se expressar ou de escrever e a necessidade de corresponder a padrões, imposta

7 São eles: "O projeto”, "Gestalt”, "Esboço”, “Teologia natural”, "Amável mas indomável”, "Ad majora nato sum”, Vicioso Kadek”, "Lucas, Naim”, “Um cálido in extremis". 
em especial por seu editor, a quem chama de "cornudo", e por sua esposa Ruisis, sendo, supostamente, economicamente produtivo:

A mesóclise é como uma cólica no meio do discurso: vem sempre. E não só isso, a mesóclise vem e você fica parado diante dela, pensando nela, besta olhando para ela. Leva muito tempo para a gente se recompor. [...] Bem, não há nada como uma mesóclise depois da outra. Quando se está a salvo. Respiro fundo. Aquele que me cuspia na boca já se foi. Ainda bem. Ora bolas, o incognoscível. Aliso a minha batina preta de frisos vermelhos. Aliso com ternura, com doçura, com loucura. Seria bom se eu pudesse participar agora de uma cerimônia litúrgica muito solene, levantar a hóstia, não, não levantar a hóstia seria contemplar o incognoscível? Seria? Bem, isso é pouco, o bom é adentrar-se no incognoscível, confundir-se com ele, mas de qualquer jeito eu vou fazer uma cerimônia litúrgica a meu modo, nada de deitar na terra e abrir os braços e os dedos, nada de se deitar, levantar-me sim, estender as mãos para frente, depois para o alto, captar com as pontas dos dedos o fogo de cima, movimentar os braços como uma hélice, envolver-se de chamas, empurrar a chama para o peito e para o meio dos olhos. Estou pronto. Começo a sair de mim mesmo. É doloroso sair de si mesmo, vem uma piedade enorme do teu corpo, uma piedade sem lágrimas, é, Ruiska, teu corpo está velho, teus ombros se estreitaram, teu peito afundou, tu, com a tua matéria espessa, eu com a minha matéria escassa, eu atravessando as paredes, que alívio, eu no jardim, subindo no tronco, sentado nos galhos, eu me alongando como um peixe-espada, eu me tornando todas as árvores, todos os bois, as graminhas, as ervinhas, os carrapichos, o sol doirado no meu corpo sem corpo, sim, no meu jardim há vários bois, há vacas também, há um lago de água salgada cheio de peixe-espada, é bonito dizer isso um lago de água salgada cheio de peixe-espada, é mais bonito ser tudo isso, ser água, escorregadia, amorfa, ser o que a água é quando está dentro de uma coisa que é apenas, ser o rio, o copo, ser todos os rios, todos os copos o cornudo que me esqueça - ser leve, tatuado de tudo, tatuado de nada, ser o estilete, a mão, a tinta, a figura, ser um mitocôndrio, e 
não há dúvida que vocês não sabem o que é o mitocôndrio, o bom da biologia é saber por exemplo o que é o mitocôndrio, pegar o seu micrógrafo eletrônico e olhar o mitocôndrio, e vem a propósito o mitocôndrio porque estou no meu jardim e os plastídios verdes das plantas se parecem aos mitocôndrios, não se aborreçam comigo, pois quando se sai do próprio corpo o mitocôndrio fica uma coisa tão simples e é por isso que eu falo dele. (Hilst, 1977, p.187-8)

Se, à luz da tradição moderna, esses recursos traziam, ludicamente, o contraste entre opostos, como o preto da tipografia e o branco da página, na espiral hilstiana eles incitam mais do que a aproximação ou o contato, a própria penetração do vertical com o horizontal, do alto com o baixo - o que diferencia a produção hilstiana da de seus precursores ou contemporâneos. E isso se daria não somente quanto à temática, isto é, no questionamento do protagonista acerca do incognoscível e do escrever ou se expressar conforme padrões, ou na sua condição, que poderia evocar certo riso ou certa comicidade, como a sua referência à mesóclise; os registros linguístico-estilísticos e os recursos gráficos também dinamizam um esquadrinhamento da própria materialidade, como, na citação anterior, apontando a diferença estabelecida a partir do uso do ponto final, que suscita breves pausas, marcando o enredo, ou um aparente ou provisório entendimento, e do uso da vírgula, que, ao alegorizar a velocidade ou a fluidez, ressalta a perquirição de Ruiska e uma singular ascensão de seu espaço de reclusão. Assim, na intersecção do vertical com o horizontal, ao alongar-se, subir, atravessar, tornar-se, Ruiska volta-se à matéria de seu corpo e à da existência, estabelecendo um jogo tautológico entre o fora e o dentro, o real e sua tradução, a ação e a inação. Diferentemente do que ocorre em Rosa, nas andanças de Grivo, no encontro-toque dos corpos das notas de rodapé e do restante do texto, em Hilst, a busca de Ruiska se dá vertiginosamente tanto por entre o alto quanto pelo baixo, tanto pelo encadeamento, sugerido pelos vocábulos relacionados à água "escorregadia e amorfa" (Hilst, 1977, p.188), quanto por sua ruptura, dada a partir das reflexões acerca do mitocôndrio, 
pautadas pela referencialidade e por um voltar-se ao outro, à recepção, reencenando noutra escala, entre o riso e o grave, o esperado e o inesperado, a transposição andradiana.

$\mathrm{Na}$ espiral hilstiana, o ímpeto jogralista oswaldiano, que enseja um deslocamento em relação a um campo semântico ou a um paradigma, a prodigalidade rosiana, que suscita as infindas possibilidades de relação e de atribuição de sentidos, e a corrosão irônica e autorreferencial clariciana, que coloca em cena o corpo da palavra e o da personagem, configuram, num acirramento próprio, um movimento pendular que, ao penetrar no corpo da palavra e no da carne, parece não poupar nem a própria obra ou o projeto que se arquitetaria. É nesse sentido que, no decorrer de "Fluxo", Ruiska logo deixa de focalizar o mitocôndrio, voltando-se paulatinamente ao de dentro, ao incognoscível, desdobrando-se no anão, uma outra personagem, para posteriormente dirigir-se ao de fora, saindo com este pelas ruas. É desse modo que Qadós/Kadosh, personagem de um dos textos da obra homônima, vai lançando, num jogo ritualizado de aproximação e de distanciamento, inúmeras nomeações do divino, tocando a matéria verbal e a carnal, questionando padrões, repercutindo nos veios e nas fissuras, na coexistência de alto e baixo, o fluxo quiasmático: "O GRANDE OBSCURO [...] O SEM NOME, O SUMIDOURO, GRANDE CORPO RAJADO, CÃO DE PEDRA, MÁSCARA DO NOJO, O MUDO SEMPRE, SORVETE ALMISCARADO, TRÍPLICE ACROBATA" (Hilst, 1977, p.97).

É ainda nesse viés que Fiç̧ões, na tensão da micro com a macroestrutura e das obras que as compõem, revelariam uma concisão que singularmente caracteriza Pequenos discursos. E um grande., e que se relaciona a uma objetividade, que, na conflituosa coerência da produção hilstiana, não é a da tradição. É assim que essa referencialidade hilstiana se articula com o uso da perspectiva em terceira pessoa, como em "Teologia natural", abaixo transcrito:

A cara do futuro ele não via. A vida, arremedo de nada. Então ficou pensando em ocos de cara, cegueira, mão corroída e pés, tudo 
seria comido pelo sal, brancura esticada da maldita, salgadura danada, infernosa salina, pensou óculos luvas galochas, ficou pensando vender o que, Tiô inteiro afundado numa cintilância, carne de sol era ele, seco salgado espichado, e a cara-carne do futuro onde é que estava? Sonhava-se adoçado, corpo de melaço, melhorança se conseguisse comprar os apetrechos, vende uma coisa, Tiô. Que coisa? Na cidade tem gente que compra até bosta embrulhada, se levasse concha, ostra, ah mas o pé não aguentava o dia inteiro na salina e ainda de noite à beira d'água salgada, no crespo da pedra, nas facas onde moravam as ostras. Entrou em casa. Secura, vaziez, num canto ela espiava e roía uns duros no molhado da boca, não era uma rata não, era tudo o que Tiô possuía, espiando agora os singulares atos do filho, Tiô encharcando uns trapos, enchendo as mãos de cinza, se eu te esfrego direito tu branqueia um pouco e fica linda, te vendo lá, e um dia te compro de novo, macieza na língua foi falando espaçado, sem ganchos, te vendo, agora as costas, vira, agora limpa tu mesma a barriga, eu me viro e tu esfrega os teus meios, enquanto limpas teu fundo pego um punhado de amoras, agora chega, espalhamos com cuidado essa massa vermelha na tua cara, na bochecha, no beiço, te estica mais pra esconder a corcova, óculos luvas galochas é tudo o que eu preciso, se compram tudo devem comprar a ti lá na cidade, depois te busco, e espanadas, cuidados, sopros no franzido da cara, nos cabelos, volteando a velha, examinando-a como faria exímio conhecedor de mães, sonhado comprador, Tiô amarrou às costas numas cordas velhas, tudo o que possuía, muda, pequena, delicada, um tico de mãe, e sorria muito enquanto caminhava. (Hilst, 1977, p.12)

Não obstante, esse "enxugamento" - que, como se nota, vem por meio do encadeamento, com um uso produtivo dos sinais de pontuação, em especial da vírgula, de inversões do sintagma nominal combinações de adjetivos e substantivos -, articula-se a uma redinamização do mergulho perquiridor na "língua que não diz a palavra" (Hilst, 1977, p.4), oriundo de uma tentativa de traduzir a experiência de uma primeira pessoa, com recursos semelhantes 
aos de "Fluxo" e de "Qadós/Kadosh", vista nos outros textos de Pequenos discursos. E um grande., já ensejando um movimento aporético em que a concisão, até de uma maneira lúdica, experimental, aliar-se-ia à profusão, fomentando a relação entre o fluxo e a contenção, bem como seus desdobramentos.

Lidas na sequência em que foram apresentadas, as Ficções de Hilst delineiam percursos: um, cronológico, que deixa ver as modulações de sua produção praticada na década de 1970, e que se estenderia, em certo sentido, às vindouras; outro, na imbricação aporética da matéria e com a matéria, que se estende entre polos, do "escorregadio e amorfo" ao "arremedo de nada", do excesso ou cerceio, e que pontua o seu jogo de ostentação com corporeidade. É nesse sentido que o ludismo hilstiano, uma singular ostentação da e com a língua, relacionar-se-ia ao gozo, noção esta que envolve o mesmo dinamismo praticado em sua produção, explicitador dos opostos: de um lado, o prazer e o deleite oriundos da sedução e do toque no corpo da palavra, na carne; de outro, certa burla ou zombaria, que ao suscitar a dúvida ou a inadequação, põe em xeque a possibilidade de entendimento, permitindo a vertiginosa constatação do vazio, da falta, do fracasso ou da falência. Isso também se desenrolaria, por exemplo, em O caderno rosa de Lori Lamby, de 1990, em que a revisitação do lúdico pelos vieses da infância e da arte, e a reversão promovida nos últimos parágrafos descortinaria o jogo de ostentação e de sedução colocado em prática, num abissal desdobramento, por aqueles que detém a palavra, evocando, dessa maneira, tanto o riso, na constatação da simulação, quanto o sério, na constatação de que diante de um mercado consumidor ou, sugestivamente, de um narrador perverso, não haveria, aparentemente, saída. É dessa maneira que Ruiska, não abrindo mão do escrutínio das fissuras de seu corpo, da obra que tenta escrever e de seu lugar na sociedade, chega a uma situação em que a vertigem e o desdém, a ação e o desespero, suscitariam a singular condição de estar "frito" na "coexistência”, na "manteiga e no mijo" (Hilst, 1977, p.217).

Com Hilda Hilst chega-se, pois, a um ponto em que tanto a convergência revisitada dos lances lúdicos de seus precursores - como 
Oswald de Andrade, Guimarães Rosa e Clarice Lispector - quanto a divergência em relação aos de seus contemporâneos, como Valêncio Xavier, que os articula a outros elementos, são matéria a ser ainda explorada. Tanto numa direção quanto noutra, a produção hilstiana se torna referência por conjugar de maneira veemente e irredutível um "apego" ou um "investimento" na corporeidade da palavra e do sujeito que tanto aponta a revelação ou a vertigem, quanto constata a ironia, a falência, o fracasso e o vazio. Lidas conforme o contexto de sua elaboração e de seu lançamento, as Ficções hilstianas, reconfigurando seus antecessores, dariam margem à análise da relação entre interioridade e exterioridade e, assim, a um não menos perturbador "diálogo" acerca das relações entre tradição e inovação, bem como entre arte e sociedade, especialmente numa época em que o sistema ditatorial, em meio às suas próprias contradições, oscilava da opressão político-social à abertura ao capital estrangeiro, à capitalização.

\section{Referências bibliográficas}

ANDRADE, O. de. Serafim Ponte Grande. 9.ed. São Paulo: Globo, 2007. ÁVILA, A. O lúdico e as projeções do mundo barroco. São Paulo: Perspectiva, 1971.

CAMPOS, H. de. Serafim: um grande não-livro. In: ANDRADE, O. de. Serafim Ponte Grande. 9.ed. São Paulo: Globo, 2007, p.13-46.

CANDIDO, A. Dialética da malandragem. In: . O discurso e a cidade. São Paulo: Duas Cidades, 1993, p.19-54.

. No começo era de fato o verbo. In: LISPECTOR, C. A paixão segundo G. H. Edição crítica. 2.ed. Rio de Janeiro: UFRJ Editora, ALCA XX, 1996, p.XVII-XIX.

FONSECA, M. A. Por que ler Oswald de Andrade. São Paulo: Globo, 2008.

GALVÃO, W. N. O contar desmanchando... artifícios em Rosa. In: DUARTE, L. P; ALVES, M. T. A. (Orgs.). Outras margens: estudos da obra de Guimarães Rosa. Belo Horizonte: Autêntica, PUC Minas, 2001, p.21-35. 
GOTLIB, N. B. Três vezes Clarice. Papéis avulsos. Rio de Janeiro, n.7, 1988, p.21-35.

LISPECTOR, C. A legião estrangeira. Rio de Janeiro: Editora do Autor, 1964.

Amor. In: Laços de família. 25.ed. Rio de Janeiro: Francisco Alves, 1993, p.29-41.

Antes da ponte Rio-Niterói. In: A via crucis do corpo. Rio de Janeiro: Rocco, 1998, p.57-60.

HILST, H. Ficções. São Paulo: Quirón, 1977. Fluxo. In: Ficções. São Paulo: Quirón, 1977, p.181-217. . O caderno rosa de Lori Lamby. 2.ed. São Paulo: Globo, 1990. . Teologia natural. In: . Ficções. São Paulo: Quirón, 1977, p.12-3.

Qadós. In: Ficções. São Paulo: Quirón, 1977, p.45-176.

NASCIMENTO, E. M. F. S. O texto rosiano - documentação e criação. Scripta, Belo Horizonte, v.1, n.1, p.71-9, 1997.

NUNES, B. O drama da linguagem: uma leitura de Clarice Lispector. São Paulo: Ática, 1989.

ROSA, J. G. Cara de Bronze. In: . No Urubuquaquá, no Pinhém. 5.ed. Rio de Janeiro: José Olympio, 1976, p.71-127.

SÁ, O. de. Clarice Lispector: a travessia do oposto. 2.ed. São Paulo: Annablume, 1993. 


\title{
REFULGÊNCIA, DOR E MARAVILHA. OS CONCEITOS DE TEMPO, DETERIORAÇÃO, FINITUDE E MORTE NA OBRA DE HILDA HILST
}

\author{
Alva Martínez Teixeiro
}

Qui meurt a permission de tout dire.

(François Villon)

É um olhar para baixo que eu nasci tendo.

(Manoel de Barros)

Quando aprendi a morrer, não disse nada a ninguém.

(Nuno Ramos)

O tecido da escrita da autora paulista Hilda Hilst, que frequentemente privilegia o teor construtivo da linguagem como espelho e mecanismo indagador a respeito de diversas experiências metafísicas radicais, centra-se, em diversas obras, ao tratar o complexo universo literário da personagem ou da persona poética em crise, na indagação sem resposta a respeito da vida, que parece vazia de sentido, assim como da condição humana.

Situamo-nos, portanto, mais no domínio do metafísico do que no domínio do psicológico, onde a crise da personagem será aparentemente reorientada através dos momentos em que a unidade da consciência das personagens oferece certos instantes de iluminação que outorgam um novo sentido à realidade. 
Assim, na escrita da autora paulista o interesse no caráter humano é mais da ordem do metafísico. Dado que a psicanálise não é interessante para a sua produção literária, Hilst retrocede a outros modos de pensamento, como o misticismo ou uma subjetividade eminentemente lírica. E, para isto, a emergência desse particular herói na escrita hilstiana participa de algumas das tendências literárias renovadoras do século XX, sendo questionadas a unidade e a estabilidade que a literatura anterior concedia à personagem como entidade simples situada num esquema causal relativamente estável. A título de exemplo, podemos referir aquilo que a respeito da vocação metafísica do romance contemporâneo indicava Andrés Amorós na sua Introducción a la novela contemporánea (1985, p.52):

Este es el gran tema, el único asunto de la novela contemporánea importante: el problema del hombre, que encierra en sí todos los problemas. ¿Cómo es el hombre? ¿Cuáles son su destino y su libertad efectivas? ¿Tiene (todavía) posibilidades de salvación? ¿Qué se puede hacer para mejorar su condición? Unamuno, Malraux, Sartre, Bernanos, Graham Greene, Cortázar... Todos nos dan su personal respuesta a este problema. Intentan alcanzar un humanismo nuevo, puesto al dia, que parte del dolor y el fracaso, que no significa ya dominio del hombre sino piedad por el hombre.

Relativamente a essa problemática do ser humano, na obra Mal- estar na civilização, Freud indicava as fontes principais da aflição e do desconforto do homem contemporâneo; todas elas presentes, paradoxalmente, numa obra de forte subjetividade lírica como é a da escritora paulista: "as exigências imperativas do social, a degradação do corpo, a morte e os conflitos inerentes aos laços sociais" (Ferreira, 2004, p.11).

Aliás, se centramos a nossa atenção na biografia da maior parte dessas personagens hilstianas, poderíamos atingir uma visão de conjunto, dado que acabam por coincidir em muitos dos seus traços caraterizadores, como, por exemplo, a obscuridade existencial provocada pelo sentimento da degenerescência e o sentimento de 
morte, referidos por Freud, e consequência direta dessa indagação sem resposta a respeito da vida na escrita da autora paulista.

A essência do diferente, do invulgar ou mesmo do excêntrico em sentido lato deriva em figuras transgenéricas e transmodais presentes por igual na narrativa e na poesia - e também no teatro - e num conjunto de meditações que estrutura uma compreensão lúcida, mas impiedosa, a respeito da vida, centrada na ideia do desamparo do ser humano e que se ofrece ao leitor, implicitamente, como uma reescrita pertinaz e obsessiva:

[... ] não há limite nesse texto quanto aos assuntos: histórias, narrativas, filosofia, tudo se encontra no corpo do texto, em permanente diálogo, pois o que Hilst escreve é um só trabalho, e não vários como afirmaram alguns críticos. É preciso perceber a unidade coesa e coerente que configura suas narrativas, mesmo que para isso tenha-se que deixar sua obra ficcional solitariamente reservada no hall da literatura brasileira como um estilo singular criado por Hilda para se manifestar. (Dias, 2010, p.109)

Aquilo que abala as personagens, quebra todas as suas pequenas certezas e unifica, numa das vias possíveis, os discursos mais diversificados dentro da escrita hilstiana - também da poesia - é a ideia de que seu conhecimento resulta insuficiente para alcançar uma resposta satisfatória à pergunta sobre a existência de uma intencionalidade última para a vida humana: "tentar compor o discurso sem saber do seu começo e do seu fim ou o porquê de tentar situar-se é como segurar o centro de uma corda sobre o abismo e nem saber como é que se foi parar ali, se vamos para a esquerda ou para a direita" (Hilst, 2001, p.71-2).

A carência essencial acima manifestada pela Senhora D atrai, concentra e irradia as linhas de sentido de grande número de textos hilstianos, o que fomenta uma articulação discursiva uníssona da escrita.

Nela, a tragédia deriva do convívio no espírito das diversas personagens da disposição ao pessimismo e do seu contrário, isto é, da 
tendência ao inconformismo que os situa numa luta por atingir uma compreensão metafísica e/ou uma transcendência que, já de início, pressentem agônica:

La existencia es trágica por su radical dualidad, por pertenecer a la vez al reino de la naturaleza y al reino del espiritu: en tanto que cuerpo somos naturaleza $y$, en consecuencia, perecederos y relativos; en tanto que espíritus participamos de lo absoluto y la eternidad. El alma tironeada hacia arriba por nuestra ansia de eternidad y condenada a la muerte por su encarnación, parece ser la verdadera representante de la condición humana y la auténtica sede de nuestra infelicidad. (Sábato, 1979, p.146)

A criação por parte da autora desses seres "mutáveis, imperfeitos" (Hilst, 2002b, p.147) permite-lhe abranger os dois extremos possíveis do ser humano: a glória e a decadência, a redenção e a perda, pois essas criaturas foram elevadas o necessário para intuir a precariedade e o absurdo da existência dos seres humanos, mas não para ultrapassá-los, como sublinha Alcir Pécora em sua aproximação ao último livro em prosa de Hilda Hilst: "Deus se parece com um literato precioso, cheio de vaidade, a gerar rabos de papel nos quais tropeçam as criaturas" (Pécora, 2006b, p.8).

De fato, a convicção manifestada pelo protagonista do absurdo da vida humana durante a narrativa é ainda complementada na obra Estar sendo. Ter sido pela apreciação análoga que, em molde poético, faz da existência - "Vittorio com máscara de Luis Bruma, que foi Apolonio, pai de Hillé” (Hilst, 2006b, p.112-3) -, num conjunto de composições reproduzidas no desfecho da obra e nas quais, entre outros pensamentos, o eu lírico manifesta a aflição provocada pela ausência da loucura que dá lugar "[...] à torpe lucidez / Ao nojo do existir / E do me ver morrer?” (Hilst, 2006b, p.113).

Ocasionalmente, existe por parte de certas personagens hilstianas a procura de consolo e esperança no território desconhecido do além - como é o caso, entre outros, de Osmo, que se pergunta: "quando morremos, morremos definitivamente ou é possível que 
exista uma outra realidade impossível de pensar agora? Impossível de pensar agora porque agora as nossas antenas vão até um certo ponto e depois não vão mais, eu sei que não estou dizendo as coisas com lucidez" (Hilst, 1977, p.229). No entanto, muitas das figuras presentes na escrita hilstiana são dominadas por esse referido sentimento de angústia e de abandono da parte de um Deus que, depois de permitir-lhes intuir o transcendente, interdita essa meta com a morte.

Estamos, em clara relação de consequência, perante uma literatura regida pela condição catastrófica, onde o pensamento da morte conduz a um dos problemas metafísicos fundamentais das personagens da escritora paulista: a inutilidade e o absurdo de umas vidas abandonadas à transitoriedade, à preparação para a morte, antecipada em todo momento pelo "Tempo-Morte" (Hilst, 2003a, p.74) que "passa com a sua fina faca” (Hilst, 2003a, p.72).

Submetidas ao férreo regime temporal, as personagens hilstianas manifestam uma consciência impiedosa da fugacidade e da exiguidade do tempo de que dispõem, como se nota no seguinte excerto do relato "O unicórnio":

Porque não há tempo, você sabe, nós pensamos que o tempo é generoso mas nunca existe muito tempo para quem tem uma tarefa. O Nikos, assim para te dar um exemplo, escreveu que quando ele encontrava um mendigo na rua, tinha vontade de dizer: me dá o seu tempo, me dá o seu tempo. Só isso é que ele pensava quando encontrava um mendigo na rua? Às favas com o teu Nikos. (Hilst, 1977, p.269)

Aliás, essa perceção da insuficiência da duração da vida humana funciona como poética do desfecho do percurso ficcional da prosa hilstiana com o romance Estar sendo. Ter sido. O princípio de finitude, o julgamento e o posicionamento niilista dominam o pensamento de Vittorio, o protagonista - instalado na velhice e, portanto, já iniciado na lutuosa sabedoria própria da mesma -, quem se pergunta a respeito do sentido da vida: "afinal fomos feitos pra quê, 
hein? afinal você aprende aprende, quando está tudo pertinho da compreensão, você só sabe que já vai morrer. que judiaria!" (Hilst, 2006b, p.121).

A mesma perspetiva literária norteia a leitura da novela Com os meus olhos de cão, onde a convicção do protagonista a respeito do absurdo da vida baseia-se no princípio de que "O logos é isto: dor velhice-descaso dos mais vivos, mortos logo mais" (Hilst, 2006a, p.49).

Como vemos, o imperativo ético que domina as personagens apesar de sua desconformidade geral - é o de não negar o desengano da vida. Consequentemente, vários estratos da perceção temporal são expostos na obra da autora, quando as diferentes personagens percebem a angustiosa leveza de sua duração. Se a reflexão sobre o tempo alicerça muitos dos textos hilstianos, noutros encontraremos só a conclusão dessa desassossegante ponderação como fundo de meditações de diferente teor, como é o caso das composições de temática amorosa dos Cantares de perda e predileção - onde o topo do tempus fugit preside um simbolismo dominado por calendários e retratos - ou de certos poemas da obra inspirada na tradição lírica amorosa Júbilo, memória, noviciado da paixão, onde a angústia em face do absurdo é manifestada através de uma forte subjetividade lírica que reclama ao amado a "brusca despedida" e o esquecimento: "Do tempo / As enormes mandíbulas / Roendo nossas vidas" (Hilst, 2003b, p.79).

Contudo, e como já indicamos, o topo do tempus fugit adquire maior relevância e interesse no discurso das personagens cadaverizadas, instaladas no fim da vida - real ou antecipado -, pois a velhice é a imagem do homem cindido da divindade pela sua mesma natureza humana.

Assim, Vittorio é acompanhado no sentimento de decrepitude, próximo daquele mostrado pelos pintores barrocos, por um conjunto de personagens como Hillé, que participa da paradoxal experiência de "estar sendo" e, ao mesmo tempo, "ter sido" ao perguntar-se "como foi possível ter sido Hillé, vasta, afundando os dedos na matéria do mundo, e tendo sido, perder essa que era, e ser 
hoje quem é?" (Hilst, 2001, p.24) -, ou Lucas, protagonista do relato "Lucas, Naim", que aborda o tema de sua própria decadência por meio do expressionismo e de toda a sua dureza formal:

[... velhice era coisa de longe, de vazio, aderência de outro não de mim, bochechas magras, franzimentos, um acorpar-se de névoa e de suspiros, velhice hoje é perto e adequada a mim, estou aqui trançado, velhice Lucas, reconsidero a cara e tudo o mais diante do espelho, sou eu Lucas ainda, meio amarelo, e neste instante acorrentado à loba. (Hilst, 1977, p.23)

Não obstante, uma das reflexões mais impiedosas e lúcidas a respeito do absurdo da condição humana dominada por um tempo indiferente surge numa consideração extrínseca ao problema da velhice. Em “Tadeu (da razão)", primeira parte de Tu não te moves de ti, o desvairado e delirante protagonista começa a visitar uma casa que funciona como centro geriátrico, onde vivem "os velhos, aqueles que são difíceis de guardar no quarto, de emparedar" (Hilst, 2004b, p.31). Da observação demorada e reiterada dos anciãos em suas visitas, fica na mente de Tadeu uma trágica suspeita em relação à incapacidade do homem de assumir plenamente o absurdo da vida:

Em todos há uns ares de pequeno disfarce, alisam simultâneos o dorso do cão, será por que a pergunta traz no corpo mergulhadas, as palavras Tempo e Duração? Eternidade e seu corpo de pedra e dentro desse corpo o tempo procaz, insolência soterrado na carne. (Hilst, 2004b, p.40)

A compreensão de que "a imaginação sexual é sobretudo dissimulação do medo da morte” (Pécora, 2006b, p.8) será a que leve a autora a declinar também no âmbito da sexualidade a vivência da velhice.

A diversa natureza das ações perante o limite da morte assinala nesta vertente do tema uma divisão essencial no que diz respeito às 
personagens. Assim, por exemplo, deparamo-nos com Hillé e o seu já referido culto à infecundidade, que nega o corpo e a sexualidade no âmbito profano em favor do erotismo místico e das preocupações metafísicas:

E apalpava, escorria os dedos na minha anca, nas coxas, encostava a boca nos pelos, no meu mais fundo, dura boca de Ehud, fina úmida e aberta se me tocava, eu dizia olhe espere, queria tanto te falar, não, não faz agora Ehud, por favor, queria te falar, te falar da morte de Ivan Ilitch, da solidão desse homem, desses nadas do dia a dia que vão consumindo a melhor parte de nós, queria te falar do fardo quando envelhecemos, do desaparecimento, dessa coisa que não existe mas é crua, é viva, o Tempo. (Hilst, 2001, p.18)

Por oposição, Agda procura alívio da agonia causada pela degenerescência manifestada pela flacidez, pelos nódulos varicosos e por uma memória também pesada num tenso e barroco jogo entre o narcisismo e a caducidade, semelhante ao retratado por Clarice Lispector no conto "Mas vai chover".

Como Maria Angélica de Andrade, Agda tem um amante jovem e assalariado. Mas, enquanto a sexagenária protagonista clariciana não se importava com o "nojo" e com a "revolta" de seu amante de 19 anos - até que ele a abandona - e "dava gritinhos na hora do amor" (Lispector, 1998, p.77), pois estava cega pelo amor que sentia por ele, Agda não consegue distanciar-se da consciência da decrepitude, preocupada porque o amante "dirá aos amigos a velha gania nas minhas mãos", depois de tocar com a "mão ensolarada sobre o meu corpo de sombra" (Hilst, 1977, p.52).

A autora, para revelar a perceção agônica e mortal dessas personagens, aproveita o "férreo nexo que el pecado edénico establece entre la sensualidad, el tiempo y la muerte" (Argullol, 2007, p.72). Trata-se de um erotismo apocalítico, desesperado, onde o sexo, como defendem Sade, Bataille ou Quignard, é vizinho da morte, procurando perturbar o leitor e promover sentimentos contraditórios de compaixão e repulsão. 
Como é facilmente percetível, na escrita hilstiana essa visão da sexualidade apresenta crueza suficiente para que se instale nela o grotesco. A autora paulista parece partir do mesmo princípio aproveitado por Héléna Marienské - autora do romance Rhésus, que, sob um modo dionisíaco, apresenta o mesmo tabu da sexualidade através de desvairadas transgressões senis, como a presença de um mono gerontófilo que gera o conflito num geriátrico - para aproveitar o seu avesso: "le jeunisme qui formate la société postmoderne a un versant libidinal spectaculaire" [o culto à juventude que formata a sociedade pós-moderna tem um espetacular lado libidinal] (Marienské, 2007, p.39).

Contudo, é a escrita presente nos Contos d'escárnio. Textos grotescos a que revela uma maior proximidade do posicionamento literário adotado por Héléna Marienské, ao situar-se numa mesma procura literária de uma libertinagem provocadora por intermédio de Crasso, narrador e protagonista da obra, que inaugura a linhagem dos loquazes e devassos aristocratas hilstianos, continuada posteriormente pelos protagonistas das obras Cartas de um sedutor e Estar sendo. Ter sido.

Juntamente com a filiação à linhagem hilstiana da aristocracia libertina, surge nessa obra, portanto, um segundo princípio transgressor: a anômala condição do protagonista - mais do que sexuada, lasciva. Por oposição ao mundo carnavalesco que Lori, protagonista de O caderno rosa de Lori Lamby, representa - o mundo da sociedade contemporânea que, através da publicidade, da moda, das produções artísticas ou pornográficas, mostra como objetos de desejo o corpo de jovens muitas vezes próximas ainda da infância -, por oposição a esse modelo quimérico que regula o desejo contemporâneo e que representa um erotismo solar, Hilst opta por evocar nessa obra a sexualidade dos corpos transformados pelo tempo numa rebelião contra essa pulsão erótica consensual que adota a forma de um erotismo sombrio.

O protagonista agora é um homem de 60 anos que representa um tabu ainda vigente na contemporaneidade e que ele celebrará dilatadamente na escrita, através da lembrança da vida depravada 
da juventude - a respeito da qual manifesta, já significativamente, no início da obra: "só de pensar nisso, ainda agora, aos sessenta, minha pálida vara endurece um pouco" (Hilst, 2002a, p.17) - e da narração das suas senis transgressões.

Nessa provocadora exibição da sexualidade na vivência da velhice, Crasso é precedido e seguido por outras personagens, que se diferenciam dele, em maior ou menor medida, pela diversa natureza das suas ações perante o limite da morte, pois esta assinala uma divisão essencial entre Crasso e os outros, como os já referidos Agda ou Lucas.

Nesse erotismo apocalítico hilstiano, só o romance Estar sendo. Ter sido parece partir do mesmo princípio aproveitado por Hilst para os Contos d'escárnio. Textos grotescos. Sob o mesmo modo dionisíaco, o último romance da autora paulista recupera esse tabu sexual. Hilst situa-o numa zona indefinida entre a ironia e a provocação através de um protagonista - por vezes, divertido ainda com a memória das amantes - que, aliás, por causa do cinismo, aproxima-se, mesmo de modo explícito, da figura de Crasso:

Lucina antecipou-se, é apenas um bilhete. vejamos: "simpaticão, não gostarias de me convocar para um jus fruendi?" meu deus! convocar; jus fruendi. as coisas que me acontecem! a das coxas deve ser advogada até na cama. devo responder como? o ente dá sua anuência? (Hilst, 2006b, p.57-8)

Contudo, não devemos esquecer o fato de que Vittorio, diferentemente de Crasso, é dominado por uma consciência do tempo e da morte que o cadaveriza na espera do fim. Por isso, nessa genealogia de idosos protagonistas, talvez o paralelo mais evidente com a história de Crasso seja encontrado fora da escrita hilstiana, na obra $A$ casa dos budas ditosos.

O romance de João Ubaldo Ribeiro, arquitetado à volta da estratégia do manuscrito anónimo, alicerça-se também sobre as memórias sexuais de uma mulher idosa que, como a biografia de Crasso, constituem um "depoimento sócio-histórico-lítero-pornô" (Ribeiro, 1999, p.19). 
Embora a protagonista considere a velhice a partir de uma perspetiva negativa, em seu relato, como na obra hilstiana que analisamos, não existem indícios do erotismo apocalítico cultivado por Agda ou Lucas. Por isso, a narradora, cínica e irônica com a hipocrisia moral, deleita-se em sua provocadora evocação de uma vida devotada à "sacanagem" - recordemos que esse é um dos termos mais frequentes no romance - e à satisfação da luxúria, animada pela teoria de que teria nascido com um dom especial: as suas aptidões sexuais.

Partindo dessa mesma perspetiva e atitude memorialística, Crasso começará a irônica narração de seu "roteiro de fornicações" (Hilst, 2002a, p.30) que se arquiteta como um verdadeiro inventário de excentricidades sexuais. Esse registo minucioso e debochado inicia-se com a lembrança de Otávia, da qual recorda que "dizer Otávia na hora do gozo é como gozar com mulher e ao mesmo tempo com general romano" (Hilst, 2002a, p.15), e continua, no mesmo tom zombador, com a recordação de outras mulheres: "uma delas, trintona, Flora, advogada que tinha um rabo brancão e a pele lisa igual à baga de jaca, citava Lucrécio enquanto me afagava os culhões" (Hilst, 2002a, p.18).

Contudo, essa dimensão perturbadora acomoda-se definitivamente na obra graças à entrada de outra escrita mais obscura e complexa nas memórias de Crasso, a escrita de Hans Haeckel, um escritor sério que "havia escrito uma belíssima novela, uma nova história de Lázaro. A crítica o ignorava, os resenhistas de literatura teimavam que ele não existia, os coleguinhas sorriam invejosos quando uma vez ou outra alguém o mencionava" (Hilst, 2002a, p.40-1).

A obra dessa personagem, que se situa na infinidade de horizontes sobrepostos da multifacetada escrita do eu praticada pela autora - pois recordemos que a obra Fluxo-floema (1970) era conformada, entre outras, pela narração intitulada "Lázaro" - fascina o protagonista pela sua sensibilidade e sua estética trágica.

Destarte, Crasso decide reproduzir um texto de Hans - a quem, perante a vulgaridade e a indiferença do mundo contemporâneo, só lhe restara o suicídio - intitulado "Lisa". Trata-se de um conto que 
Crasso transcreve para o leitor e que é precedido do seguinte conselho: "Se quiser continuar vivo, pule este trecho" (Hilst, 2002a, p.43).

"Lisa" é, pois, uma narração aflitiva, agônica e perturbadora, alimentada talvez pela experiência pessoal do fenômeno de incompreensão e posterior autodestruição que dominara a existência do autor. Nele, mais uma vez recupera-se essa perceção agônica da existência, e portanto também da sexualidade, que imperava no entendimento de Agda ou Lucas, mas que, como já indicamos, não estava presente nas memórias sexuais de Crasso.

O relato de Hans mostra um episódio presenciado pelo narrador, morador de uma pensão onde uma noite vira como outro dos hóspedes, dono de uma macaca, Lisa, permitia que esta lhe acariciasse o sexo, enquanto o homem lamentava ser "apenas nós dois neste sórdido mundo de agonia e de treva” (Hilst, 2002a, p.45) e garantia ao animal: "Nunca o mundo me pareceu tão triste, tão aterrador, tão sem Deus” (Hilst, 2002a, p.45).

A influência da escrita de Hans provoca a partida de Crasso para a cidade do escritor morto, na procura de seus inéditos. Uma vez localizados, esses textos são reproduzidos, de modo parcial e disperso, na compósita obra. Essa cópia permite que a interpretação da realidade e do erotismo de Hans se revele como uma exibição da melancolia e do pessimismo modernos.

Essa demonstração niilista é organizada sob a forma de painel através da tragédia, apenas enunciada, do "tradutor, um homem que percebe a irreversibilidade do mal e enlouquece" (Hilst, 2002a, p.84), ou do laconicamente denominado "Conto de Hans Haeckel”, um relato brutal e alicerçado sobre a ideia da gratuidade da violência humana.

Sob a sombra do sofrimento, da compreensão da vida como um estado de luto permanente, Crasso é dominado por uma nova perceção da existência, pessimista e agônica, que se debate agora com sua anterior visão libertina e jocosa da vida. Essa consciência revelada alicerça-se à volta da imaginação da morte que dominava o relato "Lisa" e que, por um lado, provoca em Crasso a preocupação por "inventar algumas geringonças para serem colocadas no cére- 
bro dos nascituros impedindo que os homens tenham pensamentos deletérios. Saber da própria morte, por exemplo, é uma maçada" (Hilst, 2002a, p.81) ou, por outro lado, o desejo, mais adequado à sua condição libertina de que, "ao invés das bolinhas de algodão que usualmente colocam nas narinas do morto", Clódia "providencie bolinhas de pentelho de virgem” (Hilst, 2002a, p.79).

Vemos, portanto, como até o mais cínico dos narradores acaba por ser parcialmente dominado pela consciência da morte, desse absurdo da existência que subjuga um grupo numeroso de personagens hilstianas, pois, através do pensamento de Hans, o escritor maldito Crasso atinge a revelação que dota de lucidez inconformada e agônica essas personagens: "a vida é viável enquanto se fica na superfície, nos matizes” (Hilst, 2002a, p.85).

Aliás, essa mesma dimensão perturbadora acomoda-se na obra Cartas de um sedutor, o romance seguinte da denominada "série pornográfica” hilstiana, graças a um procedimento análogo: a presença, desta vez sobreposta, de outra escrita mais obscura e complexa nas memórias de Karl, o protagonista, nomeadamente, a escrita do seu avesso, Stamatius. Este, incapacitado para o suicídio pelo seu medo da morte, sobrevive numa realidade que lhe resulta alheia e perturbadora, como manifesta no espaço discursivo que partilha com o protagonista numa confusão entre as diferentes vozes narrativas e as máscaras do narrador.

Para poder sustentar-se, esse aristocrata reduzido à condição de mendigo, empobrecido por causa da sua "mania de ser escritor" (Hilst, 2004a, p.55), decide substituir o ensaio de escrita libertina pelo exercício de outras vertentes da literatura comercial.

Sucedem-se, assim, um conjunto de relatos que, afinal, não são mais do que manifestações literárias da agônica lucidez que já se adivinhava na figura de Karl, por exemplo, em seu medo da morte, "da pestilenta senhora” (Hilst, 2004a, p.56), ou em sua manifestação de um desconforto vital - "Os ossos. Os ovos. A sementeira. Essas coisas me vêm de repente num tranco. Ando cuspindo nas rodelas. Estou lixoso comigo mesmo e com o mundo" (Hilst, 2004a, p.65) muito próximo do verbalizado por Stamatius no início da obra: 
Como pensar o gozo envolto nestas tralhas? Nas minhas. Este desconforto de me saber lanoso e ulcerado, longos pelos te crescem nas virilhas se tu ousas pensar, e depois ao redor dos pelos estufadas feridas, ouso pensar me digo, a boca desdentada por tensões e vícios, ouso pensar me digo e isso não perdoam. (Hilst, 2004a, p.15)

A título de exemplo dessa impossibilidade de abandonar o desconsolo existencial em favor de assuntos mais superficiais e atrativos para o mercado literário, podemos referir um dos quatro relatos de Stamatius reproduzidos na obra, profundamente ligado à já referida atitude mantida por outros protagonistas hilstianos, como Agda.

Aconselhado por Eulália, a companheira na vida de mendicidade de Stamatius, quem lhe recomenda escrever "qualqué bestera" (Hilst, 2004a, p.85), este decide escrever o conto "Bestera", a história de uma anciã rica que, depois de todas as "reflexões sobre a sordidez, a ignomínia, a canalhice da humanidade" (Hilst, 2004a, p.88), decide beber e procurar homens para ter com eles relações sexuais pagas "antes de desaparecer na terra" (Hilst, 2004a, p.87).

Já na segunda parte das Cartas de um sedutor, intitulada "De outros ocos", a imagem de Stamatius, mediatizada através das suas tentativas literárias, cede o protagonismo à consciência dramática do escritor. Stamatius, movido pela recusa da banalidade contemporânea, reflete acerca da negativa e miserável condição humana.

O protagonista, sem progredir na elucidação dos mistérios da existência e dominado pela perceção sombria da vida, como antes o estivera Hans Haeckel, procura silenciá-la através de um relacionamento sexual agônico com Eulália, que tem como fundamento novamente uma concessão trágica do erotismo devida à adoção exclusiva do erotismo de morte. Na linha da interpretação do mesmo apresentada por Bataille, Stamatius procurará a negação do isolamento do eu, que só conhece o êxtase "excediéndose, trascendiéndose en el acto amoroso, en donde se pierde la soledad del ser" (Bataille, 1987, p.22).

Mais uma vez, o teor sexual da escrita fica em segundo plano, nesta ocasião por causa da ressurreição da condição nostálgica e 
desconfortável do protagonista no mundo, própria de muitas narrativas anteriores da autora.

Assim, como podemos observar, nesta vertente da obra hilstiana há um constante trabalho da escrita destinado a indicar que existem diferentes níveis de interpretação sob a apreciação mais imediata de um conjunto de obras realizadas com uma aberta - e historicamente documentada - intenção procaz e provocadora.

Contudo, na oscilação entre o eu libertino e inconsciente e um novo eu dotado de uma lucidez trágica, Crasso, quando menos, opta por negar a interioridade obscura, solipsista e sujeita à procura do sentido da existência, entrevista sob a influência de Hans, e por abandonar-se novamente ao superficial e à extroversão.

Por isso, no fim dos Contos d'escárnio. Textos grotescos, assistimos à recuperação literal da dimensão orgiástica da vida por parte de Crasso, que esquece a constatação da fatalidade do seu ser-em-trânsito em favor de um último exercício de frivolidade rococó.

A assistência de Crasso à festa de casamento dos príncipes Cul de Cul, dedicada à evocação do século XVIII, torna explícita a influência libertina subjacente no discurso da obra, ao introduzir os componentes de uma bacanal própria do Eros festivo desta tradição libertina - como a embriaguez, a fusão dos corpos ou a relação orgiástica com a natureza -, numa grande cena coral final.

O tópico da vanitas distorce-se, assim, neste singular retrato da vida como processo de decomposição e atinge uma zona indefinida, entre a risibilidade e o patético, que subverte a representação canônica do mundo para traduzir uma relação perturbada com o mesmo.

Outra manifestação possível dessa relação obscura com a realidade seria a da aguçada reflexão sobre a morte, originada pela angústia e que evidencia aquilo que Alcir Pécora denominara a "unidade do conjunto da obra de Hilda em torno da imaginação da morte” (Pécora, 2006b, p.9).

Com efeito, a presença da morte na escrita hilstiana é constante. Nesse sentido, a título de exemplo, podemos recordar a sua presença, quer por via humorística nas crónicas hilstianas, quer por 
via dramática, através da dialética amorosa exibida na obra Júbilo, memória, noviciado da Paixão, onde o eu lírico manifestava:
Meu medo, meu terror, será maior
Se eu a mim mesma me disser:
Preparo-me em silêncio. Em desamor.
E hoje mesmo começo a envelhecer. (Hilst, 2003b, p.32)

Por isso, por tanto pensar na morte, muitos dos protagonistas são personagens cadaverosas, como exemplifica o dictum de Ehud, marido de Hillé, que exemplarmente exclama que "ninguém está bem, estamos todos morrendo” (Hilst, 2001, p.24).

A par da perspectiva de Ehud, encontramos também outras personagens que constatam individualmente esse estado mórbido, tais como Haydum, um dos protagonistas do relato "Floema", que afirma não ter "entendimento com os vivos, sempre soube dos mortos" (Hilst, 1977, p.315), ou Lucas, o ancião protagonista de "Lucas-Naim", que na velhice indica:

Este tempo seria o de reflexão, de morte também, porque ainda que eu não esteja totalmente morto, estou à morte há muitos anos desde que resolvi olhar o que existia além, o descarnado de mim, ir lá adiante onde os outros paralisados aqui suspeitam apenas que há um pavoroso mais adiante. (Hilst, 1977, p.25)

Contudo, se nas obras em prosa da década de 1970 e de 1980 encontramos um aprofundamento evidente na consciência da morte, esta experimentará uma radicalização menos gradativa na poesia, onde tal temática encontra seu apogeu na obra Da morte. Odes mínimas (1980), apogeu, aliás, que na prosa não será atingido até a publicação de Estar sendo. Ter sido (1997), como é sabido, último volume em prosa da autora.

Enquanto a resposta geral perante o sentimento de morte tem correspondência com estados psíquicos como a angústia, mas também o medo - que, aliás, condizia com a atitude vital da própria 
autora, que afirmara numa entrevista aos Cadernos de literatura brasileira: "Eu tenho um pânico enorme da morte. Tenho medo de encontrar o desconhecido" (Lopez et al., 1999, p.38) -, nestas odes hilstianas a morte será matéria de observação, de interrogação e de enaltecimento através de um discurso que oscila entre a gravidade e a intimidade em sua particular articulação como interlocução dirigida à morte.

Nesse conjunto de poemas, um dos problemas mais agudos, mais equívocos e mais ponderados da produção hilstiana é considerado a partir de uma perspetiva nova e inesperada, pois o desconhecimento, o temor e a incerteza que a rodeiam são substituídos por uma abordagem positiva. O eu lírico secundariza as questões sem resposta definitiva a respeito da morte em favor de sua apreciação como única verdade provada, segura e incontestável da existência:

\author{
Me fiz poeta \\ Porque à minha volta \\ Na humana ideia de um deus que não conheço \\ A ti, morte, minha irmã \\ Te vejo. (Hilst, 2003a, p.60)
}

Por oposição à divindade, que se manifesta numa transcendência extrínseca e efêmera para o homem, a morte revela-se como uma realidade inamovível e imanente ao ser humano: "Um poeta e sua morte / Estão vivos e unidos / No mundo dos homens" (Hilst, 2003a, p.66).

Tudo isso favorece o interesse pela morte da parte do sujeito que, desta vez, à diferença de Haydum ou Lucas, se entrega persuadido ao estado mórbido e cadavérico de contemplação e, agora também, de interpelação da morte.

O eu lírico experimenta uma outra via de relacionamento com a onipresente morte centrada no afeto e que articula a imaginação da mesma num interessante desdobramento para o território amoroso, pois "não há nenhum horror na morte hilstiana que já não se tenha tornado uma companhia íntima na própria vida” (Pécora, 2003, p.8). 
Diante de uma relação suspensa entre o sujeito e a morte, o eu lírico adota uma imagética própria da tópica amorosa - e, frequentemente, sensual e erotizada -, para com ela transmitir, por meio da metáfora, o seu rol passivo - mas favorável - perante uma aliança inexorável:

Pertencente te carrego:

Dorso mutante, morte.

Há milênios te sei

E nunca te conheço.

Nós, consortes do tempo

Amada morte

Beijo-te o flanco

Os dentes

Caminho cadente a tua sorte

A minha. Te cavalgo. Tento. (Hilst, 2003a, p.31)

Nesse convívio assumido com a morte, o tópico do memento mori - tema recorrente, aliás, na escrita de outro grande escritor “espiritual” (Pires, 2002, p.101) brasileiro contemporâneo, Manuel Bandeira - avança para o imago mortis, para a figuração imaginada da morte, que se manifesta por meio de designativos como "Velhíssima-Pequenina" e "Menina-Morte" (Hilst, 2003a, p.40) ou "Cavalinha” (Hilst, 2003a, p.37), e que é complementada pelas aquarelas com que a própria Hilda Hilst transmitiu a particular visão da morte presente na obra.

Contudo, para a representação da morte mostrada nas aquarelas - integradas já na edição de Da morte. Odes mínimas de 1980, dos editores Massao Ohno e Roswitha Kempf, e recuperadas na edição de 2003 da editora Globo -, parece ser válida a afirmação de que "le figuration imagée de la mort, être de langage, se révèle impossible notamment parce que la peinture est un art de l'espace et que la mort se situe dans le temps" [a representação pictórica de morte, sendo de linguagem, se revela impossível, especialmente porque a pintura é uma arte do espaço e a morte se situa no tempo] 
(Picard, 1995, p.45), pois, com efeito, os desenhos não transmitem a espera expectante que domina durante toda a obra o sujeito lírico perante a natureza inexorável, mas suspensa, da morte. Mesmo assim, esses retratos complementam a fixação da ideia da morte da parte do sujeito ao dotá-la de uma nova dimensão. Enquanto a escrita introduz na reflexão uma dimensão essencialmente temporal, os desenhos - seguindo não só a reflexão de Michel Picard, mas também a clássica diferenciação de Gotthold Lessing entre as artes plásticas e a arte literária - oferecem como suplemento uma dimensão espacial, visual, que reforça a delicadeza e leveza com que, na obra, é examinada a realidade da morte e que é transmitida por Alcir Pécora (2003, p.8) na "Nota do organizador" que precede a sua edição:

As aquarelas são elucidativas e não devem ser desprezadas: têm todas cores quentes, vivas, e não apresentam nenhuma forma imediatamente reconhecível como fúnebre, temível ou macabra. As cenas são ensolaradas e apresentam cálidos passeios de seres que se metamorfoseiam em mistos e duplos. Certo primitivismo surrealista reforça a atmosfera exótica e onírica onde se indistinguem o próprio e o outro.

Retornando ao exercício nomeador que o eu lírico desenvolve na poesia de intimidade com a morte que os desenhos complementam, devemos indicar que os nomes - afinal articulados por volta do uso do eufemismo num dos âmbitos, o da morte, que privilegia esses "meios expressivos que adoçam a brutalidade" (Lapa, 1977, p.27)levam consigo a corporificação daquilo que se sabe inexorável, mas suspenso, e que funciona como alívio, partilhando essa perspetiva pouco macabra de que falava o professor Pécora a respeito dos desenhos, como preparação perante a incerteza mais definitiva: "Túrgida-mínima / Como virás, morte minha?” (Hilst, 2003a, p.33).

O tópico do imago mortis domina também o pensamento e o discurso do protagonista da obra que consideramos culminação da reflexão sobre a morte na prosa hilstiana, Estar sendo. Ter sido 
(1997). Vittorio, em face da "interlocução vitalista e prática das outras personagens” (Pécora, 2006b, p.8), afirma só pensar na morte, situado no impasse de "estar sendo" e já quase não ser, "ter sido". Por isso, no desenvolvimento do romance podemos observar essa personagem antecipando seu comportamento na hora da morte: "pois aí sim é que estás completamente acabado, inteirinho tu mesmo, nítido nítido, preciso, exato como um magnífico teorema, exato como... como o quê? um octaedro por exemplo" (Hilst, 2006b, p.46).

A morte iminente também será objeto de um poema composto pelo protagonista, onde, novamente, imagina a hora fatídica, ou do esboço que Vittorio traça de seu futuro túmulo numa carta à mulher, e que visualiza adornado por "talvez uma belíssima mulher com uma coroa de ônix na cabeça ou nas mãos..." (Hilst, 2006b, p.29), num posicionamento existencial análogo ao do protagonista do relato "Um cálido in extremis", que podemos identificar com o inefável, o "Todo-Um, o Sem-Nome" (Hilst, 1977, p.30). Este, perante a angústia que lhe provoca o saber-se responsável da brutal condição humana, vê seu juízo subjugado, igualmente, à imaginação da morte:

Morrer eu quero, placa inteiriça de marfim sobre o eu inteiro, antes da placa a esteira, aquela que nunca a teu alcance, nem de olhos fechados, KleineKu entenda, estou em agonia mas não vou morrer, deteriorado, informe, daqui para a frente pus e poeira avolumando-se, devo morar no silêncio, mas o de mim calado corre para ti. (Hilst, 1977, p.29)

Para Vittorio - como também para o protagonista de "Um cálido in extremis" a partir de uma diferente perspectiva -, a morte associa-se à frágil e incerta condição humana, como para a poetisa brasileira Lupe Cotrim Garaude, de quem Hilst reassume e transcreve um excerto de um poema de Obra consentida - na abertura de "Matamoros (da fantasia)", segunda parte de Tu não te moves de ti-, e que, em "Paisagem da análise" esclarece: 


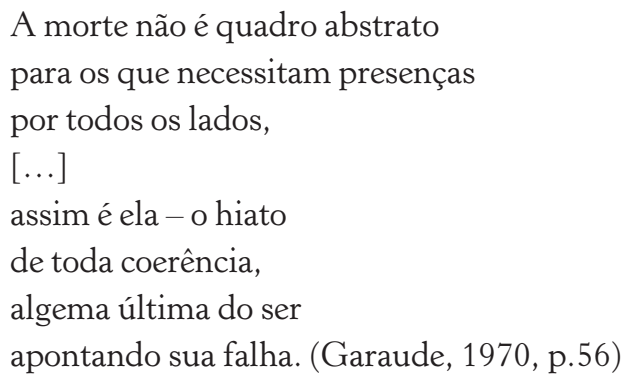

O conjunto de intuições a respeito da precariedade e do absurdo da existência humana, experimentadas pelas desvairadas personagens hilstianas, gera toda uma escrita e uma visão da realidade abissal e obscura, por volta da natureza "egocêntrica" do homem, que se manifesta não apenas no plano psicológico, como também no filosófico: "não lhe é possível conceber o universo, como sabem os filósofos, a não ser projetando sobre ele a sombra de seu pensamento" (Prado, 1987, p.84).

Assim, as obras aqui analisadas alicerçam-se, como as outras produções literárias da autora, numa vontade crítica preocupada com a condição humana e com a cegueira da sociedade moderna para perceber os verdadeiros problemas do homem satisfeito com a sua superficialidade, centrada agora nos conceitos de tempo, deterioração, finitude e morte.

Portanto, a presença desses dois aspetos em obras tão diversas como Júbilo, memória, noviciado da paixão ou Contos d'escárnio. Textos grotescos confirma como a obra hilstiana, em permanente diálogo, pode ser entendida - na esteira do indicado por Juarez Guimarães Dias - como uma unidade, ao mesmo tempo que invalida a rígida distinção estabelecida entre "a obra dita séria de Hilda Hilst e a sua obra dita pornográfica" (Pécora, 2006a, p.6), que a própria autora escarnecia, como quando uma das personagens da peça de teatro "O Pétala" - reproduzida no texto de Crasso - afirma que se tratava de "uma peça burlesca [...], ou você acha que o pessoal quer a HH, aquela metafísica croata?” (Hilst, 2002a, p.75), ou, igualmente, ao perguntar Clódia, páginas depois, se o texto de Hans era “metafísica ou putaria das grossas” (Hilst, 2002a, p.78). 
Esta breve análise de diversas obras permite-nos, assim, comprovar como a divergência entre esses dois momentos da escrita hilstiana residiria unicamente na mudança do ponto de vista quanto aos mecanismos de exame e questionamento a respeito do sentido da vida. É por isso que podemos concluir que as duas perspetivas de abordagem da temática da degenerescência e da morte são complementares, funcionando, mesmo, o olhar mais "debochado" como elemento radicalizador dos princípios já contidos nas obras anteriores, sendo possível afirmar com Alcir Pécora que se trata de uma "aposta existencial, desde o início meio perdida, contra a naturalização moralista da boçalidade” (Pécora, 2004, p.8). Uma assunção que os protagonistas condenam, a partir de uma posição extrema e aristocrática, próxima, por vezes, do sarcasmo mais cáustico a respeito da sociedade, através de uma técnica que, como vemos, consiste em estimular, desde o interior da ficção, o debate das ideias, aproveitando, em primeiro lugar, a hipocrisia da sociedade para fundamentar a censura contra a cegueira contemporânea.

\section{Referências bibliográficas}

AMORÓS, A. Introducción a la novela contemporánea. 8.ed. Madrid: Cátedra, 1985.

ARGULLOL, R. El fin del mundo como obra de arte. Barcelona: Acantilado, 2007.

BATAILLE, G. La literatura y el mal. 2.ed. Madrid: Taurus, 1987.

DIAS, J. G. O fluxo metanarrativo de Hilda Hilst em Fluxo-floema. São Paulo: Annablume, 2010.

FERREIRA, N. P. A teoria do amor. Rio de Janeiro: Jorge Zahar Editor, 2004.

GARAUDE, L. C. Poemas ao outro. São Paulo: Conselho Estadual de

Leitura, Comissão de Leitura, 1970.

HILST, H. Ficções. São Paulo: Quíron, 1977.

A obscena senhora D. São Paulo: Editora Globo, 2001.

Contos d'escárnio. Textos grotescos. São Paulo: Editora Globo, 2002a.

Exercícios. São Paulo: Editora Globo, 2002b. 
HILST, H. Da morte. Odes mínimas. São Paulo: Editora Globo, 2003a. Júbilo, memória, noviciado da paixão. São Paulo: Editora Globo, 2003b.

. Cartas de um sedutor. Lisboa: Campo das Letras, 2004a. . Tu não te moves de ti. São Paulo: Editora Globo, 2004b. . Com os meus olhos de cão. 2.ed. São Paulo: Editora Globo, 2006a. Estar sendo. Ter sido. 2.ed. São Paulo: Editora Globo, 2006b.

LAPA, M. R. Estilística da língua portuguesa. 9.ed. Coimbra: Coimbra Editora, 1977.

LISPECTOR, C. A via crucis do corpo. Rio de Janeiro: Rocco, 1998.

LOPEZ, T. A. et al. Das sombras (entrevista a Hilda Hilst), Cadernos de literatura brasileira (Hilda Hilst), s.1., n.8, 1999, p.25-41

MARIENSKÉ, H. Sexe et vieillesse. Magazine Littéraire, Paris, n.470, p.38-9, 2007.

PÉCORA, A. Nota do organizador. In: HILST, H. Da morte. Odes mínimas. São Paulo: Editora Globo, 2003, p.7-10.

. Nota do organizador. In HILST, H. Cartas de um sedutor. Lisboa: Campo das Letras, 2004, p.7-9.

Nota do organizador. In: HILST, H. Com os meus olhos de cão. 2.ed. São Paulo: Editora Globo, 2006a, p.5-10.

. Nota do organizador. In: HILST, H. Estar sendo. Ter sido. 2.ed. São Paulo: Editora Globo, 2006b, p.7-10.

PICARD, M. Le littérature et la mort. Paris: Presses Universitares de France, 1995.

PIRES, J. A. Grandes espirituais da literatura brasileira. Braga: Publicações da Faculdade de Filosofia - Universidade Católica Portuguesa, 2002.

PRADO, D. A. A Personagem no Teatro. In: PRADO, D. A. et al. A personagem de ficção. São Paulo: Perspectiva, 1987, p.81-101.

RIBEIRO, J. U. A casa dos budas ditosos. 2.ed. Lisboa: Publicações Dom Quixote, 1999.

SÁBATO, E. El escritor y sus fantasmas. Barcelona: Seix Barral, 1979. 


\section{HILDA HILST: \\ "RESPIREI TEU MUNDO MOVEDIÇO"}

Ana Chiara

CALMA, CALMA, também tudo não é assim escuridão e morte. Calma. Não é assim?...

Hilda Hilst. Fluxo Floema, 2003, p.19

O encontro com Hilda Hilst pode ser de recuo assustado, abandono do desafio ou de mergulho no fluxo de uma escrita INAPELÁVEL. Escrita disparada, sob aparente deriva, mas que mantém o foco de atenção à Língua no seu sentido mais rigoroso e material, no difícil jogo de associações livres e de uma metalinguagem crítica e sardônica. Um pé na pura emoção, outro no que Evando Nascimento (2013) chamou de "arte pensante". A controvertida escritora não teme descer aos infernos da experiência do imundo e do inumano, remexer na merda, na escória dos sentimentos, e depois elevar-se ao zênite das emoções translúcidas e sacramentais. Enfrentá-la é ir além de uma experiência estética, como, por exemplo, a da proximidade irrespirável da pulsão clariceana (escritora de maior pudor) ou aquela do encontro extático de uma Adélia Prado; diferente delas, Hilda Hilst torce nosso pescoço até o "corpo da terra", o floema vegetal, a porcaria da putrefação, numa espécie de "roteiro até o silêncio" que sucede o gozo da teatralização da morte do "eu". A morte do eu performada na mesma medida da morte do 
Outro. Estar diante de um corpo morto, como o de Lázaro, reencena vivência da perda subjetiva, vivência do devir cadáver, visão terrífica do outro lado das coisas. Calcinações, resíduos, lixo, torpores vão se desdobrando prismaticamente, como "faces infinitas" e incompletas do INCONTEMPLÁVEL. Essa palavra próxima do nome de Deus, tão próxima na estética de H. H. das palavras adeus, ateu, teu cu.

Segundo Clement Rosset, Gombrowicz diz voltar-se para os baixos valores, mas mente. Ele dota os baixos valores de uma grandeza escandalosa. Da mesma forma Hilda consegue este tipo de contorcionismo do sentido. Trata-se do fato de perceber-se o real com exatidão, mas não negar as consequências dessa percepção, diferentemente do olhar da maioria que, quando se confronta com o mutismo das coisas, com o aleatório, com o efêmero, por negar isso, cria a ilusão, "selon laquelle il y a un secret à forcer, quelque chose à entendre" (Rosset, 1978, p.28).

Nesse sentido, os artistas apaixonados pelo escândalo da vida e de sua contrapartida, a morte, como Hilda - essas sensibilidades pornográficas - criam em torno da existência uma aura de desmedida trágica especialíssima. A indecência, a vergonha e o lixo não dizem somente respeito à temática sexual que inflaciona a escrita de violência, humilhação, dor, gozo e celebração da vida, mas devem ser procurados na própria compreensão do escândalo da vida a ser compartilhado pela literatura e pela arte, dita anestésica, que se inclina ao abjeto como forma provocadora de novas sensibilidades contemporâneas.

A natureza dessa escrita é mesmo a de um enfrentamento com o que a boca não consegue dizer, da inadequação da palavra, da experiência do acontecimento falto. Destes ocos irremediáveis do espírito surgem os melhores momentos de uma escrita entre "o testamento lírico" do pai e as leituras de seus escritores mais amados. Eis o caráter "floema" da literatura hilstiana:

Os sentimentos vastos não têm nome. Perdas, deslumbramentos, catástrofes do espírito, pesadelos da carne, os sentimentos vas- 
tos não têm boca, fundo de sortunez, mundo desvairio, escuros enigmas habitados de vida, mas sem sons, assim eu neste instante diante de teu corpo morto. (Hilst, Rútilos, 2003b, p.85)

Essa literatura representa estados do excesso e da privação nos limites da crise de representação. Ou seja, como ou se a linguagem pode expressar esses estados são as perguntas que aparecem como pano de fundo. Vai e volta obsessivo de uma pergunta sobre a transmissibilidade (compartilhamento) desse tipo experiência e do modo como a língua busca compartilhar a experiência do "trauma". As indagações de Freud e de Benjamin sobre a dificuldade de se transmitirem experiências traumáticas surgem, na escrita de Hilda Hilst, da desorganização da linguagem (sua insuficiência para transmitir o cheiro da morte ou o excesso erótico), suscitando efeitos grotescos das situações extremas. Mesmo o cotidiano ralo das personagens aparece sempre como situação de alarme. As correlações foram roídas, a "natureza carnal", a fisiologia, excreções, fluidos, vulnerabilidade e força, ultrapassam o domínio da representação do real - do realismo em arte - para criar um corporal reinventado. Por outro lado, a própria percepção atua sobre esses estados, de modo a sugerir que a experiência, no momento mesmo em que atua sobre o sujeito, não pode ser percebida nem em sua totalidade, nem de forma contínua: "[..] é inútil querer o real do meu espaço de dentro” (Hilst, 1998). Por conseguinte, ela despreza a representação realista por meio de um deslocamento radical da linguagem. A possibilidade comunicativa, negada de início, a impossibilidade de representar o real do corpo, transformam-se em busca de linguagem, na qual os sentidos estabilizados são transgredidos, violentados e dissolvidos; supera-se a noção de "organismo", segundo Artaud/Deleuze, desarticulando-se os limites binários: dentro/fora, interior/exterior. A escritora contraria, portanto, qualquer noção simplista de realismo em arte, corroendo "por dentro" os próprios pressupostos que fundam essa noção.

Filiada a Sade e a Bataille: a Sade pela noção de transgressão, por estar no além da Língua, do possível da língua, e a Bataille pelo dis- 
pêndio, o gasto sem retorno. Uma economia linguística sem troca: renúncia a trocas. Enfrentando a matéria nos estados extáticos, incomuns, delirantes, provoca com isso a liberação de energia e das perdas exigidas pela arte, por não se inscrever na lógica do capital, do valor de troca, nem do valor de uso, pois é gasto, dom, danação. Bataille aproxima as formas artísticas do conceito de sacrifício: "Or, il este nécessaire de réserver lê nom dépense à ces formes improductives" [...] il signifie, en effet, de la façon la plus précise, création au moyen dela perte. Son sens est donc voisin de celui de sacrifice" (Bataille, 1967, p.30-1). Assim, o artista é visto radicalmente como um ser marginal ao processo econômico da sociedade e também no sentido da própria experiência (do artista). Soberania da linguagem derrotando o logos em favor de um pensamento do excesso e do impossível.

Se Hilda trabalha com a palavra, nela a palavra é distendida ao máximo, transubstanciada, feita carne. Colando o significante no significado, horizontaliza-se. Releia-se o início do texto "Floema". Logo se percebe a afinidade entre a atividade cirúrgica, da qual quero recuperar a etimologia da mão que faz uma intervenção, uma incisão, uma lesão: do grego kheirourgia, de kheír, kheíros (mão) e érgon,ou (obra, trabalho) (Houaiss, 2001, p.730). Precisão cirúrgica da escritora Hilda (que se desdobra em prosa, poesia e teatro), precisão em lidar com seus materiais, precisão atordoante, enganosa, por estratégias de fragmentação, dispersão, comutação de formas, proliferação que atordoam o leitor, com a exposição irônica da matéria corruptível de que somos feitos e de que é feito o mundo:

Koyo, emudeci. Vestíbulo do nada. Até onde está a lacuna. Vê apalpa. A fronte. Chega até o osso. Depois a matéria quente, o vivo. Pega os instrumentos, a faca e abre. Primeiro a primeira, incisão mais funda, depois a segunda, pensa: não me importo, estou cortando o que não conheço. Koyo, o que eu digo é impreciso, não é, não anotes, tudo está para dizer, e se eu digo emudeci, nada do que eu digo estou dizendo. (Hilst, 2003a, p.225) 
Dessa maneira, a transitoriedade da vida revela-se exposta pela força de uma arte que se apresenta como o efeito de uma operação violenta, técnica, precisa, que nos coloca diante daquilo de que a ilusão realista nos priva, age contra o habeas corpus da percepção gasta diante da crueldade do real, desbloqueando os sentidos selvagens que subjazem ao efeito de um olhar despreocupado e obediente. Ao mundo ordenado, orgânico, ilusório da representação realista, opõe uma dimensão crua e incômoda do real. Arte da dissolução e do desapego ao eu, na contracorrente do narcisismo contemporâneo, mergulha no anonimato, nas baixas conformações sem psicologia, sem caráter, criando embriões de personagens, fetos como curiosidades museológicas, crime contra a natureza, império do artifício, corrompe e ilumina os sentidos calcificados. Arte da truculência e destruição, da virgindade e da limpidez do ato. Jorro inestancável de palavras como lava vulcânica, uma arte em disparada, projétil disparado entre os dois olhos do público que sucumbe ao incômodo da crueldade desse amor à língua. Desse manejo da língua que desperta neles a consciência de sua própria crueldade, truculência, como um princípio de júbilo e submissão diante da soberania da arte.

O leitor de Fluxo-floema, livro publicado em 1970, deve percorrer os desmoronamentos de uma linguagem tortuosa, enigmática, por vezes irônica, que, ao contrário das narrativas tradicionais, não cria nem desenvolve peripécias, nem conflitos, nem contornos psicológicos para personagens. Hilda também não ancora a narrativa numa personagem monológica. Anatol Rosenfeld chama atenção para a estrutura tripartite dos textos de Fluxo-floema, em suas oscilações por zonas de luz e sombra, de simbólica solar/ lunar: "Em cada um dos textos há três 'personagens', melhor três máscaras que se destacam” (Rosenfeld, 1970, p.10). A escrita dramatiza-se, perpassa as vozes da narrativa, confunde e funde essas vozes. Não se trata, como aponta Alcir Pécora na bela apresentação do livro, de um fluxo de consciência nos moldes joyceanos, nem de Virgínia Woolf, ou seja, dos modelos das estratégias discursivas do alto modernismo do século XX, pois não se investiga uma possível interio- 
ridade desalinhada, nem tampouco concorre com o jogo surrealista da escrita automática. Como esclarece Pécora (2003):

Não se trata, contudo, de um "fluxo de consciência" usual, [...] o que dispõe como pensamentos do narrador não são discursos encaminhados como uma consciência solitária supostamente em ato ou em formação, mas como fragmentos descaradamente textuais, disseminados alternadamente entre diferentes personagens que irrompem, proliferam e disputam lugares incertos, instáveis, na cadeia discursiva. (p.10)

Portanto, o controle que Hilda exerce sobre a linguagem vem de sua vocação de dramaturga apontada pelo crítico. Esse trabalho de armação teatral que poderia ser aproximado do que Gilles Deleuze chama de método da dramatização.

Quando se procura corresponder um tal sistema de determinações espaço-temporais a um conceito, parece-me que um logos é substituído por um "drama", parece-me que se estabelece o drama desse logos. O senhor diz, por exemplo, dramatiza-se em família. É verdade que a vida cotidiana está repleta de dramatizações. Alguns psicanalistas empregavam essa palavra, creio, para designar o movimento pelo qual o pensamento lógico se dissolve em puras determinações espaço-temporais, como no adormecimento. [...] Seja um caso de neurose obsessiva, no qual o sujeito não para de retalhar [...] Trata-se efetivamente de um drama, dado que o doente ao mesmo tempo organiza um espaço, agita um espaço e exprime nesse espaço uma Ideia do inconsciente. Uma cólera é uma dramatização que põe em cena sujeitos larvares. (Deleuze, 2006, p.145-6)

Pécora, como responsável pela reedição da obra de Hilda pela editora Globo, costumava reclamar uma leitura mais abrangente da obra de Hilst. No entanto, a própria escritora tinha consciência de uma neurose obsessiva que a mantinha presa a certos temas e 
recursos de uma "literatura essencial", segundo declara em entrevista aos Cadernos de literatura do IMS. Ou seja, Hilda Hilst não se interessa em contar uma história, em representar os conteúdos do mundo, nem das camadas da consciência ou do inconsciente. Hilda perquire, circunscreve (escreve em círculos), busca de modo dramático - pondo vozes em diálogo - a melhor maneira de dirigir uma pergunta à Língua, modos de colocar as perguntas sobre a experiência, o vivido, a existência, sem deixar que as respostas se anteponham à visão do múltiplo, do fragmentário, do singular do tempo diferido. A instabilidade das vozes, a impossibilidade de dar contornos fechados às respostas, a precariedade das visões parciais compõem esse jogo reflexivo que se espraia horizontalmente, sucessivamente e sem segurança nenhuma sobre um vazio impossível de ser preenchido definitiva e totalmente:

Isso quer dizer que a minha pergunta no tempo é igual à mosca que tomba? E o de antes é nada? Perco meu faro, não sei mais do meu ninho, penso que devo lançar ao charco a bússola de sempre, às vezes aponta para o pé, digo sei é na unha de Haydun que construo meu passo, depois aponta para o alto, digo não sei, não posso ir até a fronte, $[\ldots]$ ainda penso que um NADANADA de mim, um MUITOPOUCO te percorra, e entendas esse que se amolda dentro do meu corpo, este protonauta vivo, vermelho. (Hilst, 2003a, p.243-4)

Para este estudo, o conto "Lázaro" funciona como uma peça deste puzzle hilstiano, na vertente complicada de suas parábolas, suas alegorias. Mario Perniola, ao estudar o pensamento de Luigi Pareyson (1918-1991), percebe nele uma impossibilidade de dizer o real tão anunciada na literatura hilstiana: "A característica da realidade é a sua inconceitualidade, o seu ser absolutamente independente do pensamento" (Perniola, 2010, p.182). Essa dificuldade impõe à linguagem uma aproximação do fato por apropriações alegóricas. Decorre dessa floresta cerrada que se torna o real, a nosso ver, o caráter de apropriação profanadora do discurso religioso perpetrada pela escritora. 
Nessa perquirição do "inexaurível”, o idioma de Hilda Hilst não é fácil. Desliza por quatro gêneros: o masculino, o feminino, o neutro e o coletivo, por desarticulações de palavras, por aglutinações sonoras, obedecendo a um ritmo próprio. A Língua move-se entre lugares de descanso impossível. A interlíngua do interdito, do entredentes, do entreouvido. A língua de Fluxo-floema balbucia com filetes de sangue coagulados, fala como se fosse água parada, sovertendo-se, redemoinho, boca banguela, comendo a si mesma, como uma das personagens:

[...] um outro feito de mim, mas todo nu, despojado de tudo, nu no corpo, nu por dentro, ah, vai balbuciar, isso vai, não abro mão do balbucio, vai dizer blu, plinka, plinka, oheohahu, vai entrar dentro do rio e gritar OHEOHUOHAHU. (Hilst, 2003a, p.68)

A língua é presa num filete rosado de matéria, é áspera, pesa na minha boca, tudo pesa, a maior parte do dia fica à procura de migalhas, depois se distende procurando a palavra. PESA. (Ibid., p.234)

Em Fluxo-floema, este estranho livro, Hilda Hilst exaspera essa orientação em direção ao abstrato alegórico. O caráter religioso num sentido mais amplo, aquele de uma busca inexaurível de um sentido para a "vida dura" - vigora absoluto e as mutações imperam. O corpo humano em seus devires, em suas metamorfoses em animais estranhos, corpos em decomposição como o de Lázaro, quadro repulsivo e fascinante ao mesmo tempo, um quadro lúgubre de desolação, um memento mori. Hilda torna-se uma pergunta: quem fala por mim agora? Por quem este tipo de arte fala? - forçando limites, a transcendência da própria condição faz reinar a dispersão no Todo.

A gruta em que a personagem de Lázaro é enterrada se tornará o lugar oco sem salvação; gruta, caverna, buraco negro da perda da 'in-di-vi-du-a-li-da-de', transcendência em formas arcaicas, larvares, como o cadáver envolto em perfumes. Matéria dolorosa, matéria de dor e de superação da dor, fragilidade e força, derrelição. 
Como os grandes espectros, Lázaro está encarcerado na morte e, ao mesmo tempo, liberto da contingência: potência e impotência da matéria. Artista da profanação dos sentidos dogmáticos, Hilda revela inclinação para uma especial concepção religiosa do cosmos; sentimento místico, mítico, contudo, aberto ao vazio, ao abandono dos deuses; deslocando o caráter totalitário da veneração do sagrado para o campo da experimentação da matéria abjeta, contagiosa, deslocada e suja. Hilda força os limites da busca, anseia pela transcendência da própria condição, pelo uso disseminador dos mitos.

Religio não é o que une homens e deuses, mas aquilo que cuida para que se mantenham distintos. Por isso à religião não se opõem a incredulidade e a indiferença com relação ao divino, mas a "negligência", uma atitude livre e "distraída" - ou seja, desvinculada da religio das normas - diante das coisas e de seu uso, diante das formas da separação e seu significado. Profanar significa abrir a possibilidade de uma forma especial de negligência, que ignora a separação, ou melhor, faz dela um uso particular. (Agamben, 2007, p.66)

No conto Lázaro, experiência profanadora das escrituras sagradas, seremos obrigados a ver do escuro de uma cova aquilo que um morto "vê" "do dentro do corpo": "Vejo-a de cima, dos lados, de frente, vejo de um jeito que nunca vi. Jeito de ver de um morto" (Hilst, 2003a, p.113). Somos também bafejados pelo sopro vital que se esvai no último suspiro: "Tento dizer, mas uma bola quente vem subindo pela garganta, agora está na minha boca” (Hilst, 2003a, p.112). Somos espectadores de um encontro entre o Lázaro morto e o Outro de si, Rouah, seu corpo estranho, seu outramento num ser "ab-jeto". O nome do ser com o qual Lázaro se confronta num diálogo pós-morte é ROUAH. Em hebraico Ruah, em grego Pneuma, em latim Spiritus, de onde temos a palavra "espírito" em português. O nome indica sopro vital, pneuma. Ruah não se pode traduzir em uma só palavra, pode ser sopro de vida, vento, o movimento do ar, hálito, o espírito. Nas escrituras hebraicas, ruah elohim é 
o vento criativo de Deus. No conto de Hilst, é um ser sarcástico e sexuado, duplo de Lázaro, um espírito encarnado, a parte relegada aos "escuros do corpo" que se libera para Lázaro vê-la, para contemplar-se.

Lázaro metamorfoseado num corpo larval, embalsamado pelos melhores perfumes de Marta, assim como os leitores podem se sentir, deixa suas carapaças defensivas, livrando-se das identificações sociais: "Meu corpo enfaixado..." é a frase que abre esse conto em primeira pessoa, no qual a experiência incomunicável do corpo é configurada no corpo morto, como uma descida aos infernos, uma vivência do enterrado vivo, espanto, perda de controle, loucura. Lugar do indecidível derridiano, khôra, na literatura hilstiana, procede da capacidade de estar fora da lógica inclusão/exclusão, verdade/mentira, pensamento/sensibilidade como aporias das apresentadas pela arte da escritora. Relembrem-se as palavras de apresentação do conceito no livro Khôra, de Jacques Derrida:

A Khôra não é nem "sensível", nem "inteligível”; ela pertence a um "terceiro gênero" (triton genos, 48e, 52a). Sobre ela não se pode nem mesmo dizer que ela não é nem isto, nem aquilo. Não basta lembrar que ela não nomeia nem isto, nem aquilo, outras simultaneamente isso e aquilo. Mas essa alternativa entre a lógica de exclusão e aquela de participação [...] talvez se deva a uma aparência provisória e às coerções da retórica, ou até mesmo, a uma inaptidão em nomear. A Khôra parece estrangeira à ordem do paradigma. Esse modelo inteligível e imutável. (Derrida, 1995, p.10)

Pertencente, portanto a um "logos bastardo" (Derrida), receptáculo (mãe, ama, molde), a vivência de Lázaro na gruta, no "buraco fundo", é a do autoparimento. "Lázaro" dispõe as forças vitais num quadro animado onde se debatem a vida e a morte, o amor e o nojo, o mendigo e o amigo querido de Cristo, o incriado e a criação; como se, além do "fluxo" dialógico que a move sempre em direção ao Outro, a literatura de Hilda Hilst buscasse também a seiva - floema, o alimento ancestral, mas sempre político e situado, que propi- 
cia ao homem a criação de um mundo renovado, recriado, por isso "Meu peito se alarga, minha boca disforme suga uma seiva que não vê" (Hilst, 2003a, p.119). Ressuscitar dos mortos como necessidade vital (encontro com seu pneuma, com sua respiração), no cavo fundo aonde só um morto poderá ir, é o movimento impensável narrado por Lázaro, "enquanto se morre", cumprindo a narrativa do irrespirável: "na morte seria preciso encontrar palavras exatas" (Hilst, 2003a, p.113). Hilda ensaia uma narrativa do impossível. Morrer é encontrar-se, defrontar-se com seu próprio corpo como Outro/alteridade. Paralelo ao que a própria Hilda, em suas experiências de gravação de "vozes", propõe como o desejo profundo de sua literatura: "Então, é isso que na literatura eu também proponho: fotografar a pessoa de todos os lados e, principalmente, a essencialidade dela. Quer dizer que ela reconheça a cara densa, escura, mais profunda e mais terrível dela mesma e ela aprenda a conviver com essa cara" (Diniz, 2013, p.72).

Desse encontro tenebroso, Lázaro, penetrado por uma "embriaguez da vontade", assiste ao mundo sem estar nele, alcançando uma suprema sabedoria sobre o amor fraterno. Não o conhecimento pelo intelecto, mas a vivência apaixonada, da transformação pelo amor. No entanto, advertimos que não se trata de uma pregação religiosa de sentido confessional ou de autoajuda. A própria Hilda renega o imediatismo deste "agarrar depressa demais o sentido": "Eu não pratico nenhuma religião” (Diniz, 2013, p.72). ${ }^{1} \mathrm{E}$, se há algum sentido religioso nesse empreendimento artístico, seria antes o de superar o egoísmo do próprio corpo, do nome, da individualidade, para poder pensar/agir no outro. Na obra de Hilda, portanto, o corpo exerce a função primordial de condutor de um conhecimento, de uma espécie de revelação, de alcance de um saber intuído, lux in tenebris:

Mas foi na escuridão, e como escuridão, que o corpo foi concebido. Ele foi concebido e moldado dentro da caverna de Platão,

1 Conferir o apego de Hilda Hilst ao livro O Cristo recrucificado, de Nikos Kazantzakis (1986-1957). 
como a caverna: prisão ou tumba da alma. A encarnação faz penetrar o princípio daquilo que a obscurece e que a ofusca. O corpo é todo, a princípio, concebido na angústia desta asfixia. $\mathrm{O}$ corpo-caverna é o espaço do corpo se vendo de dentro, vendo de dentro (e sem nascer) o ventre da mãe, ou se vendo ele mesmo como sua própria matriz, sem pai nem mãe, pura escuridão de autofiliação. Assim, o olho noturno da caverna se vê, e se vê noturno, ele se vê privado do dia. O corpo é o objeto da sombra - e seu olhar tenebroso é já, por isso, a impressão, o resto de luz, o rastro (signe: rastro, signo, sinal) da visão solar. Lux in tenebris, o corpo da encarnação é o signo, absolutamente. (Nancy, 2006, p.60)

Do corpo sarcófago/útero de Lázaro, Rouah extrai o cálice (amoroso) de carne. "Corpo do meu corpo." Lázaro transmuda-se num corpo-amoroso, e somente do lugar fundo e abjeto do amor-ágape ele poderá compreender o amor humano, muito mais que humano de Judas: "Eu acho que o amor do Iscariote tem de ser assim como é” (Hilst, 2003a, p.128). Ao mesmo tempo, porém, será por uma recusa a ser como Judas que Lázaro afirmará sua capacidade de, digamos, "livre-arbítrio", superação de si e religação com o restante dos homens. Nesse sentido, o conto, quando se inscreve como imitação da vida e paixão de Cristo, pelo episódio figural da morte e ressureição de Lázaro, também apontará para a experiência dos corpos encapuzados e torturados dos regimes de repressão sob o qual se vivia à época em que Hilda o escrevia, de onde se extrai a atualização da desmedida violenta da segunda morte de Lázaro - quando, aprisionado, encapuzado e jogado no mar, chega a um mosteiro (sem precisão de local ou data) no qual Cristo já se tornou um nome vazio, uma "foto na parede".

Talvez se possa aproximar Hilda Hilst do conceito de sindérese, de busca da revelação consciente, que vem de Tomás de Aquino: "capacidade espiritual, inata, espontânea e imediata para apreensão dos primeiros princípios da ética, capaz de oferecer intuitivamente uma orientação para o comportamento moral" (Houaiss, 2000, p.2577). Na vertente warburgiana do pensamento por imagens, a 
sindérese tornaria possível "un formulário etico-allegorico che tende a far luce sulle realazioni del mondo interiore con le forme del cosmo visible, spaziale" (Bianchi apud Via, p.130) de caráter irônico, profano.

A sindérese envolve, portanto, uma consciência ética; em Hilda, essa consciência passa pelo corpo, como o caso de amor crístico, a paixão do corpo como materialização da doação, da entrega amorosa. Lázaro crê, com paixão, nesse amor fraternal que Cristo representaria na terra até se defrontar com o vazio deixado, como o monge, entre carinhoso e debochado, revela: "Deus, Lázaro, Deus é agora a grande massa informe, a grande massa movediça, sem lucidez. Dorme bem, filhinho" (Hilst, 2003a, p.140-1). As "parábolas" de Hilda funcionam nessa via para atingir uma revelação do que ela chama de "essencialidade" (eu pergunto: a seiva, o floema?) perdida sem remissão, dissolvida no informe, no movediço. Sem fervor místico que repetiria (como nas imitações extáticas da vida de Cristo) as verdades da religião. Essa aproximação se dissolverá pelo próprio gasto do tempo. Hilda, como Kafka, pisa no terreno movediço que se tornou a tradição.

Eliane Robert Moraes, no belo artigo "Da medida estilhaçada", estuda o bestiário de Hilda Hilst, do qual destaca a figura do Deus- porco como expressão desalentada de uma pergunta sem resposta: "Pergunta sem resposta, o animal ostenta esse corpo às avessas que obedece apenas ao regime intensivo da matéria, deixando a descoberto as marcas imponderáveis do tempo. Diante dele, as investidas racionais do cogito ficam reduzidas à duvidosa autoridade de um 'Porcus Corpus'” (Moraes, 1999, p.122). Anteriormente, por uma apreciação dos jogos verbais da escritora, Robert Moraes demonstrara o modo de aproximação entre as ideia do porco e do corpo, de fundamental importância, a meu ver, para a compreensão da obra de Hilst. A crítica afirma:

Assim como dog e god estão unidos pelos secretos elos da língua, também a diferença entre o homem e o animal depende apenas de uma sutil inversão: "Porque cada um de nós, Clódia, tem de achar 
seu próprio porco. (Atenção, não confundir com corpo). Porco, gente, porco, corpo às avessas". (Moraes, 1999, p.121)

Sem dúvida, a escritora, como sabemos, é apaixonada pela figura da porca, como declarou em entrevista: "Vocês viram, eu tenho ali um retrato de uma moça beijando uma porca; eu adoro porcos" (Cadernos, 1999, p.34). Também a porca, não esqueçamos, é o alterrego da narradora de $A$ obscena senhora $D$.

No caso da inclinação imagética pela figura do(a) porco(a), no lugar do movimento ascensional dos olhos, como nas representações das santas católicas, Hilst prefere aproximar o focinho da porca (do corpo) da lama e, na lama, chafurdar em busca de algo "do dentro": "Eu estou dentro do que vê. Estou dentro de alguma coisa que faz a ação de ver" (Hilst, 2003a, p.147). Esse deslocamento do olho para o focinho aproxima-se do que Walter Benjamin detecta do ouvido, em Kafka, numa carta no trecho que reproduzo e na qual comenta a relação transgressiva da literatura de Kafka com as escrituras hebraicas:

Kafka escutava o que lhe dizia a tradição e quem ouve intensamente não vê. Este ato de ouvir é cansativo, sobretudo porque só coisas confusas chegam até aquele que ouve. Não há doutrina a se aprender e nem conhecimentos a conservar. O que se capta de repente são coisas que não estão determinadas para nenhum ouvido em especial. Isto inclui um estado de coisas que caracteriza estritamente a obra de Kafka por seu lado negativo (quase sempre sua característica negativa será mais rica de perspectiva que a positiva). A obra de Kafka representa um adoecimento da tradição. Tratou-se de definir a sabedoria como o lado épico da verdade. Assim, a sabedoria é caracterizada como um bem da tradição. [...] $\mathrm{O}$ verdadeiramente genial em Kafka foi que ele experimentou algo totalmente novo: ele abriu mão da verdade, a fim de ater-se à transmissibilidade, ao elemento "hagadístico". A literatura de Kafka é originalmente de parábolas. Mas sua beleza e desgraça é ser mais que parábolas. Ela não se coloca aos pés da doutrina, assim como a 
Hagadá o faz em relação à Halahá. E quando se submete, de repente levanta uma poderosa garra contra ela. (Benjamin, 1993, p.304)

Essa apropriação das "escrituras sagradas" em amplo sentido é um procedimento usual na literatura de Hilda Hilst. A escritora penetra nesse "mundo movediço" de uma escuta. Isso se verifica tanto na apropriação da tradição da religião, no sentido estrito das escrituras, da qual o conto Lázaro é um exemplo, como também no amplo sentido das "escrituras leigas" da literatura canônica vejam-se os modelos homenageados por ela e citados na trilogia pornográfica, apontados por tantos estudos críticos. E, não bastando esses cruzamentos de intertextualidade, verifica-se também no modo como é capaz de citar o popular, a língua do povo, o que é considerado pornografia popular, linguagem de "baixo calão". Ao incorporar ao seu fluxo de pensamento/ escrita o que corre subterraneamente nos veios da tradição, ao manter sob o controle de um focinho a lama e a flor, a escritora cria esse fundo movediço onde as certezas perdem estabilidade, onde a própria "ambiguidade é ambígua", como "poderosa garra" que se levanta contra a verdade, num chão minado, onde nada pode, ao final, nos curar, nos redimir ou nos salvar. Saídos do conto, como expulsos do ventre úmido, da khôra em que imprimimos nossa imagem, nós, os leitores sem Deus, sem pai, nem mãe, nós, nesta literatura, olhamos o olho vazado de nossa fratura, de nossa perdição.

\section{Referências bibliográficas}

AGAMBEN, G. Profanações. Tradução e apresentação Selvino José Assmann. São Paulo: Boitempo, 2007.

BATAILLE, G. Visions of Excess. Minneapolis: University of Minnesota press, 1985. . La Part maudite. Paris: Minuit, 1967.

BENJAMIN, W; SCHOLEM, G. Correspondência. Trad. Neusa Soliz. São Paulo: Perspectiva, 1993. 
BIANCHI, L. Warburg, Cassirer et Bruno. Quelques remarques sur "individu et cosmos". In: VIA, C. C. Introduzione a Aby Warburg. Laterza: Itália, 2011.

CADERNOS de Literatura Brasileira - Hilda Hilst. Rio de Janeiro: Instituto Moreira Sales, n.8, out 1999.

DELEUZE, G. A ilha deserta e outros textos. Textos e entrevistas (19531974). Organização de Davi Lapoujade; revisão técnica Luiz B. L. Orlandi. São Paulo: Iluminuras, 2006.

DERRIDA, J. Khôra. Trad. Nícia Adan Bonatti. Campinas, São Paulo: Papirus, 1995.

DINIZ, C. (Org.). Fico besta quando me entendem: entrevistas com Hilda Hilst. São Paulo: Globo, 2013.

HOUAISS, A. Dicionário HOUAIS da Lingua Portuguesa. Rio de Janeiro: Objetiva, 2001.

HILST, H. Fluxo-floema. São Paulo: Globo, 2003a. Rútilos. São Paulo: Globo, 2003b.

MORAES, E. R. Da medida estilhaçada. In: Cadernos de Literatura Brasileira - Hilda Hilst. São Paulo: Instituto Moreira Sales, n. 8, out. 1999, p.114-26.

NASCIMENTO, E. Artes pensantes e incomparáveis. Celuma n.3, dez. 2013. Disponível em: <http://www.mariantonia. prceu.usp.br/celeuma/?q=revista/3/dossie/artes-pensantes-eincompar\%C3\%A1veis>. Acesso em: 14 fev. 2014.

NANCY, J-L. Le Corpus. Paris: Métaillé, 2006.

PÉCORA, A. Nota do organizador. In: HILST, H. Fluxo-floema. São Paulo: Globo, 2003, p.9-13.

PERNIOLA, M. Desgostos: novas tendências estéticas. Trad. Davi Pessoa Carneiro. Florianópolis: Editora da UFSC, 2010.

ROSENFELD, A. Hilda Hilst: poeta, narradora, dramaturga. In: HILST, H. Fluxo-floema. São Paulo: Perspectiva, 1970, p.10-7.

ROSSET, C. Le Réel. Traité de l'idiotie. Paris: Ed. Minuit, 1978. 


\section{AQuelas COISAS E UM POUCO MAIS: A ERÓTICA SENIL ${ }^{1}$}

Eliane Robert Moraes

Talvez nenhum outro texto de Hilda Hilst seja tão ousado quanto o "fragmento pornogeriátrico rural", que ganha nome de suas personagens femininas, ao que tudo indica inspiradas nas irmãs Brontë: a Isabel de $O$ morro dos ventos uivantes e a Bertha Mason, de Jane Eyre. Porém, na contramão do puritanismo vitoriano com o qual as notáveis autoras oitocentistas foram obrigadas a conviver, o insólito diálogo hilstiano se impõe pela absoluta falta de pudor com que introduz seus protagonistas, cujas idades avançadas não impedem a prática das mais atrevidas atividades lúbricas. É o que se lê já desde o início de "Berta - Isabô":

Isabô: Ai, Berta, tô mar... tive uns presságio... Vi uma véia tão véia coçando oiti na esquina.

Berta: Iiii, Isabô, essas coisa de coçá o oiti se chama prurido senir... daqui pra poco nóis tá iguarzinha. Te lembra do tio Ledisberto? Mandava a Eufrosina ficá fazendo cafuné nos cabinho do cu dele.

Isabô: Credo, Vige Maria, Berta! Meu tio, hein,... imagine... gente de bem. Tu é que coçava os bago dos menininho e tirava os ranho

1 Este texto, em versão reduzida, foi publicado originalmente, sob o título de "O sexo dos velhos”, em Rizzo, R.; Weintraub, F.; Bosi, V. et al. (Orgs.). Revista Jandira. Juiz de Fora: Funalfa, 2004, v.1, p.96-9. 
dos buraco do nariz e enfiava na boca da Dita, coitadinha, aquela neguinha fedida que era tua prima.

Berta: Iii, Isabô, tu tá tão porca que tá parecendo aquela véinha curta da Hirda, como é que é mesmo?, a Hirste?

Isabô: Iii, essa véia é safada. Porca, porca, mesmo curta. Imagine só que gente que mora neste país. (Hilst, 2014, p.239)

Não poupando nem a si mesma, a escritora faz tabula rasa dos discursos mais díspares, aproximando a alta literatura das romancistas inglesas da fala roceira que caracteriza boa parte da cultura do interior paulista, sem falar da profusão de obscenidades populares. Se tais aproximações são recorrentes na prosa de Hilda Hilst, aqui elas ganham um colorido particular já que, como observa Alcir Pécora, o dialeto caipira e a expressão escatológica têm por objetivo "a provocação e o gosto perverso de rir às custas da falsidade matuta, exposta da maneira mais crua” (Pécora, 2004, p.95). Mas, até o riso, nesse estranho e desbocado fragmento, não se esgota em si mesmo.

Convenhamos: nada mais difícil do que admitir uma erótica senil. Aos velhos normalmente se atribui uma castidade absoluta, só comparável ao "sexo dos anjos", ou, na via oposta, uma incontestável inclinação à perversidade. Daí o costume, pelo menos no Brasil, de se chamar de "safado" o velho que demonstra qualquer interesse sexual, por menor que seja. Empurrado para esses polos extremos, o erotismo dos idosos fica condenado ao silêncio, até mesmo em tempos que se gabam de uma suposta "liberalidade sexual". Nada mais difícil, portanto, do que imaginar uma erótica senil.

É a essa tarefa que se dedica o diálogo de Hilda Hilst, valendo-se de uma via expressiva muito cara à autora: o escracho. Berta e Isabô são senhoras de idade avançada que, em vez de devotar as tardes ao crochê e as noites às novelas, parecem preferir passatempos menos castos. Se, como todo idoso, elas gostam de recordar o passado, as lembranças que lhes vêm à mente são invariavelmente marcadas por um tom licencioso, seja na evocação de um tio que gostava de "cafuné nos cabinho do cu dele", seja na de um antigo namora- 
do: "quando ele metia eu via tudo roxo, lilás, bordô". Valem para ambas, portanto, as palavras categóricas de Berta acerca de Isabô: "Tu só pensa nas partes de baixo".

A volúpia das velhinhas não se esgota, porém, em lembranças e pensamentos. Em meio ao diálogo das duas amigas, surge a figura de "Seo Quietinho" - por certo uma referência à expressão popular "come quieto", o que não deixa de ironizar a silenciosa sexualidade da velhice - que lhes propõe uma passagem do discurso à ação.

Berta: Quem é, meu deus? (Olha pela janela) Ai, Vige Maria, é o Quietinho, tá loco pra fazê aquelas coisa com a gente.

Isabô: Que coisa tu qué dizê, hein?

Berta: Aquilo que tu fazia com o Tonho.

Isabô: Mardita! Num faço isso há mais de trinta ano. (Hilst, 2014, p.239)

Ao convite do ancião, ambas respondem com desembaraço e, embora Berta confesse sua falta de prática, é ela mesma quem decide saciar a lascívia do amante senil: "Ah..., eu quero. Óia como eu tô arripiada”. Dessa forma, o que Hilda Hilst coloca em cena é um erotismo prosaico e susceptível à passagem do tempo, que vem desmentir tanto o ideal do bom velhinho casto quanto a figura do idoso perverso que representa uma ameaça aos valores da família e da sociedade. Aliás, como sugere o texto, se o sexo permanece na velhice, também ele envelhece, e isso acontece em paralelo ao resto do corpo, sobretudo àquelas partes mais voltadas aos prazeres da sensualidade. A boca, por exemplo.

A boca por certo envelhece. Prova disso está nos dentes. Conscientes da ação do tempo sobre eles, Berta e Isabô rezam para a santa Apolônia - "que protege os dentes" -, evocando um tema recorrente em Hilda Hilst. Frequente na obra da autora, o motivo dentário traduz quase sempre uma dimensão trágica da existência humana: se, de um lado, os dentes representam a única possibilidade de eternizar a matéria, de outro, viver significa necessariamente deixá-los apodrecer. 
"Dentes guardados. Não acabam nunca se guardados. Na boca apodrecem." - recorda o protagonista de Com os meus olhos de Cão, antecipando a pergunta que conclui uma crônica de Cascos $\mathcal{E} \mathrm{Ca}$ rícias: "por que os dentes caem quando estamos velhos, mas ainda vivos, e permanecem eternos nas nossas límpidas e luzidias caveiras?" (Hilst, 1998, p.14). Semelhante questão aparece em Estar sendo. Ter sido, que põe em cena um personagem às voltas com seus problemas dentários: na iminência de ficar desdentado, o decrépito Vittorio vê-se impedido de acalentar até mesmo a derradeira esperança de permanecer através dos dentes. Condenado a não deixar nem esse último traço de seu corpo depois de morto, seu confronto com o nada ganha uma gravidade insuspeita.

Não é essa gravidade ontológica, contudo, que provoca a incursão de Berta e Isabô ao motivo dentário. Muito pelo contrário: colocadas diante da evidência de estarem desdentadas, as velhinhas parecem ignorar por completo as angústias que assombram o velho Vittorio, operando uma formidável reversão nessa circunstância. Ora, o fato de não terem dentes vai concorrer aqui inteiramente a seu favor, ou melhor, a favor da lubricidade que lhes é incitada pelo amigo:

Seo Quietinho: Mas eu vim aqui pra isso mesmo, pois vocês num têm dente... é pra chupá mió.

Berta: Aiiiiii, num fala assim nas porta da rua!

Isabô: Abre logo, que a vila intera vai sabê dessas luxúria. (Hilst, 2014, p.240)

Nessa reviravolta insinua-se uma afinidade intensa entre a boca e o sexo, que não deixa de lembrar certas formulações de Georges Bataille, não por acaso um escritor lido e citado por Hilda Hilst. Em um artigo intitulado "Les deux visages", o autor afirma que "nos diversos jogos de amor os seres humanos provam que têm dois rostos". Tendo em vista que a correspondência essencial entre ambos seria dada pela boca e pelo ânus - aos quais se associam respectivamente os outros órgãos faciais e genitais -, ao primeiro ele 
dá o nome de "rosto oral" e, ao segundo, de "rosto sacral" (Bataille, 1976, p.527-8).

Com tais considerações em mente, não é difícil constatar que a correspondência entre os dois órgãos ganha uma nova feição no caso dos velhos, uma vez que o rosto, pelo menos em sua versão "oral", é justamente aquela parte do corpo humano que mais denuncia a idade. Nesse sentido, o paralelo entre ambos os rostos vem confirmar a singularidade da erótica senil, já que o sexo, em vez de desaparecer na velhice, se mantém vivo - mas tornando-se, ele também, velho.

Assim, se as peripécias sexuais de Berta, Isabô e "Seo Quietinho" podem perturbar as concepções correntes do erotismo, isso não se deve simplesmente ao fato de serem três velhinhos praticando o sexo, mas sobretudo à evidência de que há um sexo exclusivo dos velhos. Evidência que coloca em cena um imaginário bem distinto daquele prometido pelas miríades de corpos jovens, sarados e saudáveis que, dia após dia, exibem seu previsível erotismo nas telas da televisão. Evidência por certo escandalosa que, como outros escritos de Hilda Hilst, vem contestar as imagens idealizadas da sexualidade que povoam tanto os tradicionais discursos de defesa da moralidade quanto os modernos catecismos do consumo.

\section{Referências bibliográficas}

BATAILLE, G. Le deux visages. In: La phénoménologie érotique. (Oeuvres Complètes, t.VIII). Paris: Gallimard, 1976.

HILST, H. Cascos E Carícias - Crônicas reunidas. São Paulo: Nankin Editorial, 1998.

Berta \& Isabô - Um fragmento pornogeriátrico rural. In: Pornô chic. São Paulo: Globo, 2014.

PÉCORA, A. As irmãs Brontë. In: Jandira 1 - Revista de Literatura. Juiz de Fora: Funalta Edições, 2004. 


\section{Sexualidade e Riso: a tRILOgIa OBSCENA de HILdA HILST}

Mechthild Blumberg

\section{Literatura erótica de autoras brasileiras}

The use of an erotic theme is one way to alter women's subjectification. It is a release from stereotypes, a vehicle for establishing a separate identity. [...] The erotic novel usually examines the ideology of power [...] As such, feminine eroticism is a tool for the examination of the feminine condition from a feminine perspective [...] The use of the erotic in contemporary Brazilian women's letters indicates a shift from a self-censoring, internalized and often negative self-image toward reintegration into a wider society. [...] Erotic literature is currently one of the chief sellers in the Brazilian market. [...] eroticism can be viewed as a conscious manipulation of the author/narrator/reader relationship in an attempt to restructure values.

(Quinlan, 1991, p.110)

A liberação sexual feminina foi um dos grandes temas da literatura de mulheres, que explodiu, no âmbito do segundo movimento feminista, na segunda metade do século XX. Também no Brasil 
surgiu um grande número de textos escritos por mulheres, tematizando a liberação feminina de relações familiares e conjugais sentidas como opressoras, a favor de uma vivência sexual livre e ativa, e, em parte, novamente alienante na impessoalidade de aventuras sem compromisso e experimentações meramente corpóreas.

O tema do amor absoluto - elaborado, por exemplo, em Cecília Meireles - é substituído pelo erotismo como dinâmica da procura de uma nova identidade feminina. Ele toma aspectos que vão da liberdade sexual à pornografía e ao obsceno, sendo relacionado por algumas autoras com um sentimento religioso de variados matizes, através do qual o erotismo funciona como elemento integrador das dimensões terrena e divina.

Em A casa da paixão (1972), Nélida Piñon tematiza a liberação do corpo das normas disciplinadoras da civilização cristã e burquesa. É a redescoberta e a exaltação da natureza, do caos original, telúrico, elementar, instintivo e erótico, a autodescoberta feminina através da sexualidade.

Nos anos 1980, chamaram a atenção com um discurso erótico autoras como Marina Colasanti (E por falar em amor, 1984) e Márcia Denser (com a compilação de textos próprios e de várias autoras - Edla van Steen, Rachel Jardim, Lygia Fagundes Telles, Nélida Piñon, Cecilia Prado, Olga Savary, Sônia Coutinho, Renata Pallotini, Myriam Campello, Cristina de Queiroz, Sonia Nolasco Ferreira - em Muito prazer, 1980 e O prazer é todo meu, 1984). Os textos de, por exemplo, Denser, Coutinho e Pallotini se caraterizam por uma linguagem provocadora que descreve com ironia a troca de papéis e de parceiros. A conquista definitiva da consciência corporal em nível literário leva à oscilação entre o êxtase provocado pelo corpo, liberto até à beira da loucura, e a vivissecção implacável da condição de objeto ao qual a própria mulher se reduziu na liberação sexual. O herético frenesi sexual como tentativa de união com o divino insere uma autora como Denser na tradição sacrílega de Henry Miller, uma tradição à qual Hilda Hilst irá se referir. Na poesia de Yêda Schmaltz (A alquimia dos nós, 1979, Bacos e Anas brasileiras, 1985), o erotismo vai da sensualidade dramática ao lúdico e é im- 
pregnado de sacralidade tanto como de feminilidade instintiva e orgiástica. A fusão do erótico com o divino também é trabalhada por Adélia Prado (a partir de 1976), na combinação de sensualidade e espiritualidade, lirismo e desbocamento, e é, como veremos a seguir, um dos eixos em redor dos quais gira tanto a poesia quanto a prosa de Hilda Hilst. ${ }^{1}$

\section{O caminho da paixão: a poesia amorosa de Hilst e a procura da unidade}

Na temática amoroso-sexual hilstiana, podemos constatar uma evolução de tom. Partindo de uma poesia de dedicação lírica ao amado inspirada nas cantigas medievais, ${ }^{2}$ o discurso desemboca, na "trilogia erótica", ${ }^{3}$ na representação dos mais desviantes comportamentos sexuais, combinando sarcasmo, erotismo e humor, como resposta grotesca à absoluta perda de esperança e de sentido com relação ao mundo e ao gênero humano.

A poesia amorosa hilstiana, expressão de uma paixão avassaladora à procura da unidade tanto com o amado como com o Deus-pai, fusiona essas duas representações do outro/Outro, pois a procura pelo amado humano acontece no mesmo tom de ânsia apaixonada que aquela pelo divino.

1 Antes de começar a análise, é necessário esclarecer que, além do eu lírico, interpretamos os protagonistas de Hilst como alter egos, pelo fato de serem, na sua grande maioria, também eles escritores e funcionarem como meras superfícies de reprodução do mesmo discurso, retomado sob diversos ângulos. Justifica-se assim o recurso a depoimentos da autora feitos em diversas entrevistas, paralelamente a trechos da sua obra.

2 Refiro-me à primeira fase lírica, concretamente a "Sonetos que não são" e "Do amor contente e muito descontente" de Roteiro do silêncio (1959), a Trovas de muito amor para um amado senhor (1960), e alguns poemas de Trajetória poética do ser (1963-1966), tudo publicado em Poesia 1959-79, (São Paulo/ Brasília, 1980).

3 O caderno rosa de Lori Lamby (1990), Contos d'escárnio. Textos grotescos (1990), Cartas de um sedutor (1991). 
Essa lírica tem como ponto de partida a tradição do amor idealizado, que se inicia com o amor cortês, passa por Petrarca e Dante e desemboca na estética do romantismo. Nas Trovas de muito amor..., de 1960, a voz amante feminina corteja o seu amado e canta a sua ausência no tom do trovador diante da senhora adorada: “- Ai, quem padece/ De tanto amor/ E em alta chama/ Sua vida aquece? / - Ai, quem seria? / Sendo por vós/ Só poderia/ Ser eu, senhor" (Hilst, 1980, p.235).

O sofrimento pela ausência do amado, de um lado, e, de outro, a afirmação feminina como poeta, espelhando uma tensão na vida feminina entre papel tradicional e realização, são também o motivo principal de Júbilo memória noviciado da paixão (1974):

$\mathrm{Ai}$, que distanciamento, que montanha, que água/ Estes rios fundos, o meu sumo escorrendo,/ Esta chaga, ai, senhor, [...] (Hilst, 1980, p.62)

... Tu sabes, Dionísio/ Que ao teu lado te amando,/Antes de ser mulher sou inteira poeta. (Hilst, 1980, p.77)

A metáfora "o meu sumo", entendida como alusão sexual, é um índice do desenvolvimento progressivo de uma drasticidade no vocabulário erótico.

O recurso ao tratamento medieval do amado por "senhor" nos remete ao Senhor-Deus, o amado divino ausente e procurado dilaceradamente em Sobre a tua grande face (1986):

Tentando te buscar. Porque vives de mim, Sem Nome,/ Sutilíssimo amado, relincho do infinito, e vivo/ Porque sei de ti a tua fome $[\ldots]$

Quisera dar o nome de Roxura, porque a ânsia/ Tem parecimento com esse/ desmesurado de mim/ Que te procura. [...] (Hilst, 1992, p.107-8) 
No fervor da paixão e na ausência, o outro humano e o divino se confundem. Juntando essa observação à análise da prosa hilstiana anterior à "fase pornográfica", ${ }^{4}$ que, como a poesia a partir de Poemas malditos, gozosos e devotos (1984), gira obsessivamente em torno da busca desesperada de um Deus eternamente mudo (e por isso cruel), vemos que o núcleo temático da obra de Hilst é a busca por uma unidade impossível e ansiada tanto em nível divino como em nível humano.

Isso não significa que Hilst, através de seus alter egos, veja o amor humano como caminho para o divino. Ao contrário, a relação amorosa humana mais parece ser obstáculo ao ansiado verdadeiro encontro. ${ }^{5}$ Em A obscena senhora D (Hilst, 1993), a protagonista se retira da "vida conjugal sadia" e da sociedade, como já o fizeram vários protagonistas da prosa anterior, à procura de um contato impossível com o divino. Passa a se negar ao desejo do marido e espanta a vizinhança com gestos obscenos. Também na poesia amorosa, expressão do desejo de fusão com o amado, o que foi a supremacia da vocação poética gradativamente vai se transformando na supremacia do desejo pelo divino. Em A obscena senhora $D$ culmina o tópico do desalojamento da união com o outro humano, provocado pela ânsia por um encontro com Deus.

\section{3. "Amor/Humor": ${ }^{6}$ a transformação da paixão em riso}

A frustração resultante da impossibilidade desse encontro é um dos motivos do deboche dos personagens que é desenvolvido na "trilogia pornô", pois o desejo exacerbado precisa do riso libertador como válvula de escape.

4 Isto é, Fluxo-floema (1970), Qadós (1973), Pequenos discursos e um grande (1974), reunidos em Ficções (1977), e Tu não te moves de ti (1980).

5 A união com o amado humano nunca sacia a sede do infinito por não poder ir além do instante fugidio da fusão carnal. "Não tem nenhuma transcendência por esse lado.” (Hilda Hilst em conversa inédita comigo, 7 abr. 1996).

6 Poema-telegrama de Oswald de Andrade. 
Eu nunca pude levar, vamos dizer, muito a sério a sensualidade. [...] com o tempo e com a maneira dos outros de pensarem a sensualidade, começou a me dar uma graça tão grande, que o outro dia uma amiga minha da Gallimard, francesa, me ligou, falou: Hilda, tem uns amigos meus aqui que querem uma resposta do que você considera realmente erótico. Eu comecei a rir, falei: Clélia, a única coisa que eu vi há pouco tempo e ri tanto, ri tanto que tive que ser hospitalizada, porque eu vi um amigo meu nu num banheiro. [...] Eu ri tanto que eu pensei assim: Alguma vez essa coisa me excitou de alguma maneira, eu não comprendi, comecei a rir, porque - era um membro normal que ele tinha, tava se lavando, não era nada pequeno, era normal - mas aí eu olhei, apontei, falei: Não acredito que teve algum dia que isso me excitou. Aí eu comecei a ter um ataque de riso tão grande, falei: Meu Deus, assim - fui perdendo o ar... Aí, ela comecou a rir tanto que não podia mais falar, estava falando de Paris, falou: Hilda, isso é engraçadíssimo, você teve que ser hospitalizada por causa disso. Me vem sempre assim uma coisa de brincadeira, não sei se é com a idade que te vem um discernimento, uma compreensão [...]

Aí, você separa isso, a paixão, e aí vem as brincadeiras, aí vem o que pode ser um tesão, o que pode ser um interesse sexual, e sempre acaba no riso pra mim agora. Eu nunca consigo legar a sério mais. ${ }^{7}$

[Hilda Hilst] pretende agora escrever para o riso. (Pereira, 1989 , s.p.)

Quando mandei para ele [Jorge Coli] as Cartas de um sedutorlivro que eu gostei muito de escrever e possibilitou que me familiarizasse com uma linguagem mais agressiva - ele me disse: "Hilda, depois de ler o livro, eu fiquei doente oito dias". "Mas você não riu?" - eu disse. E ele: "Mas era para rir?" Eu ria muito escrevendo o Cartas de um sedutor. [...] Outros disseram que o livro era cruel. (Hilst apud Zeni, 1998, p.10)

7 Hilda Hilst em conversa inédita comigo, 7 abr. 1996. 


\subsection{A língua como acesso ao conhecimento}

A primeira das brincadeiras que Hilda Hilst desenvolve em sua incursão pelo humorístico (que, através do grotesco, vai até o cínico) é uma espécie de vingança por causa da derrota sofrida na busca do "samadhi" através da linguagem. A procura dos seus alter egos - os personagens - se espelha no fluxo de consciência construído linguisticamente pela autora. Esta inicia a blasfêmia - entendida aqui no sentido amplo da troça da indagação metafísica -, confundindo voluntariamente seu instrumento, a linguagem, com a língua como órgão físico, que funciona, para o personagem Lori Lamby, como acesso ao conhecimento, ao reconhecimento e ao prazer. Em suas fantasias, a ninfetinha Lori é iniciada por "tios" que lhe proporcionam o triplo prazer do sexo, do conhecimento e do dinheiro: "Depois ele quis passar a língua em mim [...]. Mas será que essa é a língua trabalhada que o papi fala quando ele fala que trabalhou tanto a língua?" (Hilst, 1990a, p.65).

O olhar infantil, que combina a ingenuidade com a perversão polimorfa da qual fala Freud, é usado por Hilst para acessar ao prazer do texto barthesiano ${ }^{8}$ através de um romance construído a partir do duplo sentido da palavra "língua". O acesso impossível ao divino identificado com o conhecimento absoluto, junto com a vontade de zombar da crítica que qualificou sua produção anterior como hermética, levam-na à brincadeira obscena e provocadora da troca da linguagem pela língua.

\subsection{O obsceno como mecanismo de liberação}

Podemos aplicar ao "golpe pornográfico" de Hilda o conceito bakhtiniano da carnavalização entendida como paródia e transgressão. ${ }^{9} \mathrm{O}$ carnavalesco medieval se apropria de maneira burlesca dos

8 Refiro-me à obra O prazer do texto (1987), de Roland Barthes.

9 Refiro-me ao trabalho de Mikhail Bakhtin sobre literatura e carnaval. Obra disponível em português: Cultura popular na Idade Média: o contexto de François Rabelais. São Paulo: Hucitec, 2010. 
símbolos das instâncias opressoras (nobreza e clero), transgredindo barreiras sociais e morais através da chacota e do riso libertador.

Também Hilda se libera do peso do mundo com uma risada sonora. Sem resposta nem respaldo diante da crueldade divina (que tolera o sofrimento na terra) e da superficialidade humana (interessada exclusivamente no próprio prazer), usa a obscenidade transgressora como instrumento de provocação e galhofa. Apropria-se de diversos discursos filosófico-eróticos, assim como de estereótipos pornográficos, e deforma-os parodicamente.

Inserindo-se dessa maneira na tradição libertina do obsceno ou pornográfico usado como arma contra a falsidade do poder, ${ }^{10}$ inaugura o desbocamento feminino (embora por intermédio de máscaras masculinas, adaptando-se às expectativas com relação aos papéis femeninos e masculinos: "porque uma mulher talvez não possa ser tão grosseira. A não ser que seja uma lavadeira..."). ${ }^{11}$ Mesmo assim, Hilda precisa se defender: "Você vê se estas mesmas pessoas [que criticaram a trilogia] pensam que Henry Miller enlouqueceu..." (Hilst apud Coutinho, 1991, p.9). Como primeira autora-mulher, ela chega a chafurdar nos abismos do obsceno, num tom que, em sua ousadia, supera toda a literatura erótica anterior, não só de autoras brasileiras, mas também de alguém como o próprio Miller (que teve de enfrentar durante anos a censura moralista norte-americana).

\subsubsection{O que é o obsceno?}

O palavrão é o solecismo da alma. (Hilst apud Gabaglia, 1990, s.p.)

[...] as pessoas estão fazendo uma confusão muito grande entre pornografia e obscenidade [...] A minha trilogia é obscena. (Hilst apud Francisco, 1991, s.p.)

10 Uma tradição traçável a partir da Grécia antiga, passando por Ovídio, Apuleio, as cantigas d'escárnio galego-portuguesas, Boccaccio, Aretino, a "idade de ouro" da pornografía no século XVIII francês, até Sade, Bataille, D. H. Lawrence e Henry Miller.

11 Hilda Hilst em conversa inédita comigo, 7 abr. 1996. 
Segundo o pesquisador Ludwig Marcuse (1962, p.15-6), o termo "obscenum", na literatura latina, expressa uma aversão estética ("medonho"), moral ("imoral") e vital ("nojento"). Embora, segundo a própria Hilda, uma finalidade das imagens "obscenas" de sua trilogia tenha sido a provocação de "tesão" no leitor, esse sentimento na maioria das vezes é contrariado pelo aspecto humorístico, grotesco ou antiestético das situações descritas. Desse modo, Hilda está usando o termo certo quando qualifica seu texto de "obsceno", pois ele se guia por uma "estética do feio" e do exagero, cujo motivo principal é a desforra.

I agree that sex is no laughing matter. Although I believe that joy is one of the synonyms of sex, and that erotic writing lends itself to a comic approach. Laughter is often the most effective obstacle to sexual arousal. Despite this, humor, which includes the grotesque, the awkward, and the embarrassing occasion in bed, has been a fertile source of themes in erotic fiction. (Perkins, 1976, p.12)

Além de autores de ficção "pornográfica" como D. H. Lawrence, Hilda zomba das próprias expectativas eróticas do leitor. Assim, o riso é mais dela do que do leitor, que virou seu objeto de gozação.

É interessante constatar que, apesar de ela própria definir seu texto como "obsceno" segundo o significado comum do termo, Hilda faz um jogo duplo quando empurra para o leitor toda a responsabilidade pelo obsceno das suas imagens, partindo para uma ideia diferente e quase religiosa do obsceno enquanto falta de humildade.

De repente alguém vê alguém lambendo a xereca de uma mula, pode ser alguma coisa, mas pra mim pode ser engraçado, não é? De eu ter a visão de uma criança por exemplo e não ver obscenidade nisso. E acho que é sempre o olho que empresta a obscenidade. Você pode principalmente rir do obsceno. É muito difícil você levar a sério o obsceno. Eu acho que só rindo $[\ldots]^{12}$

12 Hilda Hilst em conversa inédita comigo, 7 abr.1996. 
Para mim, o obsceno é a lucidez extremada. A Sra. D. era realmente uma mulher obscena pela lucidez absurda. Já sabia tanto de tudo, que a coisa ficava realmente desgastada, inexpressiva. É obsceno você viver como se tivesse conhecido tudo. Quer dizer, o obsceno para mim é mais violento do que o obsceno qualquer, isso do pau do jumento, por exemplo, que eu considero tão obsceno quanto eu imagino o que as pessoas consideram. Mas, o meu sentido de obsceno seria uma lucidez muito grande que faz com que não exista mais a surpresa do existir. Fica obsceno você ser uma pessoa assim, é como se você estivesse ofendendo alguém que você não conhece e que sabe mais que você. É Deus. (Hilst apud Amo$\operatorname{rim} 1995, \mathrm{p} .12)$

\subsubsection{Autor e mercado}

Para Hilda, a lucidez é justamente a barreira que impede seu acesso ao público. Em A Literatura e o mal, Georges Bataille ("O Batalha" em O caderno rosa), fala da impossibilidade constitutiva de toda criação literária e da derrota incontornável do escritor diante da sociedade (Bataille, 1989). Em Hilst, essa derrota é dupla, pois é a derrota de seus personagens na busca metafísica, e é também a de seu objetivo como autora, o objetivo de elevar o leitor. ${ }^{13}$

Isso é o Brasil. Uma pornocracia. Ou você escreve bandalheira, ou você tem que aparecer. [...] aqui no Brasil não se pode transgredir... não se pode falar de morte nem de sofrimento. Aqui no Brasil, ninguém morre. Eles querem a bandalha... [...] Na hora que você toca fundo, é mulher, e teu texto é pensante, eles só faltam te matar... (Hilst apud Gabaglia, 1990, s.p.)

Diante deste absurdo, você, com sua lucidez, só tem três escapatórias: o alcoolismo, o suicídio e o erotismo. Mas por que o riso

13 "Concluí que meu objetivo de elevar o outro não foi nem compreendido, nem lido, nem consumido esse tempo todo. Então resolvi virar a mesa, estou viva e quero ser lida. Além disso, cansei de receber migalhas pelo excelente produto da minha cabeça” (Hilst apud Ciccacio, 1989, p.24). 
não seria uma forma de sobrevivência? (Hilst apud Folha da Praia, 1990, p.2)

A transgressão obscena do interdito, que Hilda usa - na tradição libertina que vai até Bataille - como argumentação a serviço de ideias (Willer, 1986, p.68), isto é, a serviço da crítica social, é seu caminho para o riso. Mas o interdito não é somente uma moral só reinante enquanto dupla, é também e ao mesmo tempo o questionamento ontológico que fere a superficialidade generalizada.

Pensar que tenho ainda que pensar uma nova estória para as devassas e solitárias noites do editor. De um hipotético editor. Enfim todos os editores a meu ver são pulhas. Eh, gente miserável e mesquinha e venal. (Vide o pobre do Hans Haeckel). Morreu porque pensava. Editor só pensa com a cabeça do pau, eh gente escrota! Quando o Hans Haeckel pensou em escrever uma estorinha meninil muito da ingenuazinha pornô para ganhar algum dinheiro porque passava fome àquela época, o editor falou: escabroso, Hans, nojentinho, Hans, isso com menininhas! Mas que monturo de nomes estrangeiros ele publicava às pampas! Que grandes porcarias! Bem. Vamos lá. (Hilst, 1990b, p.103-4)

Com sua virada de mesa, Hilda aproveita, goza e se vinga do fato de que "a única maneira de chamar a atenção é falar de sexo" (Hilst apud Francisco, 1991, s.p.).

\subsubsection{O obsceno como provocação}

Para Henry Miller, encontramo-nos sempre à beira do sono espiritual, moral e psíquico, fato que suscita no autor obsceno a necessidade de forçar um acordar. ${ }^{14} \mathrm{O}$ obsceno na arte tem assim a função de um artifício técnico para nos sacudir para um despertar para a realidade.

14 Em entrevista publicada por Malcolm Cowley (1963, p.153, apud Mainusch, 1970, p.44). 
Hilda usa a mesma terminologia quando diz, bem antes de sua trilogia, que "o homem, num sentido genérico, precisa acordar" (Hilst apud Jornal da Tarde, 1974, s.p.). Sobre O caderno rosa, ela disse: "fiz o possível para chocar os leitores" (Hilst apud Comodoro, 1991, s.p.), afirmando mais tarde: "Com a trilogia [erótica] eu dei uma bofetada para o leitor acordar" (Hilst apud Francisco, 1991, s.p.).

O que leva o leitor a rejeitar o texto como obsceno é esse choque, que não se deve (pelo menos não exclusivamente) a uma antipatia ao prazer, mas muito mais à aversão à repugnância, que é provocada com força muito maior por um realismo implacável do que por moralismos imprecatórios (Marcuse, 1962, p.356). ${ }^{15}$ Hilst leva esse realismo às últimas consequências paródicas quando faz, por exemplo, a pintora Clódia pintar o:

caralho em repouso [de Crasso]. De vez em quando ela dava um beijinho no meu pau. Ele fremia (!). Clódia: ah, vai estragar tudo, amorzinho, fica verme, fica. O pau concretizou-se amarelusco na tela. (Hilst 1990b, p.37)

\subsubsection{Escárnio, sátira e o grotesco}

[O caderno rosa é uma] sátira à própria pornografia, ao relato bem comportado e à literatura infantil. (Hilst apud Prado, 1990, p.4)

Bufólicas [...] é um livro político [...] subvertendo o imaginário [...] (dos) contos de fadas... É tão grotesco que não pode ser considerado pornográfico [...] Insisto que é um livro político, porque é impossível escapar ao momento político que vivemos... temos um presidente que não é presidente (Collor) e considera-se escritor quem não é escritor (Paulo Coelho e Danuza Leão). (Hilst apud Heynemanns, 1992, p.4)

15 Quando L.Marcuse fala de realismo, se refere às descrições de Henry Miller. 
Nada melhor então do que rir desta bandalheira toda lendo as Bufólicas. (Hilst apud Rosa, 1992, p.1)

O escárnio hilstiano usa os meios do humor, da sátira e do grotesco para sua crítica social e política.

Adriano Espínola (2000, p.19-23), num ensaio sobre o grande poeta satírico do barroco brasileiro, Gregório de Mattos, vê a origem do brasileiro "na risada, que conduz ao grotesco, à inversão, ao desbocamento."

[...] somos [...] bons de crítica, de gozação, de (auto) zombaria. [...] Há mais de 300 anos somos, assim, esse Narciso às avessas [...] que cospe na sua imagem e ri de sua miséria.

Gregório de Mattos é quem transporta ao Brasil o poema de escárnio, cujas raízes estão na Grécia e na Roma antigas (em Horácio, por exemplo) e nas cantigas de escárnio e maldizer galego- portuguesas, tradição que se funde, em Gregório, com a influência das sátiras do poeta barroco espanhol Francisco de Quevedo.

Com seu título Contos d'escárnio, Hilda remete diretamente a essa tradição medieval, e sua veia satírica, junto com seu estilo, que vários críticos associam ao barroco, se presta a uma comparação com as sátiras obscenas de Gregório.

Dispensando aqui uma análise da questão do barroco estilístico em Hilst, podemos afirmar que no mínimo sua fantasia pode ser denominada de barroca:

As pinturas de Clódia eram vaginas imensas, algumas, de densidade espessa, outras transparentes, algumas de um rubi-carmim enegrecido mas tênue, vaginas estendidas sobre as mesas, sobre colunas barrocas, vaginas dentro de caixas, dentro dos troncos das árvores, os grandes lábios estufados iguais à seda esticada, umas feito fornalhas, algumas tristes, pendentes, pentelhos aguados, ou iguais a caracóis, de um escuro nobre. A variedade de clitóris era inigualável: pequenos, textura de tafetá brilhoso, mínimos, cra- 
vados de ínfimos espinhos ou grandes, iguais a dedos mindinhos, duros de sensualidade e robustez. Pintava dedos tocando clitóris. Ou dedos isolados e tristes sobre as camas. Ou um único dedo tocando um clitóris-dedo. Dizia ter se inspirado no dedo de Deus da capela Sistina. Aquele do teto. (Hilst, 1990b, p.35)

Esse trecho dos Contos d'escárnio, além da pequena blasfêmia no final, também nos remete ao grotesco. O grotesco, um dos elementos centrais da trilogia hilstiana, ${ }^{16}$ se define por relacionar o cômico com o medonho, passando nesse ato do comedido ao absurdo (ou até demoníaco). Surge na arte como expressão da perda da fé, quando a fantasia passa para o ainda impossível, conjurando a descomposição demoníaca do mundo. Na época moderna, Beckett e Ionesco são mestres do grotesco, como Rabelais fora para o Renascimento.

\subsection{O caminho da perversão: a blasfêmia como avesso da prece}

Em seu estudo sobre a literatura erótica francesa (Bataille, Genet, Pauline Réage, entre outros), Perkins constata que na maioria desses textos há uma relação direta entre o erotismo e um ideário religioso, já que para os protagonistas, a transgressão erótica torna-se o meio de ultrapassagem do isolamento doloroso da individualidade. Essa procura pela unidade com o mundo "is usually religious” (Perkins 1976, p.64-6). Em Hilst, a transgressão erótica como tentativa de união toma o caminho da blasfêmia.

16 O exemplo citado não é o melhor; existem inúmeros trechos na trilogia mais expressivos para essa fusão do cômico com o terrível que caracteriza o grotesco e provoca um riso que não é libertador, mas que fica entalado na garganta. Por exemplo nas Cartas de um Sedutor: "[...] o homem gritou: quero fudê! quero fudê! Amarraram-no a um poste e encheram-no de pauladas. Um cachorro passou por perto e ficou olhando o homem morrer. Depois passou um mocinho e disse sorrindo: é, negão, fudê não pode não. Aqueles que ouviram, gargalharam" (Hilst, 1991a, p.92). 
Quero saber. Então através disso vêm as blasfêmias também [...]. Porque você pode de repente cutucar o tempo todo um tigre, até que chega o momento onde ele te come a mão ou alguma coisa acontece. O terrível é você ficar separado dele o tempo todo e não saber nada dele. Então se você chegar perto dele e começar a agredir, de repente pode te acontecer alguma coisa. [...] [Você se diz:] Não, agora ele vai se manifestar, não pode ser que eu tendo dito tudo isso... Pode ser ingênuo até, mas pode até acontecer, de eu ter um insight, você ter um samadhi, uma coisa que eu nunca tive na vida, um samadhi, de ter compreendido Deus de repente, como tem místicos que tiveram $[\ldots]^{17}$

$\mathrm{Na}$ transgressão obscena, que com a blasfêmia chega ao seu paroxismo, fundem-se ambos os sentidos da palavra escatologia. Na blasfêmia, o texto hilstiano brinca de ser ao mesmo tempo "tratado acerca dos excrementos" e "tratado sobre os fins últimos do homem". ${ }^{18} \mathrm{Na}$ procura da "imagem realmente obscena" (Hilst apud Amorim, 1995, p.12), Hilda e seus protagonistas reagem à mudez divina (e à estupidez humana) através do excesso, da excrecência, do excremento.

L'oeuvre de Hilda Hilst est même prète [... ] a se profaner [...] dans le blasphème, sorte de prière inversée. Mais ce renversement... tient a l'instabilité d'un sujet sans site assigné, en quete d'une attache abolie aussitôt qu'entrevue. [...] Le recours a l'obscenité a le même effet que celui des formules magiques et hermetiques, physiques ou mathematiques... (Olivieri-Godet; Riaudel, 1997, p.30)

Para se livrar do paroxismo da paixão como desejo de união (com o divino), Hilda leva a sexualidade até o obsceno, que vira motivo de riso (quando sátira), de depressão (quando grotesco) ou de revolta (quando blasfêmia).

17 Hilda Hilst em conversa inédita comigo, 7 abr. 1996.

18 Definições de "escatologia" segundo o dicionário Novo Aurélio (Anjos; Ferreira, 1999, p.795). 


\section{Referências bibliográficas}

AMORIM, W. Hilda Hilst: Não tenho alegria de ser brasileira. Suplemento Cultural ao Diário Oficial do Estado de Pernambuco, Recife, ano IX, out. 1995, p.12.

ANJOS, M.; FERREIRA, M. B. Novo Aurélio - século XXI. Rio de Janeiro: Nova Fronteira, 1999.

BAKHTIN, M. Literatur und Karneval. München: Hanser, 1969.

BARTHES, R. O prazer do texto. São Paulo: Perspectiva, 1987.

BATAILLE, G. A literatura e o mal. Porto Alegre: L\&PM, 1989.

CICCACIO, A. M. Novembro, mês fértil para Hilda Hilst. Jornal da Tarde, Campinas, 13 out. 1989, p.24.

COLASANTI, M. E por falar em amor. São Paulo: Ed. Salamandra 1984.

COMODORO, R. O fecho de uma trilogia erótica. Jornal do Brasil, Rio de Janeiro, 2 set. 1991, s. p.

COUTINHO, A. Hilda Hilst - Delícias e Fúria. [sem fonte], 1991, p.8-9.

DENSER, M.; PRADA, C. Muito prazer. Rio de Janeiro: Record, 1980. O prazer é todo meu. Rio de Janeiro: Record, 1984.

ESPÍNOLA, A. O nativismo ambíguo de Gregorio de Mattos. In: Cult.

Revista Brasileira de Literatura, São Paulo, ano IV, n.41, dez. 2000, p.19-23.

FOLHA DA PRAIA. Hilda Hilst. Aracajú, ano X, n.449, 23-29 set. 1990, p.2.

FRANCISCO, S. [sem título]. Jornal de Brasília, Brasília, 04 out. 1991, s. p.

GABAGLiA, M. R. Brincanagens de Hilda Hilst. Diário Popular, São Paulo, 20 out. 1990, s. p.

HEYNEMANNS, L. O fogo da paixão de Mariana e Hilda. Jornal do

Brasil, Rio de Janeiro, 3 out. 1992, p.4.

HILST, H. Bufólicas. São Paulo: Massao Ohno, 1991b.

Cartas de um sedutor. São Paulo: Paulicéia, 1991a.

. Contos d'escárnio. Textos grotescos. São Paulo: Siciliano, 1990b.

. Do desejo. Campinas: Pontes, 1992.

Ficções. São Paulo: Edições Quiron, 1977.

. O caderno rosa de Lori Lamby. São Paulo: Massao Ohno, 1990a.

. Poemas malditos, gozosos e devotos. São Paulo: Massao Ohno, 1984.

. Poesia (1959-1979). São Paulo: Edições Quiron, 1980a.

. Rútilo nada. A obscena senhora D. Qadós. Campinas: Pontes, 1993. 
HILST, H. Tu não te moves de ti. São Paulo: Livraria Cultura Editora 1980b.

JORNAL DA TARDE. Hilda Hilst. Campinas, 23 abril 1974, s. p.

MAINUSCH, H.; MERTNER, E. Pornotopia. Frankfurt: Athenaeum 1970.

MARCUSE, L. Obszön. Geschichte einer Entrüstung. München: List 1962.

MILLER, H. Years of trial $\mathcal{E}$ triumph. Carbondale: Southern Illinois Univ. Press, 1978.

OLIVIEIRI-GODET, R.; RIAUDEL, M. Hilda Hilst et Adélia Prado. In: Pleine Marge. Cahiers de Littérature, d'Arts Plastiques \& de Critique. Paris, n.25, maio 1997, p.29-31.

PEREIRA, J. [sem título] Jornal da Tarde, Campinas, 28 fev. 1989, s. p.

PERKINS, M. The Secret Record. Modern Erotic Literature. New York: William Morrow and Company 1976.

PIÑON, N. A casa da paixão. Rio de Janeiro: Record, 1972.

PRADO, L. A. Lori Lamby, o ato político de Hilst. O Estado de S. Paulo, São Paulo, 14 jun. 1990, p.4.

QUINLAN, S. C. The Female Voice in Contemporary Brazilian Narrative. New York: Peter Lang, 1991.

ROSA, L. Escritor vê a crise com humor e erotismo. Diário Popular, Campinas, 24 set. 1992, p.1.

SCHMALTZ, Y. A alquimia dos nós. Goiânia: Secretaria de Educação e Cultura do Estado de Goiás, 1979. Bacos e Anas brasileiras. Rio de Janeiro: Achiamé, 1985.

WILLER, C. Mergulho cósmico. Istoé, São Paulo, 31 dez. 1986, p.68.

ZENI, B. Entrevista - Hilda Hilst. In: Cult. Revista Brasileira de Literatura, São Paulo, n.12, jul. 1998, p.6-13. 


\section{FaLANDO COM DeUs... ${ }^{1}$}

Michel Riaudel

Há na obra de Hilda Hilst vários desafios lançados ao leitor. Justificar uma unidade não é o menor deles: o tom sublime de poemas como os da coletânea Do desejo parece muito distante das provocações paródicas e obscenas ${ }^{2}$ anunciadas por certos títulos de sua prosa, como A obscena senhora D, Com meus olhos de cão, Contos d'escárnio. Textos grotescos, Cartas de um sedutor... O que haveria em comum entre os endereçamentos ao "Sem Nome" em Sobre a tua grande face e em $O$ caderno rosa de Lori Lamby? Sem dúvida, teremos progredido um pouco na compreensão dessa obra se chegarmos a considerar, em conjunto, seus elementos aparentemente heteróclitos.

1 Tradução do original em francês "Parler à Dieu...".

2 Sobre esse tema, referimo-nos, em particular, ao ensaio de Eliane Robert Moraes, "Da medida estilhaçada", Cadernos de literatura brasileira, dossiê "Hilda Hilst”, n.8, São Paulo: Instituto Moreira Salles, 1999, p.114-26. 


\section{De joelhos...}

Certamente podemos apontar aquilo que interliga esses textos, como a onipresença do corpo, uma convocação do carnal. Metaforicamente ou não, tudo é traduzido para o concreto, encarnando-se no tangível - seja para dizer a ausência ou a desolação. Mas o ângulo temático talvez não constitua uma abordagem das mais eficazes, na medida em que o que se diz é instável. Seria mais produtivo registrar os dispositivos de enunciação, que prontamente mobilizam as pessoas do discurso, como o "eu" e o "você/tu", seja por meio da interpelação ou dos gêneros da esfera íntima. Desse modo, um trecho da obra poética interpela diretamente o interlocutor, ou, por vezes, o desejo, ou algo que poderia se assemelhar a uma transcendência, como Deus:

\section{Quem és? Perguntei ao desejo.}

Respondeu: lava. Depois pó. Depois nada. (Hilst, 1992, p.7, epígrafe)

De tanto te pensar, Sem Nome, me veio a ilusão. (Hilst, 1992, p.105)

O fato de o interpelado permanecer mudo e de essa interlocução ser vã, ou, em todo caso, assimétrica, não exclui a existência ou a inexistência da segunda pessoa, fazendo-nos lembrar dos arranjos místicos onde Tudo e Nada são reversíveis e, portanto, equivalentes.

Michel de Certeau já destacou que o discurso místico emerge de um sentimento de falha na comunicação, de uma "dualidade intransponível” na relação com a linguagem, no silêncio do outro: "a essa ausência do Verbo opõe-se uma certeza: ele deve falar, [mas] aquilo que deveria ser está faltando” (Certeau, 1982, p.217-8). Trazendo à frente do palco uma série de primeiras pessoas, as do caderno rosa e do preto, especialmente aquelas da correspondência entre Lori Lamby e o tio Abel, O caderno rosa adota uma estratégia diferente, que remete a outro dispositivo cristão: a confissão. Lori 
Lamby, uma criança de oito anos, narra uma história que primeiramente se apresenta como uma espécie de diário, ao qual, como qualquer autora de diário, ela confia, no segredo de um tête-à-tête com a folha branca, os momentos mais ou menos confessáveis de sua existência. No entanto, a despeito da candura da narradora, não há nada mais vergonhoso e escandaloso que a iniciação sexual de uma menina com "senhores" libidinosos e pedófilos. A transgressão aumenta na medida em que o diário é escrito sem o conhecimento de seus pais, que, no entanto, parecem organizar a prostituição de sua prole.

$\mathrm{Na}$ verdade, a construção do livro é mais complexa e vertiginosa do que esse resumo sugere, de forma que, embora resistente à descrição, ela merece ser esclarecida. Por um lado, o paralelismo dos dois cadernos é apenas superficial, já que um se intercala no primeiro, em posição, portanto, mais subordinada do que antitética. A oposição é exibida pelo contraste de cores - e, aliás, apesar do título que lhe foi dado por Lori, é um diário falso escrito por Abel, cuja primeira pessoa, Edernir, expõe suas aventuras sexuais: uma paixão de quinze anos pela filha de um farmacêutico (ela mesma uma iniciada, sobretudo por um jovem pároco desdentado, Dédé-o-falado). ${ }^{3}$ Tudo acaba - ou quase - em meio ao caos de uma cena de sodomia, zoofilia e violência. A esses relatos somam-se três cartas do "Tio Abel" a Lori; estão registrados, no diário, respostas e comentários suscitados por tais cartas; uma carta de Lori a seus pais, narrando detalhes secretos do caso depois que descobrem o caderno, além de uma última missiva endereçada ao editor do pai escritor, "Tio Lalau", na qual há quatro fábulas curtas criadas por Lori - para as crianças! A consistência dessa prosa desgrenhada poderia ser assegurada pela voz da menina, o que credencia o título

3 Nota-se que esse nome próprio é composto pela inversão de Ed, abreviação que a moça, Corina, emprega para disfarçar Edernir - como no nome reduzido "Cô", empregado pelo padre para se dirigir a ela durante suas frenéticas travessuras. Mas Corina também é o nome da mãe de Lori, o que expressa, no plano onomástico, uma pequena amostra do que, na obra, são jogos vertiginosos envolvendo pontos de contato, reduplicações, reviravoltas e ressonâncias diversas. 
do livro, se essa continuidade não fosse frustrada pela inserção intempestiva de poemas do pai, e mais ainda pela confissão de Lori de que ela, aqui e ali, plagiara os escritos de seu pai.

[...] então fui lá no teu escritório muitas vezes e lia aqueles livros que você pôs na primeira tábua e onde você colou o papel na tábua escrito em vermelho: BOSTA. E todas as vezes que dava certo de eu ir lá eu lia um pouquinho dos livros e das revistinhas que estavam lá no fundo, aquelas que você e mami leem e sempre estavam dando risada. Eu levei umas pouquinhas pro meu quarto e escondi tudo, também o caderno eu escondi lá naquele saco que tem minhas roupinhas de nenen que a mami sempre diz que vai guardar de lembrança até morrer mas nunca mexe lá. Por que vocês mexeram lá? [...] E também eu peguei alguns pedacinhos da tua história da mocinha, mas fiz mais diferente, mais como eu achava que podia ser se era comigo. [...] Bom, papai, eu só copiei de você as cartas que você escreveu pra mocinha mas inventei o tio Abel. (Hilst, 2005, p.92-5)

Nessa arquitetura à la Escher não se sabe muito bem, afinal, se é preciso "acreditar" no que foi lido - no plano da ficção, evidentemente - ou se não se deve, antes, concluir que tal montagem é criada por um adulto, nesse caso o próprio pai escrevendo uma história pornográfica ${ }^{4}$ - o que ocorre, de fato, se o reconduzirmos ao plano da enunciação. No entanto, qualquer que seja a perspectiva escolhida pelo leitor, o ponto de fuga da confissão é esclarecedor. Não só pelo clima que paira sobre o texto: o despudor calculado e a falsa inocência de Lori chocam-se violentamente com a discrição do diário, oculto aos "adultos" (mas revelado a essa outra figura paternal que é o tio Abel), e concebido, inclusive, por uma menina que escuta atrás das portas. ${ }^{5}$ Em outras palavras, esse texto é profundamente trabalhado pela censura que ele simula com a leveza da ignorância. Aqui

4 "Papi não está mais triste não, ele está é diferente, acho que é porque ele está escrevendo a tal bananeira, quero dizer bandalheira que o Lalau quer" (Hilst, 2005, p.21).

5 "Eu ouvi um pouco atrás da porta" (Hilst, 2005, p.27). 
atua uma das funções do confessional que se dá no silêncio, do qual são extorquidos, em nome de Deus, segredos mais ou menos graves.

Todavia, sobretudo nas incertezas que nós acabamos de assinalar sobre a origem da narrativa, sua aparência enganosa e seus falsos pretextos, aflora uma outra realidade da confissão, que é a antípoda exata da fala mística. Enquanto esta convoca um Outro indeterminado cuja presença se autentifica por meio de estigmas de toda ordem deixados sobre o corpo do crente, a confissão esforça-se para assegurar a veracidade de um discurso sempre sob suspeita de mentira ou de omissão. Assim, a dúvida não paira sobre a segunda pessoa, mas sobre a primeira, possivelmente manipuladora ou sujeita a falhas. Ao mesmo tempo, o cerne do saber se desloca, em um movimento especular que produz o lugar de quem não sabe (tudo). Em um caso, o "você" se oculta; no outro, o "eu" se mascara. Na ausência de maiores certezas, o que garante a exaustividade da fala é a crença no fato de que a confissão se efetua sob o olhar do Deus onisciente, exaustividade também solicitada pelo valor performativo da confissão: já que falar é o primeiro passo do exorcismo que conjura o pecado que está em nós, e já que não podemos esperar senão alívio e absolvição, por que encobrir nossos próprios erros?

\section{Este é meu corpo}

Em suas afinidades com a mística ou com a confissão, os conflitos "transcendentes" da obra de Hilda Hilst sempre se destacam, contudo, do discurso da devoção. Isso não se deve apenas à precariedade de seu fundamento, ou à incredulidade quanto à existência de um Deus, ${ }^{6}$ mas, sobretudo, ao fato de que eles não

6 Veja, sobre isso, o que Hilda Hilst declara em uma entrevista concedida a Cadernos de literatura brasileira: “- A senhora reconhece essas presenças [Sóror Juana Inés de la Cruz e Santa Teresa d'Ávila], embora remotas, na sua literatura chamada "pornográfica"? - É verdade. É a busca de Deus. É por isso que A obscena senhora D pergunta: "Deus, você me entendeu?” (Cadernos, 1999, p. 30). 
compartilham, de modo algum, o saber dos fiéis. Provocadoras ou suplicantes, essas obras são, porém, bem alicerçadas por uma fé: não nos enganemos, todos os livros de Hilda Hilst são livros de sabedoria, que perseguem com convicção uma verdade. Isso, contudo, não tem nada a ver nem com a razão arrazoante, com a demonstração científica, ou com a questão platônica ou cristã da alma. Desse ponto de vista, poder-se-ia chegar à conclusão de um desafio pervertido que não para de estremecer os fundamentos da racionalidade e de arruinar seus edifícios. Ainda que o perverso se contente, por assim dizer, em assediar as brechas do "soberano bem"- como aquela aberta pelo imperativo categórico, sem deixar o terreno da lição ou da demonstração: se o bem é o que se faz ouvir dentro de mim por meio da experiência ${ }^{7}$-, ele pode igualmente ser substituído pelo que dita a voz interior de Madame de Saint-Ange ou de Dolmancé. Em "Kant avec Sade", ${ }^{8}$ Jacques Lacan observou, intuindo uma solidariedade entre elas, que a Kritik der Praktischen Vernunft $(1788)^{9}$ precedeu em apenas alguns anos a publicação de La Philosophie dans le boudoir (1795), ${ }^{10}$ que se pretende um manual de educação feminina. O perverso, como ilustram o Dom Juan molieresco e seu duplo atrapalhado Sganarelle, ainda é algo retórico, o que não é a voz hilstiana. Certamente ela arremeda, parodia, desvia, com artimanha e deleitamento, mas sem jamais renunciar a sua verdade: o gozo.

O caráter oblíquo e fugidio de sua prosa, tanto em sua "dramaturgia" quanto nas sobreposições de voz maliciosas, tornam sua

7 Recordemos o famoso início da conclusão da Segunda Crítica: "Duas coisas preenchem o ânimo (Gemüt) com uma admiração e uma veneração sempre novas e crescentes à medida que a reflexão se vincula e se aplica a elas: o céu estrelado acima de mim e a lei moral dentro de mim". Trecho traduzido a partir da edição francesa: Emmanuel Kant, Critique de la raison pratique, trad. F. Picavet, Paris: Félix Alcan, 1888, p.291.

8 Cf. Jacques Lacan, Écrits II, Paris: Seuil, coll. "Points", 1999 [1.ed.: 1966], p. 244.

9 Tradução em português: Kant, I. Crítica da razão prática. Trad. Valerio Rohden. São Paulo: WMF Martins Fontes, 2011.

10 Tradução em português: Sade, M. de. A filosofia na alcova. Trad. Contador Borges. São Paulo: Iluminuras, 2008. 
natureza complexa de se apreender. É difícil lê-la ao pé da letra, por ser a provocação abalada por risos. No entanto, é isso o que, em algum momento, deve se impor para avançarmos em sua compreensão e em sua interpretação, o que pode até nos ajudar. Pois, se pudemos detectar, anteriormente, os efeitos subterrâneos da censura, é porque sua instância é justamente a do superego. O cômico é o modo subversivo da expressão moral.

Para tentar desembaraçar, nesse campo, os discursos emaranhados de $O$ caderno rosa, podemos distinguir, no plano intradiegético, três polos principais de ética, sobre os quais se articula aquilo que se decifra de uma mensagem emitida secretamente, sobre a própria função literária. Na história, debatem-se ou afrontam-se a ética parental (a ordem do Bem), a lei do mercado (a ordem dos bens) e o imperativo do gozo. A primeira é enquadrada por princípios rígidos cuja transgressão leva seus defensores, ao final do percurso, à loucura e ao internamento. Lembremo-nos das últimas páginas do romance, quando os pais descobrem o "diário" da filha: a mãe desmaia e ambos partem para uma casa de repouso. ${ }^{11}$ Foi então que Lori disse querer ajudar o pai, inventando uma história de sucesso que agrada ao editor Lalau. E, para isso, queria inserir os elementos dos textos achados nos projetos de seu pai.

O objeto da segunda se inscreve, aquém do bem e do mal, nas próprias coisas que substituem os ideais. Sua lei é voltada para a produção e o consumo compreendidos como a própria finalidade do sistema. É, por exemplo, o objetivo do editor Lalau, que pensa nos números de vendas, com base nos quais se determinam as restrições da escrita, como a brevidade do livro. No seu ponto de vista, o escritor deve satisfazer o gosto do público, e deve aceitar, para isso, prostituir sua prosa (tal como prostituir os encantos da filha). Pode-se dizer que ele é motivado pelo desejo de enriquecer, mas a riqueza é um dado relativo, já que a busca por ela não tem

11 É verdade que, no início da história, supõe-se que o pai de Lori lê o seu livro (vide Hilst, 2005, p.25), dado incompatível com os desdobramentos posteriores. 
limites. Assim, não é o dinheiro em si que ele persegue, mas o enriquecimento sem fim, o que equivale a uma agitação permanente e desenfreada. De certa forma, Lori Lamby reproduz esse esquema, fascinada como é pelos modelos midiáticos:

Eu sempre pedia pro gênio trazer salsichas e ovos bem bastante porque eu adoro e também pedia pro papai pedir pro gênio tudo que a Xoxa usa e tem. Papi disse quando eu pedi pra eu deixar de ser mongoloide. (Hilst, 2005, p.18-9)

Contra o ideal espiritual ou aristocrático do pai formula-se uma demanda dupla, em parte alienada pela economia capitalista (e sua sociedade do espetáculo), em parte fundada no prazer dos sentidos (o sabor das salsichas e dos ovos). A alienação é marcada igualmente pelos traços do american way of life (a transformação de "papai" em "papi", de mamãe em "mami", bem como o "y" de "Lori Lamby"). No entanto, um grão de areia sexual apodera-se desse tipo de máquina desejante: em "Lamby", ouve-se "lamber". E em Xoxa, reconhece-se a estrela dos programas infantis, Xuxa, nome artístico alterado para sugerir "xoxota". De modo que a verdade do corpo eclode, como último recurso, e acaba levando a regulação publicitária à implosão.

Deixando, em certo nível de profundidade, os sentidos prevalecerem sobre a significação, a obra de Hilda Hilst promove uma desorganização das estruturas do saber, que não são mais comandadas pelo cérebro e pela razão. Um tanto mais fundo, ela antecipa também certa relação com o literário, em parte mimetizada pela intriga e pela busca de Lori Lamby. ${ }^{12} \mathrm{O}$ propósito aqui joga com dois níveis: por um lado, com o da intriga, e, por outro, com o do referencial intertextual. É simples observar que a discussão entre o pai e Lalau,

12 Nota-se, de passagem, o que sugere a identificação do autor e de sua personagem: a reiteração da opção onomástica ecoando as iniciais dobradas de Hilda Hilst, H. H., que se encontra em Lori Lamby, L. L., e em Hans Haeckel (cf. Contos d'escárnio. Textos grotescos, 1990). De certa forma, reitera-se o eco de Kafka em Samsa... Pode-se considerar ainda a homofonia de Hilda Hilst com Hillé, personagem de A obscena senhora $D$. 
sendo o ponto de vista do editor sustentado pela mãe, e depois, pela filha, grosso modo opõe uma literatura alimentar, à base de receitas, como o best-seller, que supostamente bajula as infames inclinações dos leitores, a uma outra concepção de escritor: exigente, indigente, sem público, angustiado diante da página em branco. A sacralização do literário é o corolário de uma figura de exceção, frágil, doando sua vida e sua pessoa à arte, praticando sua atividade não como profissão, mas como sacerdócio, tal como Gustave Flaubert.

Porque só teve essa madame Bovary que deu certo, e se você gosta tanto do Gustavo, lembre-se do que ele disse: um livro não se faz como se fazem crianças, é tudo uma construção, pirâmides etc., e a custa de suor de dor etc. (Hilst, 2005, p.70)

É o que responde o pai à esposa durante uma briga. Ela o acusa de só falar sobre sexo em termos infantis; ele retruca dizendo que se trata apenas do começo de uma história, preparando uma narrativa mais crua, mais direta.

\section{Sereis minhas testemunhas}

Dito de outra forma, a cena representa, em um abismo invertido, o que se efetiva sob a caneta de Lori Lamby. Porém, nos dois casos, considerando-se a autora filha ou o autor pai, o texto é o resultado de uma demanda endereçada a partir do lugar do Outro (demanda implícita do pai, do ponto de vista de Lori; da mãe ou do editor, do ponto de vista de "Papi"), do qual, como leitores, somos o outro convocado a testemunhar, encerrados nas redes de um diálogo que não nos diz respeito, mas que também é termo de um discurso transferencial, o da literatura, única instância capaz de recusá-lo em suas perlaborações potenciais.

Contudo, de alguma forma a família que emerge do intertexto, cúmplice entre a ironia e a homenagem, está aí para guiar nossa leitura. O caderno rosa alterna citações eruditas com menções amigáveis, tais como as dos tios Dalton (Trevisan) ou Millôr 
(Fernandes), ${ }^{13}$ autor das ilustrações da primeira edição da Massao Ohno. Desde então sempre presentes, elas são inseparáveis do texto, no qual transmitem a mistura de infantilidades, de pornografia, de histórias em quadrinhos, gênero adorado pelas crianças, e de sofisticação. Entre os familiares mais distantes, são citados explicitamente Catulo e Marcial, poetas contemporâneos de Cícero, no caso do primeiro, e de Quintiliano, no caso do segundo, e que, rompendo com a retórica oficial, na contracorrente do grandioso gênero épico, destacam-se especialmente por seus versos sarcásticos ou obscenos. A adaptação livre da página 73 se inspira no poema XL das Euvres de Caio Valério Catulo, "À Ravidus": "Que má ideia, meu pequeno Ravidus, precipitar-te assim ao encontro dos meus iambos? Que deus inspira-te a ideia maluca de incitar uma discussão?". ${ }^{14}$ Enquanto na página seguinte há uma transposição de "Contra Fabullus", o poema LXXXVI do livro Euvres complètes de M. Valerio Marcial: "Os pederastas têm, dizes tu, o hálito forte: se é como dizes, Fabullus, que cheiro devem ter, diz-me, aqueles que lambem?". ${ }^{15}$

Identificam-se igualmente alusões mais ambíguas ou cáusticas aos monstros sagrados da literatura moderna contemporânea.

13 Cf. a carta que Lori escreve a seus pais: "Eu também ouvia tudo o que você e mami e tio Dalton, e tio Inácio e tio Rubem e tio Millôr falavam nos domingos de tarde. Eu acho lindo todos esses tios que escrevem" (Hilst, 2005, p.95). Pode-se associar o nome "Rubem" a Braga ou a Fonseca. A identificação por trás do "tio Inácio", se é que tenha uma alusão, se mantém enigmática.

14 Catulle, Euvres, trad. Maurice Rat, Paris: Garnier Frères, 1931, p.58-59 ("Ad Ravidum. Qucenam te mala mens, miselle Ravide/ Agit precipitem in meos iambos?/ Quis Deus tibi non bene advocatus/ Vercordem parat excitare rixam?”).

15 (N. do T., na tradução francesa: "Les pédérastes ont, dis-tu, l'haleine forte: si la chose est comme tu le dis, Fabullus, que doivent sentir, dis-moi, ceux qui lèchent”.) M. V. Martial, Euvres complètes, trad. V. Verger, N.-A. Dubois et J. Mangeart; nouv. éd. revue par Félix Lemaistre et N.-A. Dubois, Paris: Garnier frères, 1864, p.274 ("In Fabullum. Padiconibus os olere dicis. / Hoc si, sicut ais, Fabulle, verum est, / Quid tu credis olere cunnilingis?”). A tradução francesa suaviza a última palavra, que se relaciona aos "chupadores" do sexo feminino, ou, em outras palavras, nesse contexto, à prática considerada mais depreciada. Vejamos o poema XXX do Livro XI: "CONTRA ZOILE. Tu afimas, Zoile, que a boca dos advogados e dos poetas cheira mal; pois a boca de um chupador sem vergonha cheira muito pior." 
Como os que são espontaneamente associados à transgressão erótica: D. H. Lawrence, Henry Miller ou Georges Bataille, nos quais as aparições mais ou menos sub-reptícias são enquadradas por um contexto relativamente degradante. ${ }^{16}$ É o destino do autor de Lady Chatterley's Lover: ${ }^{17}$ uma frase, a ele associada, serve de epígrafe ao "Caderno negro", cuidadosamente copiada por Lori: "Seu pênis fremia como um pássaro" (Hilst, 2005, p.41).

Não obstante, o lirismo que eleva a temática sexual (e decerto assume um leve tom de ridículo) é interrompido pelo contraponto que detona os dois enunciados seguintes, em que a trivialidade minimalista situa-se entre a gargalhada e a excitação jubilosa, à escolha do leitor:

Hi, hi!

(Lori Lamby)

Ha, ha!

(Lalau)

Miller e Bataille surgem em uma breve sequência, ${ }^{18}$ em que o romancista norte-americano está presente apenas pelo seu primeiro nome, precedido de artigo - "o Henry" - enquanto o sobrenome do autor de Le Bleu du ciel ${ }^{19}$ é "traduzido" em português: "o Batalha". Tantas marcas de uma familiaridade dessacralizante e tantas de desmistificação de figuras célebres já foram vistas na menção de "o Gustavo": Flaubert, o autor hors-concours da modernidade, concentra a dupla marca infame do artigo e da "tradução".

O corpus literário brasileiro não é poupado pela erosão sarcástica que arrasa dois monumentos do romance do século XIX: Machado

16 Para não falar de Vladimir Nabokov, cuja Lolita, obviamente, vem à mente quando se trata da "história de uma ninfetinha" (Hilst, 2005, p.26).

17 Tradução em português: Lawrence, D. H. O amante de Lady Chatterley. Trad. Sergio Flaksman. São Paulo: Companhia das Letras, 2010.

18 Hilst, 2005, p.85.

19 Tradução em português: Bataille, G. O azul do céu. Trad. Maria Lúcia Machado. São Paulo: Brasiliense, 1986. 
de Assis é rebaixado a um nome de rua, onde mora Juca, também chamado de José de Alencar da Silva (Hilst, 2005, p.80). ${ }^{20}$ Mais sutis e corrosivas são as referências a duas mulheres contemporâneas: por um lado, o intertexto significativo com a história infantil de Clarice Lispector, A vida intima de Laura. A seu modo, o romance de Hilda Hilst também é uma história de criança, assegurada por uma narradora cujo nome de batismo parecer ser derivado daquele da heroína clariciana. Por fim, o nome de sua mãe, Cora, ${ }^{21}$ direciona um gesto de desdém à popular e consensual poetisa Cora Coralina (1889-1985). ${ }^{22}$

O mais hermético de todos os diálogos intertextuais poderia ser também, no entanto, o mais central e o mais esclarecedor. Isso porque os pontos em comum com Sade são de tal ordem que nos convidam a ler $O$ caderno rosa como uma forma de anti-Filosofia na alcova. Se nos dois casos o sexo é desvinculado da reprodução, ele não o é em ambos pela mesma razão: Madame de Saint-Ange e Dolmancé recomendam deliberadamente a extinção da espécie humana. ${ }^{23}$ Lori não tem idade suficiente para levantar essa questão. Mas, como Eugénie, ela é ávida por aprender um novo vocabulário, motivada pela mesma curiosidade lexical. Façamos a comparação:

Mami me ensinou que a minha coisinha se chama lábios. [...] Eu não sei o que é mongoloide, depois vou procurar no dicionário que eu tenho. (Hilst, 2005, p.18-9.)

e:

O que quer dizer essa expressão "puta"? Me desculpe, mas você sabe? Estou aqui para me instruir. ${ }^{24}$

20 Em posição de sufixo, o "da Silva", vem rebaixar o clássico "José de Alencar".

21 "Cora é o nome da mami”, explica Lori (Hilst, 2005, p.69).

22 Do mesmo modo que a personagem da tia Gilka (vide Hilst, 2005, p.91) evoca o nome de sua contemporânea, a poetisa simbolista Gilka Machado (18971980).

23 Vide Madame de Saint-Ange no terceiro diálogo: "Uma linda moça deve se preocupar apenas em foder e jamais em procriar".

24 Eugénie, no terceiro diálogo: "Qu'entends-tu par cette expression de putain? Pardon, mais tu sais? je suis ici pour m'instruire” (Sade, 1795, p.48). 
ou ainda:

[...] eu vim aqui para aprender e não vou embora sem me tornar uma sábia. ${ }^{25}$

Tanto a inocência de uma como da outra ${ }^{26}$ multiplicam inclusive o efeito explosivo da situação, tal como ressalta Dolmancé: "essa ingenuidade me deixa com um tesão terrível". ${ }^{27}$

Outro ponto comum entre essas histórias é a idade de certos protagonistas, como os 15 anos de Edernir, de Corina, e de Eugénie. O que nos leva a pensar que o "caderno preto" é o inverso sadiano do "caderno rosa", hipótese reforçada pelos pesadelos que sua leitura desencadeia em Lori. Essas aventuras são estranhas a seu universo: "eu achei muito difícil essa história que o senhor me mandou, e também não sei direito como é um jumento preto" (Hilst, 2005, p.65). Se Edernir descobre gradualmente a mentira, a hipocrisia, a violência, que acabam em parte por dominá-lo, Lori mantém um olhar ingênuo que desnuda o absurdo do mundo. A partir de sua janela, a sociedade dos homens pode se tornar melhor, como declara Abel: "Você é impressionante, Lorinha, muito inteligente mesmo, e quer saber, Lorinha? Você me faz sentir que eu não sou mau" (Hilst, 2005, p.34). ${ }^{28}$

25 Eugénie, no segundo diálogo: “je suis venue ici pour m’instruire et je ne m’en irai pas que je ne sois savante” (Sade, 1795, p.19).

26 "Eu vou contar tudo do jeito que eu sei porque mamãe e papai me falaram para eu contar do jeito que eu sei”, declara Lori à guisa de introdução (Hilst, 2005, p. 13).

27 "cette ingénuité me fait horriblement bander", no terceiro diálogo (Sade, 1795, p.32).

28 Em se tratando do Bem e do Mal, seria possível também analisar a escolha do nome Abel, que foi, inclusive, esclarecido no intercâmbio com Lori (vide Hilst, 2005, p.31), bem como o deslizamento hipocorístico-metonímico ("o Abelzinho", em Hilst, 2005, p.37) para designar o sexo masculino. 


\section{Não há relação transcendente}

Em Sade, Eugénie é principalmente uma "vítima" ${ }^{29}$ e as ações são execuções, ${ }^{30}$ enquanto o que se limita à maldade do outro, na ficção de Lori, é seu próprio prazer. Se, por um lado, a "natureza" sadiana faz uma regra da vontade desavergonhada pelo poder, o valor lambyano repousa sobre o apelo sem complexo (mas não sem inquietude) ao gozo. É por isso que o teatro da alcova se constitui de um esqueleto para suas mensagens e lições, ao contrário das travessuras pueris do diálogo que Lori busca dominar:

Eu expliquei que estava escrevendo a minha história e que precisava ter conversa na história porque as pessoas gostam de conversas. [...] Mas não teve muitos diálogos para eu colocar aqui. [...] Fiz bastante diálogo, e agora vou continuar sem diálogo. (Hilst, 2005, p.28-9, 31, 35)

E se os personagens do Marquês exibem ostensivamente o seu ateísmo, os textos de Hilda Hilst, experimentando em todas essas modalidades discursivas e posições de enunciação, parecem buscar o esgotamento da possibilidade de Deus.

A prosa e poesia hilstianas, obscenas ou sublimes, marcadas pela interpelação, pela confissão, por falsas confidências, pela narrativa, pelo teatro e por voos líricos, resultam sempre em uma postura iniciática cujo mestre não conhece senão a experiência do corpo, ou do significante que o representa. Seu saber é a construção de ausências, ilusões, brechas e interrupções no trabalho com o negativo: aquilo que não para de não se escrever. ${ }^{31}$ Jamais se acaba realmente com Hilda Hilst.

29 Vide a réplica da Madame de Saint-Ange a seu cúmplice no terceiro diálogo: "Dolmancé, tire você mesmo a roupa da vítima".

30 Madame de Saint-Ange à Eugénie, sempre no terceiro diálogo: "Me diz qual é a sensação que você vai ter quando nossas línguas forem enfiadas, ao mesmo tempo, nas tuas duas aberturas (Em execução.)". Ênfases minhas.

31 Cf. a definição que Jacques Lacan propõe para a relação sexual, Le Séminaire. Livre XX. Encore, 1972-1973, Paris: Seuil, coll. "Points", 1975, p.193. 


\section{Referências bibliográficas}

BATAILLE, G. Le Bleu du ciel. Paris: Gallimard, 1991.

. O azul do céu. Trad. Maria Lucia Machado. São Paulo: Brasiliense, 1986.

CADERNOS de Literatura Brasileira - Hilda Hilst. São Paulo: Instituto Moreira Salles, n.8, out. 1999.

CATULLE. Euvres. Trad. Maurice Rat. Paris: Garnier Frères, 1931.

CERTEAU, M. de. La Fable mystique (XVI ${ }^{-}$-XVII ${ }^{e}$ siècles). Paris: Gallimard, coll. "Tel”, 1982, p.217-8.

HILST, H. O caderno rosa de Lori Lamby. Ilustração Millôr Fernandes.

São Paulo: Globo, 2005. . A obscena senhora D. São Paulo: Globo, 2001a. . Cartas de um sedutor. São Paulo: Globo, 2001b. . Do desejo. Campinas: Pontes, 1992.

. Contos d'escárnio. Textos grotescos. São Paulo: Siciliano, 1990. . Com meus olhos de cão e outras novelas. São Paulo: Brasiliense, 1986.

Sobre a tua grande face. São Paulo: Massao Ohno, 1986.

KANT, I. Kritik der Praktischen Vernunft. Hamburg: Felix Meiner, 2003. Crítica da razão prática. Trad. Valerio Rohden. São Paulo: WMF Martins Fontes, 2011.

LACAN, J. Écrits II. Paris: Seuil, 1999.

Le Séminaire. Livre XX. Encore, 1972-1973. Paris: Seuil, 1975.

LAWRENCE, D. H. Lady Chatterley's Lover. London: Heinemann, 1961. . O amante de Lady Chatterley. Trad. Sergio Flaksman. São Paulo: Companhia das Letras, 2010.

LISPECTOR, C. A vida intima de Laura. Rio de Janeiro: José Olympio, 1974.

MARTIAL, M. V. Euvres complètes. Trad. V. Verger, N.-A. Dubois e J. Mangeart. Nova edição revista por Félix Lemaistre e N.-A. Dubois. Paris: Garnier Frères, 1864.

MORAES, E. R. Da medida estilhaçada. In: Cadernos de literatura brasileira - Hilda Hilst. São Paulo: Instituto Moreira Salles, n.8, out. 1999, p.114-26.

SADE, M. de. La Philosophie dans le boudoir. Londres: Aux dépens de la Compagnie (2v.), 1795, v.1.

. A filosofia na alcova. Trad. Contador Borges. São Paulo: Iluminuras, 2008. 


\section{Os AUTORRETRATOS NA LÍRICA DE HILDA HILST}

Elaine Cristina Cintra

Como se tudo o mais me permitisses A mim me fotografo nuns portões de ferro Ocres, altos, e eu mesma diluída e mínima No dissoluto de toda despedida.

(Hilst, 2004, p.43).

Toda obra lírica é, em sua essência, uma fala de si. Em gradações múltiplas, por razões históricas ou por objetivos específicos, a lírica é a manifestação literária mais proeminente do eu, o espaço privilegiado da expressão do sujeito em seu âmbito mais pleno. "A subjetividade lírica, por natureza introvertida, é essencialmente narcisista" (Combe, 2009-2010, p.115), mesmo que esse narcisismo se revista em diferentes espectros, como a romântica confissão íntima de momentos vividos que Goethe (1986) preconizava em Poesia e verdade, ou a expressão e a síntese superior da interioridade de uma individualidade incontestável que Hegel (2004) admitia como essência do gênero lírico. Se, no momento moderno, o sujeito lírico supostamente tornou-se um "Eu fragmentário, descontínuo, especialista em fugas, iniciado em lutos" (Benn, 1985, p.8), e a expressão lírica moderna implicava ceder a regras como as que $\mathrm{T}$. S. Eliot recomenda em "Tradição e talento individual" como ideal 
para a evolução do artista, tais como "um contínuo autossacrifício, uma contínua extinção da personalidade” (Eliot, 1989, p.42), impondo uma "teoria impessoal da poesia", o gênero lírico, de maneira sutil ou escancarada, sempre traz à cena a trama da subjetividade.

Nesse trajeto de inscrição de uma subjetividade, ou da fratura dessa subjetividade, o poema lírico apropria-se algumas vezes de formas de escritas de si, tais como o diário, o autorretrato, as confissões, as cartas, entre outras que fazem parte daquilo que Leonor Arfuch (2010) afirma compor o "espaço biográfico", conceito que ela encena a partir das teorias de Lejeune e Bakhtin, e que se vincula a uma ideia de simultaneidade, buscando

[...] relações, em presença e ausência, entre formas com grau diverso de proximidade, relações nem necessárias nem hierárquicas, mas que adquirem seu sentido precisamente num espaço/temporização, numa simultaneidade de ocorrências que por isso mesmo podem se transformar em sintomáticas e serem suscetíveis de articulação, ou seja, de uma leitura compreensiva no âmbito mais amplo de um clima de época. (Arfuch, 2010, p.58) ${ }^{1}$

Os exemplos da inserção dessas formas na lírica são significativos na literatura brasileira, tais como as confissões de Gregório

1 Arfuch propõe que as seguintes "formas" autobiográficas podem ser encontradas nesse "espaço": "biografias, autorizadas ou não, autobiografias, memórias, testemunhos, histórias de vida, diários íntimos - e, melhor ainda, secretos -, correspondências, cadernos de notas, de viagens, rascunhos, lembranças de infância, autoficções, romances, filmes, vídeo e teatro autobiográficos, a chamada reality painting, os inúmeros registros autobiográficos da entrevista midiática, conversas, retratos, perfis, anedotários, indiscrições, confissões próprias e alheias, velhas e novas variantes do show (talk show, reality show), a videopolítica, os relatos de vida das ciências sociais e as novas ênfases da pesquisa e da escrita acadêmicas" (2010, p.60). Essa autora reconhece que há indubitavelmente um "retorno do autor" (contrapondo-se à ideia de morte do autor de Barthes), o que inclui os "bastidores" da criação literária. Assim, considera também as entrevistas, a confissão antropológica ou o testemunho, ou seja, aquilo que chama de "ego-histórias", expressão tão contemporânea e tão contraditória, e que, em sua maior parte, se dão no espaço midiático. 
de Mattos, a poesia autobiográfica de Drummond, os testamentos e epitáfios de Jorge Wanderley, as cartas e diários poéticos de Ana Cristina César, os autorretratos, diários e autobiografias de Armando Freitas Filho, os balanços de Paulo Henriques Britto e, mais recentemente, de Antonio Cícero. Essas manifestações do eu no texto lírico trazem à tona importantes dilemas que perpassam as teorias da poesia, pois polemizam as incômodas referências biográficas no gênero, que se tensionam todo o tempo com a inalienável força da linguagem lírica. No intercâmbio entre um e outro, formula-se uma irresoluta questão sobre o sujeito lírico e seus deslimites.

Certo, porém, seria dizer que no século XX esse cenário parece ter se intensificado, não somente pelas explícitas cadências metalinguísticas da poética moderna, mas também pelos exercícios cada vez mais ousados de revide do sujeito, que, colocado sob suspeita em várias instâncias ideológicas, ainda insiste em dizer na lírica que aí se encontra seu gesto mais absoluto.

Essa é uma das questões imprescindíveis que circundam a obra da paulista Hilda Hilst, poeta que começa a escrever nos anos 1950 e prossegue pelos 50 anos subsequentes, sob influência de autores que comungaram e divulgaram a estética moderna, consolidando-se como uma autora de subjetividade densa, expressa em uma linguagem de tessitura fortemente imagética e mítica.

Hilda Hilst estreia em um momento em que a poesia brasileira se deixava conduzir por uma direção estetizante, marcada por uma geração que idealizava a "poesia pura" em um momento de conflitos políticos desagregadores não somente no país, mas também no panorama mundial. Diante dessa configuração histórica, a autora publica Roteiro do silêncio (1959), registrando o desconforto desse tempo já na primeira seção do livro, denominada "É tempo de parar as confidências". Nesta que será considerada por Hilst sua primeira obra poética de fato, o poeta, "assombrado com as ausências" (Hilst, 1980, p.250), decide "fazer parte da paisagem" (Hilst, 1980, p.250), o que o levará ao pressuposto silêncio de suas expressões subjetivas. No entanto, as outras partes do livro se voltam para uma 
das constantes da poesia hilstiana, a lírica amorosa, que de modo algum consegue abolir as "confidências". ${ }^{2}$

As "confidências" voltam em 1961, quando Hilst publica Ode fragmentária, cujo primeiro poema, "Testamento lírico", pode ser considerado uma "autobiografia", termo aqui tomado não exatamente em sua especificidade, mas a partir da concepção de uma narrativa que não destaca fatos de uma vida, mas as escolhas e perplexidades que derivaram em expressão poética:

Se quiserem saber se pedi muito

Ou se nada pedi, nesta minha vida, Saiba, senhor, que sempre me perdi $\mathrm{Na}$ criança que fui, tão confundida. À noite ouvia vozes e regressos.

A noite me falava sempre sempre

Do possível de fábulas. De fadas.

O mundo na varanda. Céu aberto.

Castanheiras douradas. Meu espanto

Diante das muitas falas, das risadas.

Eu era uma criança delirante.

Nem soube defender-me das palavras.

Nem soube dizer das aflições, da mágoa

De não saber dizer coisas amantes.

O que vivia em mim, sempre calava.

E não sou mais que a infância. Nem pretendo

Ser outra, comedida. Ah, se soubésseis!

2 Esse primeiro silêncio de Hilda Hilst, silêncio que mesmo pressupondo a negação da fala ainda encontra o que dizer no discurso poético, encontrará seu segundo momento quando, em protesto à situação política do país, a autora recusa-se a publicar poesia lírica durante um período de doze anos (1962 a 1974), voltando-se para a escrita do teatro e da ficção. Fica patente, nesse protesto, a vocação política dessa poesia que grita em seu silêncio, o estraçalhamento do sujeito em uma sociedade que não permite a liberdade de sua expressão mais íntima. 
Ter escolhido um mundo, este em que vivo,

Ter rituais e gestos e lembranças.

Viver secretamente. Em sigilo

Permanecer aquela, esquiva e dócil.

Querer deixar um testamento lírico

E escutar (apesar) entre as paredes

Um ruído inquietante de sorrisos

Uma boca de plumas, murmurante.

Nem sempre há de falar-vos um poeta.

E ainda que minha voz não seja ouvida

Um dentre vós, resguardará (por certo)

A criança que foi. Tão confundida. (Hilst, 1980, p.208)

"Testamento lírico" é um poema que descreve as camadas mais densas e essenciais de um sujeito, para explicar as particularidades de sua poesia. De certa forma, aos moldes do Bildungsroman, pode-se dizer que esse poema é uma poesia de formação, no qual a essência de uma personalidade poética é exposta em seus passos mais decisivos, e os fatos da vida são inseridos para justificar as escolhas da escrita lírica. O "testamento lírico" deixa para o leitor o retrato de uma poeta imersa em seu autoconhecimento e na busca de uma expressão poética legítima e sincera. Eis a confidência, o primeiro gesto da escrita moderna sobre si mesmo, que Rousseau consagrou em suas Confissões, voltando à cena para desvendar não somente o eu que se representa em uma linguagem lírica, mas os próprios meandros dessa linguagem em sua formação.

A partir de Júbilo, memória, noviciado da paixão (1974), livro em que retorna ao gênero lírico, Hilda Hilst assume novamente o intimismo, o qual, de fato, nunca abandonou, e seu poema aproxima-se mais extensivamente das formas de escritas do eu. A construção de uma poética amorosa, que de imediato revigora o gesto confessional lírico, é aprofundado não somente na necessidade de uma descrição do eu em seus estados mais vulneráveis e importantes, mas também na afirmação da identidade feminina, que busca uma voz poética para se colocar diante de um jogo amoroso. 
Neste sentido, é pertinente afirmar que, em muitos momentos, a linguagem poética de Hilst apropria-se dessas formas, e que o autorretrato se destaca dentre essas expressões, trazendo à cena aparições de um ser que se compõe na tessitura do discurso poético ao se descrever em seus anseios, suas perplexidades e suas nuances movediças.

Portanto, é a partir da hipótese de que a obra de Hilda Hilst é perpassada continuamente e com bastante regularidade por autorretratos líricos que este trabalho se desenrola. Pretende-se aqui questionar, através da análise de alguns autorretratos, como essa forma de escrita do eu torna-se um procedimento significativo na construção poética da autora e leva o leitor a se questionar sobre alguns parâmetros da lírica do século XX, tais como: de que forma essas expressões (re)configuram a subjetividade poética do século $\mathrm{XX}$; ou, como os autorretratos tornam-se procedimentos significativos na construção poética da autora ou mesmo nos levam a conceber uma hipótese sobre os modos como a lírica moderna se apropria dessa forma artística e sobre a reflexão a respeito do sujeito lírico nessa poesia.

Para isso, é interessante apresentar primeiramente quais concepções e teorias guiaram as leituras do texto hilstiano aqui expostas, a partir da revisão de algumas reflexões sobre o autorretrato.

\section{Os autorretratos e seus reversos}

O autorretrato se define como uma das formas de se representar a si mesmo, a partir de uma necessidade premente de documentar uma possível identidade. Gênero marcado pela estaticidade, pois, ao contrário da dinâmica da narrativa - o ato da representação se faz a partir da fulguração de um "eu" congelado em um tempo e espaço -, esta expressão artística, no âmbito da literatura, propõe-se como relacional: ela utiliza mecanismos da arte pictórica para se compor, impondo-se, à princípio, como um exercício comparativo de interartes. Assim, nessas perspectivas, que se interseccionam, 
analisar um autorretrato literário é remetê-lo às artes plásticas e, evidentemente, à fotografia.

Da mesma forma, o autorretrato é duplo e dúbio em sua concepção artística, e, como afirma Lejeune (2008), o eu, nessa expressão, apresenta-se como autor e como modelo. A propósito, poderíamos acrescentar a esse desdobramento uma terceira instância, a imagem: no autorretrato, o que temos é uma reincidência do eu em várias camadas, que passam do referencial ao simbólico.

Para se instituir como sujeito, o eu funciona, no autorretrato, como espelho e espetáculo. Mas tal espetáculo não se dirige somente a si próprio. Ao se captar em uma imagem, tornar-se representação, o ato narcísico acaba por pleitear um interlocutor. $\mathrm{O}$ autorretrato não somente concentra-se na construção de uma autoimagem, mas indica uma forma de sociabilidade. A própria tradição da fotografia implica essa via de mão dupla, já que, como forma de identificação, segundo Pimentel (2005), originou-se dos processos criminais para identificação de suspeitos. A princípio objeto de controle, hoje, mais do que artefato indicial e icônico, a fotografia é uma das formas de afirmação social, a partir da visibilidade que preconiza e que acaba por ser supostamente o principal modulador da subjetividade nos dias atuais.

$\mathrm{Na}$ atualidade, a incidência de autorretratos, disseminados contínua e exaustivamente pela rede em selfies que documentam toda e qualquer ação e estados corriqueiros, indica o que Pimentel (2005) apresenta quando pressupõe no autorretrato uma maneira de afirmar as identidades em crise na atualidade:

A fragmentação das paisagens culturais de classe, gênero, sexualidade, etnia, raça e nacionalidade, que anteriormente haviam fornecido as bases para o reconhecimento dos indivíduos sociais, parece ter deixado espaço para outras formas de identificação mais rasas. Esta mudança afeta também as identidades pessoais, abalando a ideia que se tem de si próprio como indivíduo integrado. Em seu lugar surge um sujeito que abdica do seu corpo como meio de relação com o mundo e se hibridiza com a tecnologia 
que o cerca. Sua ação e presença não se limitam somente ao espaço e tempo presentes, relativizando a possibilidade de percebê-lo ou defini-lo a partir de sua presença física no mundo. Nesse contexto, o autorretrato e as obras autorreferenciais, pensados como discursos onde o artista contemporâneo desenvolve uma reflexão sobre o sentido do "eu", apresentam-se como formas propícias para o entendimento de como esse sujeito contemporâneo se percebe. (Pimentel, 2005, p.2)

Essa reafirmação de uma identidade em crise, ao ser rastreada na literatura que se realiza a partir do século XX, explicaria a explosão das escritas do eu neste momento, uma vez que deriva de uma concepção de subjetividade que é a "de um sujeito não essencial, constitutivamente incompleto e, portanto, aberto a identificações múltiplas, em tensão com o outro, o diferente, através de posicionamentos contingentes que é chamado a ter" (Arfuch, 2010, p.80). Em outras palavras, um sujeito que necessita construir-se por artifício para se perceber sendo.

A busca de identificações leva a um movimento obsessivo de exteriorização. Dessa forma, aquele que se autorretrata propõe-se como espetáculo a si e ao outro, pela sua necessidade de autodefinição, e, por conseguinte, autocriação. Ao se desdobrar em imagem, o sujeito que se autorretrata estabelece um pacto com o outro, pois a imagem é sempre exteriorização, e, portanto, é desse olhar alheio de si mesmo ou da perspectiva do outro que sua identidade é tecida.

A literatura, ao imiscuir entre suas expressões as diferentes formas de escrita do eu, torna-se um instrumento valioso, possibilitando a este sujeito in constructo, paradoxalmente, recursos ficcionais para essa autorreferenciação. Assim, diários, cartas, confissões, autobiografias, memórias, ao serem apropriados pelo discurso literário, imprimem novas possibilidades para a construção do eu, desestabilizando as fórmulas estabelecidas e propiciando novas e inusitadas possibilidades de se experimentar o "real".

Nesse sentido, o autorretrato se destaca por ser uma forma de escrita de si que frequenta com bastante assiduidade o discurso lite- 
rário, e é nas modulações líricas que encontra suas mais efetivas expressões. Para Clara Rocha, o autorretrato, escrita ordenada lógica e tematicamente e não cronologicamente, é a forma autobiográfica que mais se aproxima das designações do gênero lírico, pois é um tipo de expressão em que se destaca o "estatismo descritivo e reflexivo", diferentemente da narrativa, que requer um fluxo contínuo e dinâmico.

Pimentel (2005, p.11) admite que "há no autorretrato algo que escapa na narrativa". O que escapa à narrativa e que a lírica realiza é justamente a possibilidade de fazer o sujeito se tornar totalmente linguagem, pois a subjetividade sempre se diz melhor quando se diz por imagens, escapando às conceituações totalizantes, podendo, no exercício do retorno da poesia, refazer-se continuamente, como o exercício contínuo de tecer-se nos versos que Hilda Hilst instaura em sua obra. Pode-se dizer, então, que por sua dupla e concomitante inscrição, a de um sujeito e a de uma linguagem, por reiterar duplamente o registro de uma individualidade a partir de si própria, o autorretrato lírico seria, entre as expressões literárias, a forma que possibilitaria a construção de um texto com maior carga de subjetividade.

Na poesia de Hilda Hilst, o uso dessa forma de escrita de si relaciona-se à construção de uma imagem que, acima de tudo, submete-se à bela tirania do discurso poético, que é a essência de sua formulação, sendo, por outro lado, o fator decisivo para que essa construção simbólica do eu apareça embaralhada, sujeita a variações e a dissoluções. São autorretratos que implicam que, neste caso, o sujeito só se institua a partir da linguagem poética, sendo, por isso, um artifício que pode ser a qualquer momento ressignificado.

Em sua lírica, Hilst utiliza essa forma de escrita de si a partir de diversas variações que lhe são permitidas, como a prece, a confidência, o testamento, ou outros nos quais o eu apresenta uma imagem de si mesmo a partir de seu próprio olhar.

Em sua longa obra, a autora experimenta diferentes formas que o autorretrato pode assumir na poesia lírica. Em Cantares, e especialmente "Cantares de perda e predileção", podemos verificar es- 
pelhos, desenhos, pinturas, imagens. Os autorretratos vão tomando formas diversas, mas com interessantes configurações que emanam de suas compleições. As próprias "especificidades" dessa forma de escrita de si aponta para as variações, uma vez que o autorretrato apresenta-se como variável e anticanônico, pois, como afirma Clara Rocha, "este gênero não possui qualquer horizonte de expectativa, porque não obedece a nenhum modelo: cada autor de autorretrato (re)começa o trabalho de escrita como se este fosse único no seu gênero" (1992, p.42).

De maneira geral, pode-se dizer que os autorretratos disseminados na obra de Hilst são contaminados pela dissolução que a linguagem poética propõe das concepções seguras. Assim, também o sujeito que é evocado nesses retratos é difícil de se apreender, e em suas fulgurações se mostra sempre escorregadio, múltiplo, "simultâneo", ou seja, impossível de se determinar de maneira unívoca:

E me fiz máscara, mulher e conjetura. (Hilst, 2004, p.33)

Sou isto: um alguém-nada que te busca. (Hilst, 2004, p.35)

A minha Casa, Dionísio, te lamenta

E manda que eu te pergunte assim de frente:

À uma mulher que canta ensolarada

E que é sonora, múltipla, argonauta. (Hilst, 2001, p.61)

Porque te amo, Dionísio,

É que me faço assim tão simultânea

Madura, adolescente (Hilst, 2001, p.62)

Nessas fulgurações, o eu hilstiano se retrata a partir de sua constante espetacularização - para se fazer visível para o outro - e do seu confronto com o tempo, elemento inalienável que a tudo captura e impede que uma imagem se consolide. Esses dois elementos de movência, o outro e o tempo, trarão aos autorretratos hilstianos um 
caráter de experimentação e fugacidade. No entanto, há outro tipo de autorretrato presente nessa autora, o autorretrato do retrato, ou seja, o eu fazendo convergir para si a imagem de poeta, e a figura que surge é a de um eu que só se realiza na poesia.

De maneira bastante móvel, então, os autorretratos de Hilst, em vez de fixar uma imagem, desdobram-na, apresentando uma identidade fugidia, de eternos retornos, que se inscreve recorrentemente na poesia para poder, de alguma forma, dar a conhecer uma identidade incognoscível.

\section{2. "Um espelho molhado de umas águas"}

"Um espelho molhado de umas águas" (Hilst, 2002, p.55). Assim os autorretratos de Hilda Hilst se desenrolam, carregando embriões de imagens que se dissolvem nas várias faces que surgem, sem que nenhuma de fato se fixe. Isso significa que Hilst tem plena ciência de que se retratar pela palavra, e, mais especificamente, pela imagem, implica desdobrar-se, fazer-se outrem, tornar-se várias, e, por conseguinte, nenhuma.

O poema XXII de "Cantares de perda e predileção" confirma essa dissolução no múltiplo da imagem, apresentando-se não como uma identidade reconhecida e reconhecível, mas como possibilidades e desdobramentos:

Talvez eu seja

O sonho de mim mesma.

Criatura-ninguém

Espelhismo de outra

Tão em sigilo e extrema

Tão sem medida

Densa e clandestina

Que a bem da vida

A carne se fez sombra. 
Talvez eu seja tu mesmo

Tua soberba e afronta.

E o retrato

De muitas inalcançáveis

Coisas mortas.

Talvez não seja.

E ínfima, tangente

Aspire indefinida

Um infinito de sonhos

E de vidas.

(Hilst, 2002, p.82)

Esse poema, realizado a partir de um espelhismo verbal, em que o subjuntivo coloca em evidência a concepção do eu através de possibilidades, demonstra que os autorretratos de Hilst pincelam muito mais experimentações do que identidades propriamente ditas, em um movimento escorregadio que o vocabulário do poema vai evocar: "clandestina", "sombra", "retrato", "tangente", "indefinida", "infinitos" e, principalmente, a palavra "sonho", que aparece duas vezes, no início do poema - e que é ampliada, não somente pela desinência no plural, no penúltimo verso, mas por vir acompanhada do substantivo "infinito". Da mesma forma, em uma formação paralela, a palavra "vida" também se repete, no final, em sua forma plural, encerrando o poema com esse duelo entre a realidade e a invenção.

A tensão "sonho/vida", que marca o início e o fim do poema, apresenta desde o princípio o conflito realidade-criação, na primeira estrofe vinculado a um eu espelhado no pronome oblíquo "mim" e reiterado pelo advérbio "mesmo", e no final do poema aproximando os dois termos em função das infindáveis possibilidades: "um infinito de sonhos/ e de vidas". Assim, já em seu momento inicial, o poema abre para uma das questões teóricas do autorretrato lírico, a irresoluta fricção entre realidade e invenção em toda 
concepção poética. Aqui, sendo esse um texto que de imediato se propõe duplo, uma vez que se coloca como um espelho, no qual o tu e o eu se confrontam, as possibilidades espectrais se tornam inumeráveis.

O espelhismo que marca gramaticalmente o início do poema, e que implica identidade e diferença, contamina os outros versos, por meio de oposições ("Criatura-ninguém/Espelhismo de outra", eu/ tu, "Talvez eu seja" /"talvez não seja"), repetições ("mim mesma”, tão...tão), e aproximações sonoras (aliterações, assonâncias, rimas toantes). A sequência "ínfima"/, "indefinida", "infinita" merece um destaque, pois apresenta três caracterizações que, marcadas pela sonoridade, "dançam" pela estrofe e explodem na palavra "vida", pelas assonâncias do "i" e "a" e pela repetição das oclusivas $(\mathrm{t} / \mathrm{d})$ e labiodentais (v/f).

Assim, desde a primeira estrofe, esse gesto especular é marcado pela constituição icônica, uma vez que o quarto verso ("Espelhismo de outra"), ou seja, a exata metade desse grupo de sete versos, é justamente aquele que se refere pela primeira vez ao espelho, trazendo à cena a "outra", esta sim descrita nos três versos seguintes: "tão em sigilo e extrema/tão sem medida/densa e clandestina". O ato de se autorretratar aqui se localiza neste movimento de se olhar no espelho e se reconhecer somente a partir da imagem criada que se apresenta para si. Afinal, autorretratos líricos não remetem à realidade, e, como Lejeune diz, ninguém se parece consigo mesmo:

Ninguém se parece consigo. Nada em mim implica necessariamente a cor dos meus olhos, o tamanho do meu nariz, nem o resto. Habituei-me a meu rosto, mas esse hábito não resiste à surpresa de uma passagem diante de um espelho, nem a uma autocontemplação um pouco mais demorada. Olhos nos olhos, dissolvo-me. Com o pincel na mão, reconstruo-me, preencho as brechas, envolvo-me, circunscrevo-me, restauro-me, coloco-me "em bom estado", em cena, para outrem, como outrem. Mas essa imagem não é muito consistente, falta aquela centelha de espanto, um brilho no olhar. (Lejeune, 2008, p.245) 
Em Hilda Hilst, essa "estranheza" de si mesma já havia aparecido antes, como é possível verificar no poema 4 das "Heroicas", na Ode fragmentária:

Sendo quem sou, em nada me pareço.

Desloco-me no mundo, ando a passos

E tenho gestos e olhos convenientes.

Sendo quem sou

Não seria melhor ser diferente

E ter olhos a mais, visíveis, úmidos

Ser um pouco de anjo e de duende?

(Hilst, 1980, p.216).

A segunda estrofe, de dois versos, tem um caráter de síntese, reiterando o espelhismo ao se descrever como sombra. Essa síntese, que lembra o discurso religioso, o versículo 14 do evangelho de João, "E o verbo se fez carne", aqui deixa o âmbito sagrado para clamar à carne, que se torna "sombra": "E a carne se fez sombra". Nesse confronto, pode-se dizer que a postulação de o divino ter-se tornado humano é retomada a partir de uma subversão: o verbo-carne se faz sombra, ou seja, tanto o ser quanto o seu lastro divino, e em Hilst a poesia sempre se dá nas emergências do sagrado, torna-se desdobramento, duplicidade e também esvaecimento.

A estrofe seguinte, de cinco versos, que pode ser lida como similar à primeira - caso se considere que dois versos foram destacados na anterior, o que implicaria uma estrofe também de sete versos dá-se no âmbito do tu, o outro lado do espelho. O outro surge para complementar a tentativa de se realizar uma acepção - mesmo que fugidia - do eu, e é marcado não somente pela presença do pronome em segunda pessoa, mas pelo deslocamento da primeira pessoa para a terceira, também indício do movimento de "outrar-se" para se retratar. O retrato pressupõe esse elemento exterior, que é o retratista, sendo, então, sempre uma expressão do eu por um outro, mesmo que o outro seja o eu. 
Em Hilst, a presença do outro marca não somente a espetacularização típica da fotografia, mas também remete às questões da identidade feminina que formulam o canto dessa poeta. Em uma parte considerável de sua lírica, os autorretratos tornam-se peças retóricas para convencer um interlocutor amoroso e o eu lírico se apresenta para que seu amado o aprecie e retribua-lhe o amor.

Entre as mais belas líricas amorosas femininas da literatura brasileira, esses poemas envolvem um eu se apresentando para seu objeto de amor, e, como na maior parte dos poemas dessa estirpe, a confidência se torna o tom que norteia a composição poética. Falar do amor é confidenciar, é dizer o inaudito, é tornar público aquilo que é mais privado e íntimo. Em Hilst, o despojar-se traz um tom que vai levar a limites de expressão que a poesia de autoria feminina ainda não havia atingido.

Hilda Hilst delineia os autorretratos de sua persona amorosa a partir de uma transfiguração do eu no tu: "Buscando-me a mim, minha tua cara" (Hilst, 2002, p.33). Aquele a que alguém pertence é "um outro alguém sem cara" (Idem). Amar é indefinir-se. O próprio amor se estabelece nessa zona da indeterminação. Na primeira parte de Cantares, "Cantares do sem nome e de partidas", o amor é tido como o "sem nome", "ESSE", terminando por ser chamado de “isso". E aquele que ama, o "pertencente”, não se tem:

Pertencente é não ter rosto. É ser amante

De um Outro que nem nome tem. Não Deus nem Satã.

Não tem ilharga ou osso. Fende sem ofender.

É vida e ferida ao mesmo tempo, "ESSE"

Que bem me sabe inteira pertencida”.

(Hilst, 2002, p.24)

Sem rosto, somente pelo outro o eu se desenha nesses poemas de lamentos e súplicas. O canto de voz feminina, reminiscência das antigas cantigas medievais, revigora-se em Hilda Hilst pela força de uma palavra que leva aos limites os contrapontos entre os polos que 
mediam o amor, o eu e o tu, o sagrado e o humano, a dor e o prazer. Pertencente, sem ter-se, o eu lírico não se possibilita definir, cabendo ao outro dizê-lo a partir de uma visão externa, que traz a imagem de alguém solitário e partido. Nesse jogo de submissão e subversões, o eu refaz a cada poema sua trajetória de ser do outro: "E do tormento/De só por ele me saber estar sendo” (Hilst, 2002, p.17).

Esse deslizar da identidade para um rosto que perde a leveza e assume uma atitude mais grave, um rosto-pensamento ("Intocado meu rosto-pensamento") (Hilst, 2001, p.25), vai se constituir a partir das dilacerações resultantes da experiência amorosa, como se pode verificar no poema $\mathrm{V}$ :

Ah, se eu soubesse quem sou.

Se outro fosse o meu rosto.

Se minha vida-magia

Fosse a vida que seria

Vida melhor noutro rosto.

Ah como eu queria cantar

De novo, como se nunca tivesse

De parar. Como se o sopro

Só soubesse de si mesmo

Através da tua boca

Como se a vida só entendesse

$\mathrm{O}$ viver

Morando no teu corpo, e a morte

Só em mim se fizesse morrer.

(Hilst, 2001, p.35)

Essa identidade presumida, que confronta aquela supostamente "verdadeira", vincula-se à ideia de que por si só o eu não alcança um conhecimento de sua identidade, mas, ao se desdobrar em imagem, o sujeito que se autorretrata estabelece um pacto com o outro, pois a imagem é sempre exteriorização, e, portanto, é desse olhar 
alheio, de si mesmo ou da perspectiva do outro, que sua identidade é tecida. ${ }^{3}$

Nessa tentativa de se tornar visível ao outro e com o outro, outros tipos de autodescrições se estabelecem, como o quadro e o desenho. No poema IV Cantares de perda e predileção, uma cena se apresenta com os dois amantes fixados um ao lado do outro:

Lobos

Lerdos leopardos

Cadelas

Ternuras velhas

Nós, lado a lado

Num sumidouro de linhas

E ponteiros de pedra.

Enrodilhados

Escuros

Famintos de nossas sombras

Nas aldeias antigas

Lobo

Leopardo-cadela

Ternuras velhas

3 A representação não incide sobre um percurso vital, mas sobre uma personagem que se olha no espelho e que se apresenta como espetáculo, na sua aparência e na sua profundidade. Ainda aqui, a metáfora pictórica que dá o nome ao autorretrato é fecunda: tal como o pintor necessita do espelho para recriar sua figura, também aquele que se pinta na escrita se mira no espelho de Narciso. E devolve-nos uma imagem que, apesar de ser símile, presentifica o próprio eu ("Eis Bocage...", lê-se no final do conhecido autorretrato do poeta setecentista)" (Rocha, 1992, p.41). 
Tu e eu desenhados

Treliças e telas

Nas tintas da conquista.

(Hilst, 2002, p.36)

Nos desenhos, as linhas são sutis, espaçadas, em pinceladas fugazes, que estrofes e versos rápidos reproduzem. O jogo amoroso, metaforizado pelo embate entre lobos-leopardos e cadelas, são mediados pelas "ternuras velhas", a primitiva história da conquista, que se pinta no poema em linhas esvaecentes. Linhas que metaforizam a escrita poética, realizada em Hilst por uma proposta de movência e tangência.

Da mesma forma, o eu também invade o espaço da gravura do tu - à força, pois ela não é convidada:

Como se desenhados

$\mathrm{Tu}$

E o de dentro da casa.

Entro

Como se entrasse

No papel adentro.

E sem ser vista

Rasgo

Alguns véus e fibras

Sem ser amada

Pertenço.

Que sobreviva

O fino traço de tua presença.

Aroma. Altura.

E lacerada eu mesma

Que jamais se perceba

Umas gotas de sangue na gravura.

(Hilst, 2002, p.47) 
No poema, a pintura é o modo de apreender o que não lhe pertence, já que ela a ele pertence. Não seria exatamente esta a função do autorretrato, ou autodesenho, ou autopintura, ou seja, apreender o que escapa, exatamente as configurações de um eu? Assim, o outro desfigura mas compactua, e nesse jogo de conflito e tensões, os autorretratos vão mostrando e escondendo, delineando e escondendo.

O outro também vai aparecer em outros parâmetros, como um eu que se fixou no passado e que hoje é memória, impossível de ser alcançado, perdido no tempo que se esvaiu. Todo autorretrato traz um permanente diálogo com o tempo, uma vez que supostamente "fixa” um eu que já não está mais lá, que o tempo se encarregou de levar. Flash de um tempo passado, então, é sempre da memória que se trata o ato de fotografar, e é esta a perspectiva que o poema II de Cantares de perda e predileção apresenta:

Que dor desses calendários

Sumidiços, fatos, datas

O tempo envolto em visgo

Minha cara buscando

Teu rosto reversivo.

Que dor no branco e negro

Desses negativos

Lisura congelada do papel

Fatos roídos

E teus dedos buscando

A carnação da vida.

Que dor de abraços

Que dor de transparência

E gestos nulos

Derretidos retratos

Fotos fitas

Que rolo sinistroso

Nas gavetas. 
Que gosto esse do Tempo

De estancar o jorro de umas vidas.

(Hilst, 2002, p.34)

O poema compõe-se de expressões que ressaltam a angústia do tempo móvel em um sujeito que teve sua imagem congelada na expressão artística. A anáfora "Que dor", repetida quatro vezes nas cinco estrofes, reitera a efemeridade da vida, que anula os gestos e torna o ato de ver uma fotografia não um momento de prazer, mas um exercício de perda. As referências ao retrato se cercam de palavras que marcam essa vivência de luto: os "negativos" estão congelados no papel, os retratos são "derretidos", os rolos "sinistrosos" na gaveta. Ao final, o Tempo, em maiúscula, estanca o jorro da vida.

Em Hilst, o ato de se autorretratar, além de perpetuar a imagem de um eu que não se fixa, também se liga à consciência de que esse eu é "sumidiço", adjetivo que ela repete em alguns poemas e que marca a dor da passagem do tempo. Os autorretratos na poesia de Hilda Hilst não fixam uma imagem: ao mesmo tempo que a delineiam, a desmancham. Dessa forma, mesmo dizendo-se incapaz de se retratar, a escrita é o álibi para que vai se contando e se refazendo o tempo todo. Nesse jogo, a colcha que Penélope tece e destece o tempo todo com os fios da palavra poética desenha um rosto volátil e inapreensível.

Assim, a lição desses exercícios hilstianos de "dizer o eu" é a de que a relação sujeito/linguagem poética, inextricável, ambígua, mas una, reorganiza as formas de escrita do eu, e sugere que tudo é linguagem e toda linguagem é construção simbólica, sendo, portanto, submetida ao eterno retorno do mesmo, sob novas concepções.

\section{Referências bibliográficas}

ABREU, L. P. O auto-retrato como espetáculo e controle na contemporaneidade. Rio de Janeiro: UFRJ/ECO, 2005.

ARFUCH, L. O espaço biográfico: dilemas da subjetividade contemporânea. Rio de Janeiro: EdUERJ, 2010. 
BENN, G. Problemas da lírica. Trad. Fábio Weintraub. Rio de Janeiro, Cadernos Rioarte, ano I, n.3, p.4-11, 1985. Conferência proferida em 1951.

COMBE, D. A referência desdobrada. Revista USP, São Paulo, n.84, p.112-28, dez./fev. 2009-2010.

ELIOT, T.S. Tradição e talento individual. In: Ensaios. Trad. Ivan Junqueira. São Paulo: Art, 1989, p.37-48.

FRIEDRICH, H. Estrutura da lírica moderna (da metade do século XIX a meados do século XX). São Paulo: Duas Cidades, 1991.

GOETHE. Memórias: poesia e verdade. 2.ed. Trad. Leonel Vallandro.

Brasília: Editora da Universidade Federal de Brasília; Hucitec, 1986.

HEGEL. Cursos de Estética. Trad. Marco Aurélio Werle, Oliver Tolle.

São Paulo: Editora da Universidade de São Paulo, 2004. v.IV. (Clássicos; 26).

HILST, H. Cantares. São Paulo: Globo, 2002. 134p. (Obras reunidas de Hilda Hilst). . Do desejo. São Paulo: Globo, 2004.

- Júbilo, memória, noviciado da paixão. Org. Alcir Pécora. São Paulo: Globo, 2001. Poesia: 1959-1979. São Paulo: Quíron; Brasília: INL, 1980.

LEJEUNE, P. O pacto autobiográfico: de Rousseau à internet. Trad. Jovita Maria Gerheim Noronha, Maria Inês Coimbra Guedes. Belo Horizonte: Editora UFMG, 2008.

ROCHA, C. Máscaras de Narciso. Coimbra: Almedina, 1992. 


\section{Os ofícios do sacro em Poemas MALDITOS, GOZOSOS E DEVOTOS DE HILDA HILST}

Higor Sampaio

Em Poemas malditos, gozosos e devotos, originalmente publicado em 1984, Hilda Hilst decidiu enfrentar deliberadamente o que sempre assombrou seu universo poético: uma certa "ideia de Deus". Como transfiguração de um real, os acordes deste conjunto poético encenam o erotismo na relação entre o homem e a divindade enquanto experiência subjetiva, significativamente solitária, em que o desejo e a ausência se confinam em traços e silêncios. Na ânsia por essa "ideia de Deus", Poemas malditos, gozosos e devotos esbarra em uma poética da desordem e do excesso, em que a carne, o sangue, o martírio, a anulação, a súplica, a devoção e o desejo aí confinam: "É de uma Ideia de Deus que te falo./ Pesa mais se ausente/ Pesa menos se te toma// Ainda que descontente/ Te vejas pensando sempre..." (Hilst, 2005, p.55). No universo poético da poeta paulista, o Sagrado, enquanto força que limita a subjetividade, convive lado a lado com a experiência mundana e, sobretudo, erótica, atestado pelo sensualismo desconcertante que perpassa esse discurso, o qual agrega ao espaço do poema uma linguagem que, por vezes, beira o chulo e o vulgar.

Assim como a morte, a duração e a ânsia pelo sagrado, o erotismo faz parte da gama de experiências do homem, sendo talvez aquilo que ofereça uma significação profunda à essência dessa con- 
dição, e até talvez à essência da escrita literária, o que me recorda a seguinte passagem da portuguesa Ana Hatherly: "a escrita é uma fala muda, uma forma de materialização do imaginário” (Hatherly, 2005, p.107). Os discursos sobre o erótico (Bataille, 1987; Paz, 1995, 1999) concordam em afirmar que o erotismo é propriamente uma invenção do homem e se distingue do sexo porque, em essência, não visa à reprodução, finalidade primordial da atividade sexual, sendo o prazer um fim buscado em si mesmo. No jogo do erotismo, a imagem de um Outro ${ }^{1}$ é sempre presente na condição de assombro e fascinação, e o desejo e a fantasia são as molas propulsoras dessa experiência. Jogo de ausência e presença, de aproximação e distanciamento, não há erotismo sem a imagem, muitas vezes fantasmagórica, daquele que está fora e além do eu, daquele que o difere e o anima. O erotismo encerra em si o apetite de completude.

Ainda que nesse aspecto o pensamento de Bataille concorde com o de Paz ao também afirmar que o erotismo não se preocupa com nada mais que com o prazer, ou seja, a reprodução não é a meta do jogo entre corpos, a reprodução "não constitui menos a chave do erotismo" (Bataille, 1987, p.12), visto que engendra "seres descontínuos", diversos uns dos outros, diferença que, para o pensador francês, funda o erótico. O erotismo, sendo um dos aspectos daquilo que pode ser denominado "vida interior do homem", a qual vai da "santa ao sensual", faz o sujeito enquanto desejo procurar fora de si o seu objeto. E será justamente essa descontinuidade entre os seres ou esse "abismo" que separa as singularidades a propulsão do erótico, pois, na ótica batailleana, o ser engendrado pela reprodução tem a nostalgia da "continuidade perdida", a qual comandará todas as formas do erotismo: " somos seres descontínuos, indivíduos que

1 Sendo o erotismo um ato interpessoal, entendo aqui o Outro como o objeto de desejo, ainda que imaginário, do Eu, Presença opressora que mobiliza a fantasia da subjetividade na experiência do erotismo, pois como bem afirma Paz (1999, p.26), “sem o 'outro' não existe erotismo porque não existe espelho”.

2 Em $O$ erotismo, Bataille distingue três formas de erotismo, a saber: o "erotismo do coração", o "erotismo dos corpos" e o "erotismo sagrado", sendo que a última forma encerra em si as duas primeiras, pois, para ele, "todo erotismo é 
morrem isoladamente numa aventura inteligível, mas temos a nostalgia da continuidade perdida" (Bataille, 1987, p.15).

Octavio Paz (1982) também comunga com a hipótese de que o homem é somente Desejo. Para ele, todas as empresas humanas têm por movimento a nostalgia de uma unidade perdida, de um estágio inicial do qual os homens foram separados. Para o homo religious, o mundo profano da Queda é o lugar do ser que é pouco, desejante; e a plenitude procurada está no mundo sagrado, portanto pleno, lugar daquilo que é tudo. É esta a causa dos impulsos humanos para o Outro, e a sensação de completude, ou Unidade, aparece somente nas experiências que encenam a comunhão, haja vista o erotismo, o amor, a religião e a arte.

Mas também o erotismo com seu anseio de unidade é sempre desestabilizador, porque perturba um mundo fundado na descontinuidade. Segundo Bataille, a violência ${ }^{3}$ é o que anima o erotismo, o qual pretende estabelecer a continuidade num estado de descontinuidade próprio do ser isolado: “o que está em jogo no erotismo é sempre uma dissolução das formas constituídas. Digo: a dissolução dessas formas de vida social, regular, que fundam a

sagrado", na medida em que tenta estabelecer uma continuidade ou unidade no estado de isolamento em que cada ser, na existência humana, se encontra. No universo poético dos Poemas malditos, gozosos e devotos, essas formas não são delineadas, visto que pensar aqui sobre uma "ideia de Deus" dá margens à ambiguidade do erótico, o qual passeia livremente entre as esferas do "alto" e do "baixo", do humano e do sagrado.

3 Nem toda forma de erotismo é violenta, se compararmos o pensamento de Georges Bataille e Octavio Paz, por exemplo. Entretanto, o erotismo em Hilda Hilst é sim "violento", batailleano, visto que sempre acaba por encenar um ato sacrificial: aliando prazer e sofrimento. O riso irônico hilstiano reside nisto: em revelar o absurdo do martírio/sacrifício nas formas constituídas de prazer erótico. Nesse sentido, os prazeres ditos bestiais pela civilização são também invenções humanas, prazer subjugado e submetido à técnica e à imaginação de uma mente civilizada e racional. Ou, nas palavras de Paz (1999, p. 56-57): "todos os atos eróticos são desvarios, desarranjos; nenhuma lei, material ou moral, os determina. São acidentes, produtos fortuitos de combinações naturais. Sua própria diversidade delata a falta de significação moral. Não podemos condenar a uns e aprovar a outros...". 
ordem descontínua das individualidades definidas que nós somos" (Bataille, 1987, p.18). Por isso, Bataille afirma que o erotismo não pode ser estudado fora da história do trabalho nem da religião. $\mathrm{O}$ erotismo humano difere da sexualidade animal porque, primeiro, a escolha do objeto de desejo depende do gosto pessoal; segundo, porque coloca em jogo a vida interior e o ser, experiência que, na maioria das vezes, gera sofrimento, visto que a angústia em se saber descontínuo pode, ainda que por pouco tempo, ser superada na continuidade percebida no objeto de desejo.

O erotismo não pode ser desvinculado do mundo do trabalho porque é sua contraparte. Ao erigir um mundo do trabalho, o homem se distingue do animal e, para manter a ordem, exigem-se uma série de "interditos", restrições que incidem sobre a atividade sexual e a atitude para com os mortos, assim como para a predisposição humana ao assassínio. Nesse sentido, a experiência do trabalho fundou o mundo racional do homem e o distanciou dos animais, exigindo do ser um comedimento, uma "conduta sensata", um modo de ser que refreasse os sentimentos intrínsecos ao mundo interior, tais como o impulso sexual, a festa ou o jogo, por exemplo. Entretanto, a violência, de alguma forma, excede o interdito, pois "não há interdito que não possa ser transgredido" (Bataille, 1987, p.59). Os interditos eliminam da experiência tudo aquilo que foge ao domínio da razão, a constar a violência, na qual se inclui o impulso sexual. Já o mecanismo da transgressão deflagra a violência e, nessa lógica, o sentimento de pavor, próprio do interdito, convive em paralelo com o fascínio, capaz de instaurar no ser a transgressão. Pode-se aqui, então, aproximar o sentimento religioso do erótico, pois ambos associam o desejo e o medo, o prazer intenso e a angústia. Tanto no religioso quanto no erótico, o interdito molda a razão e rejeita a violência, e as transgressões as liberam:

[...] a verdade dos interditos é a chave de nossa atitude humana. Devemos, podemos saber exatamente que os interditos não são impostos de fora. Isto nos aparece na angústia, no momento em que transgredimos o interdito, sobretudo no momento suspenso 
quando ele ainda atua e que, mesmo assim, cedemos ao impulso a que ele se opunha. Se observamos o interdito, se a ele nos submetemos, não temos mais consciência dele. Mas sentimos no momento da transgressão a angústia sem a qual o interdito não existiria: é a experiência do pecado. (Bataille, 1987, p.35-6)

Daí nasce uma nova perspectiva sobre o Sagrado, que passa a ser visto como objeto de uma interdição. Interdito que, ao modo dos demais, atemoriza mas também fascina, pois, se os homens temem seus deuses, eles também os veneram, e a transgressão conduz à devoção. $\mathrm{O}$ mundo sagrado, portanto, tal como o assassínio, a guerra, a festa e o erotismo, pertence exclusivamente ao mundo dos excessos que a razão se esforça para conter. $\mathrm{O}$ impulso do sujeito em direção à divindade é mesmo em direção ao objeto de desejo sensual: a nostalgia da continuidade, e é a violência que colocará, portanto, um fim à descontinuidade da condição humana. Por isso, Bataille afirma que o erotismo é essencialmente sagrado, uma vez que aponta para um estado - infinito e ilimitado - que está além da ordem estabelecida e do isolamento do ser.

Essa reflexão se torna mais clara quando pensamos, por exemplo, no sacrifício, ato religioso por excelência, o qual promove em um rito determinado uma abertura para a manifestação da realidade sagrada. De acordo com Hubert e Mauss (2005), o sacrifício é uma prática adotada por quase a totalidade das religiões que buscam a "comunhão" com os deuses. No ofício do sacro que é o sacrifício há concretização do sentimento original do vocábulo "religião" do latim religo, ou seja, religar-se. A hipótese de Hubert e Mauss é de que o sacrifício nasce de uma necessidade profunda dos homens que se viram, em determinado momento, distantes dos seus deuses, sendo, portanto, uma "dádiva" que esses homens dirigem a "seres sobrenaturais aos quais lhes convém se ligar" (Hubert e Mauss, 2005, p.8). Em sua unidade, o sistema sacrificial consiste numa "consagração" de algo - homem, animal ou objeto - do domínio comum e ordinário ao domínio sagrado. No entanto, a coisa 
oferecida não é uma simples oferenda a exemplo dos ex-votos, ${ }^{4}$ mas uma "oblação", pois em todo sacrifício a coisa oferecida aos deuses deve ser destruída; por isso, o rito sacrificial guarda em si o sentido da destruição.

Mas se todo sacrifício é, de fato, uma oblação, há oblações de espécies diferentes. Às vezes o objeto consagrado é simplesmente apresentado como um ex-voto: a consagração pode afetá-lo no serviço do deus mas não altera sua natureza pelo simples fato de fazê-lo passar para o domínio do religioso - caso das primícias apenas trazidas ao templo e que ali permaneciam intactas e pertencentes aos sacerdotes. Outras vezes, ao contrário, a consagração destrói o objeto apresentado: no caso de um animal apresentado ao altar, a finalidade buscada só é atingida quando ele for degolado, esquartejado ou consumido pelo fogo - em suma, quando foi sacrificado. $\mathrm{O}$ objeto assim destruído é a vítima. É evidentemente às oblações desse tipo que deve ser reservada a denominação de sacrifício. (Hubert e Mauss, 2005, p.17-8)

A comunicação entre os dois mundos acontece através do rito cerimônia que consagra a passagem do profano ao sagrado -, no qual um "sacrificante" (aquele sobre o qual recairão as bênçãos do sacrifício), um "sacrificador" (aquele que se incumbirá pela destruição da dádiva) e a "vítima” marcam presença. É por meio do sacrifício que o homem se aproxima dos deuses e, a partir do contato, não somente a vítima, mas também o fiel é alçado ao plano da graça, deixando por ora um estado de pecado ou erro que o teria levado a alimentar a divindade. A intenção originária do sacrifício é a purificação de algum malefício, é a ascensão a um estado de dádiva ou,

4 "Ex-votos" são objetos colocados em templos religiosos para pagamento de uma promessa ou em agradecimento por uma graça alcançada. Se o fiel for curado, por exemplo, de uma dor de cabeça crônica, confecciona-se uma cabeça de cera para que por fim seja entregue ao templo e seja índice da graça alcançada por intermédio de uma força sobrenatural. 
até mesmo, segundo Hubert e Mauss (2005, p.68), a vontade de adquirir uma "força divina". O sacrifício deve oferecer àqueles que participam de seu drama a regeneração, o renascimento para uma nova vida e um novo começo, visto que através da destruição há o retorno da "vida sadia" das coisas. Nesse drama sangrento, a personagem mais proeminente, portanto, é a vítima. É por meio dela, ou melhor, de seu aniquilamento, que os deuses se aproximam dos homens, impregnando o mundo profano das coisas sagradas. Sendo alimento, a vítima estabelece, enfim, o tão sonhado elo entre o crente e a divindade, possibilitando ao primeiro a continuidade desejada da qual foi separado.

A vítima experimenta a ascensão e a queda, o salto e o abismo, movimento que parte do profano ao mais sagrado, deflagrado pela consagração da coisa ou ente que será, posteriormente, destruído, o qual suscita aos participantes do rito a impregnação do sacro até o momento em que definitivamente o Sagrado se "mostrará" na imolação. "A série de estados pelos quais passa a vítima poderia então ser figurada por uma curva que se eleva a um grau máximo de religiosidade, em que permanece só um instante, e daí torna a descer progressivamente" (Hubert e Mauss, 2005, p.51). No ofício do sacro, "alto" e "baixo" não podem nunca ser separados; devem ser vistos como estados intercambiáveis de um mesmo processo. Nessa mecânica, a vítima é consagrada e divinizada a partir de um ato que se fundamenta na destruição e, segundo Bataille (1987), suspendendo, enfim, um dos interditos que fundam a civilização: o assassínio. Talvez tenha sido por isso que, em certo momento, com o desenvolvimento da civilização, os homens substituíram suas vítimas humanas por animais: porque imolar seus pares "pareceu horrível”. Ao suspender o interdito do assassínio, há uma brusca ruptura da descontinuidade do ser; a vítima é entregue à continuidade do Sagrado, sendo este o elemento revelado a partir do derramamento de sangue. A transgressão exigida pelo ato religioso do sacrifício eleva os participantes do rito além do mundo ordinário e ordenado da vida comum, colocando-os, por um momento, em contato com as forças sobrenaturais, próprias dos deuses, e 
abrindo-lhes o mundo dos "excessos da violência", no qual a morte, a reprodução e o erotismo figuram:

[... ] uma violência tão divinamente violenta eleva a vítima acima de um mundo vulgar, onde os homens vivem sua vida calculada. Em relação a essa vida calculada, a morte e a violência excedem, não podendo se deter no respeito e na lei que ordena socialmente a vida humana. A morte na consciência ingênua não pode derivar senão de uma ofensa, de um desrespeito. Ainda uma vez a morte derruba violentamente a ordem legal. (Bataille, 1987, p.77)

Como o sacrifício, o movimento erótico desagrega os seres. Neste jogo, a princípio, a parte masculina desempenha um papel ativo, enquanto a parte feminina, passivo. Encarnando o papel da vítima, a feminina é justamente a parte dissolvida, e a masculina desempenha a função do grande sacrificador. A violência aqui é deflagrada nos órgãos sexuais e a mulher, nas mãos do seu amante, não se distancia muito da vítima nas mãos do sacrificador; ao perder o pudor e se integrar ao ofício sexual, a parte passiva é tomada pela violência que a leva à ultrapassagem da ordem. Nesse movimento entrecorpos há uma continuidade "momentânea" dada pelo orgasmo; contudo, "depois da crise, a descontinuidade de cada um dos dois seres está intacta” (Bataille, 1987, p.96). É a partir dessa lógica que Bataille insere o erotismo na ordem do sagrado, uma vez que o contato com o Outro gera a desordem, ainda que momentaneamente, própria da continuidade do mundo dos deuses. A violação do ser dos amantes vizinha com a morte e com o assassínio, e a euforia provocada pelo vislumbre do contínuo é tamanha que, em algumas formas de erotismo, como a paixão, por exemplo, o gozo que acompanha a desordem não se livra do vínculo com o sofrimento, visto que é "carência e desejo de posse daquilo que desejamos e não temos; por sua vez, é felicidade porque é posse, embora instantânea e sempre precária” (Paz, 1995, p.154). A unidade revelada no erotismo é da mesma natureza daquela revelada pelo Sagrado, reagindo, desse modo, à precariedade da nossa condição, 
a de seres mortais, perecíveis e descontínuos. Na lógica batailleana, esta reação somente ocorre quando há o "horror" do derramamento do sangue, significante da desordem e do excesso.

O que o ato de amor e o sacrifício revelam é a carne. O sacrifício substitui pela convulsão cega dos órgãos a vida ordenada do animal. O mesmo acontece com a convulsão erótica: ela libera órgãos pletóricos num jogo cego que suplanta a vontade ponderada dos amantes. A essa vontade ponderada sucedem os movimentos animais desses órgãos cheios de sangue. Uma violência que escapa ao controle da razão anima esses órgãos, distendo-os até o limite máximo e, de repente, é a felicidade que se atinge ao ultrapassar essa desordem. [...] A carne é em nós esse excesso que se opõe à lei da decência. (Bataille, 1987, p.86)

O erótico assombra porque nele há derrame de sangue, visão da carne, e a pretensa racionalidade erigida pela civilização se desintegra na transrazão e no retorno à bestialidade. Sendo transgressão de um interdito, harmoniza novamente o homem com sua animalidade contida e, desse modo, provoca um esforço nos mantenedores da ordem para controlar seus impulsos primeiros, tão distantes da razão "edificante". Nota-se que, frequentemente, casamento e erotismo não são associados, porque ainda se pensa que o erotismo conduz o ser a práticas sexuais que são consideradas vergonhosas; e, realmente, o erotismo exige a perda do pudor e o martírio da carne para instaurar sua desordem tão benéfica. Em concordância com Bataille, Paz também afirma que o erotismo ameaça os alicerces da razão pelos quais a sociedade foi erigida, já que, se o sexo é criação, é também destruição: "o sexo é subversivo: ignora as classes e as hierarquias, as artes e as ciências, o dia e a noite: dorme e somente acorda para fornicar e voltar a dormir" (Paz, 1995, p.14). A sociedade, enfim, com a intenção de controlar esses "excessos", instituiu uma série de tabus e interdições que regulam e controlam o instinto sexual e seu apetite de destruição. Daí nasce a ambiguidade do erotismo: criação e destruição, repressão e libertinagem, 
Eros e Tânatos, "sublimação e perversão", dualidades encarnadas nas figuras do religioso solitário e do libertino sensual: "Imagina-te a mim/ A teu lado inocente/ A mim, a essa mistura/ De piedosa, erudita, vadia/ E tão indiferente” (Hilst, 2005, p.26).

A leitura de Poemas malditos, gozosos e devotos permite verificar a representação do drama erótico-sacrificial: em um primeiro momento, a subjetividade lírica se projeta na busca do objeto de desejo se anulando e configurando como vítima, enquanto o enxerga como grande sacrificador. É desse jogo que se estabelece, no discurso poético, a tensão entre alto e baixo, sublime e grotesco, transcendência e materialidade, dialética presente e tão ao gosto da literatura de Hilda Hilst. As personas hilstianas não se intimidam diante dos interditos que lhe negam acesso ao conhecimento de seu objeto de desejo, e o sistema sacrificial se revitaliza, dando vazão às figuras participantes do ofício: vítima que ironicamente se autoentrega, a exemplo dos mártires, a seu sacrificador, nomeado comumente por "meu Deus":

É rígido e mata

Com seu corpo-estaca.

Ama mas crucifica.

O texto é sangue

E hidromel

É sedoso e tem garra

E lambe teu esforço

Mastiga teu gozo

Se tens sede, é fel.

Tem tríplices caninos.

Te trespassa o rosto

E chora menino

Enquanto agonizas. 
É pai filho e passarinho.

Ama pode ser fino

Como um inglês.

É genuíno. Piedoso.

Quase sempre assassino.

É Deus.

(Hilst, 2005, p.29)

O poema se constrói em sete estrofes de versos curtos, o que lhe confere um ritmo acelerado, e cada uma delas contém um determinado número de versos: a primeira: três; a segunda: quatro; a terceira: dois; a quarta: quatro; a quinta: um; a sexta: três; a sétima: dois. O que mais chama atenção aqui é a forma assertiva pela qual o poema se enuncia, notada em outros poemas da mesma coletânea. O sujeito lírico se mostra textualmente enquanto fala que tenta nomear uma força que lhe vem de fora, presença que irrompe no plano do discurso. Na primeira estrofe (versos 1-3), o Outro é inicialmente nomeado pela coordenação entre um predicativo, "rígido", e um verbo, "matar", quebra do paralelismo paradigmático que confere ao discurso, logo de início, uma desordem erótico-textual, desordem própria do objeto versado, visto que aponta para sua própria incoerência enquanto ente: "Ama mas crucifica". Nesse sentido, esse terceiro verso da primeira estrofe deixa entrever o objeto de desejo da realidade poética, o Deus da mitologia judaico-cristã e a tradição religiosa é ressignificada disforicamente, "corpo-estaca" que encontra seu par sonoro em "mata".

$\mathrm{Na}$ segunda e terceira estrofes, outro objeto versado entra em cena no discurso poético: o "texto", e os versos de 4 a 9 discorrem sobre ele e apontam para o próprio processo de escritura dos poemas de todo o conjunto. Ao enxergarmos nesses poemas os ofícios do sacro, eles têm uma função, portanto, dentro do rito poético: dar

5 PoemaVII. 
traços à "ideia de Deus", ou seja, de ser espaço para que essa ideia figure, mas também a função de "alimentá-la" em sua condição de texto vitimário, "sangue" e "hidromel", signos que estabelecem uma relação entre a poesia e o sagrado, "texto" que, por sua desordem, tanto é o "sangue" da imolação que se derrama em todo o conjunto quanto "hidromel", mistura fermentada de água e mel que, na mitologia nórdica, como bem apontou Souza (2008, p.71), é a bebida preferida dos deuses. Ademais, as atribuições dadas pelo eu lírico ao "texto" estabelecem uma confluência significativa com o Outro que "ama mas crucifica", o que faz o leitor se perguntar: para se versar sobre o Outro, "o texto", enquanto realização da experiência, deve conter os mesmos atributos do versado?: "É sedoso e tem garra/ E lambe teu esforço// Mastiga teu gozo/ Se tens sede, é fel". Ao "texto", portanto, são atribuídas as mesmas características animalescas - matar, "garra", lamber, mastigar - e contrastantes "sangue", "hidromel" e "fel" - do objeto de desejo poético.

Nas quarta e na quinta estrofes, há referência à unidade trina da mitologia católico-cristã, referência direta ao Deus bíblico que é "Pai", "Filho" e "Espírito Santo". Os versos 10 e 11 guardam em si essa trindade nos signos "tríplices" e "trespassa"; contudo, na realização textual, essa trindade é rebaixada ao ser aliada ao paradigma animal e violento, dado pelo substantivo plural "caninos" e o verbo trespassar, sinônimo aqui de furar e rasgar, ironia que se concretizará no verso 14, em destaque do poema: "É pai filho e passarinho". Nesse sentido, o texto mostra, tal qual o Outro, as "garras" do seu "corpo-estaca" em três momentos entre as sexta e sétima estrofes, três assertivas à figura trina que se mostrou anteriormente: "Pode ser fino/ Como um inglês/ É genuíno. Piedoso// Quase sempre assassino.", três acordes que antecipam a nota final: "Deus", signo que guarda em si todos os predicativos enunciados anteriormente, imagem à qual é admitida a violência revelada pelo discurso lírico, que também a ironiza, conformidade entre contrastes que podem ser lidos até mesmo em um plano vertical de significância, realizado, por exemplo, entre a isotopia e isofonia entre os signos "passarinho" e "assassino". 
A figura divina é transcriada no espaço do poema, enunciado em sete estrofes, composição que mantém diálogo com a criação divina do mundo presente no Gênesis, no qual se afirma que Deus criou o mundo em sete dias: "foram concluídos o céu e a terra com todo o seu exército. No sétimo dia, Deus terminou todo o seu trabalho; e no sétimo dia, ele descansou de todo o seu trabalho" (Bíblia Sagrada, 1990, p.15). As "setes faces" do poema se propõem então a criar uma imagem de "Deus" dita por uma semântica da violência e da dominação, "corpo-estaca" que "ama mas crucifica”, jogo sacrificial e textual que reconhece a força ativa e destrutiva do objeto versado na medida em que, a partir de uma desordem verbal, coordena signos de paradigmas tão diferentes, corpo textual que, num crescente, sempre crescente, deixa transparecer o excesso. Até a última nomeação, "Deus", a enunciação envereda pelo caminho da violação, e, ao desnudar o Outro, o "texto" também se torna laboratório de experiências em que o sagrado é esmiuçado na representação.

Nesse universo, o mecanismo sacrificial é transcriado e o erotismo representado não é somente o da busca pelo Outro, mas sim o que esse embate acarreta, ou seja, a desordem da continuidade perdida que se mostra no jogo erótico e o "horror", o qual atemoriza e fascina, intrínseco à guerra - ainda que entre os amantes -, ao assassínio, ao derramamento de sangue próprio das imolações e à subjetividade que passará a figurar, portanto, martirizada. Poesia na qual os signos "carne" e "sangue" são recorrentes; e, transpondo os interditos que limitam o acesso ao Sagrado, esse sujeito goza, a partir de então, do mundo da transgressão, dos excessos e da animalidade que não dispensa a bestialidade:

É neste mundo que te quero sentir É o único que sei. O que me resta.

Dizer que vou te conhecer a fundo Sem as bênçãos da carne, no depois, Me parece a mim magra promessa.

Sentires da alma? Sim. Podem ser prodigiosos. 
Mas tu sabes da delícia da carne

Dos encaixes que inventaste. De toques.

Do formoso das hastes. Das corolas.

Vês como fico pequena e tão pouco inventiva?

Haste. Corola. São palavras róseas. Mas sangram.

Se feitas de carne.

Dirás que o humano desejo

Não te percebe as fomes. Sim, meu Senhor,

Te percebo. Mas deixa-me amar a ti, neste texto

Com os enlevos

De uma mulher que só sabe o homem.

(Hilst, 2005, p.31)

O poema VIII, composto por dezessete versos divididos em três estrofes, aponta para a esfera do excesso. O tom místico da experiência entre o sujeito e seu Deus empresta para si a notação do discurso amoroso. Primeiramente, estabelece-se uma relação entre os amantes própria do sacrifício: a de servo e Senhor, relação presente em todo o conjunto. De acordo com Simone Weil, a única relação esperada entre o fiel e seu Deus é a relação verticalizada entre servo e Senhor, na qual o primeiro tem a obrigação exclusiva de confiar e obedecer, sendo essa um dos dogmas da fé religiosa: "é verdade que, no domínio da ação, é necessário fazer tudo que nos seja mandado, ao preço de não importa que grau de esforço, de fadiga e de sofrimento, por aquilo de que quem desobedece não ama" (Weil, 1987, p.97). Entretanto, em Poemas malditos, gozosos e devotos, tal relação é pretensiosamente desestabilizada pelo uso do segundo pronome pessoal tu e seus variantes, como signo de tratamento para com seu "Senhor", visto que essa forma de tratamento aproxima sujeito e objeto versado: "É neste mundo que te quero sentir...", forma própria do discurso erótico que evidencia o jogo de aproximação da persona lírica para a "Ideia de Deus" representada. 
O poema como espaço da aventura rumo ao Outro apresenta e nomeia dois "sentires" na relação entre homem e divindade: o do corpo, ou da "carne", e o da "alma". Dentro do mundo cristão em que esta subjetividade se insere, o segundo "sentir" - o da alma -é privilegiado na experiência mística; o corpo somente é empecilho para a elevação ao divino, e o crente ou o neófito que se propõe a essa experiência deve, essencialmente, ultrapassar os sentidos a fim de que a alma se eleve ao paraíso tão prometido. Segundo Foucault (2004, p.62), devido à moral burguesa e cristã, a sexualidade no Ocidente esteve sempre "votada ao silêncio". Ainda que as interdições à sexualidade já existissem no mundo romano antes do advento do cristianismo, este, com seu ascetismo, muito contribuiu para as proibições morais contra a sexualidade. Para Foucault, a maior contribuição do cristianismo para a história da sexualidade está nos "mecanismos de poder" praticados pelo cristianismo para manter a moral sexual (a monogamia, o casamento, o sexo voltado somente à reprodução etc.). E esses "mecanismos de poder", introduzidos no mundo ocidental pela moral cristã para valorizar as interdições, estão sobretudo naquilo que o filósofo francês denominou de "pastorado", isto é: "indivíduos que desempenhavam, na sociedade cristã, o papel de condutores, de pastores em relação aos outros indivíduos que são como suas ovelhas ou o seu rebanho" (Foucault, 2004 , p.65). Esse poder pastoral não consiste em um poder "bélico", mas sim "benfazejo", no sentido daquele que conduz e cuida dos indivíduos dos quais se propôs a tomar conta:

[... em outras palavras, o poder pastoral não tem por função principal fazer mal aos inimigos; sua principal função é fazer o bem em relação àqueles de que cuida. Fazer o bem no sentido mais maternal do termo significa alimentá-lo, garantir sua subsistência, oferecer-lhe um pasto, conduzi-lo às fontes, permitir-lhe beber, encontrar boas pradarias. Consequentemente, o poder pastoral é um poder que garante ao mesmo tempo a subsistência dos indivíduos e a subsistência do grupo, diferentemente do poder tradicional, que se manifesta essencialmente pelo triunfo sobre os dominados. 
Não é um poder triunfante, mas um poder benfazejo. (Foucault, 2004, p.66)

Para a moral cristã, o pastor deve se servir de sua posição de vigilante para obrigar seu "rebanho" na busca da "salvação", visto que a "salvação" individual também conduz à salvação de todo o grupo. Weil enfatiza que o crente cristão deve, sobretudo, ser obediente em relação aos dogmas e mandamentos de "seu" Deus, e Foucault justamente enfoca essa "obediência" nos mecanismos de poder pastoral do cristianismo. Ser obediente, portanto, passa a ser uma norma e, ainda mais, um reconhecimento da vontade do outro, a qual se mistura com a vontade do próprio Deus. O "rebanho" deve ser obediente às vontades de seu pastor, as quais são também as vontades de Deus, visto que ele é aquele que conhece "o interior do que se passa na alma, no coração, no mais profundo dos segredos do indivíduo. Esse conhecimento da interioridade dos indivíduos é absolutamente exigido para o exercício do pastorado cristão" (Foucault, 2004, p.69). Nessa óptica, o pastor é aquele que salvaguarda o casamento e a sexualidade voltada somente para a reprodução, aquele que envilece o prazer e controla a "carne" de seu rebanho, "concebida como alguma coisa da qual era preciso desconfiar, alguma coisa que sempre introduzia no indivíduo possibilidades de tentação e de queda" (Foucault, 2004, p.71). Assim, são esses os mecanismos de poder exercidos pelo cristianismo para manter uma "moral", os quais acabaram por delinear uma subjetividade cristã que muito guiou o pensamento ocidental nos meandros da sexualidade:

[...] é pela constituição de uma subjetividade, de uma consciência de si perpetuamente alertada sobre suas próprias fraquezas, suas próprias tentações, sua própria carne, é pela constituição dessa subjetividade que o cristianismo conseguiu fazer funcionar essa moral, no fundo mediana, comum, relativamente pouco interessante, entre o ascetismo e a sociedade civil. Creio que a técnica de interiorização, a técnica de tomada de consciência, a técnica de 
despertar de si sobre si mesmo em relação às suas fraquezas, ao seu corpo, à sua sexualidade, à sua carne, foi a contribuição essencial do cristianismo à história da sexualidade. (Foucault, 2004, p.71)

Contudo, o poema de Hilst deflagra um outro "sentir" - o da carne -, e o discurso poético o reveste de uma euforia semântica; o conhecimento do Outro não somente deve partir da esfera e do esforço do intelecto e do saber, metaforizado pelos "sentires da alma", mas também deve tomar o "sentir" do corpo, no qual residem as "bênçãos da carne". Toda a escolha lexical do poema se insere no paradigma do corpóreo: "carne", "sentir", "toques", "sangram", "fomes", até mesmo as escolhas metafóricas, que conotam o corpóreo e o sexual: "encaixes", "hastes", "corolas”. Como um tratado, há nessa aventura a valoração do conhecimento do sagrado através dos excessos do corpo e são esquecidas, ou deixadas por ora de lado, as "magras promessas" dadas pela religião, de se conhecer a Deus no "depois" da morte física, quando todas as criaturas pretensamente se encontrarão cara a cara com seu Criador: "Sentires da alma? Sim. Podem ser prodigiosos./ Mas tu sabes da delícia da carne/ Dos encaixes que inventaste...”. O jogo poético apresenta uma euforia "da carne" e a via desta para se aproximar do Sagrado; vencer os interditos é se encorajar para o mundo das transgressões, da festa do corpo e do prazer, ou até mesmo da festa do texto, onde se pode ou não ter o vislumbre do amor do seu "Senhor". Os dois primeiros versos do poema - "É neste mundo que te quero sentir./ É o único que sei. O que resta." - já afirmam o verdadeiro desejo dessa mulher de conhecer o objeto de desejo que é seu Deus na esfera do corpo, o qual lhe é tão familiar, pois é somente "uma mulher que só sabe o homem", aquela que sabe e aceita o prazer proporcionado pelo encontro erótico entre os corpos.

Com essa exaltação da transgressão do corpo, a poética de Hilda Hilst desmantela a lógica católico-cristã que interpenetra na representação de sua poesia. O primeiro poema do conjunto evidencia que o mundo católico-cristão funda essa poesia; a figura do Cristo sacrificado e suspenso no madeiro se transforma em significante 
dessa transcriação: "Mandou seu filho/ Ser trespassado// Nos pés de carne/ Nas mãos de carne/ No peito vivo. De carne." (Hilst, 2005 , p.13). E se essa óptica religiosa reitera o tempo todo que a esfera do corpo não deve estar presente na relação homem - Deus, a novena profana de Hilst, do outro lado, insiste na focalização do corpo "de carne" do Cristo, signo martírico que dá origem aos ritos do catolicismo, visto que o sacrifício, ainda que simbólico, é relembrado e atualizado diariamente nas missas. Bataille (1987) afirma que a religiosidade cristã se opõe ao "espírito da transgressão", próprio do sagrado pagão; essa religiosidade nasce da tentativa de superação da violência contida na transgressão, pregando sempre o amor ao próximo, a obediência e a salvação. Se, para o mundo pagão, o sagrado só irrompe na transgressão do interdito, o sagrado do mundo cristão rejeita a "impureza" das transgressões, rejeitando a mácula, o excesso e o "pecado".

Ao condenar a impureza, o mundo cristão também condenou o erotismo, passando, desse modo, a valorizar a família, dentro da qual as atividades sexuais deveriam ser meramente reprodutivas, $\mathrm{e}$ também baniu de suas instituições as pessoas de vida livre, sendo que toda atividade sexual que extrapolasse o casamento passou a ser considerada profana, e não mais sagrada. Portanto, o signo do corpo passou a ser metonímia dessa "impureza", e a aventura ao paraíso prometido pela religião passou a ser realizada pelos "sentires da alma", excluindo a exuberância e as "delícias da carne". Seja evidenciando a figura do Cristo a partir de sua "carne", seja exaltando os "enlevos" do corpo ou enunciando nesses versos uma semântica da violência e do "excesso", a poesia de Hilst se reveste da "impureza" ou maldição que o cristianismo desprezou, mas que ainda está presente em sua liturgia. Esses versos impuros reafirmam a experiência mística em martírica, deslocando a efusão dessa forma de conhecimento de Deus para as partes "baixas" do corpo, transformando a dor em prazer, satisfação em ver sangrar as "hastes" e as "corolas" que são "feitas de carne". Nota-se que a carne do poema, como corpo de linguagem, também sofre uma cisão ou sangramento próprio da relação erótica: o verso 12, que sozinho 
compõe a segunda estrofe, aparece deslocado tanto da primeira estrofe, composta por onze versos, quanto da terceira, composta de cinco versos, corpo que, visualmente falando, foi cortado ao término do verso 11 e dividido, portanto, em três partes. Nesse sentido, o "texto" (verso 15) alia em si forma e conteúdo, signos que experimentam tanto a alegria do amor ao Outro quando a dor de se saber, ainda que textualmente, destituído na relação erótica.

Prazer e dor formam uma dupla surpreendente e suas relações são paradoxais. À medida que cresce e se faz mais intenso, o prazer roça a zona da dor. A intensidade da sensação nos leva ao polo oposto; uma vez tocado esse extremo, opera-se uma espécie de reversão e a sensação muda de signo. [...] Em seguida, destruídas as hierarquias tradicionais, ele erige uma nova arquitetura: o verdadeiro prazer, o prazer mais forte, intenso e duradouro é dor exasperada que, por sua própria violência, se transforma de novo em prazer. (Paz, 1999, p.64-5)

Prazer é dor; dor é prazer. Polos que, de acordo com Paz (1999, p.66), se encontram no movimento próprio do sensualismo sádico. Nesse sentido, a sensualidade em Hilst não é somente reconciliação de dois corpos que se unem em um único abraço, mas também dilaceração entre corpos, mãos que têm "unhas", "boca" e "dentes", distanciando-se ironicamente de um erotismo sublime da tradição dos Cantares bíblicos e da mística cristã. O erotismo em Hilst, admiravelmente sacrificial, insere-se nas manifestações destruidoras da sexualidade, haja vista as orgias e as mutilações. A persona lírica no poema VIII se confessa conhecedora das "fomes" do seu "Senhor" e o discurso poético se concretiza como discurso que alimenta o desejo: "É neste mundo que te quero sentir...". Todo o drama se enuncia a partir da esfera do delírio, sendo somente o "texto" o espaço de concreção do drama do encontro sensual e sacrificial. É dele que se desprendem os participantes do ofício, vítima e sacrificador, sendo que, à primeira vista, essa "mulher" se posiciona a partir do rebaixamento tão esperado da parte que lhe cabe no jugo: 
Poderia ao menos tocar

As ataduras da tua boca?

Panos de linho luminescentes

Com que magoas

Os que te pedem palavras?

Poderia através

Sentir teus dentes?

Tocar-lhes o marfim

E o liso da saliva

O molhado que mata e ressuscita?

Me permitirias te sentir a língua

Essa peça que alisa nossas nucas

E fere rubra

Nossas humanas delicadas espessuras?

Poderia ao menos tocar

Uma fibra desses linhos

Com repetidos cuidados

Abrir

Apenas um espaço, um grão de milho

Para te aspirar?

Poderia, meu Deus, me aproximar?

$\mathrm{Tu}$, na montanha.

Eu no meu sonho de estar

No resíduo dos teus sonhos?

(Hilst, 2005, p.34-5)

No drama sacrificial e erótico, apesar de ser sua personagem mais proeminente, a vítima sempre ocupa uma posição rebaixada se a posicionarmos diante de seu sacrificador. No caso do poema IX, enunciado por seis estrofes assimétricas, esse rebaixamento é plas- 
mado principalmente pela forma como o sujeito lírico se dirige ao seu interlocutor: por meio do futuro do pretérito, forma que guarda em si a hipótese, a incerteza e a fantasia, mas também a "cortesia", ou neste caso, a submissão: "Poderia, meu Deus, me aproximar?". Aliada a essa submissão, a enunciação se faz também por meio de versos interrogativos, tão ao gosto dos poemas do conjunto, pedidos e súplicas que, no discurso poético, nunca são atendidos. Nesse jogo de poder e permissão, a diferença entre o sujeito lírico e o seu "Deus" é tamanha que, no primeiro movimento, o sujeito da enunciação se encontra oculto na sintaxe do poema, sendo que o signo "Eu" figurará somente no fechamento do conjunto: "Eu no meu sonho de estar/ No resíduo dos teus sonhos?”. Toda a pulsão discursiva vem da esfera dos sentidos, a exemplo dos verbos "tocar" (versos 1, 8 e 15), "sentir" (7 e 11), "alisar" (verso 12), "aspirar" (verso 20) e "aproximar" (verso 21) e, dando continuidade ao que foi dito no poema VIII, as "bênçãos da carne" são enaltecidas e a imagética do Outro se delineia a partir do corpo: “boca” (verso 2), “dentes" (verso 7), "saliva" (verso 9), "língua” (verso 11).

No seu "sonho de estar", o sujeito lírico dá um corpo à ideia tão pensada do seu "Deus", pois, de acordo com Paz (1995, p.78), o elemento mais proeminente no erotismo é o corpo: "ama-se uma pessoa, não uma abstracção". Sendo assim, essa mulher que "só sabe o homem" enfatiza nesses acordes devotos e malditos a presença enquanto corpo de seu objeto de desejo; e, nesse sentido, não é gratuita a figura do Cristo, o deus que se fez homem "de carne", reiterada ao longo do conjunto. $\mathrm{O}$ tom de súplica se alia aqui à sedução pela humildade, e o gesto do "menos" intenta dissimuladamente se fazer vítima para ser alimento das "fomes" do seu Deus; portanto, a subjetividade lírica se transfigura neste "grão de milho", imagem que revela a pequenez de sua condição vitimária diante de uma alteridade que "mata e ressuscita", conjunção em destaque no

6 Nota-se que, em todo o conjunto dos Poemas malditos, gozosos e devotos, as partes do corpo marcam presença, principalmente aquelas de maior apelo erótico: pés, mãos, boca, língua. 
verso 10, destacado e centralizado no poema, ações que apontam tanto para a finitude quanto para a redenção, contrários tão próprios da dialética do sagrado. Nesses versos do "menos", escavam-se mínimos opostos da ânsia pelo objeto devotado, que tanto podem oferecer o vazio da experiência, a exemplo do signo oca, encerrado em "boca", quanto a euforia metaforizada em sol, anagraticamente presente no sintagma "liso da saliva". Nesse sentido, o tom "cortês" dessa voz lírica não pode ser lida fora da ironia, uma vez que a única certeza dada pelo poema é a distância do Outro, a exemplo do único verso afirmativo do poema: "Tu, na montanha". A voz lírica empresta da mística a imagem da aventura existencial rumo à ascensão e ao desprendimento das coisas ordenadas para a união com Deus, os quais não se separam do esforço de tal empresa. A resposta da empresa, que se tem após se ler o verso 21, "Poderia, meu Deus, me aproximar?", é ressaltada pela verticalidade estabelecida entre os entes "Tu" (verso 22) e "Eu" (verso 23), posicionamento que não só se apresenta em termos visuais, mas também sonoros: o tom agudo do primeiro termo se contrapõe ao grave do segundo: /ú / X /êe/, enfatizando, por fim, a distância entre os amantes e a fantasia do sujeito de estar nos "resíduos" do pensamento do Outro, ou seja, de se saber também sonhada e desejada.

Daí também que a forma mais sistemática do mistério divino nos poemas seja curiosamente a que o título não nomeia: os "mistérios dolorosos". Para eles, sobretudo, se dispõe o poeta, que reconhece perfeitamente que o pensamento de Deus é, em essência, uma entrega à mais apavorante solidão. Isto é, pensar Deus é, no limite, compor na própria carne um discurso de ausência, de desejo sem nenhuma correspondência. (Pécora, 2005, p.11-2)

De acordo com Bataille, o erotismo é uma experiência solitária, que não pertence ao mundo ordinário; sempre furtivo, ele faz parte das nuances "secretas" da vida do homem. Ainda que se escrevam poemas, narrativas ou conferências, por exemplo, sobre o erotismo, o interdito que recai sobre ele ainda se faz presente em nossa época, o 
que o exclui da ordem do discurso, "como se não pertencesse à nossa vida presente, como se fosse uma realidade distante que só nos é acessível sob uma condição: que nós saiamos do mundo que ora estamos para buscar abrigo na solidão" (Bataille, 1987, p.234). Sendo de uma intensidade extrema, a emoção provocada pelo erotismo nos afasta do convívio social e a sinfonia do erótico é uma música de silêncios. Ainda que Bataille reconheça a diferença de natureza entre a experiência erótica e a experiência da santidade, ${ }^{7}$ ambas exigem do ser o adeus ao "mundo lá fora", visto que o mundo profano, fundado na ordem, exclui os momentos de intensa emoção e desvario, temente que é da desordem das transgressões, e o erótico, tal qual a mística, é animado somente pelo desejo desvairado pelo Outro.

O arrebatamento do erótico é do "Eu" para o "Tu", tentativa de pôr fim, ainda que por um curto prazo, à distância que separa o sujeito do topo da "montanha". Descomedidamente, o amante vive a ilusão da continuidade, "sonho de estar" na unidade pretensa enxergada no amado, a exemplo do poema VI:

Se mil anos vivesse

Mil anos te tomaria

Tu.

E tua cara fria.

Teu recesso.

Teu encostar-se

Às duras paredes

De tua sede.

Teu vício de palavras.

Teu silêncio de facas.

As nuas molduras

De tua alma.

7 Entretanto, para Bataille, diferentemente do erotismo, os discursos da santidade são sempre aceitos pela ordem social, a exemplo dos sermões. 
Teu magro corpo

De pensadas asas.

Meu verso cobrindo

Inocências passadas.

Tuas.

Imagina-te a mim

A teu lado inocente

A mim, e a essa mistura

De piedosa, erudita, vadia

E tão indiferente

Tu sabes.

Poeta buscando altura

Nas tuas coxas frias.

Se eu vivesse mil anos

Suportaria

Teu a ti procurar-se.

Te tomaria, Meu Deus,

Tuas luzes. Teu contraste.

(Hilst, 2005, p. 27-8)

A ansiedade da procura, enunciada a partir de trinta versos, estabelece nos dois primeiros versos do conjunto a hipótese: "Se mil anos vivesse/ Mil anos te tomaria.", fala que afirma a veemência e a extensão sem fim da experiência do Outro, próprias da desmesura da paixão. Nessa fala apaixonada só figuram os contornos do "Tu", signo que, por exemplo, se destaca por si só no terceiro verso da primeira estrofe, afirmando-se textualmente, e o mundo "lá fora" não cabe no gozo dessa experiência solitária. A partir do quarto verso da primeira estrofe, a persona lírica passa a nomear imageticamente o Outro: "tua cara fria" (verso 4), "Teu recesso" (verso 5), "Teu encostar-se/ Às duras paredes/ De tua sede" (versos 6, 7 e 8), "Teu vício de palavras" (verso 9), "Teu silêncio de facas" (verso 10), "tua alma" 
(verso 12), "Teu magro corpo/ De pensadas asas" (versos 13 e 14), "tuas coxas frias" (verso 25), "Teu a ti procurar-se." (verso 28), “Tuas luzes. Teu contraste." (verso 30), nomeação que alimenta esse "vício de palavras" que a subjetividade lírica reconhece na outridade. Essa fala do excesso, signo que se desdobra de "Teu recesso", não deixa de reconhecer e reafirmar, a exemplo de alguns dos outros poemas do conjunto, a disforia da aventura de se pensar o seu "Deus", experiência fantasiosa que tenta dar "asas" a um "magro corpo", o qual, muitas vezes, retribui a ansiedade apaixonada com um "silêncio de facas". É significativa, portanto, a relação simétrica que o nono e o décimo versos estabelecem entre si: "Teu vício de palavras./ Teu silêncio de facas.”, ambos com seis sílabas métricas, simetria que aponta para o próprio estado discursivo, que alimenta seu objeto de desejo com "palavras" e, em troca, acolhe suas "facas". Na sexta estrofe, é resumido o drama apaixonado de alcançar o que já foi nomeado anteriormente pela metáfora da "montanha": "Poeta buscando altura/ Nas tuas coxas frias".

Se buscar "altura" é um processo ainda em andamento, basta notar a forma do gerúndio pela qual o verbo "buscar" se enuncia, e o recurso da repetição, neste poema VI, se mostra também significativo não só como recurso para alimentar este "vício de palavras", mas também como forma de concreção no discurso poético do desatino da paixão e da infinidade do desejo, emoções ainda latentes e obstinadas: "Se mil anos vivesse/ Mil anos te tomaria."; "Teu recesso./ Teu encostar-se", "Teu vício de palavras.", "Teu silêncio de facas, "Teu magro corpo"; "Imagina-te a mim/ A teu lado inocente/, A mim..."; "Teu a ti procurar-se./ Te tomaria, meu Deus,/ Tuas luzes. Teu contraste.”. O sonho de conjunção com esta "altura" se materializa no texto, material do desejo, na recorrência ofuscada do signo TEU, signo de continuidade da desordem sacrificial, erótica e poética, no qual a vítíma, o EU, encontra a unidade tão sonhada com o seu sacrificador, o TU: TEU $=$ TU + EU. Esta "mistura" da passagem da desordem para a ordem dará, então, os traços ambíguos próprios da vítima do sacrifício, a qual se reconhece "piedosa", "erudita", "vadia", "indiferente" e "poeta", 
adjetivos que apontam tanto para a esfera do "baixo", ou do "impuro", quanto para a esfera do "alto", ou do "puro":

[...] não é o caso aqui de explicar longamente por que o profano entra, desse modo, em relações com o divino; é que ele aí encontra a fonte da vida, as condições mesmas de sua existência, e assim tem todo o interesse em se aproximar. Mas como entender que ele só se aproxime permanecendo à distância? Como entender que só se comunique com o sagrado por via de um intermediário? Os efeitos destrutivos explicam em parte esse estranho procedimento. Se as forças religiosas são em si mesmas o princípio das forças vitais, são de uma tal natureza que seu contato é perigoso para o vulgo. Sobretudo quando atingem um certo grau de intensidade, não podem se concentrar num objeto profano sem destruí-lo. [...] Eis por que intermediários se introduzem [...], sendo que o principal é a vítima. (Hubert e Mauss, 2005, p.104)

A poesia de Hilst só se torna espaço de representação e interrogação ao sagrado porque sua subjetividade encarna em si a figura da vítima. Ao se configurar como vítima e atrair para sua linguagem as polarizações próprias do intermediário entre o mundo profano e o sagrado, a divindade aí irrompe como movimento das transgressões ilimitadas, conjunção entre o puro e o impuro, continuidade dada pela violência que desestabiliza, mas que gera as "bênçãos da carne". Ao inundar-se de religiosidade, o ser é isolado, pois quem penetra no mundo sagrado, torna-se também sagrado, abnega-se de si e se oferece como alimento às divindades, e o discurso poético deixa entrever a dor e o sangue derramado dessa imolação.

Ao se configurar como vítima, o canto da persona é emitido através de despojos e resíduos da imolação sacrificial transfigurada e revitalizada, linguagem que permite em sua tessitura o transbordamento do excesso, incorporando a seu espaço textual elementos que, na violação, servem de alimento para o jogo de ausência e presença construído nesse jugo sacroerótico. Melodia para "carnes", "sangue”, "ossos", "boca”, "língua”, "hastes", "corolas”, "cabe- 
ça”, "lava”, "gozo”, “dores”, "grito”, léxico que não se interdita diante do mundo das "delícias" ilimitadas, em que euforia e disforia se agregam na continuidade das imagens que forjam esse discurso descomedido e desordenado. Mas, por fim, esses acordes "malditos", "gozosos" e "devotos" acabam por desconstruir o seu próprio esquema fundante: a subjetividade lírica figura incontestavelmente como vítima enxergando sempre o tu como o grande sacrificador? Se atentarmos para o caráter vitimário da subjetividade lírica, ela não é, nesse sentido, passiva e obediente como as vítimas que se autoentregam nos ritos religiosos. Essa desobediência, velada, desestabiliza o poder de "paternidade", mencionado por Foucault, conferido à divindade, a exemplo do poema XVII: "Penso que tu mesmo cresces/Quando te penso. E digo sem cerimônias/Que vives porque te penso" (Hilst, 2005, p.53). A razão crítica daquela que verseja põe mesmo em questão a própria existência do seu objeto de desejo, figurando-o somente no delírio lúcido da poesia, canto que faz que nos recordemos, enquanto presença erótica de leitura, da mesma angústia que funda as Elegias do poeta alemão Rainer Maria Rilke: "Quem, se eu gritasse, ouvir-me-ia na hierarquia/ dos anjos?” (Rilke, 2002, p.127).

\section{Referências bibliográficas}

BATAilLE, G. O erotismo. Trad. Antonio Carlos Viana. Porto Alegre: L\&PM, 1987.

BÍBLIA SAGRADA. Trad. Ivo Storniolo e Euclides Martins Balancin. São Paulo: Paulus, 1990.

FOUCAULT, M. Sexualidade e poder. In:__. Ética, sexualidade e política. Trad. Elisa Monteiro, Inês Audran Dourado Barbosa. Rio de Janeiro: Forense Universitária, 2004.

HATHERLY, A. A idade da escrita e outros poemas. São Paulo: Escrituras, 2005.

HILST, H. Poemas malditos, gozosos e devotos. São Paulo: Globo, 2005. HUBERT, H.; MAUSS, M. Sobre o sacrifício. Trad. Paulo Neves. São

Paulo: Cosac Naify, 2005. 
PAZ, O. O arco e a lira. Trad. Olga Savary. Rio de Janeiro: Nova Fronteira, 1982.

. A chama dupla: amor e erotismo. Trad. José Bento. Lisboa: Assírio \& Alvim, 1995.

. Um mais além erótico: Sade. Trad. Wladir Dupont. São Paulo: Mandarim, 1999.

PÉCORA, A. Nota do organizador. In: HILST, H. Poemas malditos, gozosos e devotos. São Paulo: Globo, 2005, p.9-12.

RILKE, R. M. Os sonetos a Orfeu; Elegias de Duíno. Trad. Karlos Rischbieter e Paulo Garfunkel. Rio de Janeiro: Record, 2002.

SOUZA, L. N. do A. O sagrado como busca em Poemas malditos, gozosos e devotos, de Hilda Hilst. Dissertação (Mestrado em Letras). Instituto de Biociências, Letras e Ciências Exatas, Universidade Estadual Paulista, São José do Rio Preto, 2008.

WEIL, S. A espera de Deus. Trad. Equipe da Editora Cultural Espiritual. São Paulo: ECE, 1987. 


\section{Traduzir as faces de Deus}

Hsiao-Shih Lee

Ao abrir o poemário Sobre a tua grande face, de Hilda Hilst, o leitor encontra-se com um formato peculiar. Passada a página de dedicatória, Hilst utiliza um kanji - um caractere japonês com origem na lingua chinesa, 天 (Fig. 1), que significa o céu. Contudo, para o leitor típico do português, não se supõe que o significado seja acessível. Nesse caso, o que confronta o leitor é o impacto visual do caractere: a tinta preta no papel branco, a maneira pela qual as duas pinceladas horizontais grossas acima contrastam com as duas pinceladas mais finas que estendem para baixo. Esse caractere, como os outros no livro, é escrito na caligrafia pelo artista nipo-brasileiro Kazuo Wakabayashi, nascido em 1931, que imigrou para o Brasil em 1961. Ao virar a página, o leitor vê o primeiro poema do livro na página reversa desse caractere e, na página oposta, o segundo caractere, 人, com o segundo poema no lado reverso (Fig. 2). O livro continua assim até o final, depois de dez poemas.

Em termos de composição, o segundo caractere aparece no primeiro caractere. Ainda que essa progressão visual de ver o caractere seguinte no caractere anterior não seja um padrão consistente na série do kanji spresentada no livro, o seu uso sugere uma sequência que é cíclica, como o retorno a 天 antes do poema final. Desse modo, apesar de não saber o significado dos caracteres, o leitor 


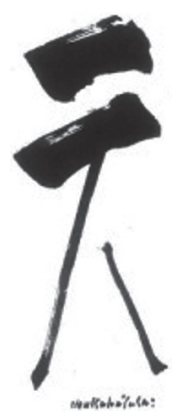

Figura 1
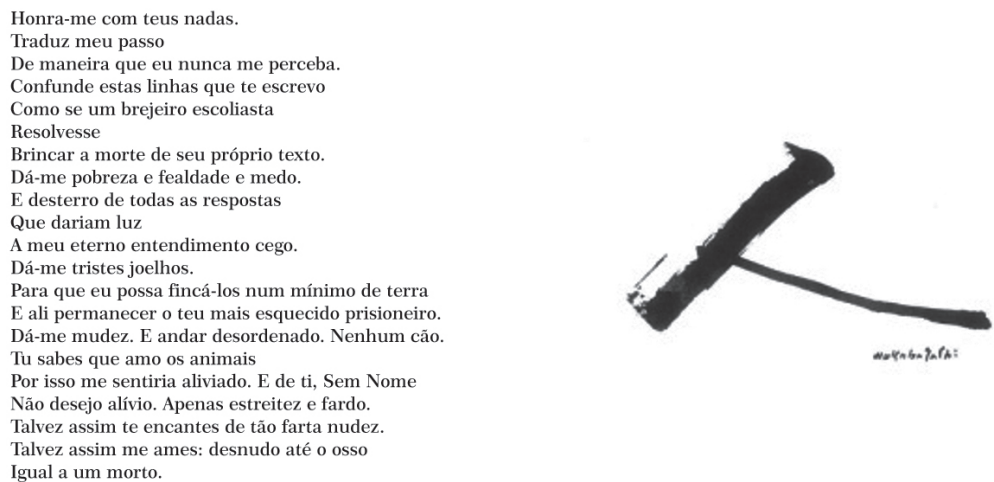

Figura 2

pode discernir alguma informação por meio dos atributos visuais e sequenciais.

Esse ensaio começa com uma descrição física do livro porque este é um ponto chave no presente estudo, que enfoca os elementos formais da colaboração entre Hilst e Wakabayashi. A questão principal gira em torno da presença desses kanjis caligráficos, já que os poemas não contêm nenhuma referência japonesa. Além disso, o fato de que os significados dos kanjis não são explicitados é ainda mais curioso devido a seu formato. $\mathrm{O}$ formato de se colocar uma palavra de uma língua no anverso (neste caso, o kanji) e um texto mais longo em outra língua, no verso (os poemas de Hilst em português) parece o dos cartões-relâmpago. Embora esse formato possa ter 
sido mais um fruto da coincidência do que um ato intencional, não obstante merece ser analisado. No caso de se ler as páginas como se fossem cartões-relâmpagos, o contraste entre os caracteres e os poemas torna-se ainda mais óbvio, porque Hilst e Wakabayashi não oferecem traduções dos caracteres. Essa organização também enfatiza a linguagem que Hilst utiliza nesses poemas, que pode ser descrita como castiça: entrincheirada nas tradições linguísticas do português com o seu uso de palavras clássicas - até arcaicas - tanto como neologismos destros, mostrando uma relação íntima com o idioma e sua história. Embora, em certo nível, uma análise visual da série de kanji ajude a iluminar a estrutura dos poemas de Hilst como uma sequência, o propósito da justaposição dos dois elementos ainda não fica claro.

Este ensaio busca examinar a relação entre os poemas e a caligrafia, estabelecidos firmemente em tradições culturais distintas e que parecem desvinculados um do outro. Para esse propósito, é necessário que se faça um resumo da caligrafia japonesa, além da própria análise dos poemas. $\mathrm{O}$ ensaio foca-se nas ressonâncias inesperadas entre as duas técnicas e explora as questões que surgem quando se traduzem os kanjis. Seria necessária a tradução nessa forma de contato cultural, tal como apresenta o livro? De que modo a leitura é afetada quando se sabe o significado do kanji? Assim, primeiramente faremos um estudo sobre os poemas sem recorrermos aos caracteres e sobre a narrativa que se forma quando são considerados como uma sequência. Em um segundo momento, exploraremos o componente caligráfico em profundidade, contextualizando histórica e culturalmente a caligrafia como uma arte, e, por fim, examinaremos os dois elementos em conjunto.

\section{O "tu" anônimo"/polissêmico}

O título Sobre a tua grande face convenientemente fornece um ponto de partida para a análise do livro, já que propõe a pergunta sobre a identidade do "tu". Outra pergunta que emerge a partir do 
título é se o "sobre" deve ser entendido como "acerca de", ou num sentido mais físico, "acima de". Além disso, por que usar "face" em vez da palavra mais comum, como "cara"? Uma resposta possível à última pergunta pode ilustrar um dos objetivos principais do livro de Hilst. É muito provável que Hilst tenha selecionado a palavra "face" por seu significado simultâneo de "superfície," enfatizando a multiplicidade (de ser multifacetado) em vez da singularidade, que tende a se associar com o rosto humano. Por um lado, a cara é o meio pelo qual é possível reconhecer alguém, possibilitando ainda a interpretação do que uma pessoa sente, em vista das indicações não verbais. Por outro lado, também pode-se observar que a "face" é só a primeira camada das coisas, já que não se pode saber tudo o que há para saber ao se ver apenas a face de algo, já que pode ser somente um aspecto entre muitos outros. Reconhece-se essa instabilidade em expressões como "a verdade tem muitas faces". Dada essa variabilidade, não se pode fazer uma conclusão definitiva sobre o "tu" baseando-se somente no título. A sua unicidade e multiplicidade simultâneas - as suas muitas faces - é um atributo distintivo. É razoável, então, sugerir que o texto também acomoda os dois significados da palavra "sobre", tanto no sentido literal (que comunica a posição física de alguma coisa) como no sentido abstrato (a respeito de algo). A relação com o "tu" varia em conjunto com as duas interpretações: com a primeira, comunica-se uma proximidade física, enquanto a segunda pode ser empregada independentemente da ausência física do sujeito, apresentando, dessa maneira, uma questão de negociação da distância envolvida.

Quem é, então, esse "tu" que é interpelado? Pela sequência, ele aparece sob muitos nomes, principalmente como "Sem Nome", mas, também, como "DESEJADO", "Cara Escura", "Obscuro", "Soturno", e o titular "Grande Face". O nome "DESEJADO", no contexto dos poemas, é identificado como o objeto de desejo do sujeito lírico. As características contraditórias do destinatário, em segunda pessoa, manifestam-se no próprio fato de ser referido como "Sem Nome", embora seja nomeado de várias maneiras. Essas contradições afirmam-se no primeiro poema do livro: 
Honra-me com teus nadas.

Traduz meu passo

De maneira que eu nunca me perceba.

Confunde estas linhas que te escrevo

Como se um brejeiro escoliasta

Resolvesse

Brincar a morte de seu próprio texto. (Hilst, 1986, s.p.)

Apesar de se sentir honrada com o que ganha, a locutora ganha apenas "nadas" e, a despeito de obscurecer os seus passos, o "tu" é "um brejeiro" que, ao mesmo tempo, é um "escoliasta" que toma suas criações textuais tão levemente a ponto de brincar com a morte. A relação entre a autora e o texto apresentada por este símile é central ao poema e será examinada mais adiante neste ensaio. As contradições encontram-se não só na caracterização do "tu", mas também na relação romântica, carregada de paixões sadomasoquistas e pela dinâmica entre presença e ausência, ilusão e realidade, satisfação e solidão. A segunda metade do poema ilustra a relação entre a oradora e o destinatário:

E desterro de todas as respostas

Que dariam luz

A meu eterno entendimento cego.

Dá-me tristes joelhos.

Para que eu possa fincá-los num mínimo de terra

E ali permanecer o teu mais esquecido prisioneiro.

Dá-me mudez. E andar desordenado. Nenhum cão.

Tu sabes que amo os animais

Por isso me sentiria aliviado. E de ti, Sem Nome

Não desejo alívio [...]

Talvez assim me ames... (Hilst, 1986)

A oradora conscientemente renuncia a qualquer resposta ao que ela reconhece como seu "entendimento cego" e voluntariamente ajoelha-se como o "mais esquecido prisioneiro". Como poeta, ela 
ainda deseja mudez na esperança de obter o amor do "tu". Sua insistência em permanecer nesse estado é tão forte que ela rejeita a possibilidade de estar com algum cão, cuja companhia forneceria alívio desse anelo. A hierarquia de poder entre a locutora e o tu estabelece-se dessa maneira.

Porém, seria um erro tomar a locutora simplesmente como uma amante anônima num romance em grande parte não correspondido. Os leitores familiarizados com as outras obras de Hilst reconhecerão alguns dos atributos que sugerem os nomes desse "tu", como as qualidades da escuridão, da imensidão, e o enfoque no rosto. Os que visitaram a Casa do Sol - a propriedade que Hilst construiu em Campinas, na qual ela morou desde 1966 e que atualmente é sede do Instituto Hilda Hilst - lembram-se de uma longa placa na parede que documenta os muitos nomes que Hilst usou em suas obras para referir-se a Deus.

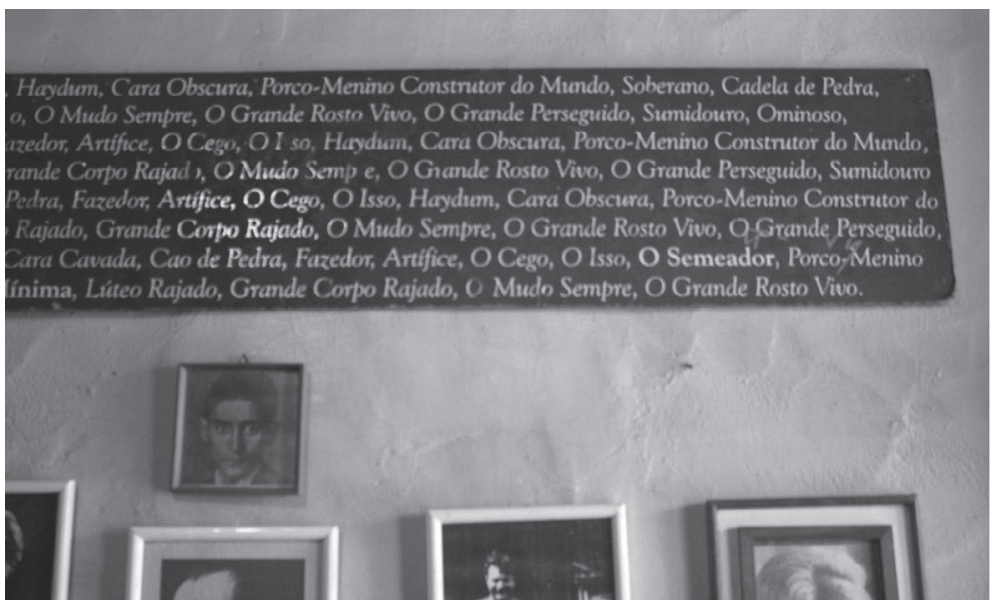

Figura 3. Fotografia por Adam Morris.

Embora "Sem Nome" seja o único que aparece verbatim na placa, os outros nomes giram intimamente em torno dos atributos previamente mencionados, levando-nos a concluir que, em Sobre a tua grande face, tais nomes também se referem ao mesmo Deus. 
Como Hilst declara numa entrevista nos Cadernos de Literatura, sua educação em um colégio religioso impactou profundamente sua escritura:

Caderno: E o que ficou dessa formação religiosa?

Hilda Hilst: Ah, ficou toda a minha literatura. A minha literatura fala basicamente desse inefável, o tempo todo. Mesmo na pornografia, eu insisto nisso. Posso blasfemar muito, mas o meu negócio é com Deus. (Cadernos, 1999, p.37)

Na mesma entrevista, Hilst afirma, inequivocamente, sua procura por Deus:

Caderno: Sua obra, no fundo, procura...

Hilda Hilst: Deus.

Caderno: Ele não significava o Outro, o outro ser humano?

Hilda Hilst: Deus é Deus. O tempo inteiro você vai ver isso no meu trabalho... (Cadernos, 1999, p.37)

O fato de que Deus seja referido por meio de muitos nomes nas Escrituras também permite um paralelo para se compreender "Sem Nome" como uma referência ao mesmo Deus, como Stathis Gourgouris observa em um trecho sobre o mito da Torre de Babel:

[W] hat sustains the regime of the proper name, what justifies the act of naming in the last instance (at least in what is termed the Western tradition), is the most absolute of universal signs, the monadic order itself, the last instance of the Name (which is, of course, unnameable): God (Gourgoris, 2005, p.295).

Sobre a tua grande face compartilha essa busca pelo divino com as outras obras de Hilst. Busca que ocorre através de uma paixão tumultuosa, como já foi mencionado. A freira Janet Ruffing refere-se à união amorosa com Deus em geral como "love mysticism," sendo caracterizado "by feelings of desire, arousal, compassion, and union" 
(Ruffing, 1995, p.21). Enquanto esse tipo de união com Deus não é incomum, o amor descrito no livro de Hilst distingue-se dele, por ser agonizante e também agridoce, pontuado pelos caprichos do "tu" - que é, frequentemente, impiedoso. A vacilação temática entre a união e a desolação, assim como entre outros elementos binários, é estabelecida formalmente pela alternância entre os poemas em português e os kanjis em caligrafia. Ainda mais enigmático é o fato de a caligrafia japonesa ser historicamente associada ao budismo, e, como Ruffing aponta, "every religious tradition of the world, with perhaps only Buddhism as an exception, fosters some form of love mysticism" (1995, p.20). Então, por que Hilst decidiu apresentar seus poemas ao lado dessa forma particular, especialmente quando isso não parece alinhar-se inteiramente com seu projeto e, além do mais, quando seus poemas não contêm nenhuma referência explicitamente japonesa? Para explorar essa questão, deve se analisar primeiramente a história da caligrafia e seu significado cultural.

\section{Caligrafia chinesa e japonesa: um resumo da historia e da filosofia}

Essa história começa por volta do século XIII a.C., quando o sistema da escrita chinesa surgiu e antes do desenvolvimento da mesma caligrafia japonesa. Como notam Fu, Lowry e Yonemura (1986, p.11), "the written language in China is the source of the writing systems of East Asia”. Ainda que o sistema caligráfico centrado no pincel não tenha amadurecido até aproximadamente o século II, com o desenvolvimento do estilo conhecido como "estilo das escribas", os estilos precedentes influenciaram os que se seguiram, especialmente no que diz respeito à estrutura e à estética.

A caligrafia entrelaça-se profundamente com a evolução do sistema da escrita e chegou a se associar com várias outras artes e manifestações culturais conexas. Dado que os chineses usaram os estilos mais antigos da escrita - por exemplo, "escrita de oráculos sobre osso", "escrita sobre bronze" e "estilo do selo", predominantemente 
em adivinhação, cerimoniais e gravação, respectivamente -, a caligrafia está vinculada historicamente a esses domínios da vida cultural. Outros exemplos elogiados da caligrafia têm sido preservados em formas como placas, gravações na pedra ou correspondências entre famílias ou amigos, ou entre o imperador e seus assessores.

A caligrafia é uma habilidade requerida para todos os pintores chineses. Essa ligação íntima entre a caligrafia e a pintura deve-se, por um lado, ao menos parcialmente, à natureza pictográfica de alguns caracteres primordiais, e, por outro, aos compartilhamentos entre as duas artes. Como declara a escritora e artista modernista Ling Su Hua (1954, p.270), "Chinese artists use the same tool for painting and writing”, ou seja, o pincel e a tinta no papel. Posteriormente voltaremos a tratar, neste ensaio, do tema do pincel, mas, agora, buscaremos enfatizar os aspectos técnicos empregados tanto para a escrita quanto para a pintura. Ling (1954, p. 272) afirma que, historicamente, "eminent Chinese painters are also calligraphists. This is not a mere coincidence, but a conscious effort brought about this parallel development". Além de se tornarem especialistas no uso do pincel, é também comum que os pintores escrevam poemas, frases ou a data de término da obra. Como se pode ver, a caligrafia não só compartilha certos aspectos técnicos com a pintura, mas também frequentemente aparece ao lado dela.

Não somente os pintores eram caligrafistas, mas muitos literatos também eram praticantes dessa arte. Subjacente à poesia e à caligrafia está a ressonância entre os conceitos abstratos e a forma material. A poesia chinesa é frequentemente governada por convenções estruturais rígidas como dísticos simétricos ou rimas. $\mathrm{O}$ que distingue os poetas bem-sucedidos são as surpresas que eles podem criar dentro das restrições, usualmente por uma combinação de inovações linguísticas e perspectivas inspiradoras. De modo semelhante, enquanto as interpretações caligráficas do mesmo texto são - num nível básico - performances dos mesmos caracteres, cada iteração é estilizada individualmente, inclusive os estilos da escrita não cursiva. Além do mais, a caligrafia aclamada reconhece-se pelo 神韻, um termo que pode ser traduzido, aproximadamente, por "harmonia espiritual", e que se refere ao "ar" da obra - isto é, ao 
ritmo visual das palavras, que se manifesta em elementos como as pinceladas e o espaçamento que avivam a obra.

A caligrafia não somente é entremeada por outras tradições artísticas, mas também representa uma expressão pela qual pode-se julgar o código moral de uma pessoa. Essa ideia deve-se principalmente a dois aspectos: a estética do caractere escrito e a natureza dos instrumentos utilizados na caligrafia. O historiador da arte Stephen Goldberg descreve o papel do pincel do seguinte modo: "when wet with ink, the tip of the brush forms a perfect point. It is an exceedingly flexible tip completely responsive to the subtlest pressures and movements applied to the brush. For the experienced calligrapher the Chinese brush is an extension of his hand" (Goldberg, 1975, p.1). Ao combinar essa propriedade do pincel com a natureza sensível do papel ou tela extremamente absorventes nos quais se pratica a caligrafia, a maioria dos movimentos internos do escritor - inclusive o menor movimento, seja de qualquer músculo ou oriundo da hesitação e da incerteza reflete-se na escrita. Por isso, o escritor tem de estar certo e totalmente focado durante o esforço de colocar o pincel no papel. Diz-se que se o indivíduo for puro e justo em suas intenções e motivações na vida, isso se refletirá nas pinceladas dos caracteres. Inversamente, as virtudes - como a paciência, a constância e uma mente aberta - que a prática da caligrafia cultiva também formam o caráter pessoal do autor. É provavelmente por essa crença na relação entre a caligrafia e a ética de uma pessoa que, na dinastia Zhou ( 1046-256 a.C.), a caligrafia (juntamente com a arte de classificar os caracteres chineses) formava parte do currículo central na educação geral.

No século V, o Japão adotou o sistema chinês de escrita aliado ao influxo de material cultural, como os clássicos confucianos e obras literárias. Segundo Sadako Ohki, curadora de arte japonesa,

[...] at this time, Japan had but recently achieved national unity and was beginning to develop its cultural traditions. It was the Japanese people's immediate need to master [the three major Chinese scripts that were recently standardized] which were absolutely essential for their diplomatic purposes and for their educational, official, and practical usages within the country." (Ohki, 1975, p.17) 
Além das questões pragmáticas, a difusão do budismo e o consequente aumento da necessidade de shakyo - copiar as sutras - promoveram o estabelecimento da escrita chinesa no Japão. De fato, o ato de copiar as sutras foi integral à evolução da caligrafia japonesa.

Em torno do século VIII, enquanto alguns caracteres chineses permaneciam na língua japonesa pelo som ou significado, os japoneses já haviam desenvolvido seu próprio sistema de escrita ao abreviar a escrita chinesa em símbolos fonéticos conhecidos como kana (仮名). A estrutura mais simples e fluida da kana cursiva era "particularly suited to writing the short Japanese waka (or tanka) poem of thirty-one syllables composed in lines of five or seven syllables", permitindo ao caligrafista "considerable compositional freedom" (Fu; Lowry; Yonemura, 1986, p.62-3). A escrita de kana logo se desenvolveu em um ramo caligráfico singularmente japonês. Desse modo, a caligrafia no Japão é - como na China - uma arte relacionada a outras tradições estéticas e inspira produções em várias esferas culturais.

Ainda que a caligrafia japonesa tenha criado um legado único e tenha desenvolvido filosofias e estilos distintos, as obras chinesas continuam sendo estudadas e permanecem relevantes nas discussões de caligrafia como gênero. Como Ohki (1975, p.17) enfatiza, " $t$ ] hroughout the history of calligraphy in Japan [...] a cycle of learning and absorbing Chinese prototypes, then achieving Japan's own individualistic aspect, was repeated". Essa vicissitude mostra que, enquanto as duas tradições devem ser avaliadas perante suas próprias histórias, é importante considerar a trajetória geral que possibilite um visão mais ampla acerca da caligrafia japonesa, especialmente com o propósito de se entender o uso dos kanjis no livro de Hilst.

\section{Traduzir ou não traduzir}

Antes de avançarmos com a análise do livro, é útil retomar algumas questões sobre as quais este ensaio se propõe refletir. As duas questões principais são: 1) ponderar sobre a decisão de Hilst 
de apresentar seus poemas juntamente com os kanjis caligráficos de Wakabayashi, e 2) compreender a ausência de sua tradução, que atua como uma barreira para o típico leitor de português. Ademais, ainda que Hilst seja a autora principal do livro, a sequência poética é prefaciada e concluída com um caractere, que sublinha a integralidade dos caracteres escritos nos poemas, refutando a hipótese de que eles serviriam tão somente a um propósito decorativo. Contrariando essa hipótese, propomos a indagação sobre se os caracteres, em certos níveis, acabariam por conduzir os próprios poemas. Essas questões guiarão nossas análises ao longo do restante do ensaio.

Buscaremos recorrer agora à analogia visual dos cartões-relâmpagos, já que essa comparação permite focalizar a justaposição de dois meios muito distintos, bem como a questão da ausência de tradução. Se as páginas de Sobre a tua grande face fossem cartões-relâmpagos, o típico leitor brasileiro, que não fala japonês, provavelmente esperaria que houvesse uma tradução em português ao lado inverso do kanji, talvez com uma frase exemplar ilustrando seu uso. A tradução, nesse caso, seria uma ponte entre as duas línguas e facilitaria a transição entre elas. A decisão por não traduzir, então, equivale a rejeitar essa ponte. Se a tradução torna o texto mais acessível, o que poderia ser logrado com sua ausência? Ainda que se considere a decisão pela não tradução, valeria a pena também explorar uma linha de pensamento que poderia representar um passo na direção oposta ou, um passo mais adiante, poderíamos considerar os poemas e os caracteres como uma tradução interna mútua?

Primeiramente, pode-se considerar o texto como não oferecendo a tradução dos kanjis. Ao se falar sobre a tradução, identificam-se maneiras diferentes de ler, dependendo da proficiência do leitor nas duas línguas. Pode-se entender a tradução como "rendering a text written in one language understandable in another language", no qual " a meaning generally [could be] held to transcend individual languages the way universality transcends particularity" (Weber, 2005, p.65). Tendo em vista os aspectos visuais, os significados dos kanjis serão os seguintes, de acordo com a ordem na qual aparecem: 


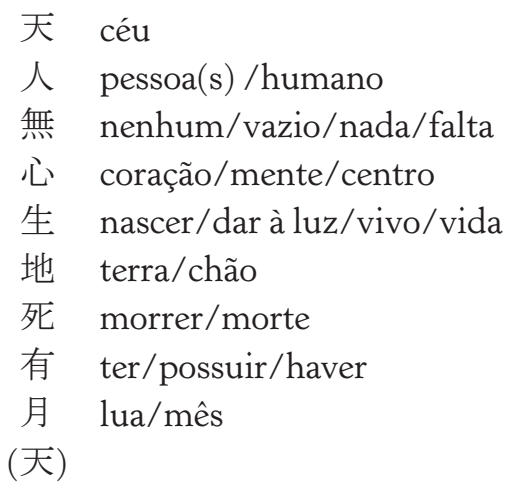

Nesses kanji são representados alguns dos conceitos mais fundamentais sobre o entendimento acerca do mundo. Podem-se identificar dicotomias convencionais, como vida/morte, faltar/haver. Contudo, alguns dos conceitos são mais difíceis de serem situados um em relação ao outro. Por exemplo, seria o céu (num sentido ampliado, de divino) o oposto da terra ou do humano? O que seria o oposto da lua? Como se evidencia, o fato de alguns conceitos resistirem à classificação binária perturba os outros binários mais "óbvios" ou "aceitos" da lista. Dessa maneira, o leitor é instigado a relacionar os conceitos de uma forma que escapa às dicotomias convencionais.

A relação de opostos que os kanji traduzidos ilustram também se manifesta nos poemas. Anteriormente, identificou-se o poder desigual entre o sujeito lírico e seu objeto de desejo, estabelecendo-se o dominante e o dócil. Essa relação manifesta-se ainda mais claramente no poema associado com o caractere 生, quando o eu lírico se compara a (ou renasce, no verso, como) uma égua, a procura frenética de "Sem nome":

Ando em grandes vaguezas, açoitando os ares

Relinchando sombras, carreando o nada.

Os que me veem me gritam: como tem passado

a aldeã de sua alteza? E há chacotas e risos. (Hilst, 1986) 
A futilidade da busca empreendida pela locutora, sua subordinação tão publicamente reconhecida e a chacota consequente que experimenta não bastam para contrapor a atração pela "Grande Face," a qual só pode se articular por meio de substantivos vagos ("sons", "cicios", "um labiar de sabores, um sem nome de passos") e de analogias ("Como se águas pequenas desaguassem/Num pomar de abios. Como se eu mesma/Flutuasse, cativa, ofélica, sobre a tua Grande Face"). O ato de contornar uma descrição concreta da sedução do destinatário do poema com nomes vagos e comparações sugestivas, mas enigmáticas, aponta a dificuldade de articular esse amor devido a sua índole espinhosa. O que torna tão difícil falar sobre a relação nos termos mais simples e explicativos - e, por outro lado, tão apto para a flexibilidade exploratória da poesia - é precisamente essa desmontagem das dicotomias, mais proeminentemente entre "a realidade e as suas outras". Esse verso se refere a sonhos, alucinações, devaneios, e assim por diante, sendo esses geralmente fundados no real, mas, na obra de Hilst, eles nem sempre se opõem à suposta realidade, e funcionam muito mais como as suas alternâncias. Por exemplo, no segundo poema do livro, Hilst escreve:

\section{Então direi}

O que se coleia a mim na intimidade, e atravessa os vaus

Da fantasia. Deito-me pensada de bromélias vivas

E me recrio corpórea e incandescente (Hilst, 1986)

Mais adiante, no contexto dessa visão, a locutora constrói um corpo incandescente no qual ela documenta, pela primeira vez, a consumação da relação: "Arquiteta de mim, me construo à imagem das tuas Casas/E te adentras em carne e moradia". "Casas" aqui são catedrais mencionadas no mesmo poema. O sujeito lírico então se transforma em um espaço sagrado no prazer carnal, rompendo ainda mais a divisão entre as noções tradicionalmente opostas de santidade e perversidade. Além disso, a fusão dos conceitos discretos também ocorre no nível do espaço imaginado do texto e do espaço que ocupa o leitor, identificado como o real. Observa-se essa ruptura com a realidade no primeiro poema do livro (citado previa- 
mente), no qual a locutora pede por "nenhum cão", já que os cães ofereceriam alguma consolação para seu anelo. O leitor que havia se familiarizado com a vida de Hilst reconheceria seu amor pelo animal: a autora mantinha um grupo grande deles na Casa do Sol. ${ }^{1}$

Outra questão que vale a pena explorar nesse primeiro poema é o poder de criação. Como a relação amorosa é uma procura por Deus, seria apropriado traçar um paralelo com o Gênesis, um dos momentos originais de criação na literatura ocidental. Como observa Samuel Weber, "creation, in the biblical account, operates above all through a series of dichotomies, beginning with the distinction between unbound space ('heaven') and limited place ('earth') [...][H] eaven and earth [were] defined through a series of oppositions that progressively differentiated the place called earth" (Weber, 2005, p.67-8). Contudo, o poema acima sublinha não a criação de Deus, mas a que está associada ao caractere 人, que denota um humano com o poder de se reconstruir, exatamente o que a locutora faz. Essa asserção de vontade e poder criativo estão conectados com o motivo do autor e o texto no livro, mencionado, no início, com a figura de "tu" como um brejeiro escoliasta. A leveza com a qual o "tu" trata suas criações textuais sugere a confiança que ele tem em seu poder criativo, refletindo a atitude temerária que o "tu" estabelece em sua relação com o sujeito lírico. Entretanto, essa dinâmica de poder complica-se ao final do penúltimo poema do livro:

1 Adam Morris, um dos tradutores de Hilst, oferece o seguinte relato sobre a conexão extraordinária que Hilst tinha com os cachorros: "Her dogs accompanied her at the dinner table, watched over her while she wrote, and crowded around her as she moved through the Casa do Sol. In nearly every photo of Hilst, there are dogs and more dogs. Though they were extravagantly numerous, she always knew all of their names. Hilst disdained those who disliked dogs, and the first question she asked visitors and new acquaintances brought to her house by friends - before proceeding to ask them about their zodiac sign and the details of their sex life - was whether or not they liked dogs. Anecdotes about Hilst's strange ability to communicate with dogs abound. One resident of the Casa do Sol recalled the way her dogs rushed to break Hilst's fall when she fainted upon hearing the telephone ring one day, having correctly intuited that someone was calling to tell her a friend had succumbed to AIDS. Though she kept hundreds of dogs throughout her life, her diary entries record the deep pain she felt when any of them died. When euthanasia was required, Hilst sometimes administered the injection herself' (Morris, 2014, p.xxi-xxii). 
Em minhas muitas vidas hei de te perseguir.

Em sucessivas mortes hei de chamar este teu ser sem nome

Ainda que por fadiga ou plenitude, destruas o poeta

Destruindo o Homem. (Hilst, 1986)

E também no último poema:

E destes versos, e da minha própria exuberância

E excesso, há de ficar em ti o mais sombroso.

Dirás: que instante de dor e intelecto

Quando sonhei os poetas na Terra. Carne e poeira

O perecível, exsudando centelha. (Hilst, 1986)

Nas duas estrofes, o sujeito lírico menciona a facilidade com que Deus destrói o humano, presumidamente uma criação suja. No entanto, a especificidade da figura do poeta evoca a locutora, unida, ao menos em parte, com a mesma Hilst, como autora do texto que contém o Deus que ela procura. Há, assim, o efeito de uma dinâmica encaixada na qual o Deus e o humano criam-se mutuamente nos espaços intra e extratextuais que o leitor deve desvelar em camadas. Portanto, poder acessar os significados dos kanjis permite que o leitor engaje-se com o texto como uma exploração do ato de criação, por parte do humano, e das forças divinas por meio da lente de um Gênesis revisado. ${ }^{2}$ Essa revisão não perpetua as dicotomias como o Gênesis original; ao contrário, as confunde. Esse conceito também esté presente quando consideram-se as mudanças na percepção e interpretação do leitor, motivadas pela tradução dos kanjis: o que antes eram duas línguas polarizadas agora trabalha sinergicamente para produzir leituras mútuas altamente matizadas. Mas a pergunta que se suscita é essa: se os significados dos kanjis facilitam essa interpretação, por que não revelá-los?

2 Se estudarmos o Gênesis, veremos uma fonte possível que pode ter inspirado algumas das ideias de Hilst sobre Deus, manifestadas em seus nomes para ele: "No princípio criou Deus o céu e a terra. E a terra era sem forma e vazia: e havia trevas sobre a face do abismo...” (A Bíblia Sagrada, Gênesis 1, grifos meus). 
Uma resposta possível seria: se os significados fossem explicitados como parte do texto, não haveria a necessidade de incluir os kanjis como tais. Hilst poderia ter escolhido prefaciar cada poema com palavras em português, como "Lua" e "Morte." Certamente, a camada visual que os kanjis agregam estaria perdida, e, além disso, como a tradução transmitiria as dicotomias presentes nos significados dos kanjis, o leitor seria preparado para interpretar o livro como uma reescrita do mito de criação tal qual apresenta o livro de Gênesis.

Para encontrar uma resposta à questão do formato do livro, este ensaio propõe pensar uma perspectiva alternativa de tradução, a qual se preocupa não com o suposto significado universal por trás das palavras, mas com o próprio material dessas palavras. A ideia de que existe um significado que transcende a distinção dos idiomas diferentes reflete o que Derrida chama de "teologia do texto": a crença em que "the text is an ideal, spiritual substance, a Platonic form of which the material thing [eg. books] is merely a 'copy'. The physical object is simply a medium" (Aichele, 1993). Aceitar o modelo que acabamos de apresentar, que concebe o poema e o caractere como uma tradução mútua, significa ler o projeto de Hilst e Wakabayashi como uma refutação da teologia do texto, focalizando a iteração singular e material de cada palavra. Em uma análise desse tipo, vale a pena considerar a ideia de Weber na seguinte citação:

[...] translation always involves not merely the movement from one language to another, but from one instance - a text already existing in one language - to another, that does not previously exist, but that is brought into being in the other language. The tension between the generality of the language systems and the singularity of the individual texts is reflected, but also concealed, by the ambiguity of the very word "translation" itself, which designates both a general process, involving a change of place, and a singular result of that process: translating in general, and (a) translation in particular. The tension between the general process and the individual product tends to be obscured by an attitude that regards translation as an instrument in the service of the "communication" of the meaning or a message. This attitude 
privileges the generality of the process at the expense of its singularity. (Weber, 2005, p.66)

O que Weber aponta é a particularidade de cada manifestação da língua. Enquanto é verdade que normalmente considera-se a mesma palavra como correspondente a várias traduções "aceitáveis" na língua de chegada, esse ponto de vista arrisca aplainar o idioma em unidades comensuráveis e intercambiáveis e, como resultado, limitaria seu potencial expressivo. Portanto, a língua deve ser pensada em instâncias, para as quais se deve levar em conta tanto o contexto quanto as circunstâncias de enunciação de cada enunciado.

No caso dos caracteres em Sobre a tua grande face, a ideia de Weber é particularmente significante porque a singularidade de suas instâncias precisa ser analisada em ao menos três níveis. Em primeiro lugar, semanticamente, tal como foi mostrado, cada caractere pode ser usado em distintas classes gramaticais ou ter várias definições. Em segundo lugar, um aspecto desses caracteres que não é imediatamente visível, mas igualmente importante, é a dimensão aural. Como a maioria dos kanjis, cada um desses caracteres tem ao menos duas pronúncias: a onyomi (音読み) e a kunyomi (訓読み). A onyomi é a pronúncia que mais se parece com o som do caractere em chinês, utilizada nos contextos mais literários, enquanto a kunyomi baseia-se na pronúncia japonesa nativa que mais se aproxima do significado do caractere chinês importado. Dependendo da história e do uso do kanji, pode haver mais de dois tipos de pronúncia. Se considerarmos a materialidade do caractere em sua totalidade, será necessário incluir também suas propriedades sonoras. Em terceiro lugar, no que diz respeito ao aspecto visual, como previamente mencionado, cada execução do caractere caligráfico (mesmo que seja feita pelo mesmo autor) é considerada única, já que singularmente reflete a combinação entre técnica e affect no momento da criação. Em concordância com o crítico cultural Eric Shouse, que segue as ideias de Brian Massumi, affect define-se como " $a$ non-conscious experience of intensity; it is a moment of unformed and unstructured potential"; $\mathrm{e}$ "is always prior to and/or outside of 
consciousness" that "cannot be fully captured in language" (n.p.). ${ }^{3}$ Devido à natureza dos instrumentos e métodos usados, a caligrafia comunica affect em certos níveis, como se evidencia na seguinte descrição de Goldberg:

The execution of the character is itself a communication in which the movements and pressures applied to the brush make reference to the disposition or inner state of the calligrapher and his relationship to what is written. For this reason Chinese calligraphy may be defined as the art of gestural expression. The significance of this kind of expression lies in the primacy of gesture as that mode of intentional behavior which originates on the pre-verbal level of the body experience and thus is most truly expressive of one's state of being. (Goldberg, 2014, p.1)

Portanto, o fato de que os caracteres são kanjis e escritos em caligrafia eleva significativamente os desafios impostos a sua tradução. As variáveis e propriedades semânticas, aurais, visuais e afetivas constituem um meio sofisticado que demanda uma legibilidade nova e complexa.

Para contemplar a complexidade desses vários aspectos é importante pensar como a poesia pode ser considerada uma tradução adequada das instâncias caligráficas do idioma apresentadas como arte visual. Nesse sentido, a crítica literária Elissa Marder ressalta o seguinte acerca do ensaio "Freud and the Scene of Writing", de Derrida: "The materiality of a word cannot be translated or carried over into another language. Materiality is precisely that which translation relinquishes. To relinquish materiality: such is the driving force of translation. And when that materiality is reinstated, translation becomes poetry" (Derrida, 1972, apud Marder, 2013, p.1). Sob o risco de tomar a palavra "poetry" em um sentido literal demais, o comentário de Derrida exibe, em primeiro plano, o "corpo verbal” da palavra - le

3 Shouse justapõe "affect" com "feeling" e "emotion", as quais define respectivamente como "a sensation that has been checked against previous experiences and labelled" e "the projection/display of a feeling". Esclarece ainda mais ao declarar que as emoções podem ser ou genuínas ou dissimuladas, podendo não corresponder necessariamente aos "feelings" do sujeito. 
corps verbal, o que o tradutor Alan Bass interpreta como "materiality" (Marder, 2013) - ante uma inclinação prevalente que tende demasiadamente ao significado às custas do meio. Ver os poemas de Hilst como traduções dos caracteres de Wakabayashi é restabelecer ao menos uma possibilidade do corpo verbal em português.

Pode-se observar um exemplo do livro com o objetivo de se examinar a atenção dada à visceralidade, que se manifesta na caligrafia tanto como no poema, e intensifica - como mencionado anteriormente - contato entre as dicotomias. Vejamos a primeira metade do penúltimo poema, associado ao caractere "lua":

De montanhas e barcas nada sei.

Mas sei a trajetória de uma altura

E certa fundura de águas

E há de me levar a ti uma das duas.

De ares e asas não percebo nada.

Mas atravesso abismos e um vazio de avessos

Para tocar a luz do teu começo.

Das pedras só conheço as ágatas.

Mas arranco do xisto as esmeraldas

Se me disseres que é o verde a dádiva

Que responde as perguntas da Ilusão.

E posso me ferir no gelo das espadas

Se me quiseres banhada de vermelho. (Hilst, 1986)

Vê-se que o poema toma lugar nos interstícios das dicotomias, como o conhecido e o desconhecido, a regressão e o começo, o concreto e a ilusão. Certas condições e limitações dadas - como o instinto de autopreservação que evita a dor e o dano - refutam-se e são compensadas pela vontade de tornar o corpo maleável pelo amor. Além do mais, como em outros poemas na sequência, o lírico aqui é carregado de imagens - mas é conduzido pela instabilidade de cada imagem, e não por sua durabilidade, como se poderia esperar. O que acompanha esse imaginário tremeluzente e sucessivo é o impulso sônico: o poema é guiado por uma musicalidade aguda, 
incorporada nas transformações de, por exemplo, "atravesso" a "abismos" a "avessos", "esmeralda" a "espadas", "disseres" a "gelo". Uma fluidez similar e a ambiguidade do corpo também se apresentam no kanji associado ao poema, 月:

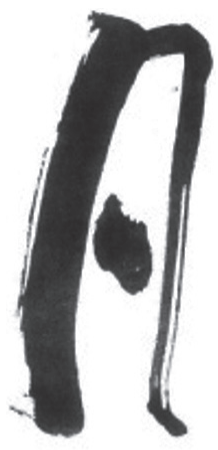

Walohingliti

Figura 4

Ao observarmos a versão impressa do caractere, podemos notar que as duas pinceladas horizontais originais são apresentadas como uma só na versão caligráfica. Essa decisão estética importa especialmente porque essa execução particular de "lua" lembra sua encarnação nas escritas mais antigas, a qual, por sua vez, se aproxima das versões mais modernas do caractere para "sol", como ilustrado na Figura 5:

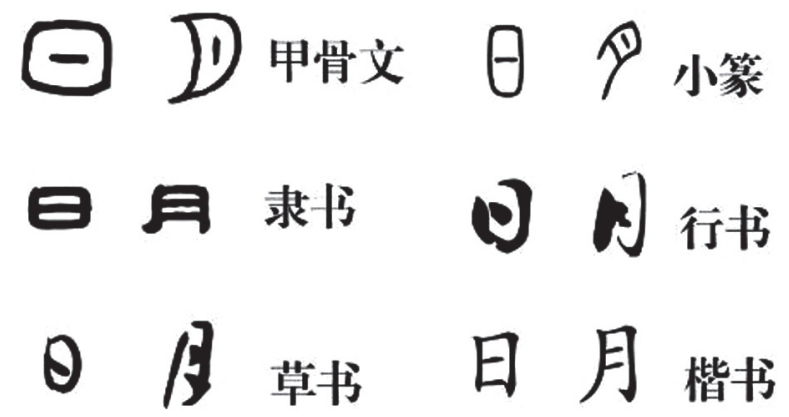

Figura 5 
Justapondo-se a evolução dos caracteres para "sol" e "lua" nos vários estilos de escrita, pode-se apreciar a "lua" de Wakabayashi como um grafismo ambíguo que contém os dois conceitos, um caractere cujo corpo verbal desafia uma leitura - e, portanto, uma tradução - clara e definitiva, ecoando a dinâmica fluida do corpo poético de Hilst.

A interpretação da poesia e da caligrafia como traduções mútuas, ainda que pouco convencional, é coerente com o que o linguista Clive Scott chama de tradução "sinestética”. Para Scott (2011, p.40), o "intermedial" é um termo insatisfatório, porque deixa os meios artísticos intactos. O estudioso favorece o termo "synaesthetic", que reflete "a phenomenological assumption that we perceive the universe with the totality of our bodies with the concerted operation of all our senses" (Scott, 2011, p.39). Ao referir-se a uma tradução sinestética, exige um entendimento da tradução como mudar "one medium out of itself into multi-sensory, or cross-sensory, consciousness; put another way, it is the translation of one medium back into whole-body experience" (Scott, 2011, p.40). Aqui reside, de novo, o problema da singularidade versus diversidade. Scott postula a tradução de uma maneira que reflete uma concepção paralela à intervenção de Weber, ressaltando que o ato de traduzir é mudar de instância a instância e não só de um idioma a outro, como muitos creem. De modo similar, em Sobre a tua grande face, Hilst e Wakabayashi reúnem o português e o japonês de uma maneira que instiga o leitor a ir além da unidade aparente de cada idioma, que, à primeira vista, parece se opor a suas diferenças. ${ }^{4}$ A princípio, a aparência limpa e minimalista do kanji

4 Uma questão que permanece é por que razão Hilst teria decidido trabalhar com o japonês em vez de outros idiomas e tradições artísticas. Ainda que não se possa aceitar completamente os motivos da autora, é possível considerar alguns fatores. Primeiramente, pode ser que Hilst tenha querido marcar sua literatura com um afastamento em relação aos poderes eurocêntricos dominantes valorizados no mundo intelectual brasileiro. Numa entrevista, a autora questiona o favorecimento, desprovido de senso crítico, que pratica em relação a outros idiomas europeus em detrimento do português: "Você não pode pen- 
em cada página é contrabalanceada pela história intensa e complexa de amor, a qual é simultaneamente uma narrativa de poder e criação relatada em um português vívido, polissêmico e neologístico. Contudo, uma análise detalhada dessa colaboração revela corolários inesperados, tanto na forma quanto no conteúdo dos dois idiomas e meios de expressão, fazendo que se estabeleçam traduções mútuas e plausíveis. Por outro lado, a incomensurabilidade entre os dois porquanto há que se reconhecer que a "tradução sinestética" é uma perspectiva bastante liberal, que não se submete ao que usualmente se concebe com o termo "tradução" - serve à preocupação temática de Hilst de uma maneira estranhamente apropriada, ao ecoar e dobrar a energia de seus poemas: todo o espaço e toda a ausência entre ela e o desejado. O livro então perpetua as forças oscilantes entre as dicotomias, colocando-as em contato, mas sem obliterá-las, possibilitando ressonâncias crescentemente matizadas envolvendo aquilo que, à primeira vista, parecia contraditório ou sem vínculos. Talvez esse poder de criação contínua de uma estética surpreendentemente maximalista seja parte do divino que Hilst tem, na verdade, logrado alcançar.

sar em português. É bom pensar em inglês, em alemão, as pessoas aceitam. Em português, você... pensar é algo horrível, então os editores te odeiam" ("Hilda Hilst TV Cultura”). Ao simultaneamente trabalhar seu português com ocorrências textuais caleidoscópicos e vibrantes, Hilst claramente expressa sua aversão a essa tendência no mundo editorial. Outra possibilidade vem do fato de que seu editor principal, Massao Ohno, era japonês, o que pode tê-la posto em contato com a cultura japonesa de modo mais significativo do que com outras culturas. A terceira possibilidade não é diretamente relacionada com a própria Hilst, mas continua sendo um fator provável. Como assinala Cristina Rocha, especialista em estudos japoneses, o fato de que, por muito tempo, a percepção brasileira acerca do Japão foi filtrada pelas perspectivas francesas é reflexo da desvalorização do capital cultural que possuem os imigrantes japoneses, o que é um resultado direto da falta de capital financeiro (204-5). Ao colaborar com um artista nipo-brasileiro e trabalhar com uma tradição artística proeminente e japonesa, Hilst abertamente refuta a atitude depreciativa arraigada no racismo histórico. 


\section{Referências bibliográficas}

A BÍBLIA SAGRADA. Disponível em: <http://www.wordproject.org/ bibles/po/index.htm>. Acesso em: 10 set. 2014.

AICHELE, G. Reading Beyond Meaning. Postmodern Culture, v.3, n.3, maio 1993. Disponível em: <http://pmc.iath.virginia.edu/text-only/ issue. 593/aichele.593>. Acesso em: 10 set. 2014.

CADERNOS de Literatura Brasileira - Hilda Hilst. São Paulo: Instituto Moreira Salles, n. 8, 1999.

FU, S.; LOWRY, G. D.; YONEMURA, A. (Eds.) From Concept to Context: Approaches to Asian and Islamic Calligraphy. Washington, D.C.: Freer Gallery of Art, Smithsonian Institution, 1986.

GOLDBERG, S. The Primacy of Gesture: An Introduction to the Art of Chinese Calligraphy. In: Calligraphy of China and Japan: The Grand Tradition. Ann Arbor: University of Michigan Museum of Art, 1975, p.1-7. Print.

GOURGOURIS, S. DeLillo in Greece Eluding the Name. Nation, Language, and the Ethics of Translation. Ed. Sandra Bermann and Michael Wood. Princeton: Princeton University Press, 2005, p.65-78.

HILST, H. Sobre a tua Grande Face. São Paulo: Massao Ohno Editor, 1986.

With My Dog Eyes. Trans. Adam Morris. Brooklyn, NY: Melville House, 2014.

LING, S. H. On the Relation Between Chinese Painting and Calligraphy. East and West, v.4, n.4, jan. 1954, p.269-77.

OHKI, S. Early Japanese Calligraphy. Calligraphy of China and Japan: The Grand Tradition. Ann Arbor: University of Michigan Museum of Art, 1975. p.17-23.

ROCHA, C. Zen in Brazil: Cannibalizing Orientalist Flows. Orientalism and Identity in Latin America: Fashioning Self and Other from the (post)colonial Margin. Tucson: University of Arizona, 2013, p.200-16.

RUFFING, J. Encountering Love Mysticism. Presence 1.1, 1995, p.20-33.

SCOTT, C. From the Intermedial to the Synaesthetic: Literary Translation as Centrifugal Practice. Comparative Critical Studies, 8.1, 2011. p.39-59.

SHOUSE, E. Feeling, Emotion, Affect. M/C Journal, 8.6, 2005.

WEBER, S. A Touch of Translation: On Walter Benjamin's "Task of the Translator". Nation, Language, and the Ethics of Translation. Ed. Sandra Bermann e Michael Wood. Princeton: Princeton University Press, 2005, p.65-78. 


\title{
"I'M COMING OUT IN ENGLISH": EM TORNO DA TRADUÇÃO DE CONTOS D'ESCÁRNIO. TEXTOS GROTESCOS
}

\author{
Julia Powers \\ Livia Drummond
}

Recentemente, em livro organizado pelo pesquisador Alcir Pécora, dedicado a pensar aspectos da obra de Hilda Hilst, encontramos a seguinte sentença servindo de título: Por que ler Hilda Hilst, frase que, construída de modo perspicaz sem ponto final ou de interrogação que a encerre, confere ao título um tom ambíguo que, oscilando entre a interrogação e a afirmação, leva-nos a adentrar o universo hilstiano. No mesmo tom, os artigos ali reunidos trazem possíveis alternativas que justificam e, em certa medida, respondem ao aparente questionamento que intitula o volume. Partindo dessa perspectiva, redimensionaremos a frase de Pécora, formulando-a da seguinte maneira: Por que traduzir Hilda Hilst?

No esforço de pensar essa questão, buscaremos, neste trabalho, apresentar um breve panorama da obra hilstiana a partir dos traços encontrados no livro Contos d'escárnio. Textos grotescos, na tentativa de delinear características que definam sua escrita de um modo geral. Em seguida, apontaremos possíveis saídas para essa que também seria uma frase dúbia - Por que traduzir Hilda Hilst-, destacando os principais problemas encontrados pelas autoras do presente ensaio quando da tradução de Contos d'escárnio. Textos grotescos. Por fim, demonstraremos os recursos tradutórios utilizados para alcançar tão abastado e criativo vocabulário pornográfico, 
considerando as complicações apresentadas pelos comentários que o próprio romance oferece sobre as questões de tradução. "Vou sair em inglês" (Hilst, 2002, p.114), declara Crasso em tom premonitório no final do romance. Mais de duas décadas depois, seu sonho delirante, e talvez sarcástico, de "sair" em inglês está se tornando realidade, apesar dos vários obstáculos encontrados na tarefa de tradução.

Como apresentar uma autora como Hilda Hilst, sobretudo para um público anglófono, em parte ignorante de sua obra? A princípio, sabemos como não apresentá-la, ou seja, não incorreremos no erro tão comum, por décadas repetido pela crítica, que se refere a ela recorrendo a sua figura de rara beleza e personalidade meteórica. Tampouco recorreremos a sua figura de mito pop que agitava o meio boêmio-intelectual brasileiro de meados do século XX, em que transitava entre os astros de Hollywood, tentando a todo custo arrancar-lhes beijos apaixonados, bem como não nos atreveremos a retratá-la como uma asceta que se retirou da vida mundana para dedicar-se ao trabalho místico-intelectual. Percebemos que, em todas essas formas de apresentação, "a imagem pública da artista como tipo excêntrico predominou sobre o conhecimento da obra" (Pécora, 2010, p.8). Esses perfis são evocados com muita frequência quando se pretende falar ou escrever sobre Hilda Hilst e sua obra. No entanto, observamos que existe atualmente um grande esforço por parte de críticos e estudiosos da literatura em reparar essa desastrosa forma de abordagem e deslocar o foco de tratamento dado à autora. Privilegiando as análises de seus textos em vez da sua figura mítica, já podemos encontrar, mesmo em sites da internet, menções que a referenciam como "uma das maiores escritoras da língua portuguesa do século XX”.

Tais perfis são emblemáticos, pois ajudam a compor imagens públicas da autora que podem ou não ser reiteradas; para tanto, basta confrontar esses jargões descritivos com textos, cartas e entrevistas da própria Hilda Hilst. Esta é uma opção interessante, caso o pesquisador/tradutor pretenda enveredar por uma reflexão sobre 
o conceito de postura autoral pensado por Jerôme Meizoz, pois nos reporta dados importantes sobre a postura que será colocada em jogo pela autora, seja ela consciente ou não, em suas aparições públicas, em seus posicionamentos político/intelectuais, assim como em sua obra. Meizoz (2007) chama de posturas autorais "essas modalidades de autocriação" exercitadas pelos escritores modernos/ contemporâneos que colocam em cena tanto aquela " "maneira de ser de um escritor' visível nas diversas posições, hábitos e posturas de um autor", como aquelas que aparecem na "dimensão retórica (textual) e contextual”. Assim, a postura autoral de Hilda Hilst, sua maneira de se portar no campo literário, talvez tenha sido construída astuciosamente como forma de atrair a atenção do público para sua obra.

Feitas as devidas considerações, optaremos aqui por tratá-la como uma das poucas grandes escritoras brasileiras do século XX cuja obra extremamente rica e singular, apesar de continuar um tanto quanto desconhecida, é capaz de despertar, tanto entre os leitores "especializados" quanto entre os leitores "não especializados", sentimentos e críticas das mais odiosas às mais elogiosas.

A obra ficcional de H. H. gira em torno de temas que, no nível discursivo, evidenciam alguns traços que a definem como autora, quais sejam, suas reflexões sobre experiências místicas e metafísicas, seu violento humor negro, sua ironia cortante, seu laborioso exercício de estilo, seu erotismo paródico, cru, obsceno e divertido (para alguns). Sua prosa revela uma escrita angustiante e obscena que transgride não apenas na forma de seus escritos, mas também de seu conteúdo. Angustiante por evidenciar o vazio intangível do não saber e a quase impossibilidade de transformar em linguagem sensações tão ambíguas, aterradoras; obscena no sentido trazido por Sonia Purceno (2010, p.64), para quem:

Hilda Hilst está no encalço dos limites, que sabe insustentáveis, do obsceno - tratado aqui fundamentalmente como aquilo que entra em cena de forma transgressiva, provocando a imaginação e a pudicícia do escritor e do leitor. 
Como podemos observar quando da leitura de seus textos ficcionais, Hilda Hilst coloca em cena o que, em certa medida, sempre esteve fora dela, a exemplo de reflexões inusitadas sobre literatura, cânone literário, mercado editorial, processo de criação, pornografia etc. Assim, não é estranho nos depararmos com personagens como Crasso, narrador-personagem e autor fictício desses Contos d'escárnio, afirmando categoricamente que Ezra Pound é um "cara repelente. Um engodo. Invenção de letrados pedantescos” (Hilst, 2002, p.20), ou destilando sua amarga crítica ao mercado literário, dizendo: "resolvi escrever esse livro porque ao longo da minha vida tenho lido tanto lixo que resolvi escrever o meu" (Hilst, 2002, p.14), ou, ainda, explicitando o "penoso" (Hilst, 2002, p.32) trabalho do escritor, ao refletir sobre a melhor maneira de formular a seguinte sentença: "A primeira vez que eu 'a fodi' (ou que 'fodi-a' ou que 'fui fodê-la', é melhor?)” (Hilst, 2002, p.16).

Se existe certa dificuldade em dar conta do conjunto da prosa hilstiana devido ao seu caráter hermético, caótico, híbrido, descontínuo e de um vocabulário que oscila esquizofrenicamente entre a mais alta erudição e o mais vulgar linguajar de bordel, pode-se imaginar o quão dificultoso é tomar por tarefa a tradução de alguma de suas obras, pois nelas é praticado, de forma sistemática, um vertiginoso exercício de estilo no qual diversos gêneros textuais estão dentro de um mesmo espaço narrativo, explorando o jogo ambíguo da linguagem e diluindo de forma irreversível as fronteiras entre a "boa" e a "má" literatura. Traduzir obras de Hilda Hilst para outro idioma constitui um trabalho um tanto quanto complexo, e tal complexidade aumenta quando a obra traduzida compõe o quadro da tetralogia obscena - nesse caso, a tarefa de recriar em outra língua um dos mais amplos vocabulários pornográficos da literatura brasileira, assim como formas narrativas que parodiam tanto o estilo do best-seller quanto o do romance literário, torna-se uma tarefa alquímica.

Apesar de compreendermos que sua produção em prosa esteja sempre tratando de temas recorrentes, e que os doze textos que a compõem funcionam como um laboratório literário de experimen- 
tação estilística, escolhemos traduir o livro Contos d'escárnio. Textos grotescos por entendermos que esse trabalho sintetiza um dos grandes momentos de sua produção, pois enfatiza seu marcante tom irônico, assim como desafia os próprios limites do cânone literário ao colocar em cena temas e vocabulário "desviantes" e paródicos banidos da "alta" literatura.

Dessa maneira, outro problema se coloca: como apresentar aos editores norte-americanos a ironia da escritora Hilda Hilst e de seus Contos d'escárnio dentro do contexto da literatura brasileira? Se a tetralogia obscena representa uma guinada provocativa em sua produção, é possível que essa provocação engenhosa seja mal interpretada. Felizmente, segundo as palavras de um editor nova-iorquino, Hilda Hilst está se tornando "uma febre contagiosa" nos EUA prova disso são as recentes publicações das traduções de textos como A obscena senhora D, lançado em inglês, em 2012; de fragmentos de textos em prosa e de poemas que vêm proliferando em revistas especializadas e das traduções que estão por vir, como é o caso dos textos Com meus olhos de cão e Cartas de um sedutor. Talvez essa febre sirva para preparar os (ainda poucos) leitores da obra hilstiana nos EUA para o singular escárnio e a sofisticada autocrítica de seus Textos grotescos.

Contos d'escárnio. Textos Grotescos escancara questões pouco tematizadas na literatura brasileira, abordando explicitamente, entre outras coisas: a complexa relação entre escritor e mercado editorial; a problematização da qualidade da literatura produzida e publicada pela indústria do livro; indagações metafísicas e práticas sexuais divergentes que constituem parte fundamental das experiências das personagens. Suas propostas eróticas, metafísicas e crítico/ filosóficas visam o questionamento das posições estabelecidas dos sujeitos/personagens na trama, descentrando e arruinando a segurança castradora de seus cotidianos insossos.

Como bem assinalou Pécora (2002), se tentássemos resumir o enredo dessa prosa memorialística absurda, não teríamos muito a dizer: Crasso, homem sexagenário, entediado com a vida, com o sexo, com todo o lixo literário publicado pelo voraz mercado edi- 
torial, resolve tornar real um desejo alimentado por toda a vida, o desejo de tornar-se escritor, que, até então, tinha sido reprimido pelo grande respeito quase religioso que devotara à literatura; no entanto, depois de constatar que se tem produzido e publicado "tanta bestagem em letra de forma" (Hilst, 2002, p.14), resolve escrever a sua própria.

No afã de produzir o seu próprio lixo literário, Crasso resolve rememorar e dar "forma" aos momentos marcantes da sua vida. Então nos deparamos com as mais absurdas e risíveis experiências, sejam elas sexuais ou literárias, com um incrível "laboratório" da linguagem, no qual, em um procedimento alquímico, veremos se fundir em meio ao

[...] romance memorialístico; diálogos soltos intercalados à história; imitação de certames poéticos à moda antiga [...]; apóstrofes aos leitores $[\ldots]$ apóstrofes aos órgãos sexuais [...]; contos e minicontos [...]; crônicas políticas; comentários etimológicos e eruditos; crítica literária [...] (Pécora, 2010, p.14)

Sem seguir normas ou receitas literárias tradicionais que delimitam e encerram em si mesmas os gêneros literários, nem "colocar fatos em uma sequência ortodoxa, arrumada", como no romance convencional, Hilda Hilst cria uma narrativa caótica, na qual os acontecimentos remorados por Crasso atropelam-se e tomam de assalto a página, sem seguir nenhuma sequência cronológica. Por mais que tentemos, não conseguiremos enquadrar Contos d'escárnio. Textos grotescos em um único gênero textual, pois o que nos é dado nessa prosa caótica é uma mistura enlouquecedora de gêneros.

Dessa produção literária prenhe de jogos de palavras ambíguos, de autorreflexão, de uma linguagem às vezes chula, às vezes erudita, de uma dicção próxima da oralidade que avança em uma prosa desvairada - entrecortada por poemas, críticas literárias, textos dramáticos e contos -, composta por Crasso e por outras vozes narrativas, um desafio se coloca para aqueles que se arriscam em sua 
tradução, fazendo-se necessário considerar diversas possibilidades tradutórias.

Na tarefa de tradução de Contos d'escárnio. Textos grotescos para o inglês, surge a tensão, sugerida por Rosemary Arrojo (2007), entre autor e tradutor. Como as tradutoras poderiam conduzir a tradução com autoridade suficiente para delinear as múltiplas possibilidades de interpretação e, ao mesmo tempo, manter-se fiéis às idiossincrasias das escolhas da autora? Em se tratando de uma autora até então pouco lida e pouco traduzida para o inglês, que alegou inúmeras vezes que queria ser "consumida", qual seria a postura ideal quando do ato tradutório? Optar por apaziguar os pontos de tensão da linguagem, facilitando, por assim dizer, a leitura da obra? Ou será que a tentativa, implícita nesse ato, de atenuar a prosa instável de uma escritora que pretende desafiar as expectativas do leitor seria muito arriscada?

Levando-se em conta as últimas inquietações, talvez encontremos uma opção mais adequada na abordagem radical proposta pelo teórico Lawrence Venuti, a qual prioriza o estranho e o exótico no texto traduzido em detrimento da perda do sentido que pode ter sido pretendido pela autora. $\mathrm{Ou}$, como propunha Friedrich Schleiermacher, no início do século XIX, o tradutor é responsável por trazer o elemento estrangeiro do texto à língua-alvo e de aproximar o leitor do mundo linguístico-cultural do autor.

Atualmente, os estudos de teoria da tradução constituem um campo prolífero dos estudos literários e vêm promovendo um intenso debate. Enquanto prática, a tradução vem sendo realizada desde os tempos mais remotos; no entanto, somente a partir do século XVIII o processo tradutório passa a ser sistematizado como estudo teórico, marcando o princípio da formulação de uma teoria da tradução. Durante séculos, vigoraram nesse campo do saber as ideias desenvolvidas pelo professor e teórico escocês Alexander Fraser Tytler (1747-1813), para quem a expressão "fidelidade ao original" - seja no que diz respeito ao conteúdo, ao estilo, à sintaxe, ao tom etc. - constituía um imperativo para a "boa" tradução. A noção de fidelidade permaneceu inabalável durante séculos e 
consolidou-se como uma forte premissa para os posteriores estudos de tradução.

Se entre os séculos XVIII e XIX, os poetas, sobretudo, ocupavam-se da tradução e das questões concernentes ao ato de traduzir, a partir do século XX os estudos de tradução passam a integrar o glorioso rol dos acadêmicos estudos linguísticos e literários. Desde então, as antigas questões sobre tradução passaram a ser reformuladas incessantemente e novas questões foram colocadas na pauta das discussões. Nas reflexões contemporâneas a respeito do tema, a arcaica noção de que uma tradução de qualidade deveria estar sempre relacionada a uma extrema fidelidade ao original perde o seu status quo e passa a ser pautada por outros parâmetros. Agora, não se trata de transferir identicamente significados e formas de uma língua para outra, e sim de recriar - num constante exercício de leitura, interpretação e reescrita - ambiências, estilos e formas a partir de uma relação íntima e complexa entre o texto de partida e o texto de chegada. Segundo Walter Benjamin (2008, p.69):

A tradução tende a expressar o mais íntimo relacionamento das línguas entre si. Ela própria não é capaz de revelar, nem é capaz de instituir essa relação oculta; pode, porém, apresentá-la, atualizando-a de maneira germinal ou intensiva.

Observamos que, tanto nas ciências como nas estéticas modernas e contemporâneas, um sem-número de autores, artistas e pensadores intercambiam antropofagicamente, e sem cessar, ideias, formas, temas, estilos e conceitos, de tal modo que, atualmente, não passamos pela leitura de um texto teórico, literário ou filosófico sem que reconheçamos, em alguma medida, traços de outro texto. Podemos avançar um pouco mais e dizer: raramente vemos uma obra de arte, seja ela pictórica, cinematográfica, teatral ou musical sem que reconheçamos texturas, temas, citações, traços, inter-relações, quaisquer que sejam elas, com outra forma artística. Poderíamos, inclusive, dizer que esse procedimento antropofágico é uma característica inerente à arte e à cultura, sobretudo na con- 
temporaneidade; portanto, hoje não seria mais possível conceber uma tradução pura e fiel ao original, já que o próprio "original" perdeu há algum tempo sua "aura”, sua "originalidade".

O que se deu, então, no campo da tradução de "textos criativos" foi uma crescente apologia a uma nova maneira de pensar a tradução que, seguindo os passos de Benjamin (2008), entendeu a tradução como uma forma que possui um caráter relativamente autônomo. Tratada como forma, por que não pensá-la como (re) criação, e não apenas como cópia? Os teóricos contemporâneos espargiram a noção de tradução e acrescentaram a ela conceitos como os de transcriação, plagiotropismo e transtextualização, criados por Haroldo de Campos, para quem:

[...] a tradução de textos criativos será sempre recriação ou criação paralela, autônoma porém recíproca. Quanto mais inçado de dificuldades esse texto, mais recriável, mais sedutor enquanto possibilidade aberta de recriação. Numa tradução dessa natureza não se traduz apenas o significado, traduz-se o próprio signo, ou seja, sua fisicalidade, sua materialidade mesma. (apud Diniz, 1999, p.35, grifo do autor)

Essa maneira de pensar o processo tradutório enobreceria a tarefa do tradutor, elevando-o ao posto de criador de uma outra e mesma obra ou, como bem colocou Benjamin (2008, p.75), “assim como a tradução é uma forma própria, também a tarefa do tradutor pode ser entendida como uma tarefa própria”. Dessa forma, na tarefa da tradução para inglês de Contos d'escárnio: Textos grotescos, tentamos colocar em prática as supracitadas teorias contemporâneas de tradução logo no próprio título da obra. Esse título estranho, além de ser "muito comprido" para a edição norte-americana, segundo os editores e tradutores norte-americanos consultados pelas autoras do presente artigo, contém a fantástica palavra marcada por uma longa tradição e sem vocábulo correspondente no inglês: escárnio. Uma palavra como "escárnio", que possui tão longa tradição nas letras lusófonas, ao ser traduzida para o inglês por mocking, derision, 
scorn etc., perde não apenas sua aura medieval, mas toda a referência a uma história da literatura satírica e erótica praticada desde os Cancioneiros galego-portugueses do século XIII até a literatura brasileira contemporânea.

O fato é que o mundo anglófono desconhece quase completamente as cantigas de escárnio e maldizer, gênero reproduzido pela Encyclopaedia Britannica com a frase tão pouco lírica de "songs of mockery and vilification". O título desse segundo livro da chamada tetralogia obscena não aponta para uma obra obscena qualquer, mas para uma obra destinada a um público sofisticado e culto, capaz de depreender a complexidade satírica inerente à junção do escárnio ao erótico e grotesco. Apesar de seu caráter erudito, o título não exclui um aspecto lúdico e absurdo, que, aliás, encontra-se na própria obra (outro volume do mesmo período produz um efeito semelhante: as poesias pornográficas e satíricas reunidas no livro Bufólicas faz uma referência cômica às Bucólicas de Virgílio, parodiando-o a partir da criação de um neologismo, procedimento linguístico bastante sofisticado).

O problema do título coincide com outro ainda maior, relativo ao tom geral dos Contos d'escárnio... Assim, não é de surpreender o fato de que o tom de escárnio da obra seja também uma das caraterísticas que mais nos desafiou durante a tradução. A própria Hilda Hilst se referia à tetralogia obscena como "uma literatura bem Brasil, uma linguagem barroca, muito suntuosa" (Francisco, 1991); assim, quanto mais suntuosa a linguagem, mais vertiginoso se torna o desafio da tradução.

Luciana Borges (2010, p.124) caracteriza a situação das obras obscenas como "um lugar de entremeio, um lugar de difícil acesso tanto ao leitor não iniciado, o antileitor de Hilda, quanto aos leitores-fãs da obra hilstiana”. Teoricamente, a tradução poderia se sentir em casa num "lugar de entremeio", frase que traz à memória a referida posição de Schleiermacher, assim como faz que nos lembremos das reflexões de Goethe, para quem, ao contrário da escola francesa, a tradução não deve domesticar o texto original, e sim enriquecer a língua, ampliando o gosto do público. Mas, como tantos tradutores 
sabem, na prática tal lugar pode ser desconfortável por ser pouco atraente para o mercado editorial, realidade semelhante àquela experienciada pela própria Hilda Hilst em sua relação com o mercado nacional. Se considerarmos que as traduções compreendem menos de 3\% do mercado editorial nos EUA, e as traduções literárias apenas uma pequena fração disso, é possível compreender que esse quadro não se refere apenas às vendas de ficção comercial, pois nem mesmo as pequenas editoras independentes, sem fins lucrativos, enfrentam o desafio de publicar uma prosa tão fora dos padrões comerciais.

Dessa maneira, de modo geral, levar ao público anglófono obras estrangeiras constitui em si uma tarefa hercúlea que pode se tornar ainda mais árdua quando a obra traduzida não se submete às normas jurídicas e morais do mercado norte-americano. Esse é o caso de Contos d'escárnios. Textos grotescos e dos demais romances da tetralogia obscena, pois esses textos complexos, irônicos e altamente eruditos muitas vezes são considerados "lixo" literário e pornografia barata. Consideremos uma já citada passagem de muita importância para o entendimento do tom do livro e das complicações que se apresentam em sua tradução. Crasso explica ao leitor ingênuo:

Resolvi escrever este livro porque ao longo da minha vida tenho lido tanto lixo que resolvi escrever o meu. Sempre sonhei ser escritor. Mas tinha tal respeito pela literatura que jamais ousei. Hoje, no entanto, todo mundo se diz escritor. E os outros, os que leem, também acham que os idiotas o são. É tanta bestagem em letra de forma que pensei, por que não posso escrever a minha? (Hilst, 2002, p.14)

Essa passagem, encontrada logo nas primeiras páginas do texto, expõe as dificuldades características. Aqui, na voz crassa do narrador, a prosa é, ao mesmo tempo, repetitiva ("resolvi [...], resolvi [...]”), desajeitada e pouco elegante. Os intricados níveis de ironia confrontam-se com uma declaração óbvia e pouco sutil, a de que o livro será trash. Contudo, a brincadeira complexa revela a típica ironia da autora e os leitores familiarizados com sua obra compreenderão que a narrativa de Crasso será pouco confiável. 
Mas como reagiria o leitor que ainda não tivesse se aventurado na leitura da obra hilstiana? Eis um ponto problemático da tradução para o inglês. Corre-se o risco de que a busca por uma maior aproximação do irônico e sofisticado procedimento hilstiano cause uma má impressão, afastando o leitor não iniciado, por considerar a tradução malfeita. Certamente, a compreensão do público leitor norte-americano não será imediata, pois mesmo no Brasil os primeiros livros da tetralogia obscena não foram bem recebidos pela crítica. No entanto, antes de chegar às mãos do público, o livro deverá passar pelas mãos da editora; assim, é necessário que elas sejam suficientemente atentas, sensíveis e "transgressoras" (ocorrências bastante raras) para reconhecer o mérito de um texto que, desde o início, se mostra desajeitado, com suas "tetas em riste", seus "suculentos melões" e seus "paus e picas" figurando em situações grotescas, contrapostas às mais nobres reflexões sobre a língua e a literatura: "É metafísica ou putaria das grossas?", questiona Crasso.

Eliane Robert Moraes (2003) caracterizou da seguinte maneira o desconforto particular que essa obra provoca:

Na qualidade de produção literária inferior, a pornografia é normalmente aceita ou, pelo menos, tolerada. Seu poder de transgressão é, nesse sentido, quase nulo. Na verdade, o texto erótico só consegue realmente escandalizar quando deixa de obedecer às leis do gênero menor, perturbando a zona de tolerância que cada cultura reserva às fabulações sobre o sexo.

Aparentemente, em sua época e em seu próprio país, Hilda Hilst encontrou dificuldades para explicar ao público, até mesmo para os leitores mais devotos, o conceito de um livro que recusa tanto as leis do gênero pornográfico quanto as da "alta" literatura. Em entrevista, a autora comentou essa dificuldade:

Fui muito ingênua. Achei que optando pela pornografia talvez chamasse a atenção. Mas sabe que aconteceu? Os que gostam da 
pornografia disseram que aquilo não era pornográfico. E os críticos "sérios" se decepcionaram comigo. (Hilst apud Castello, 1992)

Pode-se alegar que a decepção dos críticos demasiado "sérios" fosse o objetivo, nesse caso. Com sorte, a presença crescente de Hilda Hilst na cena literária norte-americana talvez constitua uma via de acesso ao entendimento de sua ironia mordaz.

É evidente, então, que a tradução tem uma responsabilidade enorme em recriar com bastante autoridade a linguagem, o tom e o humor do original. Mais uma vez, observa Moraes (2003):

Ao realizar um inventário da mercadoria literária mais estereotipada, o narrador coloca em questão o lixo cultural produzido no país, criticando a supremacia do best-seller. Mas sua visada, conclui o crítico, não se reduz a isso: o personagem vai além e faz da hegemonia da indústria cultural a condição de sua própria literatura, criando uma pornografia descontrolada, que excede as normas do mercado.

Caraterística desse excesso de "pornografia descontrolada" é a criação de um amplo vocabulário pornográfico. A língua portuguesa possui um vasto léxico correspondente aos atos sexuais e à genitália, muito maior e mais variado que a anglo-americana. Por exemplo, no inglês americano, os vocábulos em uso corrente para designar pênis ou vagina contam, no máximo, uns três ou quatro, para cada um.

Se, no nível mais elementar, existe uma grande distância entre o vocabulário sexual dos dois idiomas, é possível imaginar o desequilíbrio no caso da tetralogia obscena, com suas dezenas de apelidos para os órgãos sexuais, originados das mais diversas matizes culturais. Um bom exemplo disso é o quebra-cabeça que representa a palavra "cona", termo que substituindo vagina traz em si um sentido, ao mesmo tempo, vulgar e literário, e que foi resolvido de uma maneira relativamente satisfatória com o uso do termo cunny, palavra arcaica que também evoca o termo mais básico cunt. 
Houve, também, momentos virtuosos - como em qualquer projeto de tradução, muitos deles fruto de conversas longas e divertidas entre as tradutoras, e com colegas lusófonos e anglófonos - em que analisamos e comparamos as sutilezas dos dois léxicos pornográficos e literários. Desse modo, "Putaria das grossas", destacada da relevante frase "É metafísica ou putaria das grossas?", converteu-se, com muito esforço, em big fuck fest: "Is it metaphysical or a big fuck fest?"

O livro Contos d'escárnio. Textos grotescos termina com o último parágrafo de uma carta escrita por Crasso à sua amante:

Clódia: estive em Paris. Agora estou em Nova York. Encontrei um editor. Vou sair em inglês. O ganso está túmido de emoção. Segue endereço passagem numerário. Venha amanhã. Lave-se. (2002, p.114)

O caminho percorrido por Crasso no Brasil, passando em seguida por Paris e chegando a Nova York, reflete e parodia uma trajetória cliché bastante típica na literatura latino-americana, ao entrar no mercado literário mundial: consagrar-se em Paris (a capital de "The World Republic of Letters", segundo a tese, muito controversa, de Pascale Casanova, mas também muito em voga nos últimos anos no campo de literatura comparada), e ter a "honra" de ser recebido em Nova York e traduzido para o inglês. Levando-se em conta o grande escárnio de Hilda Hilst diante da poderosa e cínica máquina da indústria editorial global, podemos sugerir que a autora insinuava sardonicamente que uma tradução para o inglês, e a possível publicação naquela que seria a maior representante cultural dos EUA, seria uma recompensa justa pelo gênero de "bestagem" escrita por Crasso.

E se, por acaso, as autoras do presente ensaio conseguirem dizer, tal como Crasso, "encontramos um editor", a declaração "I'm coming out in English" adquirirá um outro nível de ironia. Nesse caso, o próximo grande desafio será o de apresentar a incorrigível Lory Lamby e seu Caderno rosa ao público norte-americano, que é a um só tempo tão pudico e tão obcecado pela sexualidade infantil. 


\section{Referências bibliográficas}

ARROJO, R. Oficina de tradução: a teoria na prática. 5.ed. São Paulo: Ática, 2007.

BENJAMIN, W. A tarefa-renúncia do tradutor. In: A tarefa do tradutor, de Walter Benjamin: quatro traduções para o português. Belo Horizonte: UFMG, 2008.

BORGES, L. Narrando a edição: escritores e editores na Trilogia obscena, de Hilda Hilst. Estudos de Literatura Brasileira Contemporânea, n.34, 2010.

DINIZ, T. F. N. Literatura e cinema: da semiótica à tradução cultural. Ouro Preto: UFOP, 1999.

HILST, H. Contos d'Escárnio. Textos Grotescos. São Paulo: Globo, 2002.

FRANCISCO, S. Hilda Hilst e seus autógrafos obscenos. Jornal do Brasil, Brasília, 24 out. 1991.

MEIZOZ, J. Postures Littéraires. Mises em scène modernes de l'auteur. Essai. Genéve: Slaktine Érudtion, 2007.

MAGNANI, G. A hora do poema/ Hilda Hilst. transgressiva, original e estonteantemente bela. Literatortura, 2 nov. 2012. Disponível em: $<$ http://literatortura.com/2012/11/a-hora-do-poema-hilda-hilst-transgressiva-original-e-estonteantemente-bela/>.

MORAES, E. R. A prosa degenerada. Folha de S.Paulo, São Paulo, 10 maio 2003.

PÉCORA, A. Nota do organizador. In: PÉCORA, A. (Org). Por que ler Hilda Hilst. São Paulo: Globo, 2010.

. (Org). Por que ler Hilda Hilst. São Paulo: Globo, 2010.

PURCENO, S. Ensaio de leitura. In: PÉCORA, A. (Org). Por que ler Hilda Hilst. São Paulo: Globo, 2010 . 


\section{SOBRE OS AUTORES}

Alcir Pécora - Professor de Literatura da Unicamp desde 1977, é autor de obras como Teatro do sacramento: a unidade teológico-retórico-política nos Sermões de Vieira (Edusp/Editora da Unicamp, 1994); Máquina de gêneros (Edusp, 2001); As excelências do governador (Companhia das Letras, 2002), em coautoria com Stuart Schwartz. É organizador de várias obras e estudos, entre eles, A arte de morrer do Padre Antonio Vieira (Nova Alexandria, 1994); Escritos históricos e políticos do Padre Vieira (Martins Fontes, 1995); Sermões I III (Hedra, 2000-2001); Índice das coisas mais notáveis (Hedra, 2010), Por que ler Hilda Hilst (Globo, 2010). Editor das Obras reunidas de Hilda Hilst e também das de Roberto Piva (Globo).

Alva Martínez Teixeiro - Professora auxiliar de Literatura e Cultura Brasileiras do Departamento de Literaturas Românicas da Universidade de Lisboa, é Doutora em Literatura Brasileira (2010), com a tese A obra literária de Hilda Hilst e a categoria do obsceno (Doutoramento Europeu e Prémio Extraordinário). Publicou as monografias Maktub - Da retórica na ficção de Raduan Nassar (2006); A pretensa nostalxia da autoridade - Unha interpretación parcelar d' O porco de pé de Vicente Risco (Prêmio "Ramón Piñeiro" de Ensaio, 2007); O herói incómodo - Utopia 
e pessimismo no teatro de Hilda Hilst (2009) e Nenhum vestígio de impureza - Da necessidade estética na ética e na poética de Sophia de Mello Breyner Andresen (2013), coordenando, com Dirk-Michael Heinnrich e Giancarlo de Aguiar, o volume Vicente e Dora Ferreira da Silva - Uma vocação poético-filosófica (2015). Em 2014, com o ensaio A linha de sombra de uma suspeita lição de zoologia - Do animal e do humano na narrativa de Lygia Fagundes Telles, obteve o "Prêmio Itamaraty - IV Concurso Internacional de Monografias" do Ministério das Relações Exteriores do Brasil.

Ana Chiara - Doutora em Letras pela PUC-RJ, Professora associada de Literatura Brasileira na Universidade do Estado do Rio de Janeiro desde 1995, dedica-se à pesquisa nos seguintes temas: corpo, sexualidade, memória. Autora dos livros Pedro Nava: um homem no limiar (EdUERJ, 2001) e Ensaios de possessão (Irrespiráveis) (Caetés, 2006), organizadora junto com Fátima Cristina Dias da Rocha dos livros Literatura brasileira em foco, volumes 2, 3, 4 e 5; co-organizadora também do livro Escritas do corpo (Caetés, 2011); autora de Angela Melim por Ana Chiara (EdUERJ, 2011), com Artur de Vargas Giorgi; Enxerto para uma vida feliz (Casa Doze, 2012) e do inédito Teoria em transe. Participa do GT ANPOLL de Literatura Comparada e Coordena o GPESq Corpo \& Experiência (http://gpcorpoexperiencia.blogspot.com/). Bolsista de Produtividade CNPq e Procientista da UERJ, desde 1995.

Éder Rodrigues - Escritor, dramaturgo e pesquisador teatral, é professor do Departamento de Artes da UNIR. Possuiu mestrado na área de Dramaturgia Contemporânea no Programa de Estudos Literários pela Universidade Federal de Minas Gerais (2010). Graduado/Licenciado em Artes Cênicas pela Escola de Belas Artes da Universidade Federal de Minas Gerais-UFMG (2007).

Elaine Cristina Cintra - Professora associada do Departamento de Letras do Centro de Ciências Aplicadas e Educação da 
Universidade Federal da Paraíba (UFPB), onde atua nas áreas de Teoria Literária e Literatura Brasileira, e docente do Programa de pós-graduação em Estudos Literários da Universidade Federal de Uberlândia (UFU). Mestre em Estudos Literários pela Unesp - Araraquara (1997) - e doutora em Teoria Literária pela Unesp - São José do Rio Preto (2005). Realizou, em 2012, estágio de pós-doutoramento na FFLCH-USP, desenvolvendo pesquisa, sob a supervisão da profa. dra. Viviana Bosi, sobre poesia contemporânea. Atua nas áreas de Teoria Literária, Literatura Brasileira, e desenvolve pesquisa relacionada às poesias brasileiras modernas e contemporâneas, possuindo artigos e capítulos de livros sobre o assunto. Em 2009, com a profa. dra. Enivalda Nunes e Freitas (UFU), organizou o livro Roteiro poético de Hilda Hilst, publicado pela Edufu - Editora da Universidade Federal de Uberlândia.

Eliane Robert Moraes - É professora de Literatura Brasileira na FFLCH da Universidade de São Paulo (USP), e pesquisadora do CNPq. Entre suas publicações destacam-se diversos ensaios sobre o imaginário erótico nas artes e na literatura, além da tradução da História do olho, de Georges Bataille (Cosac Naify). É autora, dentre outros, dos livros: O corpo impossivel - A decomposição da figura humana, de Lautréamont a Bataille (Iluminuras/Fapesp, 2002); Lições de Sade - Ensaios sobre a imaginação libertina (Iluminuras, 2006); e Perversos, amantes e outros trágicos (Iluminuras, 2013). Organizou a Antologia da poesia erótica brasileira (Ateliê, 2015) e atualmente desenvolve pesquisa sobre as figuras do excesso na prosa de ficção brasileira.

Higor Sampaio - Graduado em Letras (Português e Inglês) e mestre em Letras, com ênfase em Teoria da Literatura, pela Universidade Estadual Paulista "Júlio de Mesquita Filho", câmpus de São José do Rio Preto. Atualmente, é doutorando em Letras, com ênfase em Teoria da Literatura, pela mesma universidade, e conta com uma bolsa do CNPq para o desenvolvimento da sua pesquisa. 
Hsiao-Shih Lee - Doutora em Culturas Latino-americanas e Ibéricas pela Universidade de Stanford, onde leciona no Programa de Escrita e Retórica. Atualmente coedita com Marília Librandi-Rocha um livro sobre Haroldo de Campos e Octavio Paz.

Julia Powers - Tradutora em Nova York, doutoranda no curso de Literatura Comparada na Yale University. Publicou traduções literárias em várias revistas norte-americanas, incluindo Harper's Magazine, Lapham's Quarterly e Paris Review. Traduziu para o inglês, junto com Lívia Drummond, o livro Contos d'escárnio. Textos grotescos, do qual alguns fragmentos já foram publicados na revista Triple Canopy.

Livia Drummond - Possui licenciatura em História pela Universidade do Estado da Bahia. Graduanda no curso de Letras Vernáculas na Universidade Federal da Bahia, está vinculada ao grupo de pesquisa "O escritor e seu múltiplos: migrações", no qual foi bolsista CNPQ/PIBIC. Mestre pelo Programa de Pós-Graduação em Literatura e Cultura da Universidade Federal da Bahia e doutoranda nesse mesmo programa. Traduziu para o inglês, com Julia Powers, o livro Contos d'escárnio. Textos grotescos, de Hilda Hilst, do qual alguns fragmentos já foram publicados na revista literária americana Triple Canopy; traduziu para o português o texto La danse et l'absance d'oeuvre, de Frédéric Pouillaude, publicado pela revista Dança do Programa de Pós-graduação em Dança-UFBA.

Mechthild Blumberg - Doutora em Letras com tese sobre Hilda Hilst (pela Universidade de Bremen, Alemanha), mestre em Estudos Latino-americanos e Ciência das Religiões (pela Universidade Livre de Berlim), professora no Ensino Médio, docente na Universidade de Bremen e tradutora e intérprete juramentada. É autora de Spiritualität, Leidenschaft und obszöne Provokation: zur Dialektik zwischen Metaphysik und Körperlichkeit in Prosa und Lyrik der brasilianischen Autorin Hilda Hilst. Hamburg/Frankfurt a.M./Wien: Peter Lang, 2004; Zwischen Kontakt und Konflikt: Stand und Perspektiven der Postkolonialis- 
mus-Forschung. Org. Blumberg/Hamilton/Sandten, C. Trier: Wissenschaftlicher Verlag, 2006; Vielsprachiges Europa: zur Situation der regionalen Sprachen von der Iberischen Halbinsel bis zum Kaukasus. Org. Blumberg/Gugenberger. Hamburg/ Frankfurt a.M./Wien: Peter Lang, 2003.

Michel Riaudel - Professor do Departamento de Estudos Portugueses e Brasileiros da Universidade de Poitiers. Sua pesquisa volta-se para a literatura brasileira e as circulações literárias entre Brasil e França. Suas análises da poesia marginal carioca, do modernismo brasileiro, de Júlio Verne ou das metamorfoses do personagem Caramuru dialogam com questões de intertextualidade, tradução, translação, leitura, recepção, assim como as relações entre literatura e história. Tradutor de Ana Cristina Cesar, Hilda Hilst, Modesto Carone, José Almino, Milton Hatoum, entre outros.

Nilze Maria de Azeredo Reguera - Doutora em Letras pela Universidade Estadual Paulista "Júlio de Mesquita Filho", câmpus de São José do Rio Preto, com pós-doutoramento pela Faculdade de Filosofia, Letras e Ciências Humanas da USP, é docente da Unilago e autora de Clarice Lispector e a encenação da escritura (Editora Unesp, 2006) e de Hilda Hilst e o seu pendulear (Editora Unesp, 2013).

Sara Rojo - Possui doutorado em Literaturas Hispânicas - State University of New York at SUNY (1991), pós-doutorado em teatro italiano na Università degli Studi di Bologna (2000) e em Teatro chileno na Universidad de Chile (2007). Atualmente é Professora Associada IV da Universidade Federal de Minas Gerais, pesquisadora do CNPq. Tem experiência na área de Artes, com ênfase em Crítica, Teoria e Direção Teatral, atuando principalmente nos seguintes temas: América Latina, Teatro Latino-americano e Performance. Últimos livros publicados: La pulsión anárquica en el teatro latinoamericano: estudios teatrales en Brasil, Chile y Argentina, (Santiago: Editora Usach, 2010, com edição brasileira pela Editora Nandyala, 2011, de Belo Horizonte); Por 
uma crítica política da literatura: três perspectivas latino-americanas, em coautoria com G. Ravetti e G. Rojo (Nandyala, 2012).

Susanna Busato - Doutora em Letras pela Universidade Estadual Paulista "Júlio de Mesquita Filho", câmpus de São José do Rio Preto, e mestre em Comunicação e Semiótica pela Pontifícia Universidade Católica de São Paulo. Tem pós-doutorado em Linguística (Semiótica) pela Universidade de São Paulo. Atualmente é Professora Assistente-doutor da Área de Literatura Brasileira no Curso de Licenciatura em Letras (disciplinas de Poesia Brasileira I e II e Literatura Infantojuvenil); e no Curso de Pedagogia (disciplina de Literatura Infantil), na Universidade Estadual Paulista "Júlio de Mesquita Filho". Na pós-graduação ministra a disciplina de Vertentes e Expressões da Literatura Brasileira e Literatura Brasileira: linhas de força e tensão (com ênfase na poesia contemporânea). Tem três livros publicados em coautoria: Literatura e representações do eu (Editora Unesp, 2010); Figurações contemporâneas do espaço na literatura (Editora Unesp/Selo Cultura Acadêmica, 2010); e Fragmentos do contemporâneo: leituras (Editora Unesp/Selo Cultura Acadêmica, 2010). Tem um livro (poemas) de autoria publicado pela Editora Patuá, São Paulo, em 2013: Corpos em cena; e uma plaquete de poemas Papel de riscos, 2013, editada pelo Centro Cultural São Paulo (Secretaria da Cultura do Município da Cidade de São Paulo). 


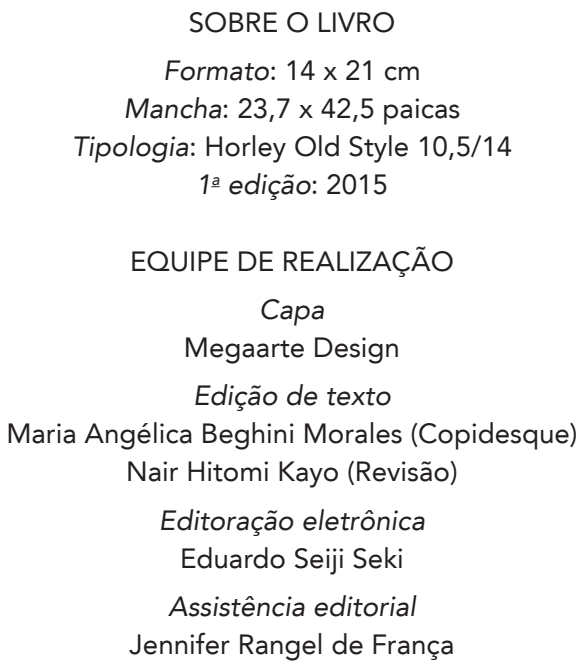

Formato: $14 \times 21 \mathrm{~cm}$

Mancha: $23,7 \times 42,5$ paicas

Tipologia: Horley Old Style 10,5/14

1ạ edição: 2015

EQUIPE DE REALIZAÇÃO

Capa

Megaarte Design

Edição de texto

Maria Angélica Beghini Morales (Copidesque)

Nair Hitomi Kayo (Revisão)

Editoração eletrônica

Eduardo Seiji Seki

Assistência editorial

Jennifer Rangel de França 